$$
\begin{gathered}
\text { UNIVERSIDADE DE BRASÍLIA } \\
\text { FACULDADE DE TECNOLOGIA } \\
\text { DEPARTAMENTO DE ENGENHARIA FLORESTAL }
\end{gathered}
$$

\title{
ÁRVORES NATIVAS DO CERRADO NA PASTAGEM: POR QUÊ? COMO? QUAIS?
}

ELISA PEREIRA BRUZIGUESSI

ORIENTADOR: DANIEL LUIS MASCIA VIEIRA

TESE DE DOUTORADO EM CIENCIAS FLORESTAIS

PUBLICAÇÃO: PPGEFL.TD

BRASÍLIA SETEMBRO -2016 
UNIVERSIDADE DE BRASÍLIA

FACULDADE DE TECNOLOGIA

DEPARTAMENTO DE ENGENHARIA FLORESTAL

PROGRAMA DE PÓS-GRADUAÇÃO EM CIÊNCIAS FLORESTAIS

\section{"ÁRVORES NATIVAS DO CERRADO NA PASTAGEM: POR QUÊ? COMO? QUAIS?"}

\section{ELISA PEREIRA BRUZIGUESSI}

TESE DE DOUTORADO SUBMETIDA AO PROGRAMA DE PÓSGRADUAÇÃO EM CIÊNCIAS FLORESTAIS, DO DEPARTAMENTO DE ENGENHARIA FLORESTAL, DA FACULDADE DE TECNOLOGIA DA UNIVERSIDADE DE BRASÍLIA, COMO PARTE DOS REQUISITOS NECESSÁRIOS PARA A OBTENÇÃO DO GRAU DE DOUTOR.

APROVADA POR:

Prof. Dr. DANIEL LUÍS MASCIA VIEIRA (Departamento de Engenharia Florestal - EFL/UnB);

(Orientador)

\section{RCCMeartius}

Profa. Dra. ROSANA DE CARYALHO CRISTO MARTINS (Departamento de Engenharia Florestal - EFL/Unßs);

(Examinador Interng)

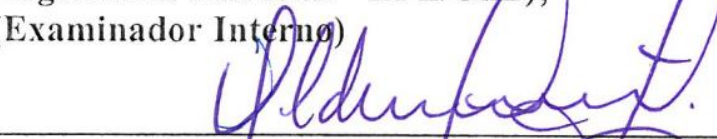

Prof. Dr. ALDICIR OSNI SCABKOT (Departamento de Engenharia Florestal $\mathrm{EFL} / \mathrm{UnB}$ );

(Examinador Vnterno)

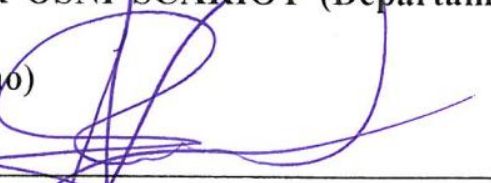

Dr. JOSÉ FELIPE RIßßLIRO (Empresa Brasileira de Pesquisa Agropecuária EMBRAPA);

(Examinador Externo)

Prof 'Dra. LUDIVINE ELOY COSTA PEREIRA (Centro de Desenvolvimento Sustentável - CDS/UnB);

(Examinadora Externa)

Prof ${ }^{\circ}$ Dr. ILDEU DOARES MARTINS (Departamento de Engenharia Florestal EFL/UnB).

(Examinador Suplente)

Brasília-DF, 29 de setembro de 2016. 


\section{FICHA CATALOGRÁFICA}

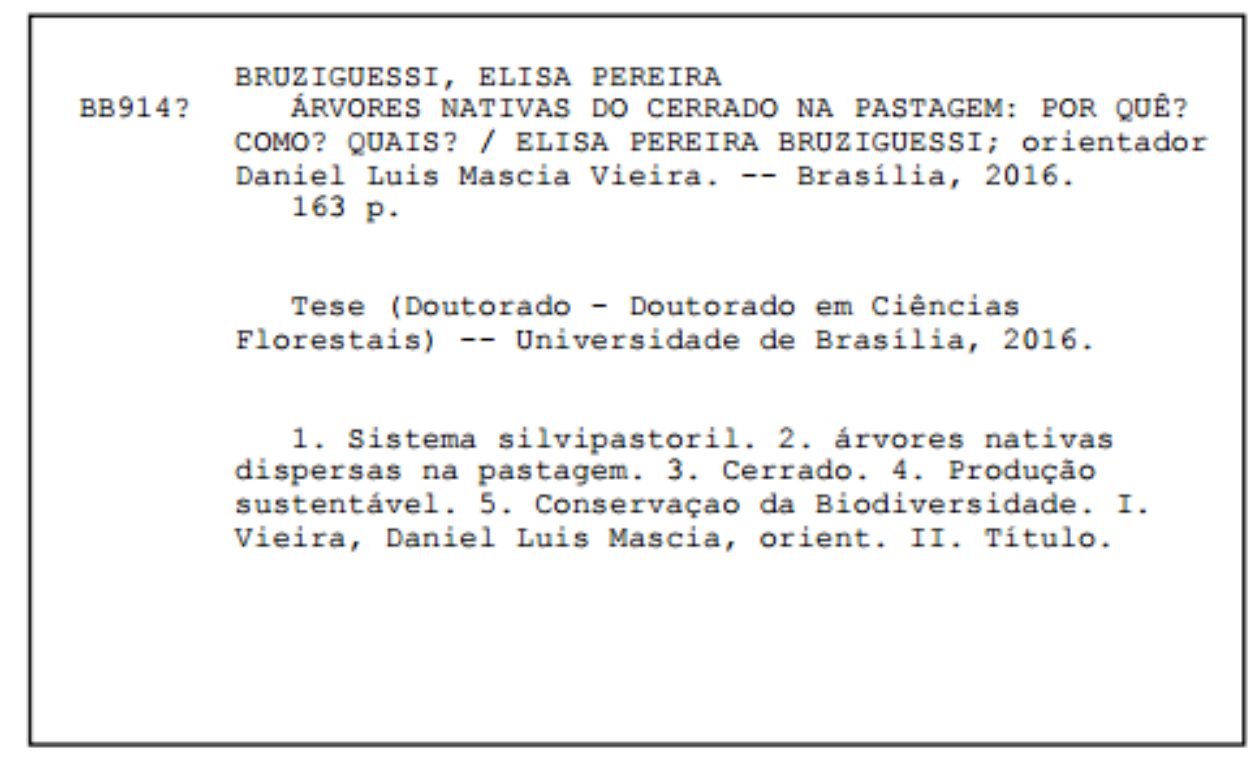

\section{REFERÊNCIA BIBLIOGRÁFICA}

BRUZIGUESSI, E. P. (2016). Árvores nativas do cerrado na pastagem: Por quê? Como? Quais? Tese de doutorado. Publicação PPGEFL. TD - 299/ 2015, Programa de Pós-Graduação em Ciências Florestais, Universidade de Brasília - UnB, Brasília, DF, $163 p$.

\section{CESSÃO DE DIREITOS}

AUTOR: Elisa Pereira Bruziguessi

TÍTULO: Árvores nativas do cerrado na pastagem: Por quê? Como? Quais?

GRAU: doutor

ANO: 2016

É concedida à Universidade de Brasília permissão para reproduzir cópias desta dissertação de mestrado e para emprestar ou vender tais cópias somente para propósitos acadêmicos e científicos. O autor reserva outros direitos de publicação e nenhuma parte dessa dissertação de mestrado pode ser reproduzida sem autorização por escrito do autor. 


\section{AGRADECIMENTOS}

Finalmente posso falar sem ter que citar, sem pensar mil vezes antes de errar... Quero agradecer:

Um dos sentimentos que mais permeia minha vida é a gratidão, não sei o que fiz pra merecer tanto! E neste trabalho não foi diferente, tantas pessoas gentis e prestativas foram aparecendo pelo caminho e ajudaram muito! Acredito que isso é coisa de Deus (ou da Deusa), não sei definir ao certo, e nem ouso tentar, só agradeço, todos os dias, mais e mais...e peço que continue me iluminando para que eu possa retribuir ao universo à altura!

Agradeço meu orientador, Daniel Vieira, pelo exemplo de dedicação e amor ao trabalho, por trabalhar de maneira tão séria e alegre, por sonhar alto, abrir horizontes e ser agregador de pessoas e idéias. Pela liberdade que sempre me deu pra poder pensar, fazer escolhas, mas sempre disponível pra orientar, estimular, instigar e ajudar. Por ter aceitado ser meu orientador na prática sem saber se isso seria de fato oficializado.

Sou muito grata a todos que me ajudaram em campo, foram muitas pessoas... mas isso não diminui minha gratidão por cada um. No meio de um turbilhão ainda ganhei mais duas amigas com quem muito me identifiquei, Belinha e Raíssa!

Agradeço ao Igor, meu companheiro de vida, de alma, de trabalho, por milhares de coisas, mas neste momento, em especial, por ter sido muito compreensivo com minha ausência, por ser pai tão presente e dedicado, o que ajudou a acalmar meu coração nos momentos longe.

Agradeço a minha filha Flora, que foi companheira íntima nesta jornada, me acompanhou em vários campos, desde a barriga, sempre boazinha! Naturalmente demandou muito minha atenção, mas aceitou minha ausência, por muitas vezes, de maneira tranquila e compreensiva, quando dizia palavras que se tornaram mágicas: "mamãe precisa ir trabalhar".

Agradeço minha amada família, em especial a minha mãe, que mesmo quando não podia se ofereceu pra ajudar e ajudou muito! Aos meus sogros que sempre solistas ficaram bastante com a Flora nesta reta final.

Sou grata ao IFB por ter me permitido ficar dois anos de licença para fazer este trabalho, certamente retribuirei à Instituição e aos estudantes este investimento. Agradeço o financiamento do projeto Bem Diverso GEF/PNUD/Embrapa nas coletas de 
campo, ao Projeto Biomas pelo financiamento do experimento do capítulo 4 e a CAPES pela bolsa prodoutoral. 
Eu sou um intelectual que não tem medo de ser amoroso, eu amo as gentes e amo o mundo. E é porque amo as pessoas e amo o mundo, que eu brigo para que a justiça social se implante antes da caridade.

\section{Paulo Freire}


Dedico esta tese aos pecuaristas do Cerrado que amam o que fazem, fazem com amor, que se preocupam com o bem estar dos animais, que gostam de estar próxima a natureza.

Aos estudiosos do Cerrado que em meio a um mar de informações, e lacunas do conhecimento, visam a conservação do natureza, mas não perdem o foco da busca pela diminuição da desigualdade social... 


\title{
RESUMO
}

\section{ÁRVORES NATIVAS DO CERRAdo NA PASTAGEM: POR QUÊ? COMO? QUAIS?}

\author{
Autor: Elisa Pereira Bruziguessi \\ Orientador: Daniel Luis Mascia Vieira \\ Programa de Pós-graduação em Ciências Florestais \\ Brasília, setembro de 2016
}

A pecuária é atividade de grande importância no mundo. Pastagens ocupam $70 \%$ das áreas agrícolas mundiais e são, ainda hoje, a principal causa do desmatamento nos países tropicais. O Brasil é o maior exportador de carne e o segundo maior produtor. $\mathrm{O}$ Cerrado possui a maior extensão de pastagens do país e contem aproximadamente metade do rebanho nacional. Diante da importância e dos impactos desta atividade é necessário implantar práticas pecuárias que comportem melhor utilização e gestão dos recursos naturais. Sistemas silvipastoris (SSP) representam uma dessas alternativas, eles podem aumentar a produtividade e bem-estar animal além de permitir a manutenção de serviços ambientais. A tese aborda SSPs com árvores nativas do cerrado lato senso, modalidade ainda pouco estudada. Por meio do estudo das diferentes configurações deste tipo de SSP e das espécies arbóreas que o compõe (ou podem compor), pretendese contribuir com o desafio de conciliar produção pecuária com produtos florestais, manutenção dos serviços ambientais, conservação da biodiversidade e da cultura local. Pretendeu-se conhecer a estrutura e a riqueza das árvores e seus regenerantes nesta modalidade de SSP. Foi realizado levantamento das árvores em 1 ha de SSP em cada uma das 47 áreas estudadas e dos regenerantes em $800 \mathrm{~m}^{2}$ em 16 áreas na zona central do bioma Cerrado. Realizou-se entrevistas com 51 pecuaristas para diagnosticar as motivações e os desafios na adoção desta modalidade de SSP e conhecer de que forma eles manejam seus sistemas e influenciam na dinâmica desta vegetação. Pode-se perceber uma diversidade de configurações dos SSP contendo poucas até muitas árvores nas pastagens (de 6 a 503 árvores /ha), podendo apresentar elevada riqueza (4 a 45 espécies/ha). Os pecuaristas que possuem alta renda e intensificação técnica, raramente possuem elevada densidade de árvores nas pastagens, mas ainda assim apresentam grande amplitude de densidade e riqueza de árvores em seus SSPs. Esta amplitude foi ainda maior entre os que possuem menor renda e intensificação técnica. Os entrevistados mostraram conhecer bem as espécies que compõe seu SSP, as selecionam baseado em um conjunto de utilidades que elas geram como madeira, frutas e benefícios ao capim e aos animais. As pastagens demostraram elevada capacidade de regeneração arbórea e uma distribuição dos diâmetros que parece garantir a perpetuação dos SSPs. Diante da elevada riqueza arbórea do bioma Cerrado torna-se necessário conhecer quais as espécies que apresentam maior potencial para comporem SSPs. Com este objetivo foi 
realizada a caracterização de 23 espécies nativas do cerrado lato senso, frequentes nos SSPs, com foco em atributos úteis, capazes de influenciar estes sistemas. Utilizou-se um conjunto de informações provenientes de levantamento em campo, entrevistas e revisão de literatura. Detalhou-se características da arquitetura da copa das árvores, seus potenciais de gerar produtos úteis e comerciáveis, a capacidade de fixar nitrogênio ao solo, de associar-se a micorrizas e de influenciar a cobertura de capim sob suas copas; além de fornecer forragem ou causar efeitos indesejáveis aos animais. Estas informações podem embasar e encorajar pecuaristas na escolha das árvores nativas para compor seus SSPs. Para os casos em que as pastagens perderam a capacidade de regenerar, os pecuaristas podem desejar plantar espécies nativas. Verificou-se a viabilidade da semeadura direta para esta finalidade com 10 espécies do cerrado sentido restrito, plantadas em uma pastagem em Planaltina-DF. Houve 12 repetições (linhas), em cada uma plantou-se 60 sementes de cada espécie. Das 7.200 sementes plantadas, 47,8\% emergiram e 26,5\% estavam vivas após 42 meses do plantio, o que representa 2,7 plantas por metro linear. Esta alta densidade permite a escolhas dos indivíduos mais vigorosos e bem posicionados de acordo com as preferencias dos pecuaristas. $\mathrm{O}$ crescimento das plantas até os 42 meses foi muito lento, atingindo média de $28 \mathrm{~cm}$ para Caryocar brasiliensis, espécie que apresentou crescimento mais rápido. Uma alternativa é o consórcio com culturas agrícolas para aproveitamento da área enquanto estas árvores crescem. Sistemas silvipastoris com árvores do cerrado merecem ser melhor estudados, estimulados e aperfeiçoados já que conciliam a produção e conservação.

Palavras Chave: Sistema silvipastoril, Cerrado, árvores dispersas, produção sustentável, conservação da biodiversidade 


\begin{abstract}
Livestock is an activity of great importance around the world. Pastures cover $70 \%$ of global agricultural areas and are still the main cause of deforestation in tropical countries. Brazil is the world's leading beef exporter and the second largest producer. The Brazilian Cerrado (Savannah) has the largest extension of pastures in the country, and it contains approximately half of the national livestock. In face of the importance and impacts of this activity, it is necessary to implement livestock practices that include a better use and management of natural resources. Silvopastoral systems (SPS) represent one of these practices; they can increase yield and animal well-being while maintaining environmental services. My thesis addresses SPSs with native trees from Cerrado sensu lato, which is still poorly studied. By studying the different settings of this type of SPS and the tree species that comprise it (or might comprise it), our aim is to contribute to the challenge of reconciling livestock production and forestry products, maintaining environmental services, and conserving biodiversity and local cultures. Our focus was on knowing the structure and richness of trees and their regenerants in this SPS. We conducted a survey of trees across 1 ha of SPS in each one of the 47 studied areas and of regenerants across $800 \mathrm{~m}^{2}$ in 16 areas in the central zone of the Cerrado biome. We also conducted interviews with 51 cattle ranchers to identify motivations and challenges in adopting this SPS and to know how they manage their systems and influence the dynamics of this vegetation. A diversity of SPS settings was observed, ranging from those containing few trees to those with many trees in the pastures (from 6 to 503 trees/ha), and they might account for high richness (4 to 45 species/ha). Cattle ranchers with high income and technical intensification rarely have high density of trees in their pastures; however, they still have a wide range of tree density and richness in their SPSs. This range was even wider among cattle ranchers with lower income and technical intensification. Interviewees showed very good knowledge of the species comprising their SPSs; they select species based on their set of uses, such as wood, fruits, and benefits to grass and to the animals. Pastures showed a high ability of tree regeneration and a diameter distribution that seems to ensure the perpetuation of SPSs. Due to the high tree richness in the Cerrado biome, it is necessary to know which species have a higher potential to comprise SPSs. Therefore, we characterized 23 native species of cerrado sensu lato that are frequent in SPSs, focusing on useful attributes which are capable of influencing such systems. The dataset used derived from the field survey, interviews, and literature review. We detailed canopy architectural characteristics, the potential of trees to yield useful and marketable products, their ability to fixate nitrogen in the soil, to associate to mycorrhizae, and to influence the grass cover under their canopies; as well as their ability to provide fodder or to cause undesirable effects to animals. These data might substantiate and encourage cattle ranchers in their choice of native trees to comprise their SPSs. For cases in which pastures have lost their ability to regenerate, cattle ranchers might want to plant native
\end{abstract}


species. We observed the viability of direct sowing for this purpose with 10 cerrado species strict sense, planted in a pasture in Planaltina-DF. There were 12 replicas (lines) and 60 seeds of each species were planted in each one. Of the 7,200 seeds planted, $47.8 \%$ emerged and $26.5 \%$ were alive 42 months after planting, which represents 2.7 plants per linear meter. This high density allows for choosing among the most vigorous and well-positioned individuals according to the preferences of cattle ranchers. The growth of plants up to 42 months was very slow, with Caryocar brasiliensis, the species with the fastest growth, reaching an average of $28 \mathrm{~cm}$. One alternative is combination with agricultural crops to make use of this area while trees are growing. Silvopastoral systems with cerrado trees deserve to be better studied, encouraged and perfected as they reconcile production and conservation.

key words: Silvopastoral systems, Cerrado, Scarett tree, Sustainable production, Biodiversity conservation 


\section{SUMÁRIO}

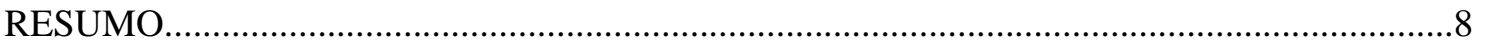

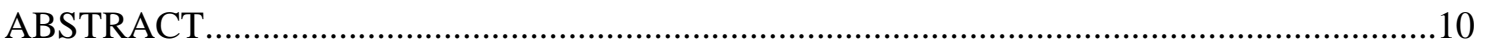

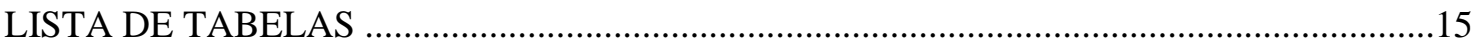

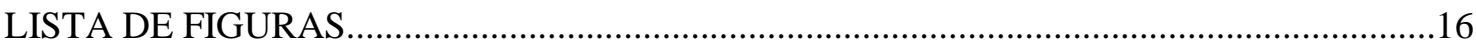

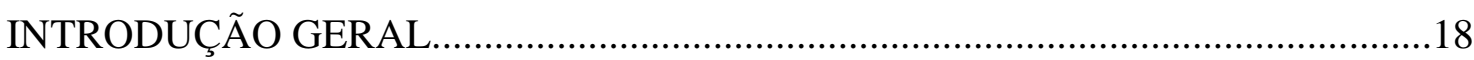

CAPÍTULO1- SISTEMAS SILVIPASTORIS COM ÁRVORES NATIVAS DISPERSAS: VANTAGENS, DESAFIOS E EXPERIÊNCIAS ...................................20

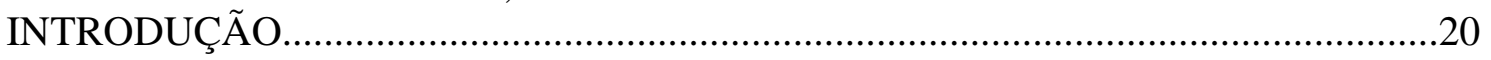

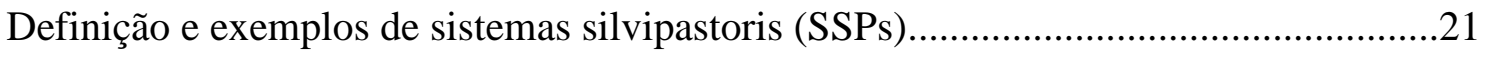

Complexidade dos SSP: competição x facilitação...................................................23

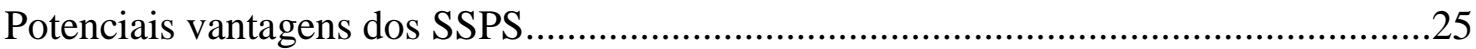

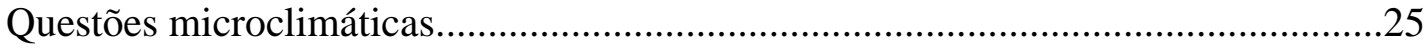

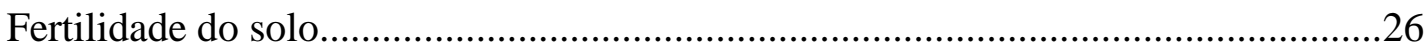

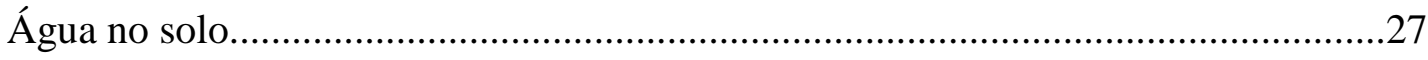

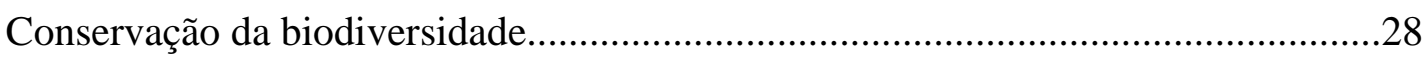

Aumento da qualidade e diversidade de alimento para o gado.............................29

Bem estar e aumento da produtividade animal.....................................................30

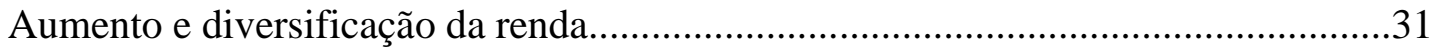

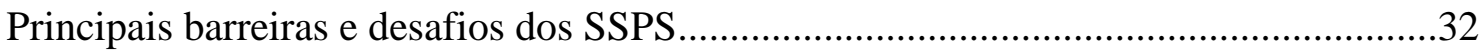

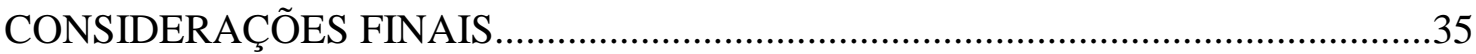

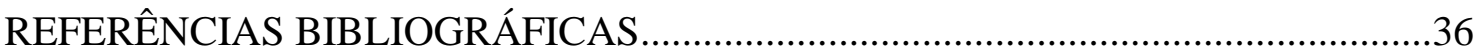

CAPITULO 2 - CARACTERIZAÇÃO DE PASTAGENS ARBORIZADAS COM ESPÉCIES NATIVAS NO CERRADO E DIAGNÓSTICO DOS SABERES DOS

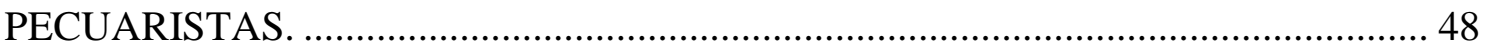

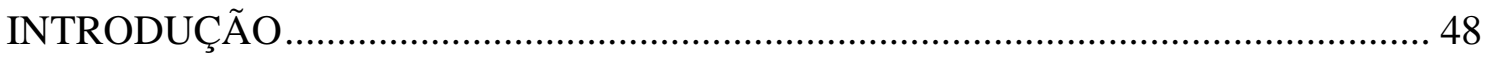

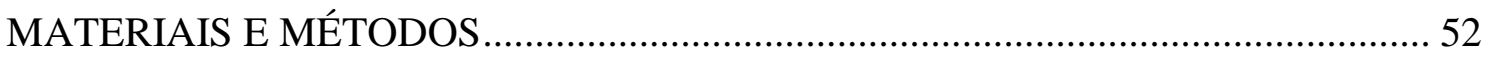

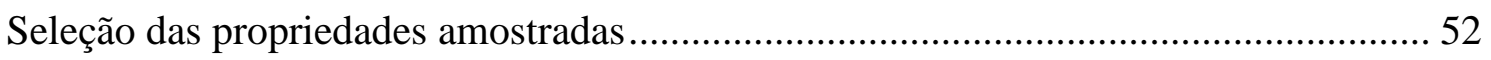

Compreensão dos sistemas por meio de entrevistas .................................................... 54

Levantamento da riqueza e estrutura das árvores e regenerantes...................................55

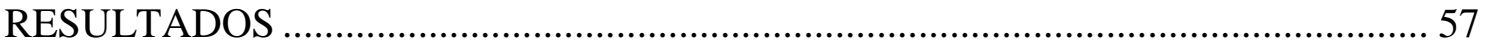




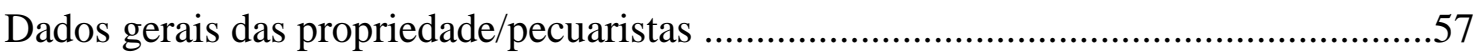

Estrutura e riqueza dos vegetação árborea em SSPs...................................................57

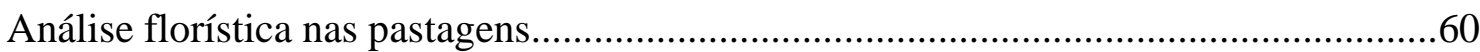

Relações do tipo de pecuarista com as árvores nas pastagens....................................62

Motivações e desafios para ter árvores nas pastagens...............................................67

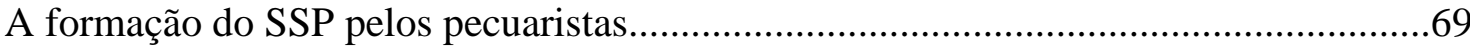

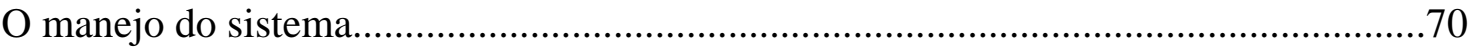

Interação das árvores com o gado e o capim segundo os pecuaristas............................72

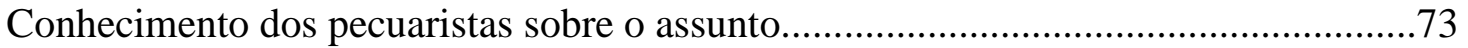

DISCUSSÃO

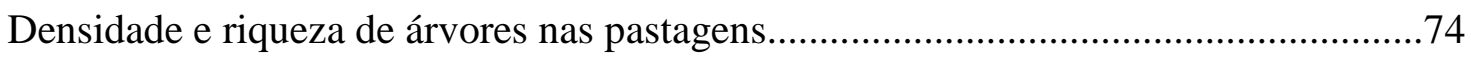

Relações do tipo de pecuarista com as árvores nas pastagens.....................................75

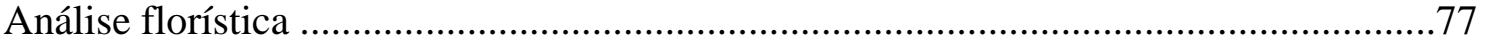

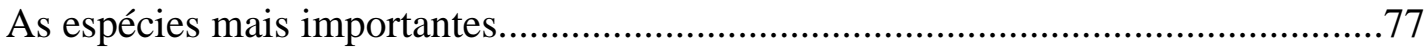

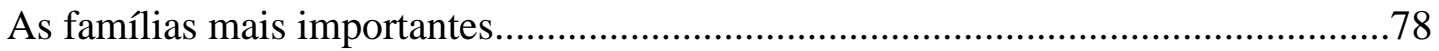

Distribuição diamétrica e manejo da regeneração.........................................................78

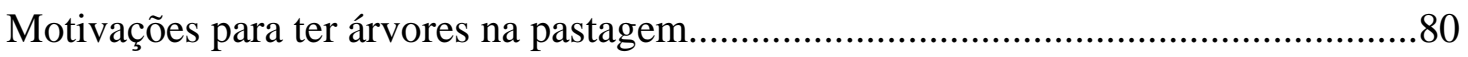

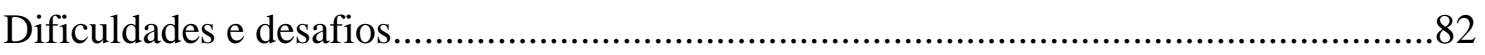

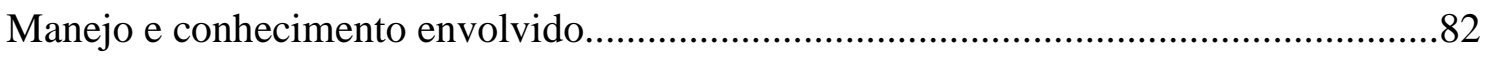

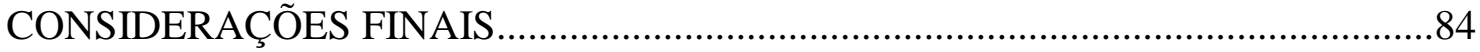

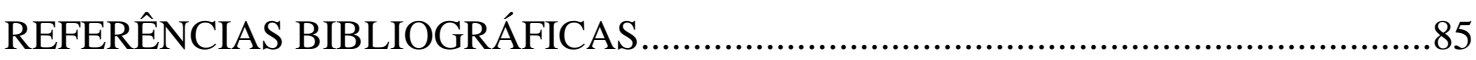

CAPÍTULO 3 - POTENCIAL DE ESPÉCIES ARBÓREAS DO CERRADO PARA COMPOREM SISTEMAS SILVIPASTORIS .......................................................... 93

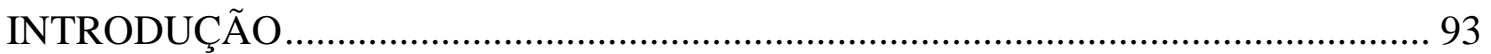

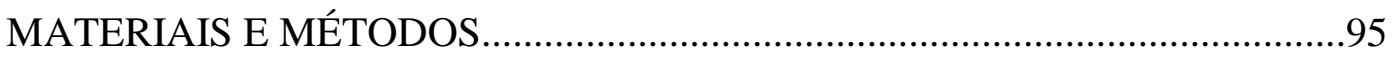

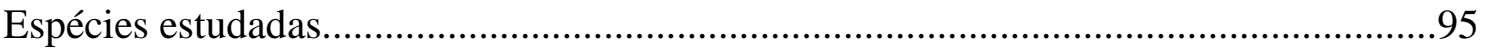

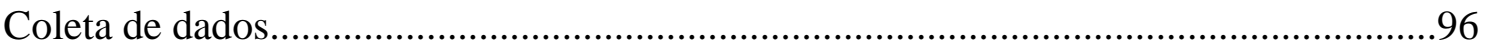

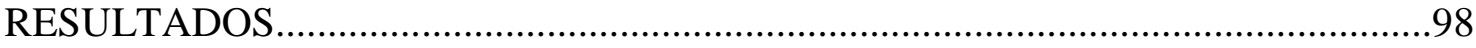

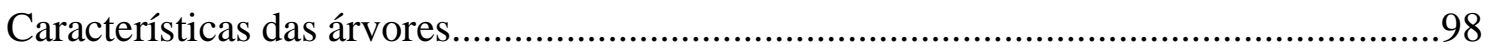

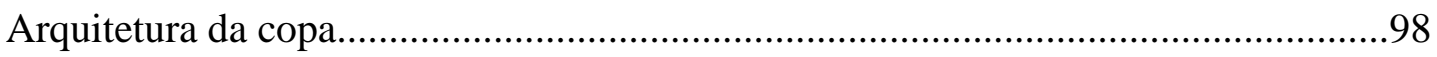

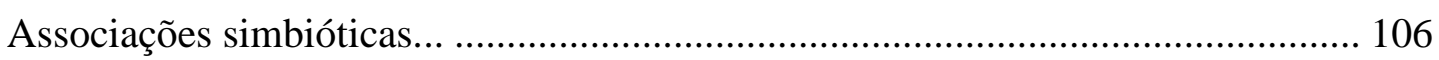

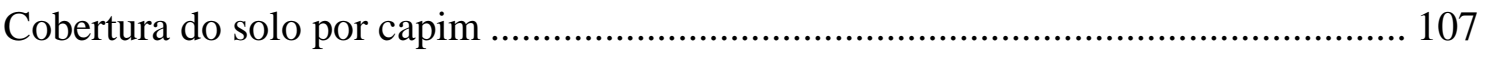

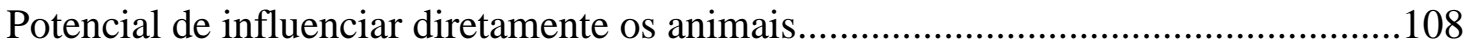

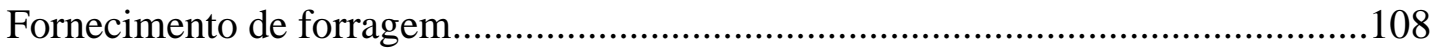


Efeitos indesejáveis das plantas nos animais 108

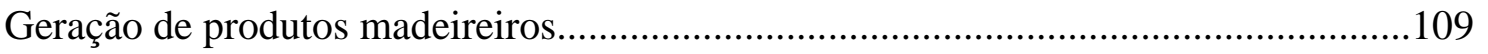

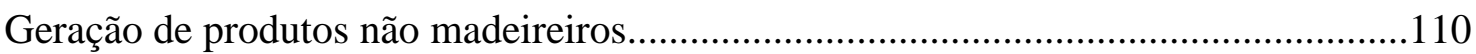

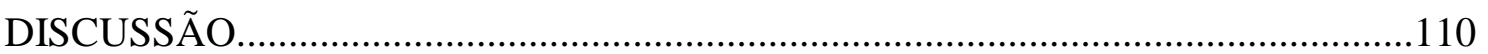

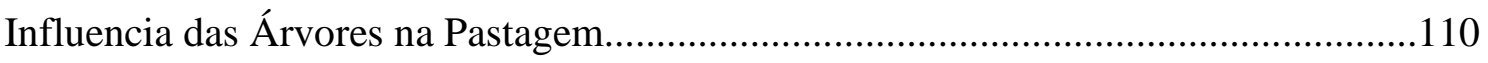

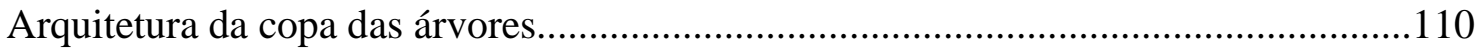

Densidade de árvores e sombreamento das pastagens..............................................114

Fixação de N e associação com micorrizas................................................................115

Árvores forrageiras e as que podem prejudiciais os animais....................................115

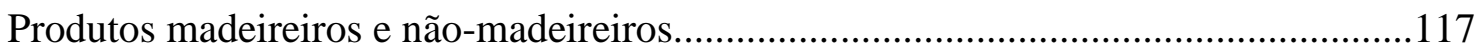

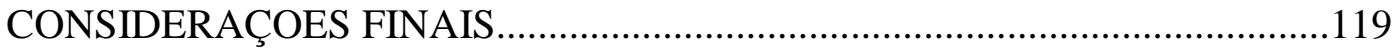

REFERENCIAS BIBLIOGRAFICAS...........................................,,,,,,,,.........120

CAPÍTULO 4 - SEMEADURA DIRETA DE ÁRVORES DE CERRADO PARA ESTABELECIMENTO DE SISTEMAS SILVIPASTORIS: EMERGÊNCIA, SOBREVIVÊNCIA E CRESCIMENTO AOS 42 MESES ........................................132

INTRODUÇÃO

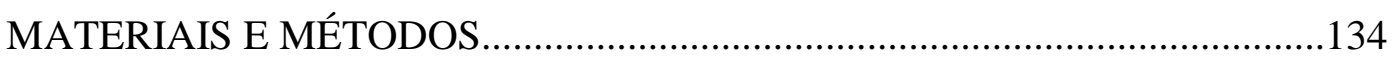

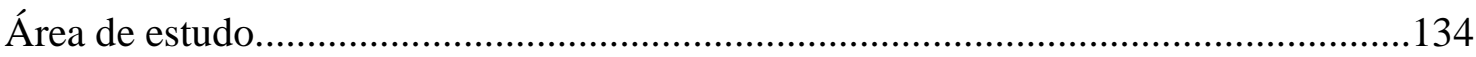

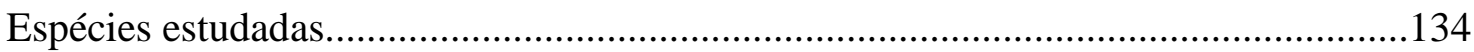

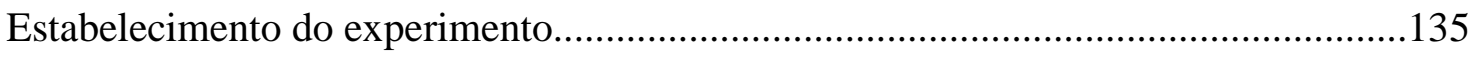

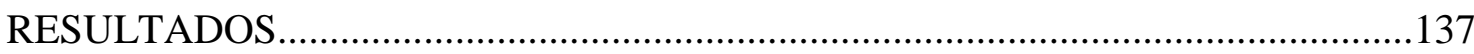

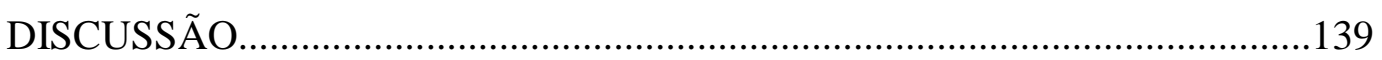

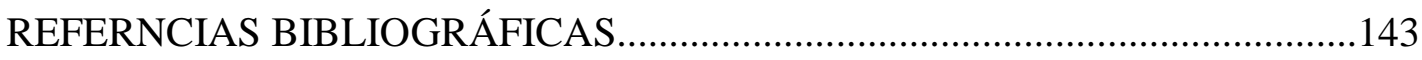

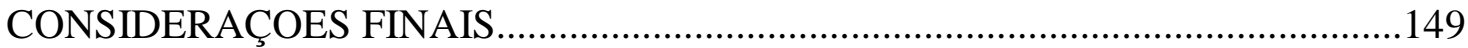

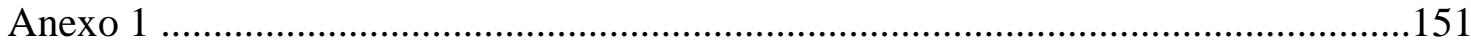

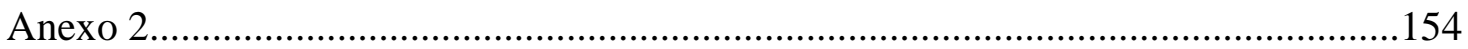

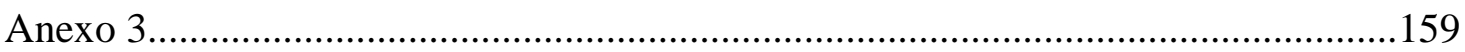




\section{LISTA DE TABELAS}

\section{Capítulo 2}

Tabela 1: Motivações dos 51 pecuaristas entrevistados para ter árvores na pastagem, dividas em categorias com o respectivo percentual do número total de pecuaristas que a citaram e a ordenação das respostas mias citadas.

Tabela 2: Critérios adotados pelos pecuaristas para seleção das árvores que mantem na pastagem durante o desmatamento seletivo do cerrado $(n=33)$...

Tabela 3: Argumentos citados pelo pecuarista para manter algumas rebrotas de árvores na pastagem durante o procedimento de "limpeza" das pastagens $(\mathrm{n}=29)$.

Tabela 4: Espécies citadas como prioritárias na seleção das regenerantes arbóreas ou as

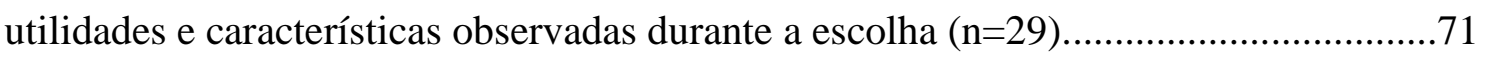

Tabela 5: Tipo de árvore que o gado demonstra ter preferencia para ficar em baixo segundo observações dos pecuaristas $(n=28)$. .72

Tabela 6: Características e espécies mencionadas pelos pecuaristas que influenciam positivamente o capim sob a copa das árvores $(n=27)$

Tabela 7: Características e espécies mencionadas pelos pecuaristas que influenciam negativamente o capim sob a copa das árvores $(n=23)$. .73

\section{Capítulo 3}

Tabela 1. Relação das características analisadas para as 23 espécies arbóreas estudas e a forma como cada dado será coletado. .98

Tabela 2: Caracterização de 23 espécies arbóreas nativas do cerrado segundo parâmetros de interesse para arborização de pastagens 100

\section{Capítulo 4}

Tabela 1- Espécies arbóreas nativas do Cerrado utilizadas em experimentos de semeadura direta para formar SSP realizados em Planaltina, DF. 134

Tabela 2: Valores de emergência em campo, geminação em laboratório e sobrevivência de dez espécies arbóreas nativas do Cerrado com valor econômico plantadas em área de pastagem para formar SSPs, em Planaltina, DF. 


\section{LISTA DE FIGURAS}

\section{Capítulo 2}

Figura 1: Representação esquemática da hipótese de que a densidade e riqueza de árvores nativas e regenerantes nas pastagens na zona core do Bioma Cerrado variam inversamente conforme o nível de intensificação técnica dos pecuaristas. .51 Figura 2: Localização das propriedades estudadas que possuem pastagens com árvores nativas na zona core do Cerrado.

Figura 3: Desenho esquemático que apresenta a metodologia de amostragem na coleta de dados sobre as espécies arbóreas e regenerantes presentes nas pastagens do Bioma Cerrado .56

Figura 4: Número de indivíduos arbóreos com DAB > $5 \mathrm{~cm}$ em um (01) ha de pastagem em cada uma das 47 propriedades estudadas. .58

Figura 5: Pastagens arborizadas com espécies nativas do cerrado levantadas no presente estudo com três gradientes de densidade de árvores .59

Figura 6: Riqueza arbóreas em um (01) ha de pastagem em cada uma das 47 propriedades estudadas.

Figura 7: Média da frequência das classes de diâmetro por ha, dos indivíduos inventariados em 47 pastagens arborizadas no Cerrado.

Figura 8: Índice de valor de importância das 20 principais espécies encontradas em pastagens arborizadas de 27 propriedades localizadas no Cerrado.

Figura 9: Representação das 20 espécies arbóreas regenerantes com maior somatório de densidade e frequência encontradas em pastagens arborizadas de 16 propriedades localizadas na área core do Cerrado.

Figura 10: Correlação entre a densidade e riqueza de árvores em pastagens do Cerrado com estimadores de renda dos proprietários.

Figura 11: Correlação entre a densidade e riqueza de regenerantes arbóreos em pastagens do Cerrado com estimadores do nível de intensificação técnica dos proprietários

Figura 12: Correlação entre a densidade e riqueza de árvores em pastagens do Cerrado com a nível de intensificação técnica das propriedades. 65

Figura 13: Correlação entre a densidade e riqueza de regenerantes arbóreos em pastagens do Cerrado com nível de intensificação técnica das propriedades. 66

Figura 14: Demonstração da não existência de houve correlação significativa (correlação de Pearson, $r=0,11 ; p=0,66$ ) entre a razão da densidade de árvores por animais e a diferença percentual de cobertura de capim sob a copa e a pleno sol.

Figura 15: Representação esquemática das diferentes densidades e riqueza de árvores nativas presentes em pastagens na zona core do Bioma Cerrado e sua relação (setas) coma renda do pecuarista e nível de intensificação técnica da pastagem. 


\section{Capítulo 3}

Figura 1: Localização das pastagens onde coletou-se dados das características de 23 espécies arbóreas nativas do cerrado lato sensu frequentes em pastagens, selecionadas para caracterização do potencial para arborizar pastagens.

Figura 2: Método para caracterizar a cobertura do solo no pasto a pleno sol e sob as árvores de 23 espécies nativas do cerrado lato sensu frequentes em pastagens, selecionadas para caracterização do potencial para arborizar pastagens

Figura 3: Característica da arquitetura de copa de 23 espécies arbóreas nativas do cerrado lato sensu, frequentes em pastagens, selecionadas para caracterização do potencial para arborizar pastagens

Figura 4 - Percentual médio da radiação fotossinteticamente ativa (\% RFA), durante o período chuvoso e seco, sob a copa de 23 espécies nativas do cerrado selecionadas para caracterização do potencial para arborizar pastagens. 106

Figura 5: Diferença da cobertura do solo por capim dentro e fora da área de influencia da copa das árvores medidos entre os meses de junho a setembro, considerando 20 pontos para cada individuo, com dez repetições.

107

\section{Capítulo 4}

Figura 1: Experimento de semeadura direta de árvores nativas do cerrado para formar SSP, localizado em Planaltina, DF. 137

Figura 2: Porcentagem de sementes que emergiram, se mantiveram vivas e morreram em experimento de semeadura direta com espécies de cerrado sentido restrito em pastagem localizada em Planaltina, DF. 138

Figura 3: Crescimento (altura, diâmetro e número de folhas) de oito espécies nativas do cerrado, plantadas por semeadura direta em área de pastagem localizada em Planaltina, DF. * A altura de Syagrus oleracea não foi medida devido sua gema apical estar muito próxima ao solo. 139 


\section{INTRODUÇÃO GERAL}

O presente trabalho trata de modalidade específica de sistema silvipastoril (SSP) formado por árvores nativas dispersas nas pastagens, com particular enfoque no bioma Cerrado. Esse sistema, presente em diferentes biomas no mundo, é formado pelo desmatamento seletivo, manejo da regeneração natural e raras vezes pelo plantio das espécies arbóreas. Por meio do estudo desse sistema e das espécies de árvores que o compõe (ou podem compor), pretende-se contribuir para auxiliar no desafio de conciliar produção pecuária com produtos florestais e manutenção dos serviços ambientais, conservação da biodiversidade e da cultura local. A tese está organizada em quatro capítulos. O primeiro é uma revisão bibliográfica sobre a importância da pecuária e seus impactos na sociedade, bem como a presença dos SSPs como alternativa para produção sustentável no contexto global, com ênfase no Cerrado. São caracterizados os sistemas de pastagens com árvores nativas dispersas, as relações de competição e facilitação entre gramíneas e árvores, bem como os diversos potenciais e gargalos. Este capítulo pretende compreender e ressaltar o caráter multidimensional e complexo do tipo de sistema estudado, e tornar clara, interessante e contextualizada a discussão que segue nos capítulos seguintes.

O capítulo 2 objetiva caracterizar e compreender as pastagens com árvores nativas dispersas presentes na zona central do Bioma Cerrado. Com esse propósito foi estudada a estrutura e a diversidade de árvores em pastagens de 47 propriedades rurais. Foram realizadas entrevistas semi-estruturadas com 51 pecuaristas para compreender suas motivações, dificuldades, práticas de manejo, preferências e percepções acerca do papel das árvores em suas pastagens. Este capítulo pretende contribuir para o entendimento de que pastagens não são apenas pastos de gramíneas africanas, mas sistemas socioecológicos com potencial de aproveitamento em programas de conservação da natureza e de serviços ecossistêmicos.

O capítulo 3 tem a premissa que o Cerrado possui espécies potenciais para serem incluídas nos SSPs e que elas são capazes de proporcionar serviços ambientais, contribuir com a produtividade das gramíneas e dos animais, além de gerar produtos comerciáveis, com a vantagem de serem adaptadas ao ecossistema propenso a incêndio, 
com baixa fertilidade e alta acidez natural e com forte sazonalidade. Porém, é necessário conhecer as características das espécies relacionadas aos SSP. Para tanto, foram selecionadas 23 espécies frequentes nas pastagens do Brasil Central e caracterizadas em relação aos atributos desejáveis da arborização de pastagens. Desta forma, almeja-se dar subsídios para que os produtores rurais possam escolher as espécies mais apropriadas para seus sistemas silvipastoris com maior embasamento, de acordo com objetivos pretendidos, preferências e possibilidades.

O capítulo 4 complementa a caracterização das espécies realizada no capítulo 3, enfoca 10 espécies arbóreas de usos múltiplos, nativas do Cerrado e parte da hipótese de que elas podem ser plantadas de modo eficiente por meio da semeadura direta para formar SSPs. Pretende-se conhecer, para cada uma dessas 10 espécies nativas plantadas, o potencial de desenvolvimento (emergência, estabelecimento e crescimento) a partir da semeadura direta. Pretende-se contribuir com o desenvolvimento de modelos de plantio de SSPs mais baratos e eficientes que incorporem a biodiversidade do Cerrado e gerem produtos úteis e rentáveis. 


\section{CAPITULO 1}

\section{SISTEMAS SILVIPASTORIS COM ÁRVORES NATIVAS DISPERSAS: VANTAGENS, DESAFIOS E EXPERIÊNCIAS}

\section{INTRODUÇÃO}

Pastagens cobrem $26 \%$ da superfície terrestre, equivalente a $70 \%$ das áreas agrícolas mundiais (FOLEY et al. 2011, FAOSTAT, 2013). O gado consome cerca de dois terços da matéria seca produzida pelas plantas terrestres cultivadas para fins alimentícios (WIRSENIUS, 2003). Previsões estimam que o consumo de carne e leite duplique até 2050 (HERRERO et al. 2009). Pastagens são, ainda hoje, a principal causa do desmatamento nos países tropicais, transformando grandes áreas com elevada biodiversidade em cultivos homogêneos (MURGUEITIO et al, 2011). O Brasil é o segundo maior produtor mundial de carne bovina e desde 2004 é o maior exportador (FAOSTAT, 2013). A criação de gado é praticada em todo o país, onde predomina o sistema extensivo. Nesse sistema, o gado pasteja em grandes áreas, exigindo baixos investimentos em insumos e mão de obra, comparado ao sistema intensivo, frequente em países desenvolvidos, em que o gado é confinado e recebe seu alimento rico em grãos (DIAS FILHO, 2014). É comum no Brasil que regiões deficientes em transporte, distantes do mercado consumidor e de baixo potencial agrícola sejam destinadas à pecuária, constituindo-se em atividade pioneira na ocupação e posse de grandes extensões de terra (DIAS-FILHO, 2011). O Cerrado apresenta $43 \%$ da sua vegetação nativa convertida em áreas de uso agropecuário, sendo $29,5 \%$ da área total do bioma ocupada com pastagens plantadas e $8,5 \%$ ocupada com o cultivo de culturas anuais, dentre elas soja e milho para consumo animal (BRASIL/MMA 2015). Além disso, apresenta a maior extensão de pastagens do país e é responsável por aproximadamente metade do rebanho nacional (LAPOLA, 2014; MMA/IBAMA 2011).

A degradação de pastagens é um fenômeno global, cerca de $20 \%$ das pastagens mundiais estão degradadas ou em processo de degradação (UNITED NATIONS ENVIRONMENT PROGRAMME, 2004). Nas pastagens degradadas há diminuição da matéria orgânica e nutrientes, compactação e erosão do solo, diminuição da 
produtividade, poluição das águas, além de outro problemas ligados à pecuária convencional, como a perda de habitat e ameaça a diversidade biológica, emissões de gases do efeito estufa (LARIOS E HERNANDEZ, 1992; DIAS-FILHO, 2011 GERBER et al., 2013; STEINFELD et al., 2006). O Cerrado enfrenta todos estes problemas, sendo que $24 \%$ de suas pastagens têm algum nível de degradação (DIAS FILHO, 2011). Áreas de expansão da fronteira agrícola tendem a ter maiores proporções de pastagens degradadas devido a abundancia relativa e gargalos de infra-estrutura (DIAS-FILHO, 2014). Portanto, é necessário identificar, avaliar e difundir práticas pecuárias que permitam melhor utilização e gestão dos recursos naturais. Sistemas silvipastoris (SSP) representam uma dessas alternativas, uma vez que, além de poder aumentar a produtividade e bem-estar animal, permitem a recuperação da fertilidade do solo, microclima e ciclo hidrológico, bem como o restabelecimento de parte da fauna e flora nativas (MCADAM et al., 2007).

Com esta revisão da literatura, pretendo identificar potenciais e desafios das pastagens arborizadas, especialmente aquelas com árvores nativas dispersas, além de compreender e ressaltar as inter-relações entre as dimensões ambientais, econômicas, sociais e culturais e a complexidade ${ }^{1}$ desses sistemas. Espero com esta revisão, contextualizar as discussões dos capítulos seguintes, assim como, aprimorar o entendimento sobre as práticas desse tipo de sistema de produção.

\section{Definição e exemplos de sistemas silvipastoris (SSPS)}

Dentre as diversas definições de sistemas silvipastoris, todas concordam que são a combinação de espécies arbóreas, plantas forrageiras e animais herbívoros, buscam a sustentabilidade das pastagens (nativas ou exóticas), e geram diversos produtos vegetais e animais, como madeira, carne e leite (CARVALHO et al., 1995). Tais sistemas representam uma forma de uso da terra em que atividades silviculturais e pecuárias são combinadas para gerar produção de fora complementar, por meio da interação dos seus componentes (GARCIA e COUTO, 1997). Os animais, a pastagem e as árvores interagem na mesma unidade produtiva sob uma gestão integral (SANCHEZ,

\footnotetext{
${ }^{1}$ Este conceito é compreendido nesta tese não como sinônimo de complicado, mas de acordo com a teoria da complexidade de Edgar Morin que diz que na busca da complexidade tentamos "escapar à alternativa entre o pensamento redutor que só vê os elementos e o pensamento globalista que apenas vê o todo" (MORIN, 1990, p.148). Complexus significa o que foi tecido junto. Há complexidade quando elementos diferentes são inseparáveis constitutivos do todo e há um tecido interdependente, interativo, e interretroativo entre o objeto de conhecimento, seu contexto e as partes entre si (MORIN, 2000, p.38).
} 
1999), que pode ser feita de maneira simultânea ou sucessiva (MURGUEITIO e IBRAHIM, 2008). Os elementos citados podem ser combinados de diversas maneiras, gerando diferentes tipos de sistemas silvipastoris, incluindo bancos de forragem, cultivo em aléias, plantações de árvores frutíferas e madeireiras, cercas vivas, quebra-ventos e árvores nativas dispersas em pastagens (ANDRADE et al., 2012; SANCHEZ, 2001; FRANKE e FURTADO, 2001). Os sistemas silvipastoris podem ser classificados em temporários, quando ocorre o pastoreio eventual no sub-bosque de povoamentos florestais, controlando a competição do capim com as árvores, e permanentes, quando planejados para que haja interações positivas e permanentes entre os animais, pastagem e árvores (ANDRADE et al., 2012; FRANK e FURTADO, 2001).

Em diferentes países, inclusive no Brasil, é frequente que no momento do desmatamento para estabelecimento das pastagens, os pecuaristas deixem árvores espalhadas para servir em diferentes funções nas fazendas (MUCHAGATA e BROWN, 2003, MIMENZA, 2011, GROVE e RACKHAM, 2001, CUBBAGE et al., 2012). São árvores de várias espécies, usos e estratos, encontradas em arranjos não sistemáticos, ou seja, dispersas na pastagem, em diferentes densidades (CASTILLO, 2013; , MUCHAGATA e BROWN, 2003). Além das árvores poderem ter sido deixadas no momento do desmatamento, elas podem ter surgido a partir da regeneração natural e serem mantidas pelo pecuarista, ou, mais raramente, terem sido plantadas (MIMENZA, 2007, ANDRADE et al, 2012). Nesse último caso, os plantios tendem a ter uma organização sistemática e com menor diversidade de espécies (MIMENZA, 2007, ANDRADE et al, 2012). Pode ocorrer das árvores serem oriundas das três alternativas acima em uma mesma pastagem. Exemplo deste sistema com árvores nativas dispersas nas pastagens tem-se as chamadas "dehesas" na Espanha, são sistemas seculares de pastagem com árvores de carvalho que fornecem sombra, forragem (frutos chamados "bolotas"), cortiça e lenha (GROVE e RACKHAM, 2001; JOFRE et al., 1988), além de agregaram novos valores como beleza cênica, recreação, caça, conservação cultural e ambiental (PULIDO et al., 2010; BIELING e KONOLD, 2014; PLIENINGER et al., 2015). Na Austrália, árvores de Eucalyptus em meio às pastagens predominam e representam um legado da antiga cobertura vegetal (LUNT, 2005). Este tipo de SSP também é notável nas paisagens da América Central, as quais possuem elevado número de espécies que servem para múltiplas funções, especialmente madeireiras e forrageiras (VILLANUEVA, et al. 2003; HARVEY, 2011; MIMENZA, 2011). Em regiões do 
Pampa Argentino, em clima semiárido, animais pastam sob árvores, predominantemente, de Prosopis caldenia, consumindo folhas e vagens muito nutritivas dessa espécie leguminosa (CUBBAGE et al., 2012).

Embora com peculiaridades, os exemplos de SSP em diferentes continentes têm em comum o histórico de formação a partir do desmatamento seletivo da vegetação nativa, com posterior manejo da regeneração natural. Além disso, parecem estar ameaçados por práticas agrícolas intensivas, ausência de políticas adequadas, baixa regeneração e morte de árvores velhas (BERGMEIER, et al., 2010). Este tipo sistema silvipastoril, com árvores nativas dispersas, também está presente no Brasil (ANDRADE, 2012; POTT e POTT, 1987). No Cerrado eles englobam vários arranjos que variam em um gradiente em relação à riqueza e densidade de espécies arbóreas, e capacidade de regeneração da vegetação, embora ainda sejam pouco estudados (DANIEL et al., 2001). No extremo de menor intensificação agronômica existem as pastagens nativas de cerrado, com capim nativo e grande diversidade e densidade de árvores nativas manejadas pelos produtores, nas quais o gado é criado solto em grandes áreas, sistema chamado de "solta". O sistema é predominantemente de uso comunal, com baixa carga animal, o gado se alimenta principalmente da vegetação nativa, sendo prática comum o uso do fogo para estimular as brotações (VALVERDE, 1967; LÚCIO, 2013). Atualmente este sistema persiste em poucos locais e com dificuldades devido as áreas comunais se tornarem mais raras e haver o cercamento das propriedades, além da proibição do uso do fogo. Os pecuaristas readaptaram este sistema utilizando-o em áreas comunais menores, conciliando o revezamento com pastagens cercadas com capins africanos plantados (LIMA, 2015; FERNANDES, 2011). Na presente tese foi observado (Capítulo 2) que sistemas de cultivo de pastagens com capins "africanos", com variados níveis de intensificação técnica, também conciliam árvores nativas em diferentes densidades, porém não está claro quais fatores influenciam a variação da densidade arbórea nas pastagens. Possivelmente esteja relacionada a diferentes históricos de uso e manejo do solo em cada propriedade, diferenças ambientais das regiões, além de variações socioeconômicas e culturais entre os pecuaristas.

\section{Complexidade dos SSPs: competição x facilitação}

Sistemas silvipastoris são complexos e os processos de interação entre os componentes capim, árvores e animais, são a chave para descrever o desempenho de 
todo o sistema. Interações ocorrem entre os diferentes componentes em termos de ocupação do espaço, verticalmente, horizontalmente, acima e abaixo do solo, e uso dos recursos, luz, água e nutrientes (ANDERSON e SINCLAIR, 1993). As interações entre animais, pastagem e árvores podem ser positivas ou negativas, e podem ocorrer simultaneamente (HOLMGREN et al., 1997). As árvores podem reduzir a produtividade das gramíneas por as sombrearem e por competirem por água e nutrientes, contudo, a competição não ocorre se a disponibilidade de recursos exceder a demanda exigida pelas gramíneas (BLASER et al., 2013; FERNANDEZ et al., 2002 ; MIMENZA, 2007). Além disso, o efeito das árvores pode ser positivo se aumentar a disponibilidade de recursos que podem ser limitantes, como nutrientes e água no caso de ambientes mais estressantes (CALLAWAY 1995; HOLMGREN et al., 1997; DOHN et al., 2013; BLASER et al., 2013; MOUSTAKAS et al., 2013).

Desta maneira, o impacto das árvores na produção e qualidade do pasto em SSP tem sido controverso. Resultados de maior e menor produção de pastagem sob copas de árvores foram encontrados em uma grande variedade de ecossistemas. Existe a tendência de maior facilitação da árvore ao capim em locais com condições ambientais extremas, e de maior competição sob condições mais amenas e favoráveis (DOHN et al., 2013). Plantas lenhosas com raízes profundas, podem melhorar a disponibilidade de água para as gramíneas sob suas copas, funcionando como "elevador hídrico" e reduzindo suas taxas de evapotranspiração (BRESHEARS et al., 1998; LUDWIG et al., 2004). Portanto, tendem a aumentar a produtividade das plantas sob suas copas em condições de estresse hídrico. Entretanto, as gramíneas podem diminuir a produtividade nos ambientes onde há maior umidade no solo, devido à diminuição da luminosidade por sombreamento das copas das árvores (DOHN et al., 2013).

A arquitetura das árvores também influencia as relações citadas acima. Árvores de maior porte tendem a aumentar o "elevador hidríco", a quantidade de nutrientes e incidência luminosa sob suas copas, comparativamente às árvores de menores dimensões, aumentando a produtividade das gramíneas sob elas em locais onde a restrição hídrica não é muito alta e desde que haja luz suficiente sob as copas. Por outro lado, em ambientes e épocas com severa restrição hídrica, o aumento da altura das árvores pode levar a maior penetração de luz e redução da umidade do solo, levando a diminuição da produção do capim (MOUSTAKAS, 2013; BLASER, 2013). Análise de diversos estudos em gradiente de precipitação encontrou que árvores fixadoras de 
nitrogênio aumentam ainda mais a produtividade do capim sob árvores altas em ambientes secos e atenuam efeitos negativos de árvores baixas (copas próximas ao solo) em ambientes mais úmidos (BLASER, 2013). A otimização das relações das árvores com as gramíneas depende da seleção das espécies forrageiras com maior tolerância à sombra, da escolha de árvores com arquitetura adequada, da otimização do posicionamento destas em relação ao sol e ao relevo, bem como, da utilização de técnicas de silvicultura para o manejo das copas e desbaste (ROZADOS-LORENZO et al., 2007; POLLOCK et al., 2009; FERNANDEZ et al. 2002).

O comportamento e o manejo do gado também influenciam a produtividade das gramíneas sob as árvores e em todo SSP (MOUSTAKAS et al., 2013). Pastagens com pouco ou nenhum sombreamento tendem a concentrar o gado em locais específicos por longos períodos (FERREIRA, 2010, ANDRADE et al., 2012). O gado descansa e rumina em locais próximos às porteiras, ao acesso à água ou sal, ou nas escassas sombras, causando concentração de fezes e excesso de compactação nestes locais (BRÁZ et al., 2003; FERREIRA, 2010). Desta mesma maneira, pastagens com poucas árvores promovem maior densidade de animais sob suas copas, o que compacta o solo e prejudica o capim neste local (DIAS-FILHO, 2006; ANDRADE et al., 2012). Por outro lado, árvores abundantes e bem distribuídas nos piquetes induzem maior homogeneidade na distribuição dos animais, das fezes e da fertilidade na pastagem, além de diminuir os efeitos da compactação do solo (KRUSCHEWSKY, 2009; FERREIRA, 2010). Esse aumento da fertilidade é significativo, já que 60-90\% dos nutrientes das plantas que o gado consome retornam para o solo por meio da urina e fezes (HAYNES e WILLIAMS, 1993).

\section{Potenciais vantagens dos SSPS}

\section{- Questões microclimáticas}

As árvores ajudam a estabilizar o microclima, protegendo os animais de condições extremas de calor ou frio (BALISCEI et al, 2013). Além disso, são capazes de fornecer uma série de benefícios microclimáticos também para gramíneas que estão crescendo sob suas copas, pois diminuem a temperatura do ar e do solo, especialmente em regiões secas e quentes (BELSKY et al., 1989). Isso causa diminuição da evaporação, mantendo maior umidade no solo e reduzindo o estresse hídrico das gramíneas. Geralmente, a cobertura da copa das árvores reduz as flutuações na 
transmissão de luz e na temperatura do ar. Portanto, forragens sob interferência de árvores apresentam menor variação sazonal (SILVA-PANDO et al., 2002) e ficam verdes por mais tempo (SANCHEZ, 2001) quando comparadas às forragens em áreas abertas.

Os SSPs diminuem a incidência de ventos fortes, reduzindo a retirada da umidade do ar e os danos físicos causados à planta forrageira. As folhas das gramíneas batem e friccionam sob vento forte, causando murchamento, dessecação, clorose e necrose nas folhas (NICODEMO et al., 2004). Se os ventos atingirem velocidades superiores a $6 \mathrm{~m} / \mathrm{s}$, a capacidade fotossintética das gramíneas forrageiras diminui (GREGORY, 1995). Por exemplo, em pastagens arborizadas no Paraná com Grevillea robusta houve redução da velocidade do vento em $26 \%$ no inverno, e de $61 \%$ no verão (PORFÍRIO-DA-SILVA et al., 1998). De forma semelhante, em outro SSP com faixas de árvores nativas no estado de São Paulo houve uma redução de $47 \%$ dos ventos quando comparados a áreas adjacentes sem árvores (PEZZOPANE et al., 2015).

\section{- $\quad$ Fertilidade do solo}

As condições ambientais mais amenas do solo e a interface solo/liteira contribuem para o aumento da atividade microbiológica, favorecendo a liberação mais rápida de nitratos, promovendo maior absorção de nutrientes pelas gramíneas e a produção do pasto (BELSKY, 1992; BERNARDINO e GARCIA, 2009). As árvores possuem raízes profundas que conseguem acessar água (CALDWELL e RICHARDS, 1989) e nutrientes nas camadas mais profundas do solo, indisponíveis às gramíneas de raízes superficiais. Com o processo de ciclagem de nutrientes estes elementos retornam às camadas superficiais, beneficiando o pasto (VETAAS, 1992; IBRAHIM et al., 2001).

Geralmente, o gradiente de fertilidade diminui a partir da base da árvore para além da sombra das copas (BELSKY, 1994). Árvores leguminosas melhoram a fertilidade do solo através da adição de nitrogênio por meio da sua fixação e por acumulação de serapilheira sob suas copas, particularmente na camada superficial ( 0 a $20 \mathrm{~cm})$. Solos em SSPs também costumam ter fósforo mais extraível $(\mathrm{P})$, maior disponibilidade de potássio (K) e de cálcio (Ca) (BELSKY 1989). O gado pastando nos piquetes recicla e redistribui a matéria orgânica e os nutrientes $(\mathrm{N}, \mathrm{P}, \mathrm{K}$ e $\mathrm{S})$ que estavam concentrados abaixo das árvores, através de esterco e da urina (MIMENZA, 2007). Por exemplo, abaixo da copa de duas espécies arbóreas nativas do Cerrado, baru 
(Dypterix alata) e pequi (Cariocar brasiliensis), o solo é mais rico em $\mathrm{N}, \mathrm{Ca}, \mathrm{Mg}, \mathrm{K}$, e C do que em área próxima a pleno sol (OLIVEIRA et al., 2005). Em outros SSPs também foi demonstrado o aumento da fertilidade do solo sob copas de árvores, como em SSP com leucena (Leucaena leucocephala) em relação ao solo de cerrado (MAFRA et al, 1998), sob a espécie nativa Stryphnodendron pulcherrimum na região Amazônica (ANDRADE et al., 2002), sob as copas de Ziziphus joazeiro e Prosopis juliflora, quando comparada com a área de capim sem árvores na Caatinga (MENEZES et al., 2002).

\section{- $\quad$ Água no solo}

Além da fertilidade e biologia do solo, as árvores alteram a dinâmica de umidade do solo sob sua copa, em função de três elementos: a) a precipitação que chega ao solo; b) o armazenamento de água no solo; e c) as perdas de água por evapotranspiração (JOFRE \& RAMBAL, 1988). Estudos demonstram que devido à interceptação da chuva pela copa das árvores, uma quantidade menor de água chega ao solo (THUROW,1987), mas a interceptação da chuva provavelmente está relacionada à intensidade da precipitação. Por exemplo, em savanas de Quercus nos Estados Unidos, chuvas abaixo de $50 \mathrm{~mm}$ causaram redução média de $41 \%$ da água que atingiu o solo sob as árvores, já as chuvas acima de 50 mm esta redução caiu para 26\% (KO e REICH, 1993). Porém, estes dados da precipitação sob as árvores podem estar subestimados pois não contabiliza a água que escorre pelo tronco.

Em contrapartida, o solo sob as árvores apresenta maior cobertura, macroporosidade e agregação e menor densidade e temperatura, o que faz com que a água seja armazenada com maior eficiência (CARVALHO et al., 2004; HERNANDÉZ, 1998). Além disso, a cobertura arbórea em SSPs, mais que a herbácea, contribui para incrementar a infiltração da água no solo, diminuindo o escorrimento superficial e o potencial de erosão hídrica (RÍOS et al., 2008; HOUGHTON, 1984). O sistema radicular das árvores contribui para minimizar deslizamentos de terra e erosões em áreas declivosas (HAWLEY e DYMOND, 1988).

Gramíneas forrageiras em consórcio com árvores sofrem menos as consequências da sazonalidade climática, apresentam coloração mais verde no período seco do ano, devido a maior quantidade de água retida do solo, influenciadas pelo componente arbóreo (FRANK e FURTADO, 2001). De acordo com as considerações 
acima, em estudo realizado em SSP no Cerrado, sob as árvores de Caryocar brasiliense e Dipteryx alata a umidade disponível para as gramíneas foi aproximadamente um mês superior ao das áreas adjacente sem árvores no final do período chuvoso (OLIVEIRA, 1999).

\section{- Conservação da biodiversidade}

Os SSPs com espécies arbóreas nativas do ecossistema local contribuem para conservação da biodiversidade (LOPEZ e IBRAHIM, 2007; NARANJO, 2003; HARVEY ET AL., 2006). A presença das árvores proporciona o aumento e diversidade de aves e insetos neste ambientes (CARDERNAS, 1999), inclusive de inimigos naturais de pragas das pastagens (KOLLER, 1988; AUAD et al., 2007). Sob suas copas são encontrados maiores valores em diversidade da fauna (DIAS et al., 2006; AUAD et al., 2007), incluindo o aumento de anelídeos que beneficiam o solo (LAZO et al., 2007).

Árvores nas pastagens podem reduzir o isolamento e fragmentação dos ecossistema naturais por tornar a paisagem mais permeável ao fluxo de animais e plantas nativas (HARVEY et al. 2005; BHAGWAT et al., 2008). Estas árvores fornecem abrigo para nidificação e poleiros para aves migratórias e residentes. Elas também servem como focos para a dispersão de sementes e recrutamento de plantas (HARVEY E HABER, 1999; OTERO- ARNAIZ et al., 1999). Estas pastagens arborizadas com espécies nativas podem contribuir na formação de corredores biológicos que tornam-se ainda mais importante diante das recentes estimativas das mudanças climáticas e a necessidade das espécies se dispersarem em direção a novos ambientes para sobreviverem (MANTYKA-PRINGLE, 2011). A formação destes corredores podem minimizar os efeitos sinérgicos da fragmentação dos ambientes e das mudanças climáticas visando a conservação da biodiversidade (MANTYKA-PRINGLE, 2011).

Um dos desafios relevantes na gestão da paisagem é saber pesar as decisões considerando as necessidades humanas a curto prazo e a manutenção da capacidade de prestação de serviços ecossistêmicos em longo prazo (FOLEY et al., 2005). Este debate recentemente foi enquadrado como um conflito entre duas abordagens: poupar terras ou geri-las de forma integrada com a paisagem (MATTISON E NORRIS, 2005). Porém, uma visão promissora da gestão da paisagem é reconhecer as contribuições complementares de grandes manchas da vegetação nativa e áreas com árvores dispersas 
nas propriedades rurais, esse pode ser um caminho para uma verdadeira integração entre conservação e produção sustentável (MANNING et al., 2006)

\section{- Aumento da qualidade e diversidade de alimento para o gado}

Em regiões com sazonalidade climática, durante a época seca, a pecuária que depende do pastoreio exclusivo de gramíneas naturais ou introduzidas tende a sofrer escassez de oferta de alimentos, pois o capim paralisa seu crescimento, o que acarreta diminuição de peso dos animais (MILIANI et al., 2008). Essa é a realidade de grande parte da pecuária no Cerrado. Portanto, em regiões com sazonalidade climática o potencial forrageiro de partes de uma espécie arbórea é uma característica muito útil aos SSPs (MAIA, 2004; MIMENZA 2007). Uma vantagem das pastagens com árvores dispersas é que normalmente apresentam grande diversidade de espécies arbóreas polivalentes que produzem em épocas distintas frutos e folhas com diferentes qualidades nutricionais favorecendo à produtividade do rebanho ao proporcionar fonte de alimentação mais estável durante a estação seca (MIMENZA, 2007). Quando há mais opções de forragem, os animais podem balancear ou variar sua dieta de acordo com seus requerimentos (SANCHEZ, 2001).

$\mathrm{Na}$ América Central, os pecuaristas conhecem o potencial forrageiro de muitas espécies nativas (MUNOZ et al., 2003; HARVEY \& IBRAHIM, 2003), o que tem sido suportado por pesquisas científicas (MIMENZA, 2007). É frequente que estas folhas e frutos contenham maior proteína bruta, digestibilidade da matéria seca e micronutrientes do que as gramíneas (DURR e RANGEL 2002; SANCHEZ, 2001). Por outro lado, gramíneas forrageiras também são frequentemente beneficiadas, diversos estudos em SSPs mostram parâmetros nutritivos superiores do capim sob sombreamento moderado, em comparação às gramíneas a pleno sol (PACIULLO et al., 2007; SOUSA et al, 2010; YAMAMOTO et al, 2007), além de se manterem verdes por mais tempo (SANCHEZ, 2001).

A utilização de forragens arbóreas na alimentação de bovinos é mais importante para os produtores com menor renda. Em um estudo realizado na Nicarágua, verificou-se que cerca de $47 \%$ dos produtores coletavam e preparavam a folhagem de árvores, no total de 30 espécies, para ser oferecida ao rebanho. Os pecuaristas creditam 
vantagens nessa prática, como a redução do número de animais doentes, menor mortalidade, bem como manutenção da produção de leite (ZAMORA et al., 2001). No Brasil, considerando sua alta biodiversidade, existem poucos estudos sobre o potencial forrageiro das árvores nativas para o gado bovino. Foram encontrados levantamentos exploratórios do consumo e valor forrageiro em pastagens nativas no Pantanal (SANTOS et al., 2002; 2003; POTT e POTT, 1987); Cerrado (CONCEIÇÃO, 2012), Mata Atlântica (SANTOS et al., 1998); na Caatinga estes estudos são mais frequentes porém com enfoque maior em caprinos e ovinos (COSTA et al., 2011; ZANINE et al., 2005; BAKKE et al., 2010). Também há pesquisas pontuais focadas em algumas espécies como o baru (Dipteryx alata) no Cerrado (OLIVEIRA, 1999), juazeiro (Ziziphus joazeiro) na Caatinga (PEREIRA et al., 2010) e baginha (Stryphnodendron guianense) na Amazônia (ANDRADE et al., 20002).

\section{- Bem estar e aumento da produtividade animal}

Ao estabilizar o microclima, as árvores protegem os animais de condições extremas de calor ou frio, aliviando o estresse térmico, com efeitos positivos no que se refere à produtividade do rebanho (BALISCEI et al., 2013). O maior conforto térmico implica no aumento da produtividade, ganho de peso (RESTREPO, 2002; OLIVARES e CARO, 1998), reprodução (CARVALHO, 1998), e produção de leite (BETANCOURT et al., 2003).

Os bovinos, respondem a alterações no ambiente térmico com modificações não somente fisiológicas ou funcionais, mas também comportamentais, com o objetivo de maximizar a dissipação de calor (MCDOWELL, 1972 apud FERREIRA, 2010). Este último autor observou que o tempo de pastejo correlaciona-se negativamente com a temperatura ambiente, e que animais sem acesso à sombra diminuem o tempo de ruminação, tempo em decúbito e consumem mais água, corroborando à hipótese de que fatores climáticos afetam o comportamento ingestivo de bovinos. Outro estudo verificou redução de $49 \%$ e $55 \%$ na digestibilidade de matéria seca e proteína bruta, respectivamente, dos animais estressados, comparado aos animais mantidos em conforto térmico (PASSINI et al., 2009).

Se o gado não consegue dissipar o calor excedente (pela pele, por evaporação, condução, radiação ou convecção) sua temperatura corporal aumenta acima dos valores fisiológicos normais e o animal passa a uma condição de estresse calórico, que contribui 
com a baixa produtividade (NÓBREGA et al., 2011). Esse estresse pode afetar o sistema imunológico do animal e torná-lo mais suscetível a doenças. Um dos principais recursos utilizados por bovinos em pasto, na tentativa de amenizar temperaturas elevadas e alta radiação, é a busca por sombra, principalmente nas horas mais quentes do dia (GLASER, 2008). A redução da carga de calor radiante pode ser superior a $30 \%$ na sombra (BLACKSHAW e BLACKSHAW, 1994). Entretanto, os tipos de sombra, de acordo com a espécie arbórea e conformação da copa, podem ser mais ou menos adequadas ou "desejáveis" para sombreamento de pastagens (DA SILVA, 2006)

É recomendável que haja árvores para ofertar sombra para todos os animais ao mesmo tempo (MALAFAIA et al. 2011). Vacas expostas à sombra natural têm aumento na produção de leite, comparadas àquelas mantidas a sol pleno (YAMAMOTO et al, 2007; RESTREPO, 2002; GUISELINI et al., 1999). Outro estudo observou que animais que vivem em locais com acesso à sombra têm frequência respiratória e temperatura corporal mais baixas, produzem $11 \%$ mais leite, apresentam taxa de concepção $19 \%$ maior e incidência de mastite 10\% menor que animais sem sombra (DE MOURA et al., 2003). O sombreamento exerce efeito positivo na redução do estresse térmico em bovinos de raças europeus e zebuínos, independente da última raça ser mais tolerantes ao calor (GAUGHAN et al., 2009).

Mesmo que a produção de capim em pleno sol seja similar ou até maior do que sob as copas das árvores, frequentemente, os dados de produção animal são superiores, visto que a menor produção de capim é compensada pelo benefício do conforto térmico dos animais (VILLANUEVA, 2008).

\section{- Aumento e diversificação da renda}

Além dos benefícios da maior produtividade animal, o sistema torna-se mais rentável pela possibilidade da comercialização da madeira e produtos não madeireiros oriundos das árvores. Principalmente nos SSPs com árvores dispersas, as espécies com potencial madeireiro são usadas diversas vezes para atender demandas internas da fazenda, como na utilização de construções, confecção de cercas ou até mesmo comercializadas nos arredores por meio de troca ou venda entre vizinhos (HARVEY, 2011). Dessa forma também ocorre com as árvores frutíferas, as quais são consumidas pelos animais e pelas famílias que vivem nas proximidades. Há também o potencial referente a exploração da produção de mel e pólen (PULIDO, et al., 2010). Todos esses 
produtos contribuem economicamente para renda familiar, seja por meio da venda de produtos, seja por evitar gastos externos.

Outro potencial fonte de renda, principalmente para os SSPs biodiversos, é o pagamento por serviços ecossistêmicos (PETERS et al., 2013; SMITH e SHERR, 2002). Esse mecanismo já está em vigor em diversos países, como na Costa Rica, pioneira nesse tipo de programa (PAGIOLA, 2008). Nesse país, no estado de Esparza, os pecuaristas se mostraram satisfeitos com os benefícios dos SSPs, como resultado, as pastagens degradadas diminuíram 14\%, as pastagens com árvores aumentaram 39\% e consequentemente a produtividade dos SSPs aumentou (CASASOLA, 2009).

Conforme descrito anteriormente as vantagens dos SSPs estão relacionadas ao aumento da rentabilidade do sistema, já que geram produtos comerciáveis provenientes das árvores, aumentam a produtividade do gado (mais carne e leite para vender), melhoram o solo (economia em fertilizantes), aumentam a qualidade e diversidade de alimentos para os animais (economia com o compra e transporte de forragem) e tornam o sistema menos suscetível a pragas e doenças com menores perdas e economia em pesticidas (SANCHEZ, 2001). Entretanto, como vários desses fatores geram economia de gastos e não a geração de renda diretamente, eles tendem a ser negligenciados, seus valores monetários são muitas vezes invisibilizados por falta de valor de mercado (COSTA, 2012). Assim, torna-se necessário mensurar e divulgar estes valores. Desta forma, estudos na área da economia ecológica podem contribuir para superar esse desafio (ANDRADE, 2008; CAVALCANTI, 2010).

\section{Principais barreiras e desafios dos SSPS}

Apesar dos diversos benefícios descritos acima, a adoção dos SSPs ainda é limitada no Brasil (DIAS-FILHO e FERREIRA, 2007) e em diversos países (DAGANG E NAIR, 2003). A maior parte das áreas destinadas à pecuária no Brasil permanece com pastagem extensiva e cobertura arbórea mínima (PAGIOLA et al., 2007), apesar de inúmeros experimentos com plantios de espécies arbóreas de rápido crescimento nas pastagens apresentarem resultados positivos nesse país (BUNGENSTAB, 2012). A discrepância entre as evidências técnicas e a realidade prática sugere a existência de barreiras que estariam dificultando a adoção mais ampla dessa tecnologia pelos produtores (DIAS-FILHO e FERREIRA, 2007). Portanto, é preciso identificar essas barreiras e compreender os riscos à adoção de diferentes modalidades de SSPs. Porém 
faltam estudos que analisem as dificuldades específicas dos SSP conduzidos por meio do desmatamento seletivo e da regeneração natural no Brasil; portanto, as discussões a seguir são mais voltadas aos SSP que envolvem o plantio de árvores.

Um entrave ao plantio dos SSPs em áreas já desmatadas e com baixa regeneração natural é o alto investimento necessário em capital, trabalho e tempo relacionados ao plantio e manutenção das espécies arbóreas (DAGANG E NAIR, 2003). A falta de capacidade de investimento, ausência de incentivos econômicos e o intervalo de tempo entre o investimento e o retorno foram os motivos mais comuns para não se adotar SSP em um estudo realizado na Colômbia (CALLE et al, 2009). Além disso, podem existir custos de oportunidade resultantes do fechamento temporário das áreas onde as árvores são plantadas até atingirem um tamanho em que o gado não provoque mortalidade (PAGIOLA et al., 2007; DAGANG e NAIR, 2003).

Estudos demonstram que o produtor está mais propenso a adoção de sistema de produção com baixos investimentos que garanta estabilidade de renda, do que sistemas com menor estabilidade e maior probabilidade de lucro. Essa situação se aplica a locais onde predominam o monocultivo de gramíneas e que exigem, para formar SSPs, o plantio de espécies arbórea (DIAS-FILHO e FERREIRA, 2007, COSTA, et al 2012). Outras justificativas são uma possível indução aos monocultivos pelas indústrias de equipamentos e insumos, geralmente especializadas, a quem interessa ter uma clientela também especializada; falta de iniciativa e habilidades empreendedoras nos produtores; importância secundária dada às questões sociais e ambientais, possivelmente, pela falta de uma remuneração direta pelas mesmas (COSTA, et al 2012).

Os SSPs, em que as árvores foram plantadas, comparados aos sistemas convencionais de pastejo, exigem maiores investimentos em tempo, mão-de-obra e infraestrutura, maior conhecimento tecnológico e decisões de manejo por parte dos produtores (DIAS-FILHO, FERREIRA, 2007; LEE, 2005). O acesso à assistência técnica especializada para lidar com a complexidade do sistema é determinante para que pecuaristas adotem SSPs (PATTANAYAK et al., 2003). Há escassez de técnicos extensionistas e falta de conhecimento dos técnicos existentes sobre práticas produtivas mais sustentáveis (CAPORAL e COSTABEBER, 2004) como os SSP.

As motivações pelas quais os produtores decidem criar gado explicam, em parte, sua capacidade e vontade de adotar SSP. Produtores podem criar gado como uma 
alternativa de fonte de renda, uma reserva para emergências, e como principal meio de vida. O produtor que cria gado para necessidades emergenciais provavelmente não está disposto a investir no plantio de SSP, que tendem a ser mais trabalhosos e demandam maiores investimentos, já que algumas das atrações da pecuária extensiva são justamente os baixos investimentos e o pouco trabalho para manutenção do gado (JOLY, 1990).

Nos últimos anos, houve grande crescimento no volume de informações técnico-científicas publicadas sobre os SSPs que envolvem o plantio de árvores. Porém, a maioria das pesquisas trata dos aspectos biofísicos e técnicos desses sistemas, sendo muito raros os estudos que buscam o entendimento dos fatores socioeconômicos, culturais e políticos que facilitariam ou dificultariam a adoção dos SSPs (DIAS-FILHO E FERREIRA, 2007). Questões culturais podem funcionar como entraves, fazendo com que certas dúvidas e mitos sobre os SSPs persistam, sejam eles formados por plantios de árvores ou manutenção da vegetação nativa. Por exemplo, existe uma crença por alguns produtores, que o provimento de sombra aos animais na pastagem, diminui a produção de carne ou leite, pois aumenta o tempo dedicado ao ócio e reduz o tempo de pastejo. Outra crença é que o capim que se desenvolve sob a sombra das árvores seria pouco palatável para o gado, que preferiria o capim que cresceu sob o sol (DIAS-FILHO e FERREIRA, 2007). Esse tipo de conhecimento muitas vezes tem sido disseminado no meio rural, passando a ser aceito como verdade por alguns produtores (DIAS-FILHO e FERREIRA, 2007).

No caso dos SSPs com árvores nativas dispersas, parte do cenário relatado pode ser diferente já que eles são formados, majoritariamente, pelo manejo da regeneração natural ou pelo desmatamento seletivo, ou seja, os investimentos iniciais como a compra, plantio e manutenção das mudas não são necessários. Porém, este tipo de SSP, além de enfrentar algumas dificuldades levantadas acima, ainda não conta, no nosso país, com um arcabouço de pesquisas e publicações como no caso dos SSP implementados com árvores de rápido crescimento. Este tipo de SSP (com árvores nativas dispersas) enfrenta outras dificuldades, diagnosticada em países como Austrália e Costa Rica, como a falta de regeneração dos indivíduos arbóreos e a retiradas para fins madeireiros de árvores que estão nestas pastagens (MANING, 2006). Portanto, o desafio tem sido a manutenção e aprimoramento dos sistemas existentes, além da 
implantação de novas áreas. Outro desafio é estimar as áreas que ocupam, a quantidade e as características das propriedades que os possuem.

\section{CONSIDERAÇÕES FINAIS}

A importância da pecuária no Brasil e no mundo é evidente, assim como a necessidade e desafio de compatibilizar suas questões produtivas e ambientais. Nesse sentido, os SSPs representam uma possibilidade de sucesso e merecem destaque por poderem beneficiar a sociedade tanto localmente (os pecuaristas e suas famílias), como de maneira global, atingindo as regiões e as paisagens. SSPs são indicados para diversas regiões e realidades com as devidas adequações, porém, suas potencialidades se tornam ainda mais evidentes em áreas de chuvas irregulares e baixa fertilidade do solo (MOUSTAKAS, 2013; BLASER, 2013; DOHN et al. 2013; SANCHEZ, 1995; ), como no caso do Cerrado.

Conforme detalhado neste capítulo, são muitas as vantagens dos SSPs, no entanto a concretização de cada uma delas depende da interação das múltiplas variáveis, como por exemplo, as condições físico-biológicas do ecossistema de origem, as espécies envolvidas (animais, capim, árvores), o contexto socioeconômico, político e a cultura local. Portanto, esses sistemas necessitam também de análises complexas que sejam capazes de perceber as diversas interações e medir os benefícios e prejuízos globais. Ciente destes potenciais e desafios torna-se necessário conhecer mais profundamente as experiências já implementadas no Cerrado, especialmente as que são produtivas e englobam alta biodiversidade. Por meio dessa análise, será possível contribuir para a superação dos desafios envolvidos com o propósito de concretizar as potencialidades desses sistemas, bem como para o seu fortalecimento, aperfeiçoamento e ampliação. 


\section{REFERÊNCIAS BIBLIOGRÁFICAS}

ANDERSON, L. S.; SINCLAIR, F. L. Ecological interactions in agroforestry systems. Agrofor. Abs. v. 6, p. 57-91, 1993

ANDRADE, C. M. S.; VALENTIM, J. F.; CARNEIRO, J. DA C. Árvores de baginha (Stryphnodendron guianense) em ecossistemas de pastagens cultivadas na Amazônia Ocidental. Revista Brasileira de Zootecnia, Viçosa, v. 31, n. 2, p. 574-582, 2002.

ANDRADE, C. M. S. et al. Guia arbopasto: manual de identificação e seleção de espécies arbóreas para sistemas silvipastoris, Brasília, DF : Embrapa, 2012, 345p.

ANDRADE, D. C. Economia e meio ambiente: aspectos teóricos e metodológicos nas visões neoclássicas e da economia ecológica. Leituras de Economia Política, v. 14, p. 131,2008

AUAD, A.M. et al; Levantamento da Entofauna de Brachiaria Decumbens em Sistema Silvipastoril. ANAIS DO VIII CONGRESSO DE ECOLOGIA DO BRASIL, 23 a 28 de Setembro de 2007, Caxambu - MG, 2007.

BAKKE, O. A. et al. Produção e utilização da forragem de espécies lenhosas da caatinga. In: GARIGLIO, M. A. et al. Uso sustentável e conservação dos recursos florestais da caatinga. Brasília: Serviço Florestal Brasileiro, 2010. p.160-179.

BALISCEI, M. A. et al. Microclimate without shade and silvopastoral system during summer and winter. Acta scientiarum, v. 35, p. 49-56, 2013.

BELSKY, J. et al. The effects of trees on their physical, chemical and biological evironments in a semi arid savanna in Kenya. Journal of Applied Ecology, v. 26, p. 1005-1024, 1989.

BELSKY, A. J. Effects of trees on nutricional quality of understorey gramineous forage in tropical savannas. Tropical grasslands, v. 26, p. 12-20, 1992.

BELSKY, A. J. Influences of trees on savanna productivity: test of shade, nutrients and tree-grass competition, 1994.

BERGMEIER, E., PETERMANN, J., SCHRODER, E. A geobotanical survey of woodpasture habitats in Europe: diversity, threats and conservation. Biodivers. Conserv. V. 19, p. 2995-3014. 2010.

BERNARDINO, F. S.; GARCIA, R. Sistemas silvipastoris. Pesquisa Florestal Brasileira. Colombo. v. 60, p. 77-87, 2009.

BETANCOURT, K. et al. Efecto de la cobertura arbórea sobre el comportamiento animal en fincas ganaderas de doble propósito em Matiquas. Agroflorestería en las Américas, Matagalpa: Nicaragua, v. 10, p. 47-51, 2003. 
BHAGWAT, S. A. et al. Agroforestry: A refuge for tropical biodiversity? Trends in Ecology and Evolution, v.23, n. 5, p.261-267, 2008.

BLACKSHAW, J. K.; BLACKSHAW, A. W. Heat stress in cattle and the effect of shade on production and behaviour: a review. Australian Journal of Experiment Agriculture, Collingwood, v.34, n.2, p.285-95, 1994.

BIELING, C., KONOLD, W., Common management of wood-pastures and sustainable regional development in the southern Black Forest (Germany). In: HARTEL, T., PLIENINGER, T. (Eds.), European Wood-pastures in Transition: A Social- Ecological Approach. Earthscan from Routledge, Abingdon, New York, 2014, p. 235- 253.

BLASER, W. J. et al. Facilitative or competitive effects of woody plants on understorey vegetation depend on $\mathrm{N}$-fixation, canopy shape and rainfall. Journal of Ecology, v. 101, p. $1598-1603,2013$

BRASIL, MINISTÉRIO DO MEIO AMBIENTE. Mapeamento do uso e cobertura da terra do Cerrado: Projeto TERRACLASS Cerrado 2013. Brasília, 2015a, 69 p.

BRÁZ, S. P.; NASCIMENTO JR., D. N.; CANTARUTTI, R. B. Caracterização da distribuição espacial das fezes por bovinos em uma pastagem de Brachiaria decumbens. Revista Brasileira de Zootecnia. Viçosa, v. 32, n. 4, p.787-794, 2003.

BRESHEARS, D. D. Effects of woody plants on microclimate in a semiarid woodland: soil temperature and evaporation in canopy and intercanopy patches. International Journal of Plant Sciences, v. 159, p. 1010-1017. 1998

BUNGENSTAB, D. J. Sistemas de integração a poduçao sustentável: lavoura,pecuária e floresta. 2ed, Brasília: Embrapa, 2012, 240p.

CALDWELL, M. M.; RICHARDS, J. H., Hydraulic lift: water efflux from upper roots improves effectiveness of water uptake by deep roots. Oecologia. v.79, p. 1-5. 1989

CALLAWAY, R. M. Positive interactions among plants. Botanical Review, v. 61, p. 306-349. 1995

CALlE, A.; MONTAGNINI, F.; ZULUAGA, A. F. Farmer's perceptions of silvopastoral system promotion in Quindío, Colombia. Bois et Flret des Tropiques, v. 300, n. 2, p.80-94, 2009

CAPORAL, R. C.; COSTABEBER, J. A. Agroecologia e Extensão Rural, contribuições para a promoção do desenvolvimento rural sustentável. Brasília: MDA/SAF/DATERIICA, 2004. v. 1, 166 p. 
CARVAlHO, M. M.; FREITAS, V. P.; ANDRADE, A. C. Crescimento Inicial de cinco gramíneas tropicais em um sub-bosque de angico vermelho (Anadenanthera macrocarpa Benth). Pasturas Tropicales, v.17, n. 1, p. 24-30, 1995

CARVALHO, M. M. Arborização de pastagens cultivadas. Juiz de Fora: EMBRAPACNPGL, 1998.

CASTILLO, J. M. D. Provisión de los servicios ecosistémicos carbono y madera en pasturas activas del Corredor Biológico Volcánica Central Talamanca, Costa Rica. 2013. 61 f.. Dissestação (Magister Scientiae en Agroforestería Tropical) Centro Agronómico Tropical e Investigación y Enseñanza Escuela de Posgrado. Turrialba, Costa Rica, 2013

CARVALHO, R., GOEDERT, W., ARMANDO, M. Atributos físicos da qualidade de um solo sob sistema agroflorestal. Pesq. agropec. bras., Brasília, v.39, n.11, p.11531155, nov. 2004

CASASOLA, F. et al. Implementación de sistemas silvopastoriles y el pago de servicios ambientales en Esparza, Costa Rica: una herramienta para la adaptación al cambio climático en fincas ganaderas. In: SEPÚLVEDA, C. J.; IBRAHIM, M.(eds.) Políticas y sistemas de incentivos para el fomento y adopción de buenas prácticas agrícolas: como una medida de adaptación al cambio climático en América Central. Turrialba, Costa Rica: CATIE, 2009. p. 179-188.

CAVALCANTI, C. Concepções da economia ecológica: suas relações com a economia dominante e a economia ambiental. Estudos Avançados, v. 24, n. 68, p. 53-67, 2010.

CONCEIÇÃO, G. M. da. Caracterização botânica e fitossociologia de uma área de cerrado, no Maranhão, sob pastejo por Bovinos. Jaboticabal, 2012. Tese: Faculdade de Ciências Agrárias e Veterinárias - UNESP, 2012

COSTA, M. R. G. F. et al. Utilização do feno de forrageiras lenhosas nativas do Nordeste brasileiro na alimentação de ovinos e caprinos. Publicações em Medicina Veterinária e Zootecnia - PUBVET, Londrina, v. 5, n. 7, p. 1035, 2011.

COSTA, F. P.; et al. Custo-benefício dos sistemas de produção em integração. In: Sistemas de integração lavoura-pecuária-floresta: a produção sustentável. $2^{\circ}$ ed. EMBRAPA, Brasília, DF. 2012.

CUBBAGE, F. et al. Comparing silvopastoral systems and prospects in eight regions of the world.. Agroforest syst, v. 86, p. 303-314, 2012 
DAGANG, A. B. K.; NAIR, P. K. R. Silvopastoral research and adoption in Central America: recent findings and recommendations for future directions. Agroforestry Systems, v.59, p.149-155, 2003.

DANIEL, O.; PASSOS, C. A. M.; COUTO, L. Sistemas agroflorestais (silvipastoris e agrossilvipastoris) na Região Centro-Oeste do Brasil: potencialidades, estado atual da pesquisa e da adoção de tecnologia. In: Sistemas Agroflorestais: A agropecuária sustentável. EMBRAPA, Brasília, DF. 2001.

DA SILVA, R. G. Predição da configuração de sombras de árvores em pastagens para Bovinos, Eng. Agríc., Jaboticabal, v.26, n.1, p.268-281, jan./abr. 2006.

DE MOURA, et al. Estratégias para minimização do estresse calórico em bovinos leiteiros. Rio de Janeiro, RJ. A Lavoura, v.106, pp. 22-26, 2003.

DIAS, P. F. et al. Árvores fixadoras de nitrogênio e macrofauna do solo em pastagem de híbrido de Digitaria. Pesquisa agropecuária brasileira, Brasília, v.41, n.6, p.1015-1021, jun. 2006.

DIAS FILHO, M. B. Sistemas silvipastoris na recuperação de áreas degradadas. Belém: EMBRAPA Amazonia Oriental, 2006. 30p. (Documentos, 258).

DIAS FILHO, M. B.; FERREIRA, J.N. Barreiras à adoção de sistemas silvipastoris no Brasil. In: Fernandes, E. N.; Pacuillo, D. S.; Castro, C. R. T. de; Muller, M. D.; Arcuri, P. B.; Carneiro, J. da C.. (Org.). Sistemas agrossilvipastoris na América do Sul: desafios e potencialidades. Juiz de Fora: Embrapa Gado de Leite, 2007, p. 327-340.

DIAS FILHO, M. B. Degradação de pastagens: processos, causas e estratégias de recuperação. Revista atual e ampliada, Belém, n. 4, p. 216, 2011.

DIAS FILHO, M. B. Diagnóstico das pastagens no Brasil. EMBRAPA Amazônia Oriental, Belém, v. 402, 2014. 36p.

DOHN, J. Tree effects on grass growth in savannas: competition, facilitation and the stress-gradient hypothesis. Journal of Ecology, v. 101, p. 202-209, 2013.

DURR, P. A.; RANGEL, J. The response of Panicum maximum to a simulated subcanopy environment. Tropical grassland, v. 34, p. 110-117, 2000.

FAOSTAT. 2013. Disponível em: http://faostat.fao.org. Acessado em: 18 de novembro de 2015.

FERNANDEZ, M. E. et al. Silvopastoral systems in northwestrn Patagonia: growth and photosynthesis of Stipa speciosa under different levels of Pinus ponderosa cover. Agroforestry systems, v. 55, p. 27-35, 2002. 
FERNANDES, M. R. A tree with much authority: the place of the buriti palm (Mauritia flexuosa L.f.) in the Sertaneja culture of Terra Ronca, Goiás State, Central Brazil. Bioremediation, Biodiversity, and Bioavailabilit, v.5, n.1, p. 80-91, 2011.

FERREIRA, L. C. B. Respostas fisiológicas e comportamentais de bovinos submetidos a diferentes ofertas de sombra, 2010. 89 f. Dissertação (mestrado). Universidade Federal de Santa Catarina, Florianópolis , 2010

FOLEY, J. et al. Global consequences of land use. Science, v. 309, p. 570-574, 2005.

FOLEY J. A. et al, Solutions for a cultivated planet. Nature, v.478 p.337-342. 2011

FRANK, I. L.; FURTADO, S. C. Sistemas silvipastoris: fundamentos e aplicabilidade. Rio Branco: Embrapa Acre, 2001. 51p. (Documentos, 74).

GARCIA, R.; COUTO, L. Sistemas silvipastoris: tecnologia emergente de sustentabilidade. Simpósio internacional sobre produção animal em pastejo, Viçosa: UFV, 1997. p.447-471.

GAUGHAN, J. B. et al. Assessing the heat tolerance of 17 beef cattle genotypes. International Journal of Biometeorology, v.54, n.6, p.617-627, 2009

GERBER, P. et al. Tackling climate change through livestock: a global assessment of emissions and mitigation opportunities. Food and Agriculture organization of the united nations (FAO), Rome, Italy, 2013. 115 p.

GLASER, F.D. Aspectos comportamentais de bovinos das raças Angus, Caracu e Nelore a pasto frente à disponibilidade de recursos de sombra e água para imersão. 2008. 117 f. Tese (Doutorado em Zootecnia) - Universidade de São Paulo (USP), Pirassununga, 2008

GREGORY, N. G. The role of shelterbelts in protecting livestock: a review. New Zeland Journal of Agrocultural Research, Wellington, v. 38, p. 423-450, 1995

GROVE, A. T.; RACKHAM, O. The nature of Mediterranean Europe: an ecological history. New Haven, USA: Yale University Press, 2001. 384 p.

GUISELINI, C.; SILVA, I. J. O.; PIEDADE, S. M. Avaliacao da qualidade do sombreamento arbóreo no meio rural. Rev. Brasileira de Engenharia Agrícola e Ambiental, v.3, n.3, p.380-384, 1999.

HAYNES, R. J.; WILLIAMS, P. H. Nutrient cycling and fertility in the grazed pasture ecosystem. Advances in Agronomy, v.49, p.119-199, 1993.

HARVEY, C. A.; HABER, W. A. Remnant trees and the conservation of biodiversity in Costa Rican pastures. Agroforestry Systems, v. 44, p. 37-68, 1999. 
HARVEY, C. A.; IBRAHIM, M. Diseño y manejo de la cobertura arbórea en fincas ganaderas para mejorar las funciones productivas y brindar servicios ecológicos. Agrofloresteria en las Americas, v. 10, n. 39-40, p. 4-6, 2003.

HARVEY, C. A. et al. Assessing linkages between agriculture and biodiversity in Central America: Historical overview and future perspectives. Mesoamerican and Caribbean Region, San José, CR: The Nature Conservancy (TNC), 2005. 140 p.

HARVEY, C. A. et al. Patterns of animal diversity in different forms of tree cover in agricultural landscapes. Ecological Applications, v. 16, n. 5, p.1986-1999, 2006.

HARVEY, C. A., Conservation value of dispersed tree cover threatened by pasture management. Forest Ecology and Management, v. 261, p. 1664 -1674, 2011

HAWLEY, J. G.; DYMOND, J. R. How much do trees reduce landsliding? Journal of Soil and Water Conservation, v. 43, n. 3, p. 495-498, 1988.

HERNANDÉZ, M. El uso de los árboles como mejoradores de los suelos y de la productividad de las gramineas forrajeras. Pastos y Forrajes, Matanzas, v. 21, n. 4, p. 283-292, 1998.

HERRERO, M. et al. Live-stock, livelihoods and the evironment: Understanding the trade-offs. Current opinion in Environmental sustain-ability, v. 1, p. 111-120, 2009.

HOLMGREN, M.; SCHEFFER, M.; HUSTON, M. A. The interplay of facilitation and competition in plant communities. Ecology, v. 78, p. 1966-1975, 1997.

HOUGHTON, D. Trees and erosion control. Queensland Agricultural Journal, v. 110, n. 1, p. 9-12, 1984.

IBRAHIM, M. et al. Multistrata silvopastoral systems for increasing productivity and conservation of natural resources in Central America. In International Grassland Congress Proceedings. Brasil. v.19, p.645-649, 2001.

JOFRE, R., et. al. The dehasa: an agrosilvopastoral system of the Mediterranean region with special reference to the Sierra Morena area of Spain. Agroforestry Systems. v.6, p. 71, 1988.

JOFRE, R.; RAMBAL, S., Soil Water improvement by trees in the rangelands of Southern Spain. Acta Oecologica Oecol. Plant., v. 9, p. 405-422, 1988.

JOLY, L. G. The conversion of rain forests to pastures in Panama. In: SCHUMANN, D. A. E PARTRIDGE, W. L. (eds.) The Human Ecology of Tropical Land Settlement in Latin America, Colorado, USA: Westview Press, Boulder, 1990. p. 86-132. 
KO, L.; REICH, P. B. Oak tree effects on soil and herbaceous vegetation in savanna and pasture in Wisconsin. Am. Mildl. Nat. v.130, p. 32-42, 1993

KOLLER, W. W. Ocorrência de cigarrinhas das pastagens e de seu predador natural Salpingogaster nigra Schiner sob efeito de sombreamento. Campo Grande: EMBRAPACNPGC, 1988. 15 p. (EMBRAPACNPGC. Documentos, 37.).

KRUSCHEWSKY, G.C. Distribuição Espacial de Fezes de Bovinos em Sistema Silvipastoril e em Convencional: Estudo de Caso no Noroeste do Paraná. Dissertação (Mestrado em Agroecossistemas), Universidade Federal de Santa Catarina, Florianópolis, 2009.

LAPOLA, D. M. et al. Pervasive transition of the Brazilian land-use system. Nature climate change., v. 4, p. 27-35, 2014.

LARIOS, J.; HERNÁNDEZ, J. Fisiografía, ambientes y uso agrícola de la tierra em Tabasco, México. Universidad Autónoma Chapingo. Chapingo, México, 1992.

LAZO, J. A.; VALDÉS, N. V.; SAMPAIO, R. A. Diversidad zoológica asociada a un silvopastoreo leucaena-guinea con diferentes edades de establecimiento. Pesquisa Agropecuária Brasileira, Brasília, v.42, n.12, p.1667-1674, dez. 2007.

LEE, D.R. Agricultural sustainability and technology adoption issues and policies for developing countries. American Journal of Agriculture Economics, v.87, p.1325-1334, 2005.

LIMA, I. L. P.. Manejo de produtos florestais por agricultores tradicionais visando o enriquecimento de uma paisagem de Cerrado no norte de Minas Gerais. 141f. Tese (doutorado em Ecologia) - Instituto de Ciências Biológicas, Universidade de Brasília, Brasília, 2016.

LÓPEZ, D. T.; IBRAHIM, M.; CASASOLA, F. Diversidad de mariposas en un paisaje agropecuario de Pacífico Central de Costa Rica. Agroforestería en las Américas, n. 45, p. 58-65, 2007.

LÚCIO, S. L. B.. Gestão participativa e conflitos socioambientais em áreas protegidas no Cerrado mineiro: a pecuária de solta na RDS Veredas do Acari/MG. Dissertação de mestrado: Centro de Desenvolvimento Sustentável. Universidade de Brasília, BrasíliaDF, 2013, p. 123.

LUDWIG, F., et al. Below-ground competition between trees and grasses may overwhelm the facilitative effects of hydraulic lift. Ecology Letters, v. 7, p. 623-631, 2004. 
LUNT, I. D. Effects of stock grazing on biodiversity values in temperate native grasslands and grassy woodlands in SE Australia: A literature review. Canberra, Australia: Environment ACT,. 2005, p.60.

MCADAM, J. H. et al. Developing silvopastoral systems and their effects on diversity of fauna. Agroforestry Systems, v. 70, p. 81-89, 2007.

MAIA, G. N. Caatinga: árvores e arbustos e suas utilidades. 1. ed. São Paulo: D\&Z Computação Gráfica e Editora, 2004.

MALAFAIA, P.; BARBOSA, J. D.; TOKARNIA, C. H.; OLIVEIRA, C. M. C. Distúrbios comportamentais em ruminantes não associados a doenças: origem, significado e importância, Pesquisa Veterinária Brasileira, Rio de Janeiro, v. 31, p. 781790,2011

MANNING, A. D.; FISCHER, J.; LINDENMAYER, D. B. Scattered trees are keystone structures - Implications for conservation. Biological Conservation, v. 132, p. 311-321, 2006.

MANTYKA-PRINGLE, C.S., MARTIN, T.G., RHODES, J.R., Interactions between climate and habitat loss effects on biodiversity: a systematic review and meta-analysis. Glob. Change Biol. v. 18, 2011. p. 1239-1252.

MATTISON, E. H. A.; NORRIS, K. Bridging the gaps between agricultural policy, land-use and biodiversity. Trends in Ecology \& Evolution, v. 20, p. 610-616, 2005.

MENEZES, R. S. C.; SALCEDO I. H.; ELLIOTT, E. T. Microclimate and nutrient dynamics in a silvopastoral system of semiarid northeastern Brazil. Agroforestry Systems, v. 56, p. 27-38, 2002.

MILIANI, T. et al. Oferta de forraje en un sistema silvopastoril en la región noreste del estado Guarico, Venezuela. Zootecnia Tropical, v. 26, p. 297-299, 2008.

MIMENZA, H. E. Tree resources in tradicional silvopastoral, systems and their impact on productivity and nutritive value of pastures in the dry tropics of Costa Rica. Tropical agriculture research and higher education center, Turrialba, p. 160, 2007.

MIMENZA, H. E. Dispersed trees in pasturelands of cattle farms in a tropical dry ecosystem. Tropical and subtropical agroecosystems, v. 14 p. 933-941, 2011.

MORIN, E. Introduçao ao pensamento complexo. Lisboa: Instituto Piaget. 1990

MORIN, E. Os sete saberres necessários à educaçao do futuro. São Paulo: Cortez, Brasília; UNESCO, 2000 
MUCHAGATA, M.; BROWN, K. Cows, colonist and trees: rethinking cattle and environmental degradation in Brazil Amazonia. Agricultural systems, v. 76, p. 797-816, 2003

MMA/IBAMA. Monitoramento do bioma Cerrado 2009-2010. Relatório Técnico Monitoramento do desmatamento dos biomas brasileiros por satélite, Brasília. 2011.

MOUSTAKAS, A.; et al. Facilitation or competition? Tree effects on grass biomass across a precipitation gradient. Plos One, v. 8, n. 2, e57025, 2013

MURGUEITIO, R. E.; IBRAHIM, M. Ganadería y medio ambiente en América Latina. In: Murgueitio, E., Cuartas, C., Naranjo, J.F (eds.). Ganadería del futuro: Investigación para el desarrollo. CIPAV, Cali, Colombia. 2008, p. 19-40..

MURGUEITIO, R. E.; et al. Native trees and shrubs for the productive rehabilitation of cattle ranching lands. Forest ecology and management., v. 261, p. 1654-1663, 2011.

NARANJO, L. Sistemas agroforestales para la producción pecuaria y la conservación de la biodiversidad. SÁNCHEZ, M. D., SALES, M.. Agroforestería para la producción animal en América Latina-II. Estudio FAO. Producción Animal, p. 1327,2003

NICODEMO, M. L. F. et al. Sistemas silvipastoris - introdução de árvores na pecuária do Centro-Oeste brasileiro. Campo Grande: Embrapa Gado de Corte, 2004. p. 17-20. (Embrapa Gado de Corte. Documentos, 146).

NÓBREGA, G. H. et al. Produção animal sob a influência do ambiente nas condições do semiárido nordestino. Revista verde de agroecologia e desenvolvimento sustentável, v. 06, n. 01, p. 67- 73, 2011.

OLIVARES, A., CARO, W. Efecto de la presencia de sombra en el consumo de agua y ganancia de peso de ovinos en pastoreo. Agro Sur, v. 26, n. 1, p.77-80. 1998

OLIVEIRA, M. E. Influência de árvores das especies nativas dipteryx alata Vog. e caryocar brasiliense Camb. no sistema solo-planta em pastagem de brachiaria decumbens Stapf no cerrado. 1999. 104 p. Tese (Doutorado em Ecologia) Faculdade de Ciências Biológicas, Universidade de Brasília, Brasília, 1999.

OLIVEIRA, M. E. et al. Efeito de duas espécies nativas de árvores sobre as propriedades do solo e forragem de Brachiaria decumbens. Pasturas Tropicales, v. 27, n. $1,2005$.

OTERO-ARNAIZ, A. et al. Isolated pasture trees and the vegetation growing under their canopies in the Chiapas Coastal plain México. Biotropico, v. 31, p. 243-254, 1999. 
PACIULLO, D. S. C. et al. Morfofisiologia e valor nutritivo do capim-braquiária sob sombreamento natural e a sol pleno. Pesquisa Agropecuária Brasileira, Brasília, v.42, n.4, p.573-579, 2007.

PAGIOLA, S. et al. Paying for the environmental services of silvopastoral practices in Nicaragua. Ecol. e econ. v. 64, p.374-385, 2007.

PAGIOLA, S. Payments for environmental services in Costa Rica. Ecological Economics, v. 65, p.712-724, 2008

PASSINI, R. et al. Estresse térmico sobre a seleção da dieta por bovinos. Rev. Acta Scientiarum. Animal Sciences, v. 31, n. 3, p. 303-309, 2009.

PATTANAYAK, S. K. et al. Taking stock of agroforestry adoption studies. Agroforestry Systems. v. 57, p. 173-186, 2003.

PEREIRA, E. S. Digestão intestinal da proteína de forrageiras e coprodutos da agroindústria produzidos no Nordeste brasileiro por intermédio da técnica de três estágios Rev. Bras. Saúde Prod. Animal, v.11, n.2, p. 403-413 abr/jun, 2010.

PETERS, M. et al. Challenges and opportunities for improving eco-efficiency of tropical forage-based systems to mitigate greenhouse gas emissions. Tropical Grasslands-Forrajes Tropicales v.1 p.137-148. 2013.

PEZZOPANE, J. R. M. et al. Microclimate and soil moisture in a silvopastoral system im southeastern Brazil., Bragantia, Campinas, v. 74, p. 110-119, 2015.

PLIENINGER, T. et al., Wood-pastures of Europe: Geographic coverage, socialecological values, conservation management, and policy implications. Biological Conservation, v. 190, p. 70-79, 2015.

POLLOCK, K. M.; MEAD, D. J.; MCKENZIE, B. A. Soil moisture and water use by pastures and silvopastures in a sub-humild temperate climate in New Zealand. Agroforestry systems, v. 75, p. 223-238, 2009.

PORFÍRIO-DA-SILVA, V. Modificações microclimáticas em sistema silvipastoril com Grevillea robusta A. Cunn. Es. R. Br. no noroeste do estado do Paraná. Dissertação de Mestrado: Florianópolis: UFSC, 1998. 128p.

POTT, E. B.; POTT, A. Níveis de nutrientes em plantas não-gramíneas pastejadas por bovinos na sub-região dos paiaguãs, do Pantanal Mato-grossense. Pesquisa Agropecuária Brasileira, Brasília, v. 22, n.1112, p. 1293-1299, nov./dez. 1987.

PULIDO F. et al., Libro Verde de la Dehesa: Documento para el debate hacia un Estrategia Ibérica de gestión. Salamanca: Junta de Castilla y León, Sociedades 
Españolas de Ciencias Forestales, para el Estudio de los Pastos y de Ornitología, Asociación Española de Ecología Terrestre. 2010. 48p.

RESTREPO, C. Relaciones entre la cobertura arbórea en potreros y la producción bovina em fincas ganaderas em el trópico seco, Cañas, Costa Rica. 2002, 102p. Dissertação: CATIE, Turrialba, Costa Rica, 2002

RIOS, N.; ANDRADE, H.; IBRAHIM, M. Evaluación de la recarga hídrica en sistemas silvopastoriles en paisajes ganaderos. Zootecnia Trop., v. 26, n. 3, p. 183-186, 2008 ROZADOS-LORENZO, M. J.; GONZÁLEZ-HERNÁNDEZ, M. P.; SILVIO-PANDO, F. J. Pasture production under different tree species and densities in an Atlantic silvopastoral.. Agroforestry systems, 2007.

SANCHEZ, P. A. Science in agroforestry. Agrofor Syst., v. 30, p. 5-55. 1995.

SÁNCHEZ, M.D. Panorama dos sistemas agroflorestais pecuários na América Latina. In: CARVAlHO, M.M.; ALVIM, M.J.; CARNEIRO, J.C. (Eds.). Sistemas agroflorestais pecuários: opções de sustentabilidade para áreas tropicais e subtropicais. Juiz de Fora: Embrapa Gado de Leite; Brasília: FAO, 2001. p.9-17.

SANCHEZ, M. Sistemas agroflorestales para intensificar de manera sostenible la produccíon animal em América latina tropical. In: SÁNCHEZ, M. D.; ROSALES, M. M. Agroflorestería para la producción animal em América Latina., p. 1-13, 1999.

SANTOS, M. V. F. et al., Composição Florística, Densidade e Altura de uma Pastagem Natural sob Pastejo. Rev. Bras. Zootecnia, v. 27, n. 6, p. 1082-1091, 1998

SANTOS, S. A.; et al. Composição Botânica da Dieta de Bovinos em Pastagem Nativa na Sub-Região da Nhecolândia, Pantanal. Rev. Bras. Zootecnia, v.31, n.4, p.16481662,2002

SANTOS, S. A.; et al. Grau de Preferência e Índice de Valor Forrageiro das Pastagens Nativas Consumidas por Bovinos no Pantanal. Corumbá -MS, EMBRAPA: Boletim de Pesquisa e Desenvolvimento 49. 2003

SILVA-PANDO, F. J.; GONZÁLEZ-HERNÁNDEZ, M. P.; ROZADOS-LORENZO, M. J. Pasture production in a silvopastoral system in relation with microclimate variables in the Atlantic coast of Spain. Agroforestry systems, v. 56, p. 203-211, 2002. SMITH, J.; SHERR, S. J. Forest carbon and local livelihoods: assesment of opportunities and policy recommendations. Jackarta: Center for International Forestry Research, 2002. CI-FOR Ocasional Paper, 37. 
SOUSA, L. F. et al., Nutritional evaluation of "Braquiarão" grass in association with "Aroeira" trees in a silvopastoral system. Agroforestry Systems. v. p. 79, 179-189. 2010

STEINFELD, H. et al. Livestock's long shadow: environmental issues and options. FAO, Roma: Itália, 2006

THUROW, T. L. et al. Rainfall interception by midgrass, shortgrass and live oak mottes. Journal Range Management. v. 40, p.455-460, 1987

UNITED NATIONS ENVIRONMENT PROGRAMME. Land degradation in drylands (LADA): GEF grant request. Nairobi, Kenya, 2004.

VALVERDE, O. Geografia da pecuária no Brasil, 1967. Disponível em http://www.ceg.ul.pt/finisterra/numeros/1967-04/04_04.pdf Acesso em 26 de maio de 2016.

VETAS, R. O. Micro-site effects of trees and shrubs in dry savannas. Journal of Vegetarian Science, v. 3, p. 337-344, 1992.

VILLANUEVA, C.; et al. Decisiones claves que influyen sobre la cobertura arbórea en fincas ganaderas de cañas, Costa Rica. Agrofloresteria en las Americas., v. 10, n. 3940, p. 68-77, 2003.

VILLANUEVA, C. et al., Disponibilidad de Brachiaria brizantha en potreros con diferentes niveles de cobertura arbórea en el trópico subhumedo de Costa Rica. Zootecnia Trop., v. 26, n 3, p. 293-296, 2008

WIRSENIUS, S. The biomass metabolism of the food system: a model based survey of the global and regional turnover of food biomass. Journal of industrial., v. 7, p. 47-80, 2003.

YAMAMOTO, W., DEWI, I. A., IBAHIM, M., Effects of silvopastoral areas on milk production at dual-purpose cattle farms at the semi-humid old agricultural frontier in central Nicaragua. Agroforestry Systems. v. 94, p. 368-375. 2007.

ZAMORA, S. Cómo utilizar los frutos de guanacaste (Enterolobium cyclocarpum), guácimo (Guazuma ulmifolia), genizaro (Phitecellobium saman) y jícaro (Crescentia alata) en la alimentación animal. Agroforestería en las Américas., v. 8, n.31, p. 45-49, 2001.

ZANINE, A. M. et al. Composição bromatológica de leguminosas do semi-árido do Brasil. Livestock Research for Rural Development, v.17, n.8, 2005. 


\section{CAPITULO 2 - CARACTERIZAÇÃO DE PASTAGENS ARBORIZADAS COM ESPÉCIES NATIVAS NO CERRADO E DIAGNÓSTICO DOS SABERES DOS PECUARISTAS.}

\section{INTRODUÇÃO}

O Cerrado é a savana mais rica do mundo, possui 12097 espécies de angiospermas, das quais 35,1\% são endêmicas (BRAZIL FLORA GROUP, 2015), porém apenas 8,2\% da sua área está localizada em Unidades de Conservação (CNUC/MMA, 2016). Apesar de sua elevada diversidade e relevância, o Cerrado já foi reduzido a quase metade do seu tamanho original. Os últimos dados, relativos a 2013, revelaram que 43,4\% da sua área já havia sido desmatada ${ }^{2}$ (BRASIL/MMA 2015a). É alarmante a velocidade que este processo se deu, pois bastaram pouco mais de cinco décadas para que este alto percentual fosse atingido, fruto, principalmente, de incentivos agrícolas do governo federal, desenvolvimento de tecnologias agrícolas, fatores topográficos e edafoclimáticos favoráveis que fizeram desta região um dos maiores produtores e exportadores de produtos agropecuários do mundo (KLINK e MOREIRA, 2002; BRANNSTROM et al., 2008). Portanto, a alta riqueza e endemismo de espécies e a grande alteração ambiental fizeram do Cerrado um dos 34 hotspots mundiais para a conservação (MYERS et al., 2000).

Porém, para conservação deste bioma, além da criação e bom manejo de áreas protegidas é necessário o uso sustentável do solo e da biodiversidade nas áreas produtivas das propriedades rurais (PERFECTO e VANDERMEER 2010; BHAGWAT et al., 2008; JEPSON, 2005). Para isso, políticas, fomentos e ações relacionados a agricultura sustentável e restauração de áreas degradadas crescem no Brasil (SAWYER, 2009; BARBOSA et al, 2007; BRASIL/MMA, 2015a). Porém, dentre várias ações para conservação e restauração dos ecossistemas e da biodiversidade, praticamente inexistem incentivos à manutenção das árvores nativas existentes nas áreas produtivas fora das Reservas Legais, como nas pastagens (SCHIRMER et al., 2012), assim como faltam estímulos ao enriquecimento destas áreas.

\footnotetext{
2 Este dado alcançou nível de precisão de 80,2\% (BRASIL/MMA, 2015a). O valor relativo ao desmatamento no Cerrado até o 2011 foi 5,5\% superior a este valor relativo a 2013 (BRASIL, MMA,2015b) e este faro deve-se, principalmente, à diferenças metodológicas das duas avaliações (BRASIL/MMA, 2015a).
} 
Pastagens com árvores nativas dispersas caracterizam-se como um tipo de sistema silvipastoril dentre diversos outros modelos de integração entre animais, pastagem e árvores (ANDRADE, et al. 2012; FRANKE e FURTADO, 2001). Este tipo de sistema existe em diversos países com ecossistemas florestais e savânicos e foram formados pelo desmatamento seletivo, condução da regeneração natural e, com menos frequência, por plantios (GROVE e RACKHAM 2001; PLIENINGER et al., 2015; LUNT, 2005; MIMENZA, 2011). A intensidade das pesquisas, grau de compreensão e valorização destes sistemas variam nas diferentes regiões do globo. Por exemplo, na América Central existem instituições como o $\mathrm{CATIE}^{3}, \mathrm{IICA}^{4}, \mathrm{CIPAV}^{5}$ que possuem um conjunto de trabalhos sólidos que abordam estes sistemas, assim como em diversos países da Europa e na Austrália (HARTEL, 2015; REID e LANDSBERG, 2000).

As pastagens arborizadas com diversidade de espécies nativas apresentam vantagens em relação a pecuária convencional e aos modelos mais simplistas de SSPs por permitirem a diversificação de produtos, aumento da produtividade animal, além de proporcionarem serviços ambientais (GUEVARA et al. 1998, HARVEY e HABER, 1999, BHAGWAT et al., 2008) conforme detalhado no capítulo 1 deste trabalho. Além disso, as espécies arbóreas nativas são frequentemente adaptadas a condições desfavoráveis como a sazonalidade climática e solos de baixa fertilidade, o que diminui a demanda de insumos externos e aumenta a sobrevivência das espécies lenhosas, tornando os sistemas mais resilientes e economicamente viáveis, principalmente às comunidades de baixo poder aquisitivo (CASTRO e PACIULLO, 2006; OLIVEIRAFILHO, 1994).

O Brasil possui diversas pesquisas com SSPs, muitas vezes denominadas "Integração lavoura pecuária e floresta". São muitos experimentos e publicações, com forte envolvimento da Empresa Brasileira de Pesquisa Agropecuária - EMBRAPA, em diversas regiões do país (BUNGENSTAB, 2012; ALVES, 2015). Porém, os trabalhos tem como foco principal SSPs implementados com o plantio de árvores de rápido crescimento, predominantemente do gênero Eucalyptus. Recentemente, os sistemas silvipastoris presentes nas cinco diferentes regiões do Brasil foram apresentados e discutido potenciais, limitações e recomendações para futuras pesquisas em artigo

\footnotetext{
${ }^{3}$ Centro Agronômico Tropical de Pesquisa e Ensino com sede na Costa Rica

${ }^{4}$ Instituto Interamericano de Cooperação para a Agricultura - vinculado à Organização dos Estados Americanos (OEA).

${ }^{5}$ Centro de Pesquisa em Sistemas Sustentáveis de Produção Agropecuária com sede na Colômbia e no Panamá
} 
científico (ALMEIDA et al., 2013). Neste trabalho, quando analisada a região Centro Oeste, onde predomina o Bioma Cerrado, o sistema de pastagem com árvores nativas dispersas não é mencionado, nem mesmo como recomendações para pesquisas futuras, possivelmente pelo não reconhecimento do seu potencial e importância.

É importante saber como e por quê os criadores de gado decidem manter, eliminar ou modificar a cobertura arbórea nas suas pastagens, e como essas decisões impactam o desempenho ambiental e produtivo (HARVEY et al. 2011). Os produtores formam e manejam seus SSPs e assim vão acumulando conhecimento sobre as características das árvores e as interações destas com o solo, o pastos e os animais. Conhecer as práticas de proteção das árvores realizadas pelos pecuaristas pode embasar outros projetos que visam integrar metas de conservação com necessidades de produção nas paisagens agrícolas (MUÑOZ et al., 2003; GARENA et al; 2011). Este conhecimento pode variar entre pessoas, comunidades e regiões (MUÑOZ et al., 2003) influenciado pelas condições climáticas, físicas, socioeconômicas e culturais e dos sistemas de produção (VILlANUEVA et al., 2003). Portanto, é necessário que as investigações destes sistemas sejam amplas, capazes de abordar, especificar e compreender estas variações.

Embora existam inúmeros estudos sobre este tipo de sistema em diversos países, ainda assim relativamente pouco se sabe sobre a diversidade e abundância de árvores dispersas em cada região e como as pastagens estão mudando ao longo do tempo (HARVEY, 2011). É importante conhecer o grau de cobertura arbórea, a composição de espécies, seus padrões de distribuição nas pastagens e como estes fatores variam entre pastagens e regiões para deste modo possibilitar formas adequadas de manejo dos sistemas (HARVEY e IBRAHIM, 2003). Igualmente relevante é compreender as motivações dos pecuaristas que contribuem para tais configurações. Estes conhecimentos são fundamentais para alcançar os potenciais benefícios desta categoria de SSP, otimizando questões produtivas com serviços ambientais.

O presente estudo objetiva caracterizar as pastagens com árvores nativas na porção central do bioma Cerrado, abrangendo regiões dos estados de Minas Gerais, Goiás e Distrito Federal. Pretende-se conhecer (i) a estrutura e a riqueza de espécies arbóreas nativas e de seus regenerantes em pastagens localizadas na área core do Cerrado; (ii) as motivações, dificuldades, práticas de manejo, preferencias e percepções dos pecuaristas sobre o papel destas árvores na pastagem e a interação delas com o gado e as gramíneas; (iii) como os pecuaristas influenciam na estrutura e riqueza de espécies 
arbóreas nas pastagens; (iv) de que forma características dos pecuaristas e do manejo adotado podem estar relacionadas a variação de densidade e riqueza de árvores e regenerantes na pastagens (Figura 1).

A hipótese de trabalho é que as pastagens arborizadas com espécies nativas do cerrado possuem elevada riqueza, com predomínio de espécies multifuncionais e que, os pecuaristas, durante a formação e manejo de suas pastagens, baseiam suas decisões em conhecimentos prévios adquiridos por experiência prática e observacional além de influência cultural. Supõe-se que as preferencias e formas de manejo adotadas por estes sujeitos influenciam a estrutura e riqueza das árvores nativas em suas pastagens. Pretende-se averiguar a hipótese de que a densidade e riqueza de árvores nativas e regenerantes nas pastagens variam inversamente (Figura 1) conforme o nível de intensificação técnica dos pecuaristas (uso de adubos e taxa de lotação animal) e sua faixa de renda (tamanho da propriedade, número de animais).

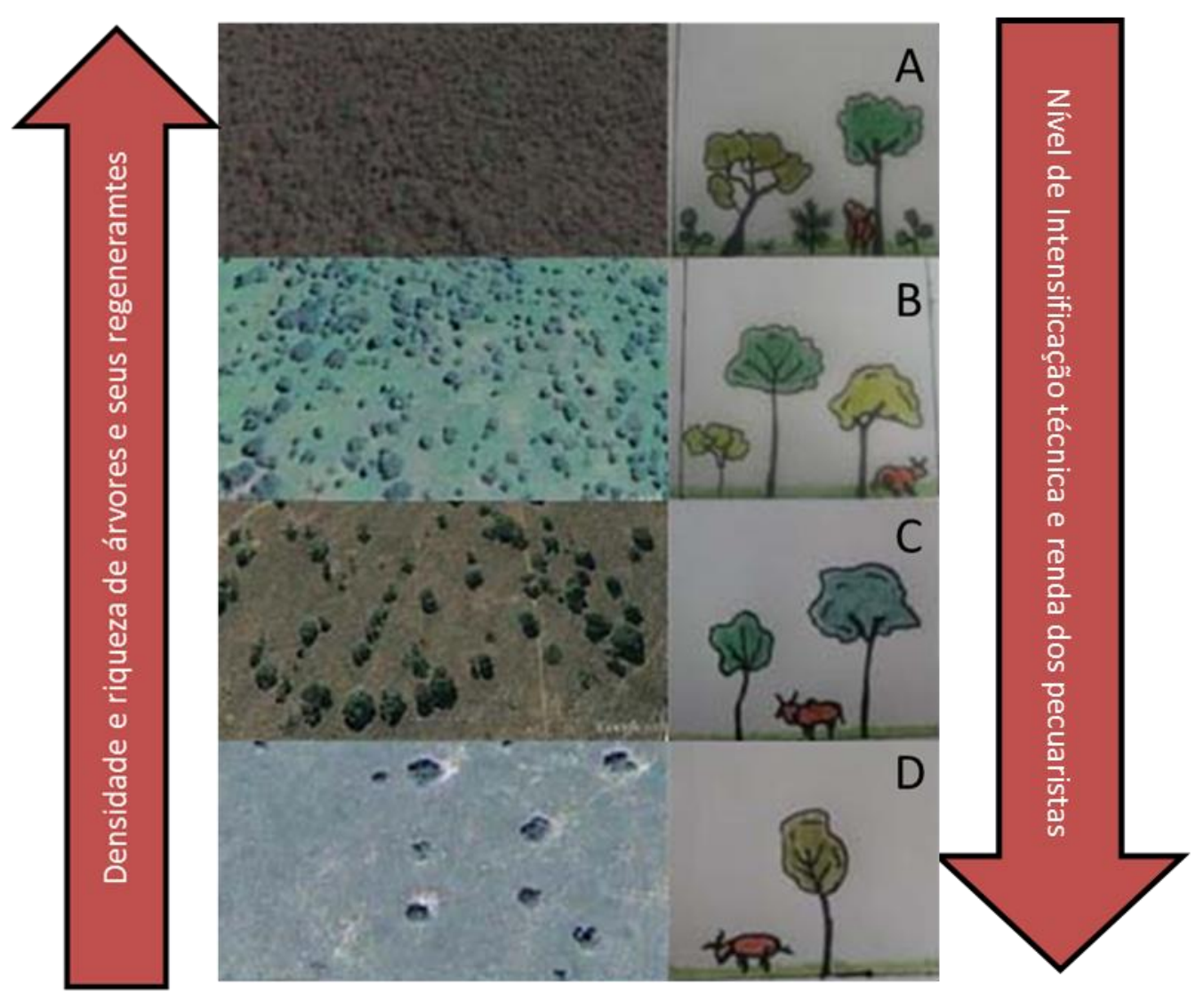

Figura 1: Representação esquemática da hipótese de que a densidade e riqueza de árvores nativas e regenerantes nas pastagens na zona core do Bioma Cerrado variam inversamente conforme o nível de intensificação técnica dos pecuaristas (uso de adubos e taxa de lotação animal) e sua faixa de renda (tamanho da propriedade, número de 
animais). A- Pastagem nativa, sem plantio de gramínea africana e sem desmatamento significativo. B- Pastagem formada pelo desmatamento seletivo de árvores nativas e plantio de gramíneas africanas mantendo grande quantidade de árvores. C- Idem ao B, porém mantendo-se mediana quantidade de árvores. D- Idem ao B, porém com poucas árvores na pastagem.

\section{MATERIAIS E MÉTODOS}

\section{- Seleção das propriedades amostradas}

Adotou-se como pré-requisito para escolha das pastagens, que estas possuíssem no mínimo 5 árvores por hectare, pois o intuito era conhecer pastagens que tivessem de poucas a muitas árvores. O pasto não poderia estar abandonado, sem utilização pelos animais. Com o propósito de restringir o universo amostral, as fitofisionomias originais das áreas pesquisadas deveriam ser de cerrado sentido restrito por ser a principal fisionomia do bioma em área ocupada acrescida do cerradão que floristicamente assemelha-se ao cerrado sentido restrito (RIBEIRO e WALTER, 2008). Algumas vezes, as áreas amostradas possuíam características de transição entre estas fitofisionomias escolhidas com as mata seca ou de galeria. As fitofisionomias originais das áreas amostradas foram identificadas por meio das características da paisagem, tanto no local como em áreas adjacentes e com a identificação de espécies indicadoras. As áreas selecionadas não poderiam compor Áreas de Preservação Permanente ou áreas de Reserva Legal das propriedades, pois nestes ambientes a presença das árvores é exigido por lei.

Os dados foram coletados em 51 pastagens (Figura 2) localizadas em área core do Bioma Cerrado, nos estados de Goiás, Distrito Federal e Minas Gerais. As propriedades estão a uma distancia máxima de $500 \mathrm{Km}$ do Distrito Federal. Estas áreas foram identificadas previamente, com auxílio de Instituições que trabalham na área rural, como Empresa de Assistência Técnica e Extensão Rural (EMATER), Empresa Brasileira de Pesquisa Agropecuária (EMBRAPA), Institutos Estaduais de Meio Ambiente, Organizações Não Governamentais, além de pesquisadores e estudantes de cursos de áreas correlatas. Sete propriedades foram localizadas por contatos já estabelecidos por outros pesquisadores da Embrapa que já desenvolvem pesquisa sobre uso e conservação da biodiversidade nestas locais. Antes de realizar tais viagens definiu-se o caminho que seria percorrido e visualizaram-se as propriedades por meio de 
imagens de satélite no Google Earth tentando identificar outras propriedades com possibilidade de apresentar os pré-requisitos estabelecidos e que estivessem próximas ao caminho. Quando estas propriedades eram localizadas nas imagens, as coordenadas geográficas eram marcadas no GPS para tentar localizá-las no campo e fazer contato com os pecuaristas. Além disso, durante o percurso da viagem, observou-se a paisagem em busca de pastagens com árvores nativas. Muitas vezes, apesar de encontrar pastagens que apresentavam as características para o trabalho, não foi possível entrar nas propriedades por estarem com o acesso bloqueado.

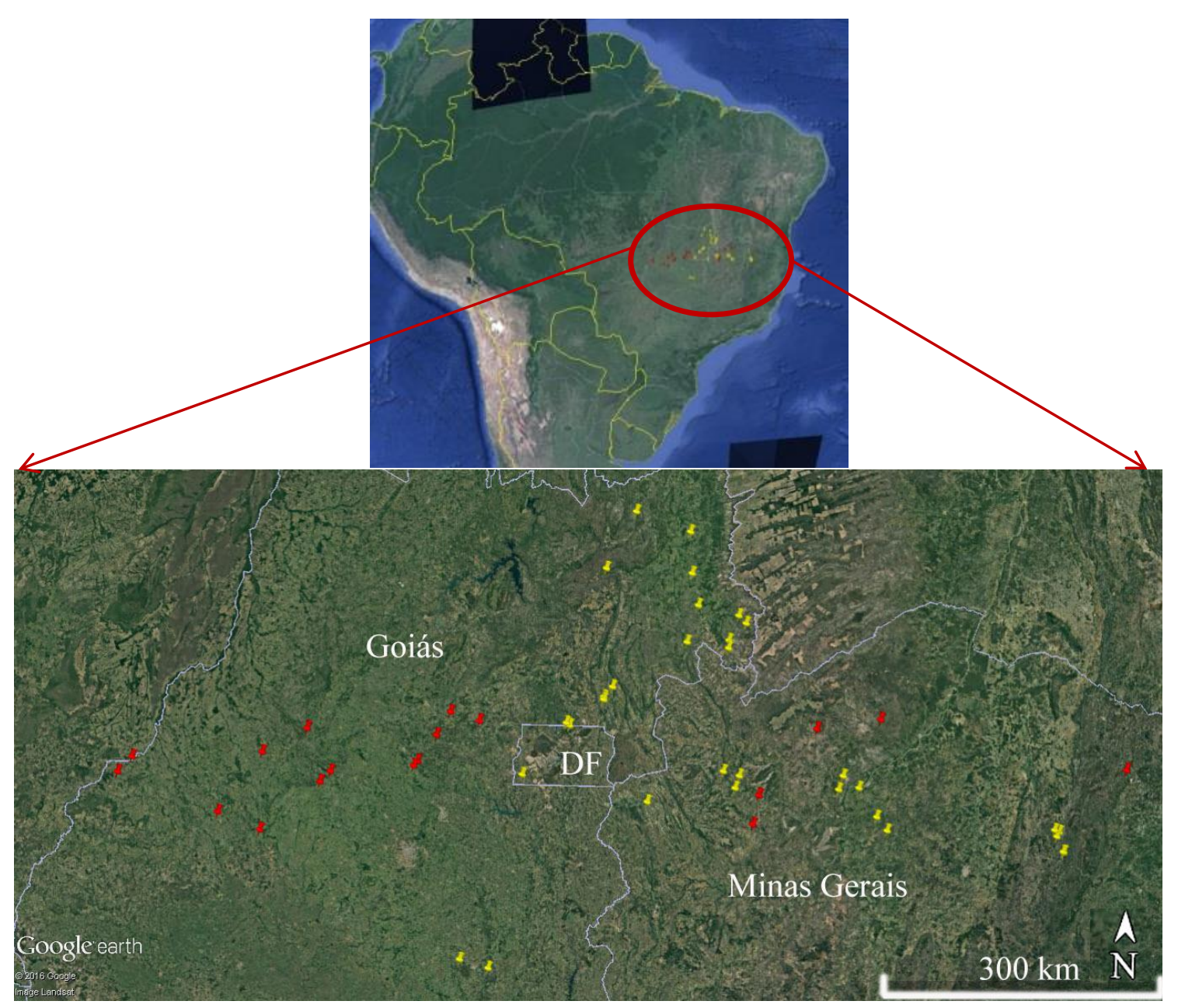

Figura 2: Localização das propriedades estudadas que possuem pastagens com árvores nativas na zona core do Cerrado. Ambos, pontos amarelos e vermelhos, representam locais onde realizou-se entrevistas e estudo das árvores presentes nas pastagem, os pontos amarelos representam locais onde também coletou-se dados da cobertura do solo nas pastagens e os pontos vermelhos onde estudou-se a regeneração natural. 


\section{- Compreensão dos sistemas por meio de entrevistas}

Para compreender estes sistemas de pastagens arborizadas com espécies nativas do cerrado foram realizadas entrevistas semi-estruturadas com os pecuaristas, fossem eles proprietários ou gerentes. A primeira parte das entrevistas continha questões fechadas sobre dados gerais de cada propriedade/agricultor. Em seguida iniciou-se a entrevista semi-estruturada, com questões abertas, que trataram dos temas: a) Motivações e desafios; b) Compreensão da técnica, desde a formação até o manejo; c) Principais produtos úteis. Os tópicos norteadores de cada um destes temas encontram-se no anexo 1. Foram, cautelosamente realizadas adaptações, supressões e acréscimos às questões, de acordo com a sensibilidade da entrevistadora baseados na apresentação do entrevistado e diagnóstico da sua abertura e interesse em conversar sobre os temas.

Primeiramente foi realizado pré-teste com dois pecuaristas para verificar a adequação deste instrumento de coleta de dados. Os principais aspectos observados foram a clareza e precisão dos termos; a quantidade, forma e ordem das perguntas; adequação da introdução que antecede a entrevista; verificação se as respostas dadas não denotaram dificuldades no entendimento das questões e se as respostas às questões abertas foram passíveis de categorização e de análise (GIL, 2002). Em seguida as devidas adequações foram realizadas para as próximas entrevistas.

Antes das entrevistas foi realizado um contato inicial no qual a entrevistadora apresentou-se, explicou os objetivos e importância da pesquisa, pediu licença para gravar, abriu um espaço para esclarecimentos, enfim, criou um ambiente de cordialidade. Em seguida, foi aberto um espaço para apresentação do entrevistado. Orientações importantes foram seguidas como começar com perguntas simples e interessantes, que não assustem, estar atento ao que o entrevistado diz, encorajá-lo por meio do olhar, balanço da cabeça entre outros reforços, respeitar pausas na fala como um momento de reflexão do entrevistado, sondar cuidadosamente mais detalhes do que uma primeira resposta à pergunta (BAUER e GASKEL, 2008).

Não existiu uma sequência precisa das questões, sua ordenação variou de acordo com diálogo estabelecido, procurando sempre que possível deixar as questões conectadas, pois a entrevista é uma ferramenta interativa que adquire sentido dentro de um espaço dialógico, em que o estabelecimento do vínculo entre o pesquisador e os sujeitos investigados cumpre uma função essencial na qualidade das respostas (REY, 1999). 
Portanto, o papel do entrevistador não se restringe à atividade de perguntar. Da mesma forma, o papel do sujeito investigado não se restringe a responder às questões formuladas pelo investigador, pois as suas propostas não estão prontas a priori (dentro de "suas cabeças"), mas são verdadeiras construções pessoais implicadas no espaço dialógico da entrevista.

Adotou-se a entrevista em sua concepção reflexiva na qual foram realizadas sínteses da fala dos entrevistados em alguns momentos com objetivo de mostrar como o entrevistador estava acompanhando a fala do entrevistado, buscando uma imersão no seu discurso. Estas sínteses representam uma oportunidade de trazer a entrevista para o foco que se desejava aprofundar, além de permitir ao entrevistado deparar-se com sua fala e poder realizar correções ou complementações, garantindo maior fidedignidade dos dados coletados (SZYMANSKY et al. 2004). Durante ou logo após as entrevistas a pesquisadora fez anotações sobre suas percepções da conversa, como certo desconforto, confusão, contradição, insegurança ou emoção, diagnosticados pela fala, expressão corporal, atitudes, ou questões vistas no campo.

Estas entrevistas foram gravadas na íntegra com autorização dos pecuaristas e posteriormente foram degravadas. Em seguida foi realizada a organização e sistematização dos dados por meio de repetidas e cuidadosas releituras das entrevistas que foram organizadas de acordo as questões norteadoras. Então, foram criadas categoria e subcategorias de acordo com a semelhança das respostas (categorias " $a$ posteriori") e avaliadas suas frequências. Nesta etapa seguiram-se alguns pressupostos da metodologia de Análise de Conteúdo de Bardin (2011).

\section{Levantamento da riqueza e estrutura das árvores e regenerantes}

Para o levantamento florístico nas pastagens utilizou-se uma parcela amostral de $50 \times$ 200 metros (1 hectare) por propriedade, com intuito que fosse representativa da propriedade (Figura 3). A localização da parcela foi selecionada com base na facilidade de acesso desde que os pré-requisitos fossem atendidos e que ela não destoasse do restante da área. Suas dimensões foram medidas com uma trena de 50 metros, esticada subsequentemente quatro vezes, somando 200 metros. Ao longo da trena, uma pessoa media com um equipamento a laser (Monóculo Bushnell Rangefinder) a distância perpendicular entre a trena e as árvores, incluindo aquelas a uma distancia de até 25 metros. Quando o equipamento registrava valores entre 24 a 26 metros a medida era realizada novamente (pois sua precisão é de 1 metro) com uma outra trena esticada até a 
árvore em questão. Este procedimento foi repetido de ambos os lados da trena, englobando os 50 metros de largura da parcela amostral. As parcelas para amostragem dos indivíduos regenerantes acompanhava a trena central na parcela sendo incluídos na amostragem os indivíduos posicionados até dois metros de largura de cada lado da trena, portanto o tamanho total da parcela foi de 4 metros de largura por 200 de comprimento, totalizando $800 \mathrm{~m}^{2}$. Caso a pastagem tivesse alta densidade de regenerantes, restringiu-se a medição até o quadrante que completasse 100 indivíduos.

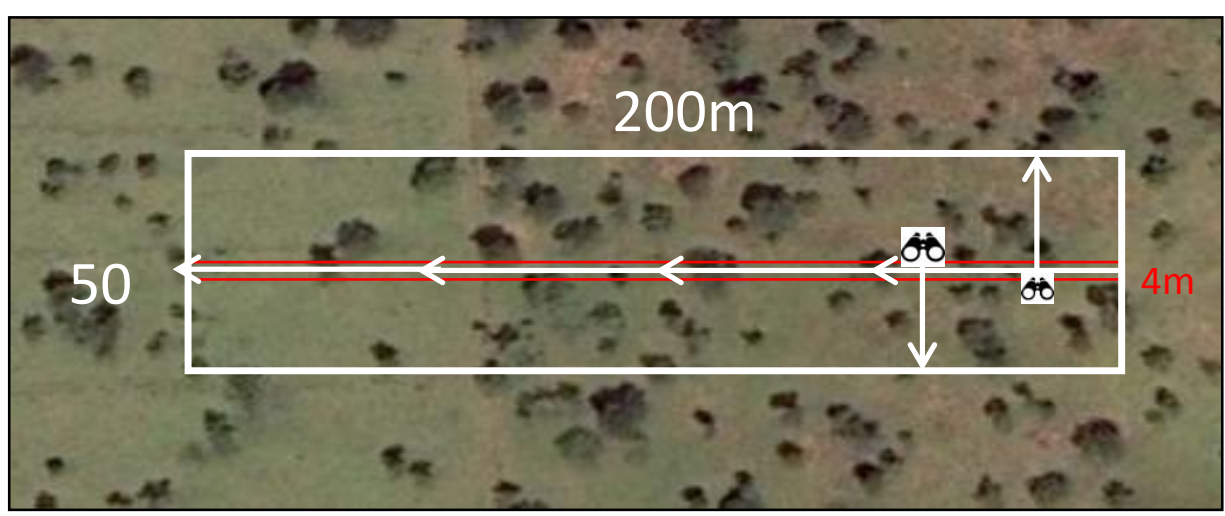

Figura 3: Desenho esquemático que apresenta a metodologia de amostragem na coleta de dados sobre as espécies arbóreas e regenerantes presentes nas pastagens do Bioma Cerrado.

Todas as árvores com diâmetro à altura da base (DAB) maior ou igual a 5 centímetros foram incluídas no levantamento e seu diâmetro medido a $30 \mathrm{~cm}$ do solo com uma suta. Caso a árvore fosse muito grande a ponto de ultrapassar o limite máximo de medição da suta, media-se a circunferência com uma trena e posteriormente a medida foi transformada em diâmetro. Para os indivíduos regenerantes mediu-se altura total com régua milimetrada e o diâmetro à altura do solo (DAS) com auxílio de paquímetro digital. O limite máximo de inclusão como regenerante foi $5 \mathrm{~cm}$ de DAS e o limite mínimo $30 \mathrm{~cm}$ de altura. As árvores e regenerantes foram classificadas ao nível de espécie. Quando houve dúvida na identificação taxonômica, coletas botânicas foram realizadas e preparadas exsicatas para posterior confirmação com auxílio de especialistas do herbário da Embrapa Recursos Genéticos e Biotecnologia. Cada propriedade estudada contribuiu com apenas um caso de estudo, ou seja, realizou-se apenas um levantamento em campo por propriedade.

Para análise da estrutura da vegetação arbórea foram elaboradas as distribuições de frequiências nas classes de diâmetro e os parâmetros fitossociológicos: densidade 
absoluta $^{6}$ e relativa ${ }^{7}$; freqüência absoluta ${ }^{8}$ e relativa ${ }^{9}$, dominância absoluta ${ }^{10}$ e relativa $^{11}$, baseada na área basal $\left(\mathrm{m}^{2} / \mathrm{ha}\right)$. Pelo somatório dos valores relativos dos três parâmetros citados acima encontrou-se o índice de valor de importância (IVI), que é estimador da importância ecológica de cada espécie na comunidade comparativamente as outras existentes (MÜELLER-DOMBOIS e ELLENBERG, 1974).

\section{RESULTADOS}

\section{Dados gerais das propriedade/pecuaristas}

As entrevistas foram realizadas com 51 pecuaristas e totalizaram 26 horas e 38 minutos (média de 34 minutos cada). As propriedades têm em média 339 ha, porém com grande variabilidade (de 4 a 1210 ha), pois buscou-se abranger propriedades com diferentes dimensões e realidades. As áreas de pastagens possuem, segundo informações dadas pelos entrevistados, dimensão média de 194 ha (de 2 a 920 ha). O número médio de animais do rebanho foi de 341 cabeças (de 8 a 2300) sendo $61 \%$ da raça nelore, $10 \%$ girolanda e $29 \%$ cruzamentos. O capim predominante foi braquiária (Brachiaria decumbens Stapf,) presente em $45 \%$ das propriedades, seguido pelo braquiarão (Brachiaria brizantha cv Marandu), com 29\% e andropogon (Andropogon gayanus Kunth,) com 26\%. Os pecuaristas entrevistados possuem a propriedade em média há 19 anos (variando de 1 a 50 anos).

\section{Estrutura e riqueza dos vegetação árborea em SSPs}

Foram avaliadas as pastagens de 47 propriedades, localizadas em 39 munícios nos estados de Goiás, Minas Gerais e Distrito Federal. Foram registrados 3781 indivíduos arbóreos com diâmetro da base superior a $5 \mathrm{~cm}$. O número médio de árvores nas pastagens foi 80,4/ha. Houve grande variação na densidade de árvores nas pastagens avaliadas (6 a 503/ha), sendo que duas propriedades tiveram valores muito elevados e discrepantes dos demais, (outlier), influenciando o valor da média (Figuras 4 e 5). Encontrou-se o total de 145 espécies nos 47 ha estudados, com uma variação de 4 a 45 espécies/ha e média de 21,6 (Figura 6). O estudo da regeneração das espécies arbóreas

\footnotetext{
${ }_{7}^{6}$ número de indivíduos de determinada espécie por hectare

7 porcentagem da densidade de cada espécie em relação ao número total de indivíduos de todas as espécies.

${ }_{9}^{8}$ porcentagem de parcelas que apresentam determinada espécie.

9 soma total das frequiências absolutas, para cada espécie.

${ }_{10}^{10}$ soma das áreas basais $\left(\mathrm{m}^{2}\right)$ dos indivíduos de uma mesma espécie, por hectare

${ }^{11}$ porcentagem da dominância de cada espécie em relação à área basal total
} 
foi realizado em 16 propriedades distribuídas nos estados de Goiás e Minas Gerais (Figura 2). Encontrou-se ao todo 660 indivíduos regenerantes (total de 1,28 ha amostrados), sendo que, em média, as pastagens apresentaram o equivalente a 516 indivíduos /ha, com variação de nenhum até 1538 indivíduos/ha. Dentre as pastagens que havia regenerantes, o número de espécies variou de duas até 26 nas parcelas de 800 $\mathrm{m}^{2}$, sendo que no total da área inventariada, considerando as 16 propriedades estudadas (1,28 ha), encontrou-se 53 espécies.

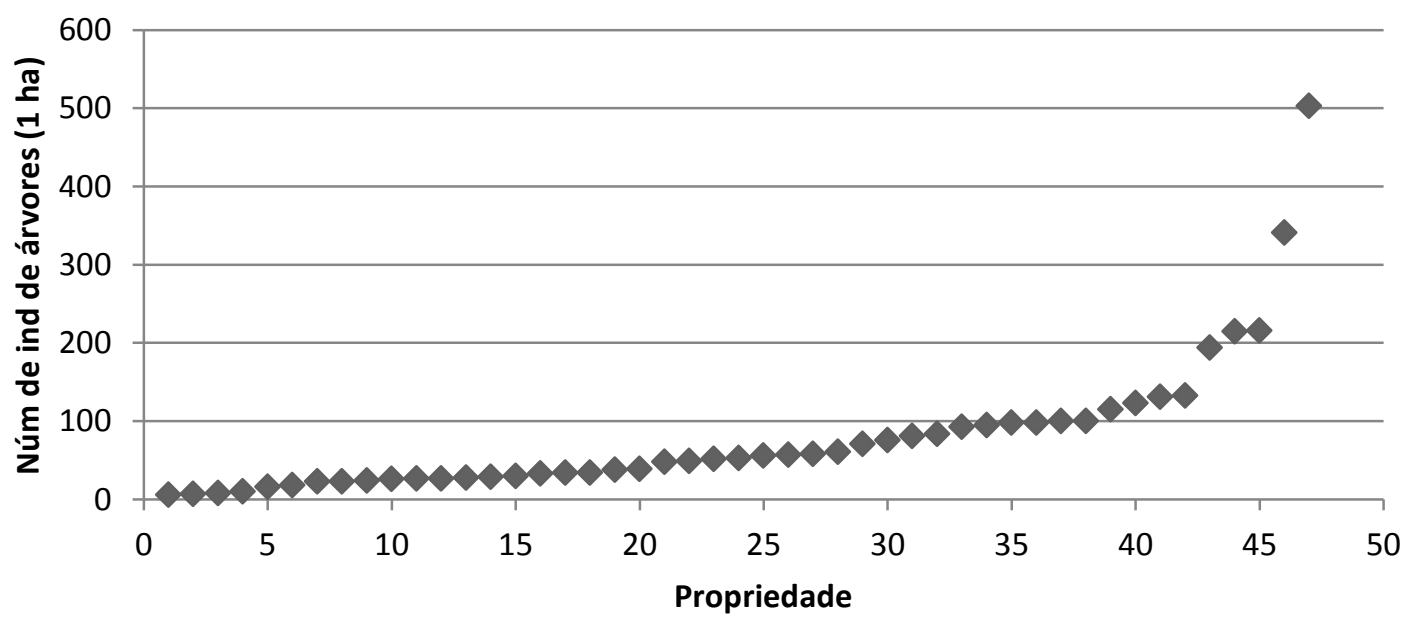

Figura 4: Número de indivíduos arbóreos com DAB > $5 \mathrm{~cm}$ em um (01) ha de pastagem em cada uma das 47 propriedades estudadas. 

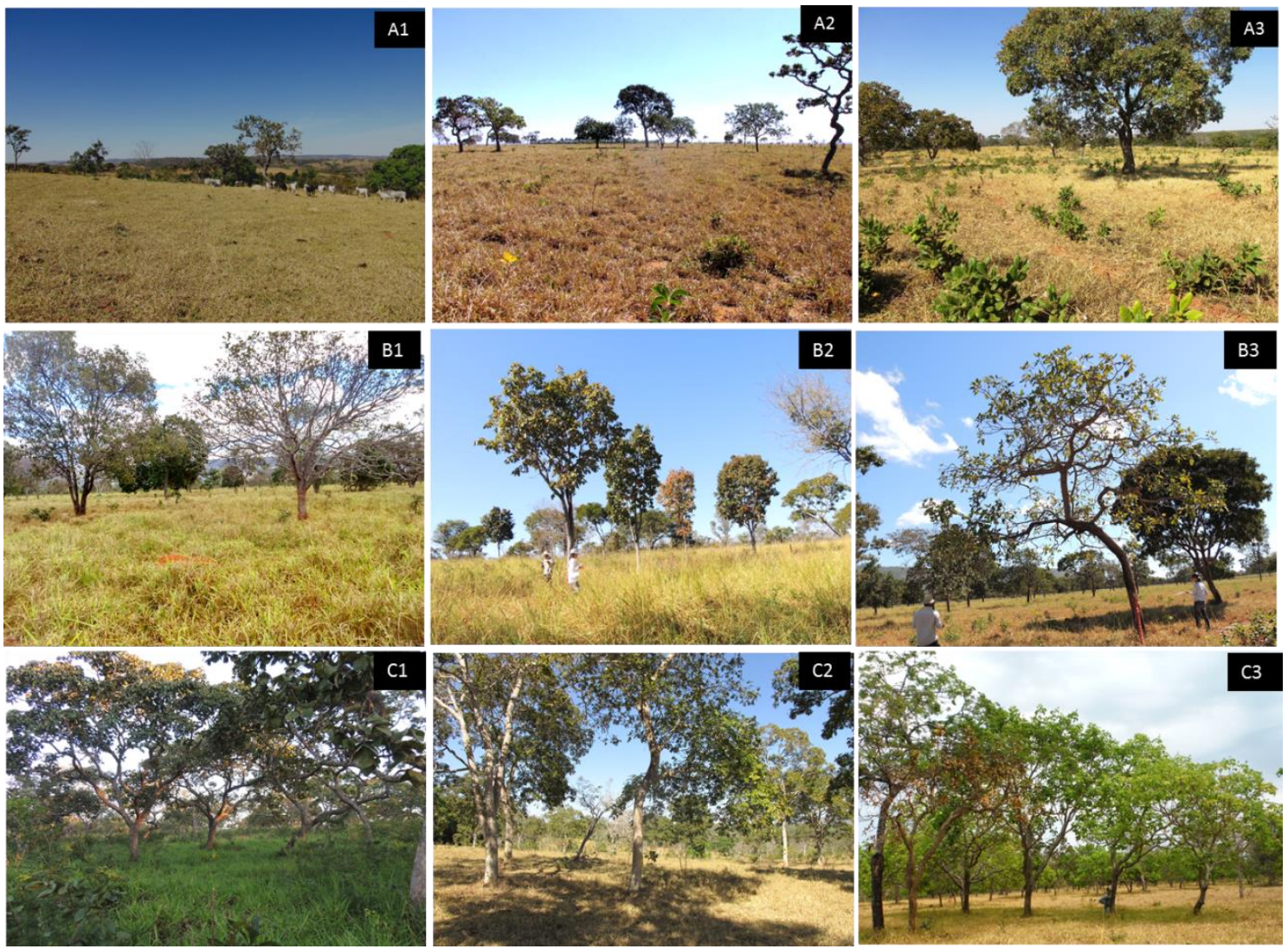

Figura 5: Pastagens arborizadas com espécies nativas do cerrado levantadas no presente estudo com três gradientes de densidade de árvores: a) baixa (até 20 árvores/ ha); b) intermediaria (entre 20 e 60 árvores/há); c) alta (acima de 60 árvores/ ha)

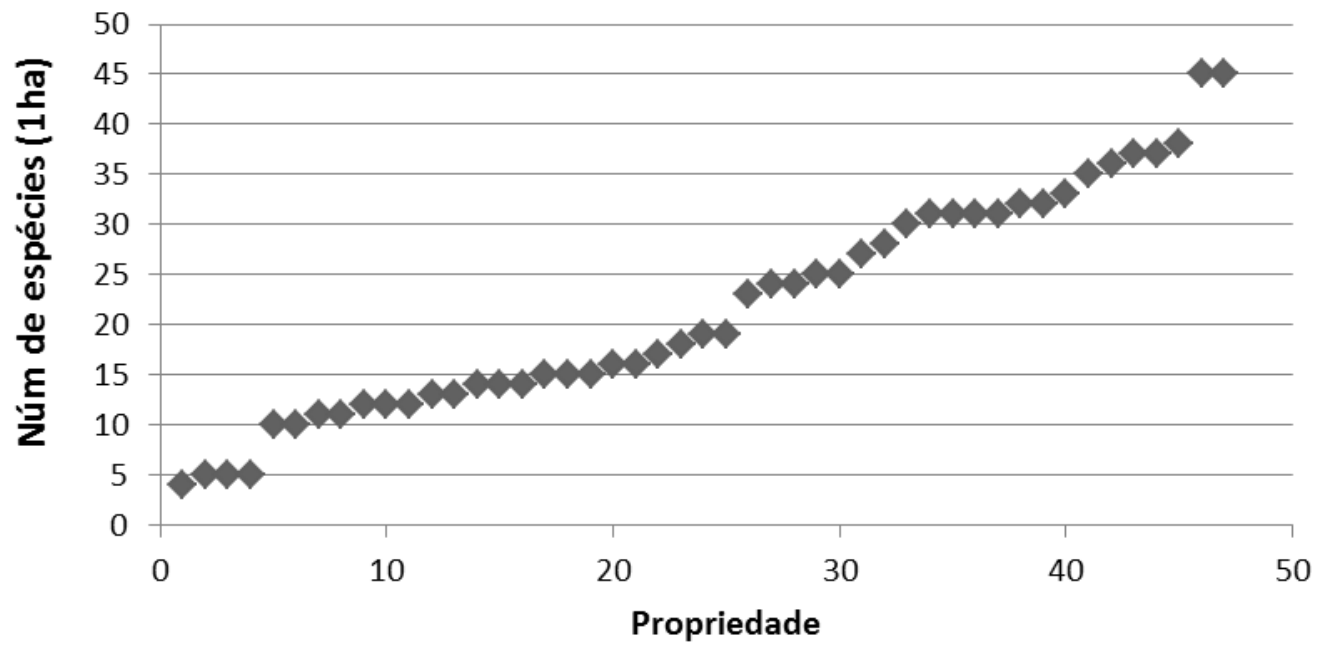

Figura 6: Riqueza arbóreas em um (01) ha de pastagem em cada uma das 47 propriedades estudadas. 
O DAB médio de todos os indivíduos inventariados foi de $20,8 \mathrm{~cm}$ (desvio padrão de 15,3) com diâmetros da base variando de 5 a $146 \mathrm{~cm}$ (Figura 7). As árvores possuem seus diâmetros concentrados nas menores classes, 70\% dos indivíduos apresentam diâmetro de até $25 \mathrm{~cm}$; outros $25 \%$ possuem DAB entre 26 e $45 \mathrm{~cm}$; e apenas $5 \%$ com diâmetros acima de $45 \mathrm{~cm}$. No presente estudo foram encontrados 73 indivíduos mortos (1,9\%), a maioria deles nas menores classes de diâmetro (21\% eram menores do que 15 $\mathrm{cm} ; 56 \%$ entre 15 e $30 \mathrm{~cm}$; e $23 \%$ entre 30 e $45 \mathrm{~cm})$. Os regenerantes apresentaram diâmetro médio de 22 milímetros (DP 30) e altura média de 52 cm (DP 39).

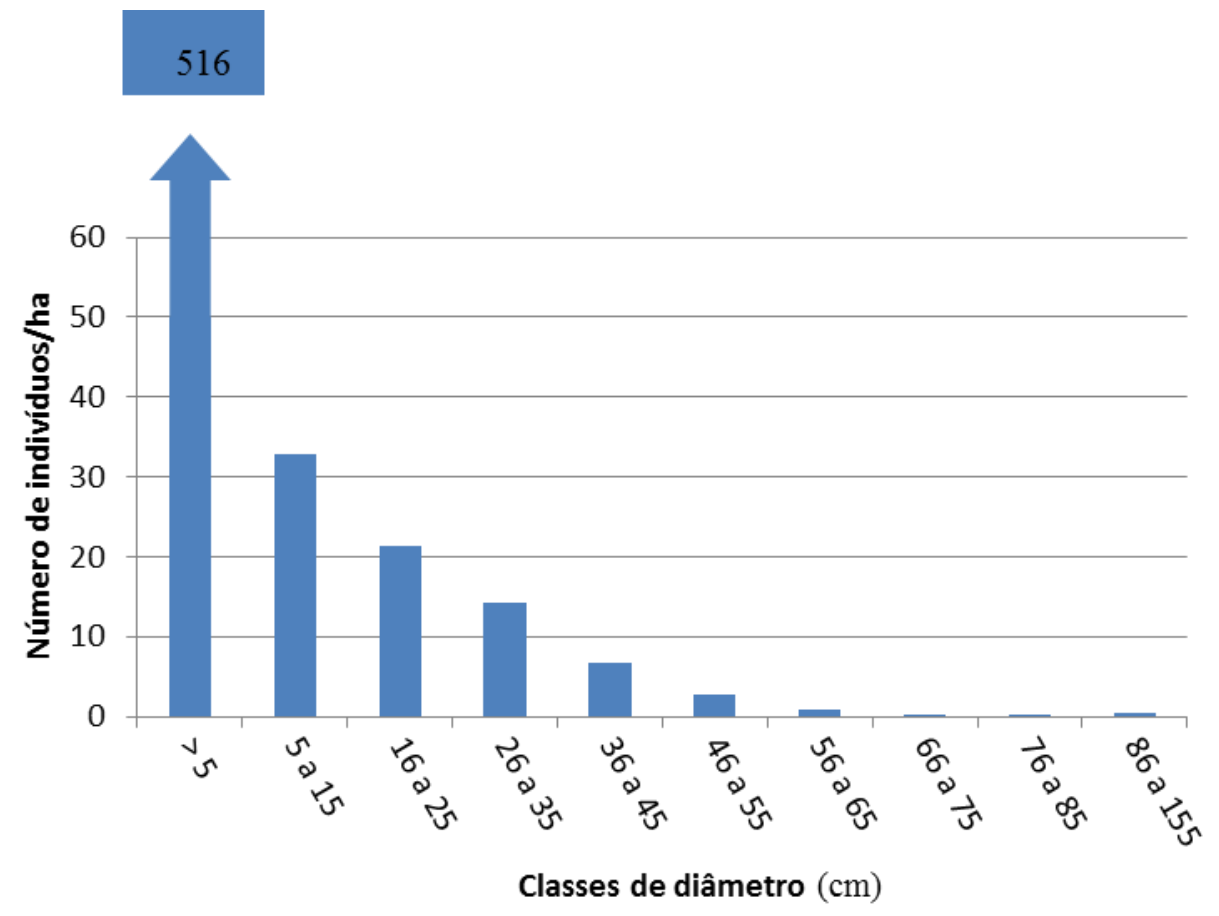

Figura 7: Média da frequência das classes de diâmetro por ha, dos indivíduos inventariados em 47 pastagens arborizadas no Cerrado, incluso os regenerantes (diâmetro $<5 \mathrm{~cm}$ ) amostrados em 16 pastagens.

\section{- Análise florística nas pastagens}

Os 3781 indivíduos arbóreos inventariados pertenciam a 145 espécies, 90 gêneros ${ }^{12}$ e $42^{13}$ famílias (Anexo 2). As espécies que mais se destacaram em número de indivíduos

\footnotetext{
${ }^{12}$ Dado exclui 4 espécies que não foram identificados o gênero, sendo que 3 delas identificou-se a família.

${ }^{13}$ Dado exclui uma coleta botânica que não foi identificada a família
} 
foram Caryocar brasiliense (12\%), Qualea grandiflora (6,7\%) e Bowdichia virgilioides (6,2\%). O número total de indivíduos de cada espécie nas pastagens (47 ha) variou de 1 a 454. As 10 espécies mais abundantes (6,9\% das espécies encontradas) representam $52,8 \%$ do total de indivíduos registrados. Trinta e oito espécies $(26,2 \%)$ apresentaram apenas um indivíduo. As famílias com maior número de espécies foi Fabaceae (33 sp), seguida de Malvaceae (10 sp), Apocynaceae e Bignoniaceae (cada uma com 7 sp).

Caryocar brasiliensis apresentou o maior IVI, com valores superiores para densidade, dominância e frequencia, seguido por Pterodon spp, Bowdichia virgilioides e Dipteryx alata. Pode-se observar que cada um dos parâmetros do IVI contribui com proporções bastante distintas em cada espécie. Por exemplo, a dominância de Sucupira branca se sobressai, enquanto para Sucupira preta e, principalmente, para Pau terra grande, percebe-se elevada contribuição da densidade.

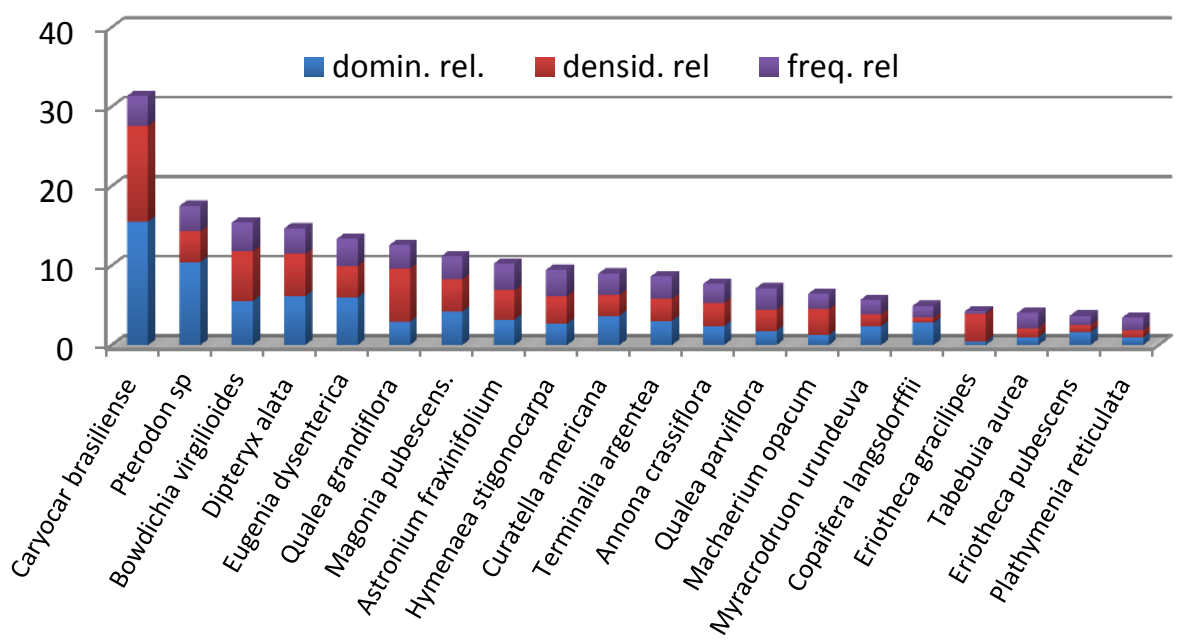

Figura 8: Índice de valor de importância das 20 principais espécies encontradas em pastagens arborizadas de 27 propriedades localizadas no Cerrado.

Os indivíduos regenerantes estão distribuídos em 56 espécies, 46 gêneros e 26 famílias. As espécies mais importantes segundo somatório da densidade relativa e frequência relativa foram: Eugenia dysenterica, Casearia sylvestris e Machaerium opacum, porém, a primeira com valor bastante superior às demais. 


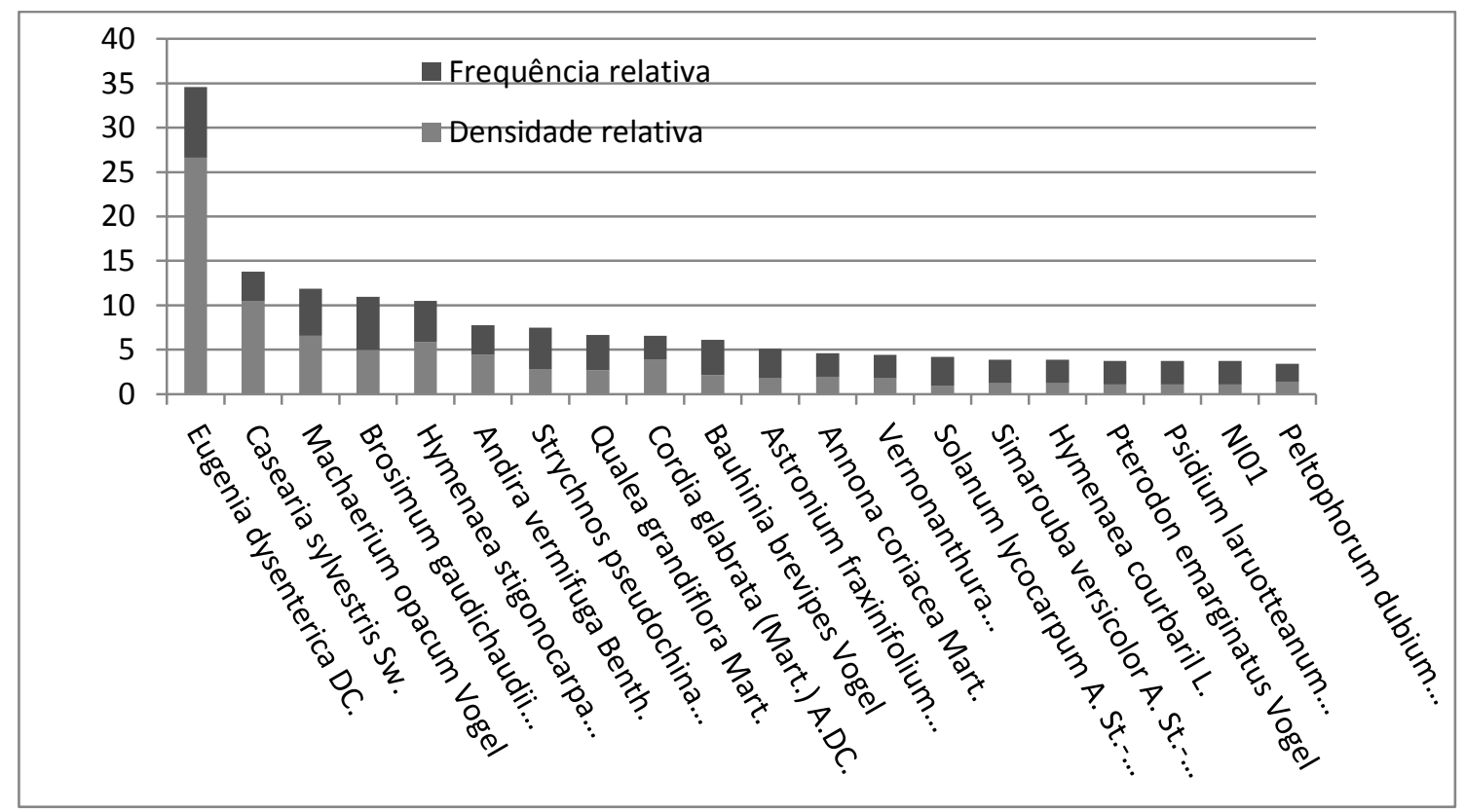

Figura 9: Representação das 20 espécies arbóreas regenerantes com maior somatório de densidade e frequência encontradas em pastagens arborizadas de 16 propriedades localizadas na área core do Cerrado.

\section{Relações do tipo de pecuarista com as árvores nas pastagens}

O gradiente de densidade de árvore e regenerantes e possivelmente de riqueza de ambos estratos pode estar relacionado à renda do pecuarista e ao nível de intensificação técnica. Para averiguar esta suposição, o tamanho da propriedade (Figura 10) e o número de animais (Figura 11) foram usados como estimadores de renda dos pecuaristas. O uso de adubo (Figura 12), a quantidade de animais por hectare (Figura 13) e a soma destas duas variáveis serviram de estimadores do nível de intensificação técnica.

Ao observar a distribuição dos pontos, para os diferentes estimadores de renda, observase que os pecuaristas com menor renda apresentam uma grande amplitude de densidade e riqueza de árvores e regenerantes, ou seja, podem ter poucas ou muitas. Mas à medida que os pecuaristas são mais capitalizados esta amplitude diminui tendendo a valores inferiores. 


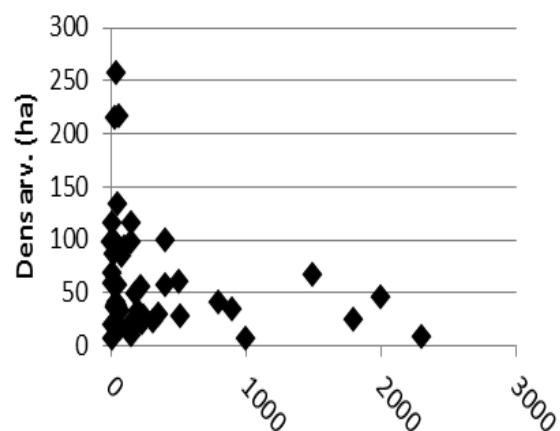

Num. animais

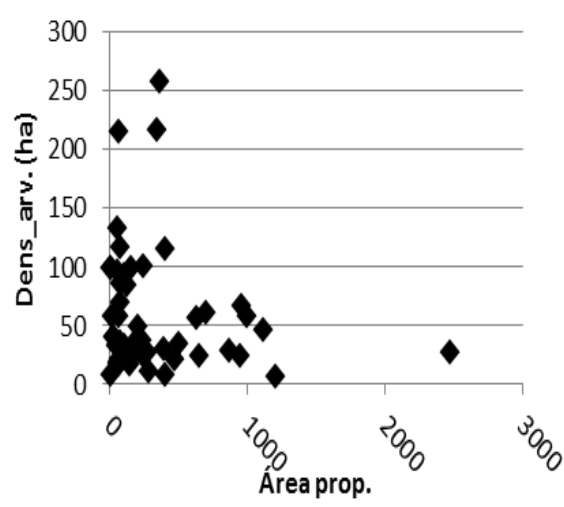

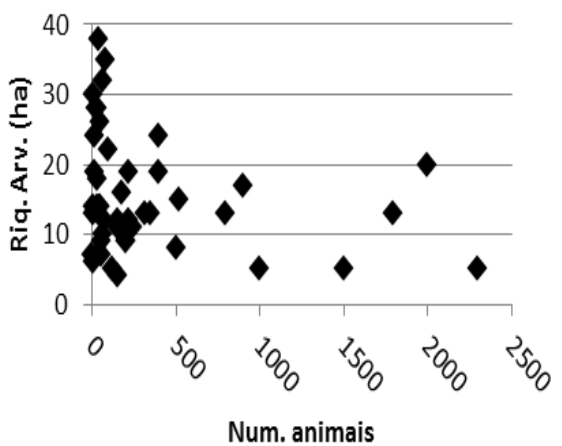

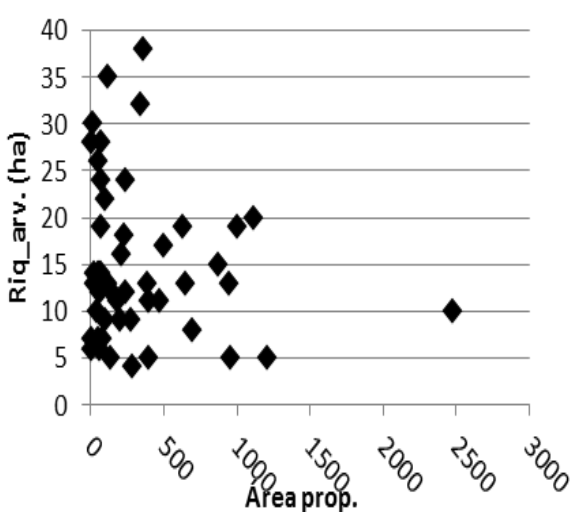

Figura 10: Correlação entre a densidade e riqueza de árvores em pastagens do Cerrado com estimadores de renda dos proprietários (número de animais, gráficos acima e área da propriedade, gráficos abaixo). 


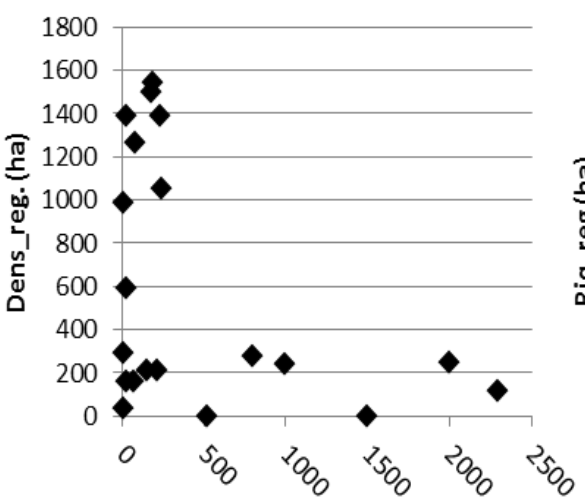

Num. animais

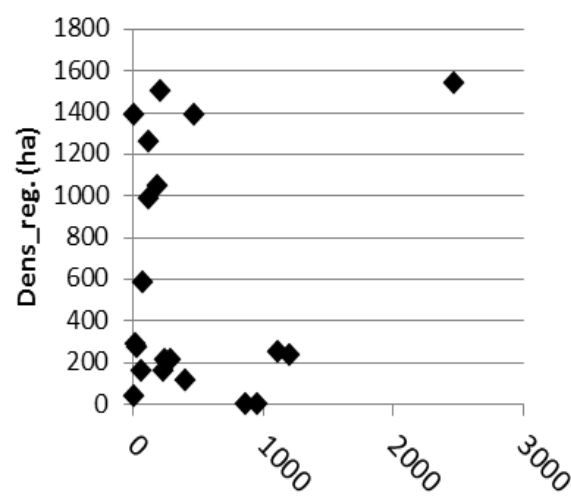

Área prop.

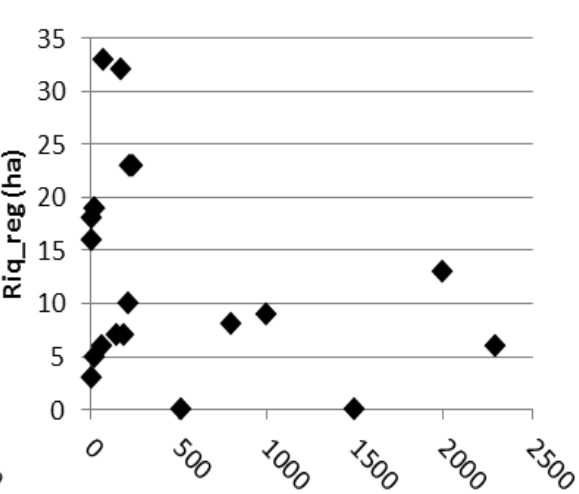

Num. animais

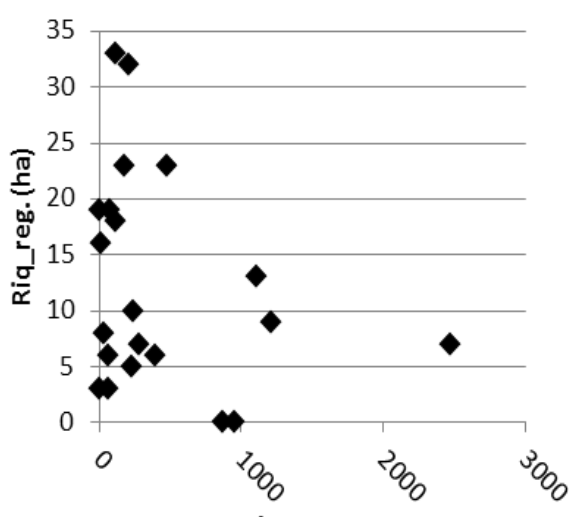

Área prop.

Figura 11: Correlação entre a densidade e riqueza de regenerantes arbóreos em pastagens do Cerrado com estimadores do nível de intensificação técnica dos proprietários (número de animais, gráficos acima e área da propriedade, gráficos abaixo).

O nível de intensificação técnica das propriedades (figura 12) parece ter padrão similar ao ocorrido com a renda dos pecuaristas em relação à densidade e riqueza de árvores. Ou seja, pecuaristas com maior intensificação técnica têm menor amplitude de situações, variam de poucas a um valor intermediário, mas não alcançam elevados níveis de densidade e riqueza de árvores em suas pastagens. Porém, para os indivíduos regenerantes foi diferente (figura 13), propriedades com diferentes níveis de intensificação técnica têm uma grande amplitude de densidade e riqueza de indivíduos regenerantes. 

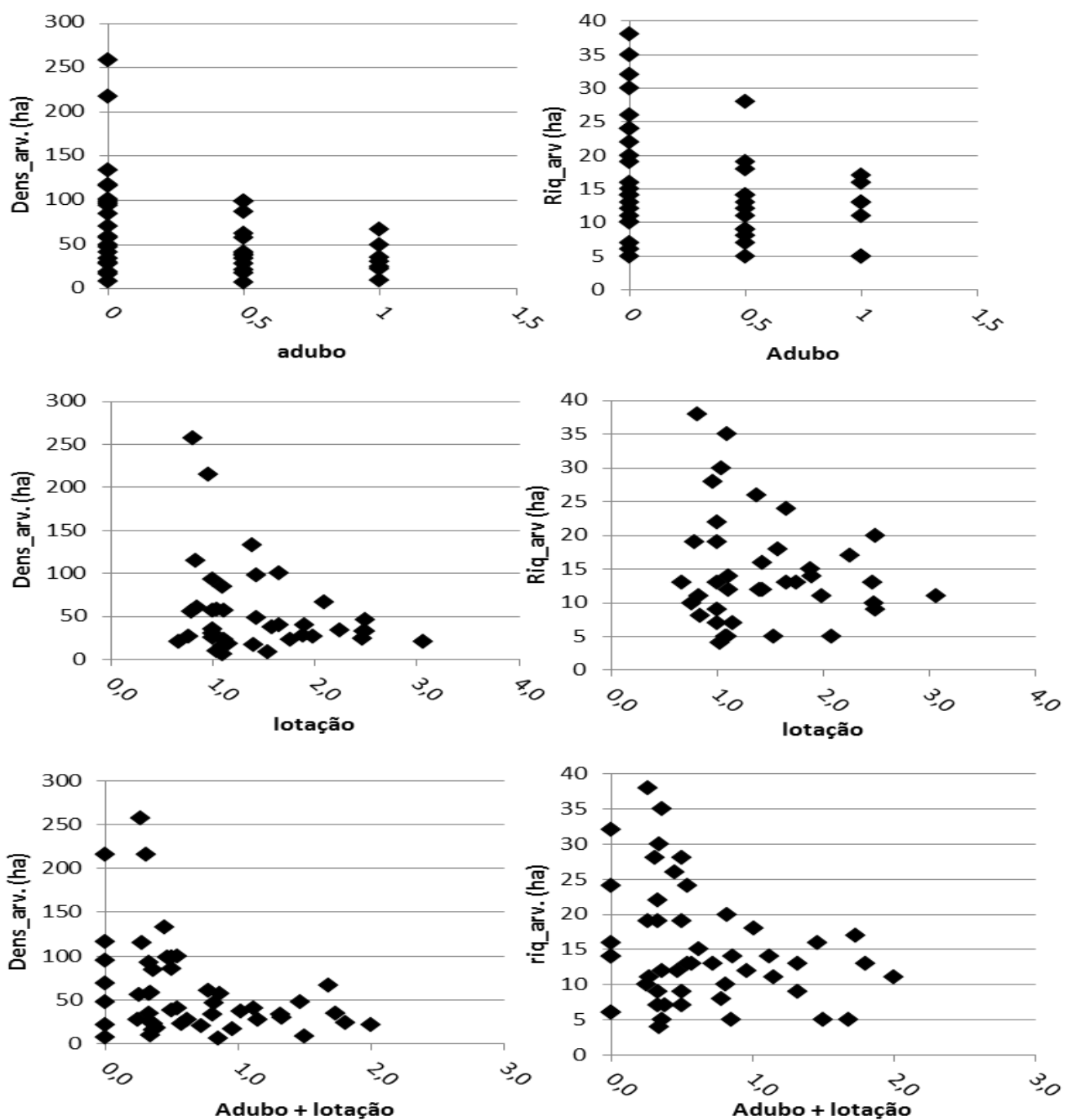

Figura 12: Correlação entre a densidade e riqueza de árvores em pastagens do Cerrado com a nível de intensificação técnica das propriedades utilizando como estimadores a utilização de adubo (0:nunca usou; 0,5:raramente; 1:sempre que necessário), a taxa de lotação animal e a soma destas duas variáveis. 

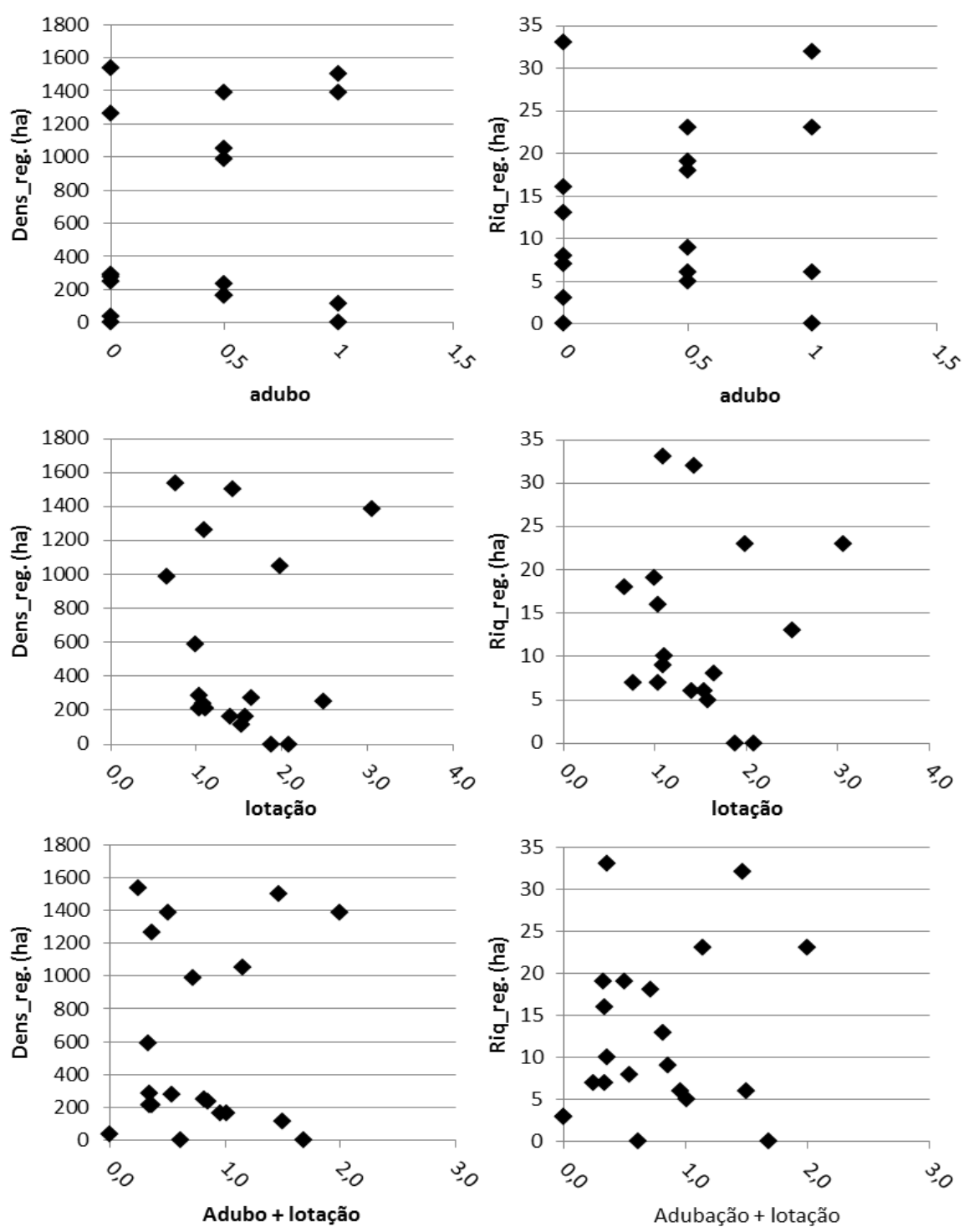

Figura 13: Correlação entre a densidade e riqueza de regenerantes arbóreos em pastagens do Cerrado com nível de intensificação técnica das propriedades, utilizando como estimadores o uso de adubo (0: nunca usou; 0,5:raramente; 1:sempre que necessário), a taxa de lotação animal e a soma destas duas variáveis.

Existem diferentes opiniões e variações de resultados experimentais sobre a influência das árvores no capim em SSP. Esta questão demostra estar associada não apenas às características das espécies arbóreas e de gramíneas presentes nas pastagens, mas também à quantidade total de árvores e animais por hectare. Na presente pesquisa, para os locais amostrados, não foi verificada influencia desta natureza (Figura 14), de acordo com a análise da correlação de Pearson $(\mathrm{r}=0,11 ; p=0,66)$. Ou seja, os dados aqui analisados contrariam resultados de que pastagens que possuem poucas árvores tendem a causar uma influencia negativa no capim sob suas copas, devido ao excesso de animais por longos períodos, em poucas áreas sombreadas que tornam-se compactadas 
(BRÁZ et al., 2003; FERREIRA, 2010). As áreas onde coletou-se os dados de cobertura de capim (Figura 2) apresentavam todas no mínimo 16 árvores/ ha, isso pode ter influenciado o resultado da fraca correlação. Seria interessante realizar nova análise que inclua dados de pastagens com menos árvores.

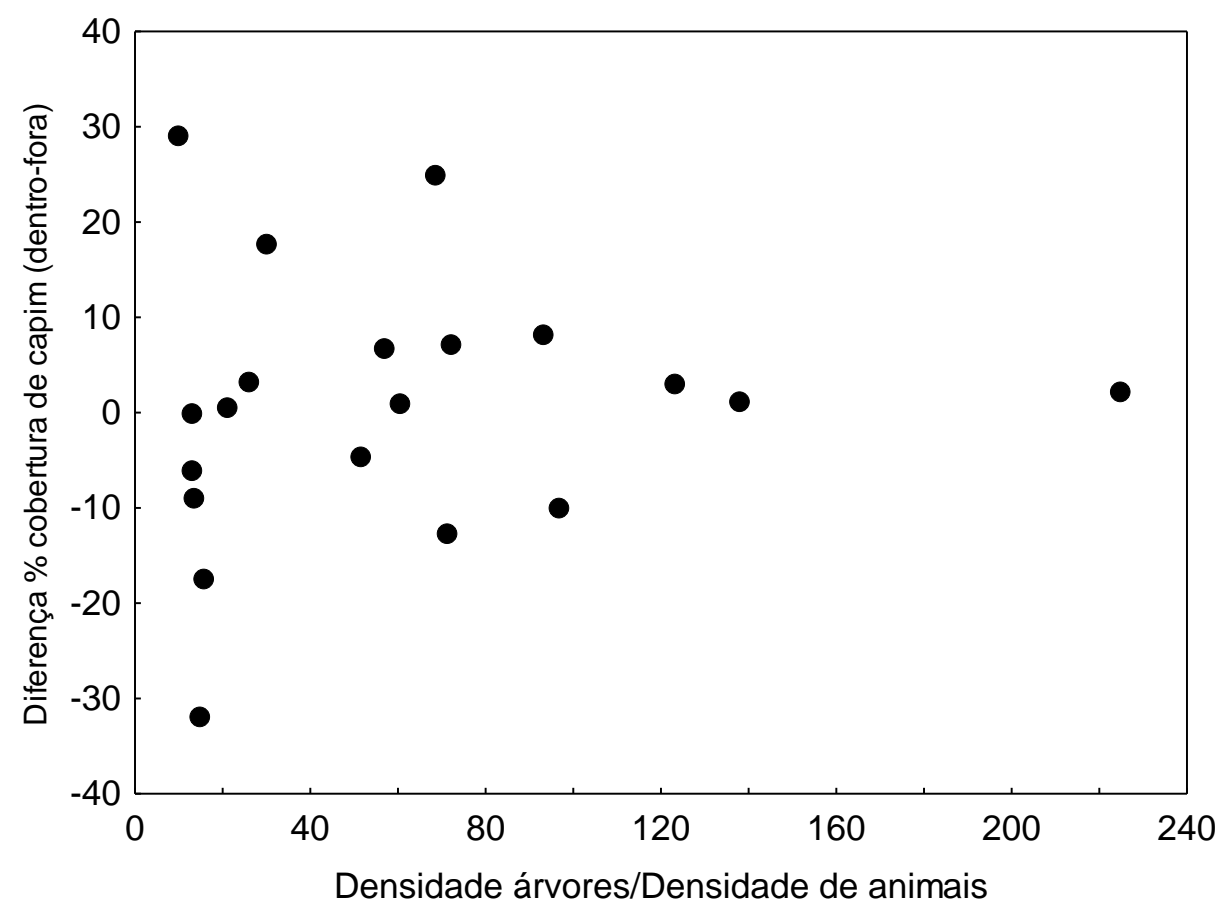

Figura 14: Demonstração da não existência de houve correlação significativa (correlação de Pearson, $r=0,11 ; p=0,66$ ) entre a razão da densidade de árvores por animais e a diferença percentual de cobertura de capim sob a copa e a pleno sol.

\section{Motivações e desafios para ter árvores nas pastagens}

Após ouvir as respostas dos 51 entrevistados, elas foram divididas em 25 sub-categorias e agrupadas em 10 categorias temáticas (Tabela 1). Cada agricultor citou várias motivações ou vantagens para ter árvores nas pastagems (média de 5 argumentos, variando 3 a 16); por isso a soma dos percentuais é superior a 100\%. As respostas mais citadas foram: fazer sombra para o gado, em primeiro lugar (86\%); deixar o capim mais verde, em segundo lugar (63\%); em seguida, com o mesmo percentual (45\%), ter uma reserva de madeira e deixar o solo mais úmido. 
Tabela 1: Motivações dos 51 pecuaristas entrevistados para ter árvores na pastagem, dividas em categorias com o respectivo percentual do número total de pecuaristas que a citaram e a ordenação das respostas mias citadas

\begin{tabular}{|c|c|c|c|}
\hline Categoria & Sub-categoria & $\%$ & $\begin{array}{l}\text { Ranking das } \\
\text { respostas } \\
\text { mais citadas }\end{array}$ \\
\hline \multirow{5}{*}{$\begin{array}{l}\text { benefício } \\
\text { para o capim }\end{array}$} & capim mais verde & 63 & 2 \\
\hline & sombra & 32 & 6 \\
\hline & mais resistente & 13 & 16 \\
\hline & produz mais & 11 & 19 \\
\hline & Rebrota mais rápido & 11 & 20 \\
\hline \multirow{4}{*}{$\begin{array}{l}\text { Benefício para } 0 \\
\text { gado }\end{array}$} & Sombra & 86 & 1 \\
\hline & Produz mais & 8 & 22 \\
\hline & Fornece alimento & 8 & 23 \\
\hline & Abrigo (chuva) & 22 & 10 \\
\hline \multirow[t]{2}{*}{ Produto madeireiro } & madeira & 45 & 3 \\
\hline & lenha & 10 & 21 \\
\hline $\begin{array}{ll}\begin{array}{l}\text { Produto } \\
\text { madeireiro }\end{array} & \text { não } \\
\end{array}$ & fruta & 22 & 7 \\
\hline \multirow[t]{3}{*}{ Benefício para solo } & adubação & 22 & 8 \\
\hline & mais úmido & 45 & 4 \\
\hline & proteger & 22 & 9 \\
\hline \multirow[t]{3}{*}{ Ambiental } & preservar & 33 & 5 \\
\hline & mais chuva & 14 & 15 \\
\hline & $\begin{array}{l}\text { atrair/proteger } \\
\text { selvagens }\end{array}$ & 18 & 12 \\
\hline \multirow[t]{2}{*}{ Produção } & equilíbrio do sistema & 6 & 24 \\
\hline & quebra vento & 12 & 17 \\
\hline \multirow[t]{2}{*}{ Bem estar humano } & beleza & 16 & 13 \\
\hline & microclima & 16 & 14 \\
\hline Ética & futuras gerações & 18 & 11 \\
\hline Norma & exigência ambiental & 12 & 18 \\
\hline
\end{tabular}

Quando perguntado aos pecuaristas do Cerrado sobre os principais desafios e dificuldades deste tipo de sistema, a reposta mais frequente foi não achar dificuldade alguma (33\% dos entrevistados). Os desafios mais citados foram ligados ao tema da dificuldade de mecanização, seja devido ao maquinário considerado impróprio (25\% dos entrevistados); ao maior tempo para formar ou manejar tais sistemas (ex: gradear e roçar: 21\%); a necessidade roçadas manuais de "limpeza" das pastagens (17\%); a falta 
de tratoristas capacitados (10\%); o manejo considerado mais caro (3\%) e a dificuldade de rotacionar com culturas agrícolas (3\%), já que estas exigem maior frequência de ações mecanizadas. Outras questões que surgiram com baixa frequência foi a dificuldade de conseguir financiamento para este tipo de sistema (3\%) e problemas para depois conseguir autorização para usar algumas madeiras que foram deixadas (3\%).

\section{A formação do SSP pelos pecuaristas}

A estrutura e riqueza das árvores nas pastagens são reflexo do histórico de uso e manejo da área, assim como da forma como foram realizados os primeiros desmatamentos seletivos do cerrado para formar estas pastagens. Os pecuaristas fazem a seleção das árvores que compõe os SSP observando alguns critérios como as características das árvores, sua disposição na pastagem e os produtos que elas geram (Tabela 2). Os entrevistados mencionaram 15 tipos de argumentos agrupados em quatro categorias.

Tabela 2: Critérios adotados pelos pecuaristas para seleção das árvores que mantem na pastagem durante o desmatamento seletivo do cerrado $(n=33)$.

\begin{tabular}{lll}
\hline Categoria & Sub-categoria & \% \\
\hline Características & Grandes & 82 \\
das árvores & Bonitas (sadia) & 24 \\
& Retas ou "Linheiras" & 24 \\
& Adultas (exclui as velhas) & 9 \\
& Finas (também) & 9 \\
& Vivem muito & 6 \\
& Não prejudicam o pasto & 3 \\
\hline Disposição & na pasparamento & 27 \\
pastagem & trator & \\
& Pequenos aglomerados & 15 \\
& Bem distribuídas & 15 \\
\hline Produtos & Madeira nobre & 73 \\
& Frutíferas & 52 \\
& Flores & 9 \\
& Remédios & 6 \\
\hline Outros & Exigidas pelo órgão & 18 \\
& ambiental & \\
\hline
\end{tabular}

Dentre os pecuaristas que mencionaram que as árvores deixadas nas pastagens deveriam ser grandes, $22 \%$ especificaram que as elas deveriam ser altas e outros $22 \%$ falaram sobre elas terem copas grandes para gerarem bom sombreamento para os animais. Nenhum pecuarista citou ambos argumentos. As duas características seguintes mais citadas são sobre gerar produtos úteis, $73 \%$ falaram que têm preferencia em deixar 
árvores que geram madeiras de uso nobre e 52\% mencionaram árvores que produzam frutos comestíveis. Os outros 12 argumentos foram citados por percentual inferior a $50 \%$ dos pecuaristas.

A quantidade de árvores em cada sistema varia bastante e, normalmente, depende das decisões dos proprietários baseadas em suas experiência e percepções. Mas, nem sempre a situação atual é considerada a ideal. Assim, quando perguntados se achavam que a quantidade de árvores em suas pastagens era ideal, ou melhor seria se tivessem quantidade inferior ou superior, $44 \%$ disseram que como está é o ideal, $41 \%$ declararam que o ideal era ter mais, e 15\% mencionaram que se tivesse menos árvores seria melhor.

\section{O manejo do sistema}

Uma prática de manejo frequente neste tipo de sistemas é a denominada "limpeza da pastagem" ou "bater pasto", que visa eliminar plantas que possam estar atrapalhando o capim como: ervas, arbustos e regenerantes de árvores. O método adotado neste manejo é bastante variado quanto à frequência realizada, aos instrumentos utilizados, à época mais adequada. A maioria (52\%) dos pecuaristas declararam que fazem este tipo de roçada anualmentete, $26 \%$ a cada dois anos e apenas $8 \%$ demoram mais de dois anos sem roçar, e ainda, $13 \%$ disseram que não fazem este procedimento, pois não precisa já que poucas plantas além do capim nascem ou regeneram na pastagem. A maioria (58\%) disse que melhor época pra "limpar" o pasto é entre o fim da seca e início do período chuvoso, outros $29 \%$ pensam diferente e preferem o período entre o meio a fim do período chuvoso e uma minoria (13\%) prefere o realizar tal manejo no durante o período seco. Dentre os equipamentos, a maioria (53\%) utiliza métodos manuais (foice: $42 \%$; enxadão: $12 \%$ ), outros (21\%) usam a roçadeira acoplada ao trator, e ainda há os fazem um revezamento entre este dois métodos (23\%). Uma minoria (12\%) declarou que não costuma limpar a pastagem, pois nascem poucas plantas além do capim, e que elas não chegam a atrapalha-lo, além do que este é um procedimento oneroso.

Dentre pecuaristas que fazem a limpeza da pastagem, foi quase unanime (93\%) a declaração que, durante este procedimento, eles deixam algumas rebrotas de espécies arbóreas do seu interesse. Cada pecuarista citou, em média, duas justificativas para esta ação e o argumento mais citado (52\%) foi para repor as espécies que vão morrendo, pensando em continuar tendo árvores no futuro (Tabela 3). 
Tabela 3: Argumentos citados pelo pecuarista para manter algumas rebrotas de árvores na pastagem durante o procedimento de "limpeza" das pastagens $(n=29)$.

\begin{tabular}{ll}
\hline Categoria & \% \\
\hline Substituir as que morrem pensando & 52 \\
no futuro & 34 \\
Madeira & 28 \\
Fruta & 21 \\
Forragem & 10 \\
Ocupar espaços vazios & 21 \\
Outros & \\
\hline
\end{tabular}

Os entrevistados, quando questionados acerca das principais espécies que deixam na pastagem durante seu manejo, mencionaram (43\%) principalmente o pequi, embora muitos não especificaram as espécies, mas apenas a utilidades ou característica das árvores que priorizam (Tabela 4). A maioria dos pecuaristas (92\%) afirmou que o gado come as rebrotas destas árvores, principalmente as folhas novas no período da seca. Outra possível ação de manejo das pastagens envolvendo as árvores é a poda dos seus galhos com diferentes objetivos. Dentre 27 entrevistados que falaram acerca deste assunto, $56 \%$ dizem já terem feito podas nas árvores e $44 \%$ nunca realizaram este procedimento. A motivação dos que já podaram as árvores na pastagem foi sempre direcionada às árvores mais baixas, e com o objetivo principal $(60 \%)$ de permitir a passagem do trator durante a roçagem ou reforma da pastagem. Outras motivações citadas em menor percentual foram: podar o pequi para produzir mais $(23 \%)$; permitir o gado ficar sob as árvores (15\%); aumento da entrada de luz e melhora da ventilação sob as árvores (15\%).

Tabela 4: Espécies citadas como prioritárias na seleção das regenerantes arbóreas ou as utilidades e características observadas durante a escolha $(n=29)$.

\begin{tabular}{lllll}
\hline Espécie & $\begin{array}{l}\text { Nome } \\
\text { popular }\end{array}$ & $\%$ & Utilidade/Característica & \% \\
\hline Caryocar brasiliense & Pequi & 59 & Madeira & 21 \\
Plathymenia reticulata & Vinhático & 10 & Fruta & 10 \\
& Sucupira & & & \\
Pterodon sp & branca & 24 & Retilíneas ou "Linheiras" & 21 \\
Dipteryx alata & Baru & 31 & Outros" & 17 \\
Tabebuia aurea & Craiba & 14 & & \\
$\begin{array}{l}\text { Myracrodruom } \\
\text { urundeuva }\end{array}$ & Aroeira & & & \\
Anacardium & Caju & 10 & &
\end{tabular}


occidentale

Magonia pubescens Tingui 7

*Gerar lenha, remédio, árvores diversificadas, brotos mais grossos.

\section{Interação das árvores com o gado e o capim segundo os pecuaristas}

Conforme mencionado acima, uma grande motivação para ter árvores nas pastagens é fornecer sombra ao gado. Os pecuaristas falaram sobre a preferencia do gado pela sombra de determinadas espécies (Tabela 5). As respostas variaram de padrão, pois alguns preferiram citar as espécies, outros a característica da árvore, ou ambos os tipos de resposta.

Tabela 5: Tipo de árvore que o gado demonstra ter preferencia para ficar em baixo segundo observações dos pecuaristas $(n=28)$

\begin{tabular}{|c|c|c|c|c|c|}
\hline Categoria & & $\%$ & Espécie & Nome popular & $\%$ \\
\hline $\begin{array}{l}\text { Árvores que dão } \\
\text { sombra }\end{array}$ & mais & 61 & Caryocar brasiliense & Pequi & 43 \\
\hline $\begin{array}{l}\text { Árvores com } \\
\text { maiores }\end{array}$ & copas & 46 & Dipteryx alata & Baru & 21 \\
\hline Aleatório & & 14 & Pterodon sp & $\begin{array}{l}\text { Sucupira } \\
\text { branca }\end{array}$ & 14 \\
\hline Não reparou & & 11 & Copaifera langsdorffi & Copaíba & 11 \\
\hline \multirow[t]{2}{*}{ Perto da água } & & 7 & Ficus sp & Gameleira & 7 \\
\hline & & & & Outras $^{* *}$ & 7 \\
\hline
\end{tabular}

*Qualea sp (Pau terra) e Hymenaea stigonocarpa (Jatobá).

Uma questão importante sobre as árvores na pastagem é conhecer se as espécies são capazes de influenciar o capim sob elas, seja positiva ou negativamente. Quando perguntados acerca de alguma espécie arbórea em que o capim fica mais bonito sob sua copa, $37 \%$ dos pecuaristas citaram o pequi e $26 \%$ a sucupira, que constituíram as respostas mais frequentes. Outros preferiram falar das características que julgam influenciar (tabela 6). Por outo lado, é importante conhecer se existem espécies capazes de interferir negativamente no capim sob suas copas. Grande parte dos entrevistados citou interferência negativa da aroeira no capim (Tabela 7) e de forma mais geral citaram que árvores com copa densa e baixa podem atrapalhar seu desenvolvimrnto. 
Tabela 6: Características e espécies mencionadas pelos pecuaristas que influenciam positivamente o capim sob a copa das árvores $(\mathrm{n}=27)$.

\begin{tabular}{lclll}
\hline Característica & \% & Espécie & Nome popular & \% \\
\hline Altas & 19 & $\begin{array}{c}\text { Caryocar } \\
\text { brasiliense }\end{array}$ & Pequi & 37 \\
Não reparou & 19 & Pterodon & Sucupira branca & 26 \\
Copa rala & 7 & Dipteryx alata & Baru & 11 \\
Todas & 7 & Outras & \\
Igual (sob e fora da & & & \\
copa) & & & & \\
\hline
\end{tabular}

:Respostas citadas por apenas um entrevistado: copa com folhas pequenas, Enterolobium sp (tamboril); Tabebuia aurea (Ipê caraíba).

Tabela 7: Características e espécies mencionadas pelos pecuaristas que influenciam negativamente o capim sob a copa das árvores $(n=23)$.

\begin{tabular}{lclll}
\hline Característica & $\%$ & Espécie & $\begin{array}{l}\text { Nome } \\
\text { Popular }\end{array}$ & $\%$ \\
\hline Muito baixa & 13 & $\begin{array}{l}\text { Myracrodruom } \\
\text { urundeuva } \\
\text { Conadenanthera }\end{array}$ & Aroeira & 39 \\
Copa muito densa & 17 & $\begin{array}{l}\text { Angico } \\
\text { macrocarpa }\end{array}$ & 13 \\
Nenhuma & 9 & Magonia pubescens & Tingui & 9 \\
Não reparou & 13 & Outras ${ }^{1}$ & 13 \\
${ }^{1}$ Ficus sp (gameleira); & Copaifera langsdorffi (copaíba); Schinopsis brasiliensis \\
(braúna). & & &
\end{tabular}

Conhecimento dos pecuaristas sobre o assunto

Os pecuaristas demonstraram conhecer sobre o tema árvores nativas do cerrado dispersas em suas pastagens e suas interações com os animais e o capim. Dentre os 21 entrevistados, $71 \%{ }^{14}$ disseram que foram aprendendo ao longo dos anos de trabalho, por meio de observações e experimentações; $29 \%$ declararam que teve influencia de seus antepassados neste aprendizado; e apenas $14 \%{ }^{15}$ comentou que órgãos de assistência técnica auxiliaram na obtenção deste conhecimento.

\footnotetext{
${ }^{14} \mathrm{Um}$ entrevistado pode ter dado mais de uma resposta.

${ }^{15}$ Este percentual refere-se a três pecuaristas de uma mesma região que declararam ter sofrido influencia da assistência técnica do Centro de Agricultura Alternativa do Norte de Minas Gerais que incentiva a formação de pastagens com manutenção das árvores nativas.
} 


\section{DISCUSSÃO}

\section{Densidade e riqueza de árvores nas pastagens:}

As espécies arbóreas encontradas nas pastagens indicam alta riqueza considerando que trata-se de área produtiva da propriedade. Outros estudos relataram quantidades inferiores: 75 espécies em 42 ha na Costa Rica e 55 espécies em 240 ha na Venezuela (GRANDE et al., 2010; SOLORZANI et al., 2006). Já em estudo na Costa rica foram encontradas 199 espécies em grande amostral (237 ha), em diferentes regiões de florestas tropicais (HARVEY e HABER, 1999). Estes valores provavelmente são influenciados pela riqueza de espécies do ecossistema de origem e pela manejo dos pecuaristas.

A média de 80 árvores por ha em pastagem pode ser considerada alta quando comparada com outros estudos, por exemplo, 23 a 38 árvores / ha encontrados em pastagens da Nicarágua e Costa Rica (RUIZ et al., 2005; VILLACIS et al. 2003; GRANDE et al., 2010). Porém, é importante ressaltar que no presente trabalho, as pastagens selecionadas não foram escolhidas aleatoriamente em relação ao número de indivíduos como nas pesquisas citadas acima, aqui escolheu-se pastagens que tivessem no mínimo 5 árvores / ha e buscou-se abranger toda a amplitude de densidade existente. Provavelmente, se fosse escolhido aleatoriamente a média seria muito baixa, pois, por meio de uma análise visual ao longo das viagens de campo, pode-se perceber que predominam pastagens com pouquíssimas árvores ou sem árvores e isso varia muito de acordo com a região do Bioma Cerrado.

A grande variação de densidade de árvores nas pastagens também ocorre em outros estudos na América Central como de 5 a 146 indivíduos/ha (GRANDE et al., 2010; HARVEY e HABER, 1999). Este fato pode ser explicado pela falta de conhecimento dos pecuaristas sobre o nível ideal de sombreamento (HERVEY, 2011), e também devido às características do ambiente (solo, clima, topografia, relevo), das espécies de capim, de questões culturais ${ }^{16}$, do histórico de uso da terra ${ }^{17}$, da vegetação original, da

\footnotetext{
${ }^{16}$ Por exemplo, se manter árvores no pasto é algo bastante praticado em toda região e se os antepassados faziam deste modo, além de informações (mitos ou verdades) difundidas em conversas informais entre os próprios pecuaristas da região que acabam influenciando as decisões da quantidade ideal de árvores nos pastos.

${ }_{17}$ As atividades já realizadas naquela área ao longo do tempo, por exemplo, se já foi usada como área de cultivo ou se foi recentemente formada a partir de um cerrado nativo pode interferir nas possibilidades de quantas árvores ter nesta área produtiva.
} 
capacidade de regeneração das árvores e da possibilidade de enriquecer o sistema por meio de plantios.

\section{Relações do tipo de pecuarista com as árvores nas pastagens}

A variação de densidade e riqueza de árvores ou de regenerantes nas pastagens pode ser percebida por uma observação atenta das paisagens em diferentes regiões do bioma Cerrado. As avalições de campo do presente estudo puderam confirmar e especificar tais variações, mas resta compreender o que pode influenciar tamanha variação. Uma suposição é que a renda do pecuarista, logo, sua capacidade de investimento na pecuária podem influenciar esta realidade. O nível de intensificação técnica adotado influencia a forma de manejo, como por exemplo, o uso de adubação química, maquinário para roçar ("limpar") a pastagem, e a taxa de lotação animal adotada. Observou-se que os pecuaristas com menor renda apresentam uma grande amplitude de densidade de árvores, ou seja, podem ter poucas ou muitas, porém, os que são mais capitalizados tendem a diminuir a amplitude de densidade de árvores, a quantidade passa a variar de poucas até um número mediano (Figura 15). O mesmo parece ocorrer para as espécies arbóreas regenerantes. Uma justificativa para tal resultado é que à medida que as árvores estão mais adensadas tornam as ações de manejo menos sistemáticas, o que dificulta sua adoção pelo pecuarista de maior renda que apresenta alta intensificação técnica. Por exemplo, muitas árvores podem dificultar ou impedir o trânsito de máquinas, ou para viabilizar este processo pode ser necessário poda das árvores, que constitui um manejo cuidadoso e não sistemático. 


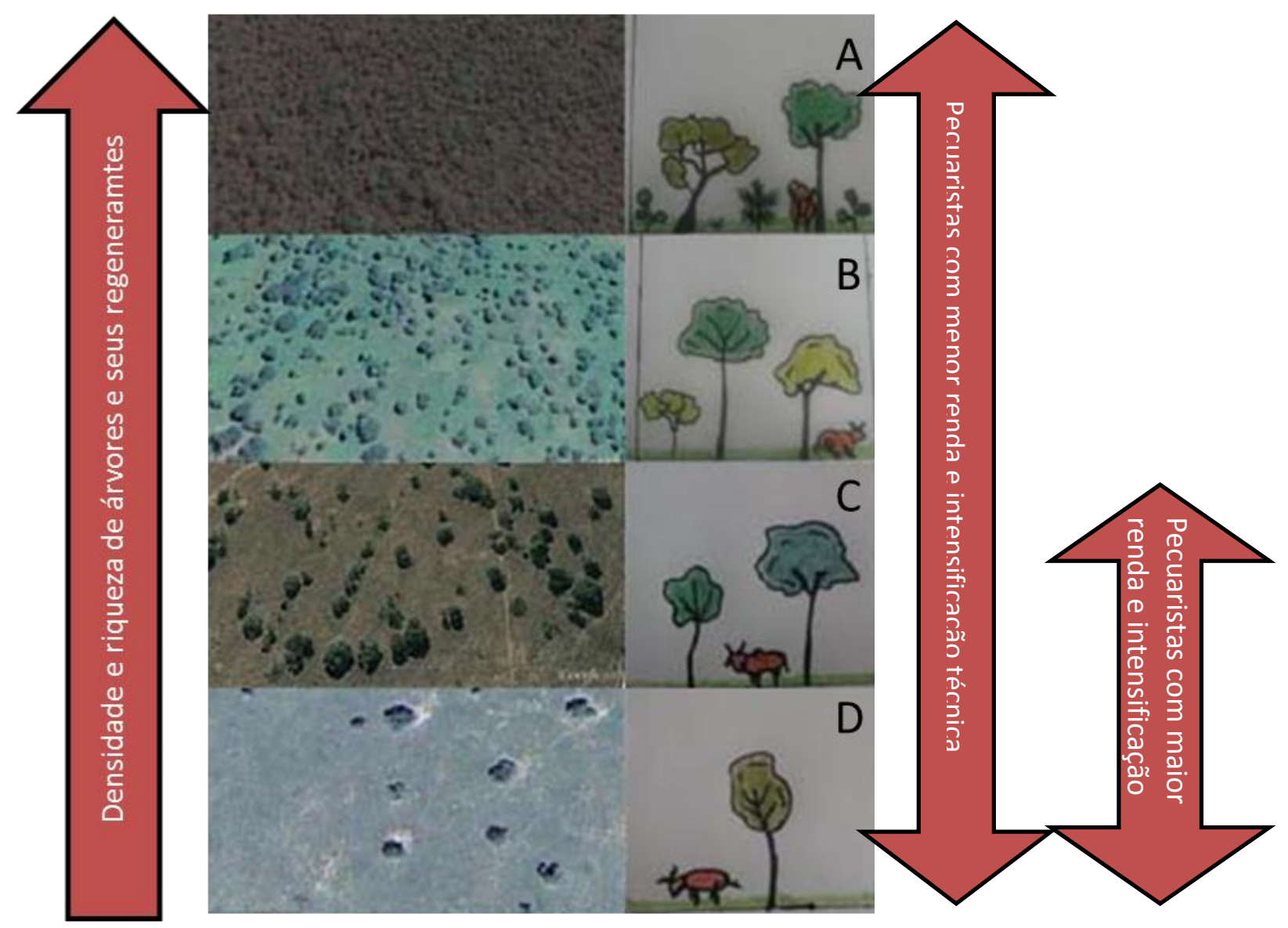

Figura 15: Representação esquemática das diferentes densidades e riqueza de árvores nativas presentes em pastagens na zona core do Bioma Cerrado e sua relação (setas) coma renda do pecuarista e nível de intensificação técnica da pastagem. A:Pastagem nativa, sem plantio de gramínea africana, e sem desmatamento significativo B: Pastagem formada pelo desmatamento seletivo de árvores nativas e plantio de gramíneas africanas mantendo grande quantidade de árvores. C: Idem ao B, porém com mediana quantidade de árvores. D: Idem ao $\mathrm{B}$ e $\mathrm{C}$, porém com poucas árvores na pastagem.

Este resultado ressalta que pastagens com árvores nativas podem ser feitas de diferentes maneiras, são adaptáveis a pecuaristas com características bastante distintas, sejam eles pequenas ou grandes proprietários, que usam insumos ou não, que adotam diferentes taxas de lotação animal. O que é determinante para estes pecuaristas aderirem a este tipo de sistemas que conserva a biodiversidade local ainda não está claro e precisa ser melhor investigado. Pecuaristas com intensificação técnica e com maior rentabilidade também optam em ter árvores nativas em seus pastos. Esta informação abre a possibilidade de que um grande público poderia adotar este tipo de sistema, principalmente onde as pastagens mantém a capacidade de regeneração, adaptando-as às suas realidades tecnológicas, econômicas e também culturais. 


\section{Análise florística}

\section{- As espécies mais importantes}

As espécies de maior IVI encontradas no presente trabalho são conhecidas pelos pecuaristas entrevistados por gerar frutos comestíveis e/ou madeiras de qualidade, além de atingir grande porte, com copas amplas, capazes de gerar sombra para o gado, ou seja, podem ser chamadas de espécies multi-propósito (vide capítulo 3). Dentre as 20 espécies de maior IVI (Figura 8), as únicas que não foram citadas como de grande utilidade foram Qualea grandiflora e Curatella americana, porém se destacam pela grande densidade e frequência no cerrado lato sensu (FRANÇOSO, 2014; BRIDGEWATER, 2004; RATTER, 2003).

A predominância de Caryocar brasiliense em relação às outras espécies, possivelmente, é reflexo da sua valorização pela população do Cerrado, devido principalmente ao seu fruto. Este fato pode ser constatado por ser este o Produto Florestal não Madeireiro (PFNM) mais comercializado no Cerrado (AFONSO e ÂNGELO, 2009, IBGE, 2015). A espécie também possui madeira de alta qualidade (LORENZI, 2002), além de ter ampla distribuição e ocorrer em elevadas densidades (FRANÇOSO, 2014; RATTER, 2003). Cabe ressaltar que no estado de MG existe desde 1992 a Lei ${ }^{\circ} 10.883^{18}$, que declara o pequizeiro imune ao corte. Os dados mostram que o estado de MG apresenta $7,5 \%$ a mais de pequi por propriedade do que GO, este resultado pode ser influência desta lei.

Dipteryx alata, com o segundo maior IVI nas pastagens estudadas, também é árvore muito valorizada por seus frutos que são comercializados para consumo humano (principalmente sua amêndoa) e possui madeira de utilização nobre. Além disso, seus frutos são comestíveis e nutritivos para o gado, possuem altos índices de proteína (TOGASHI \& SGARBIERI, 1994), é uma árvore muito produtiva, que gera cerca de $150 \mathrm{Kg}$ de frutos, ou seja, uma importante fonte de alimentação, principalmente porque a queda dos frutos maduros ocorre entre os meses de agosto e outubro (CARRAZA e ÁVILA, 2010), auge da estação seca, período de escassez de forragem no Cerrado. Por

\footnotetext{
${ }^{18}$ Esta norma foi pouco alterada pela lei Lei $\mathrm{n}^{\mathrm{o}}$. 17.682, de 25 de julho de 2008 e mais recentemente pela lei Lei $\mathrm{n}^{\mathrm{o}} 20.308$ de 2012 que reduziu as restrições para o corte do pequizeiro estabelecendo que quando a manutenção da espécie no local dificultar a implantação de projeto agrossilvipastoril, mediante autorização do órgão ambiental estadual competente, a supressão do pequizeiro será admitida.
} 
estes motivos esta espécie é uma das únicas dentre as nativas que começa a surgir no rol das indicadas para arborizar pastagens (MELOTTO et al., 2012; LORENZI, 2002). Pequi e baru também são capazes de melhorar a umidade e fertilidade do solo em pastagens e o valor nutricional do capim (OLIVEIRA, 1999).

\section{- As famílias mais importantes}

Muitos levantamentos em áreas preservadas de Cerrado têm diagnosticado a família Leguminoseae como mais rica em espécies (MENDONÇA et al. 2008; SILVA et al. 2002; WEISER \& GODOY 2001). Esta família possui $24 \%$ das espécies da flora vascular do cerrado, sua relevância se estende para as diferentes fitofisionomias e estratos (MENDONÇA et al., 2008). Sua predominância nas pastagens estudadas é, portanto influenciada por uma característica natural da vegetação e pode estar sendo ressaltada por uma escolha dos pecuaristas em consequência do provável beneficiamento do capim sob sua área de influencia, devido a característica de algumas espécies em fixar de nitrogênio ao solo (MARTINS, 1993). Porém este argumento não foi diretamente citado pelos pecuaristas nas entrevistas, embora muitos tenham falado que as árvores, de forma geral, adubam o solo e beneficiam o capim.

\section{Distribuição diamétrica e manejo da regeneração}

Em relação à distribuição diamétrica muitos estudos ecológicos indicam que existe uma tendência em florestas tropicais e no Cerrado da distribuição em curva exponencial negativa, embora muitas espécies tenham uma distribuição irregular (QUEIROZ, 2004; ANDRADE et al., 2002). As árvores das pastagens estudadas seguiram este padrão de distribuição. Houve uma queda abrupta entre as duas primeiras classes, o que deve estar relacionado ao frequente manejo denominado "limpeza" da pastagem, em que além de herbáceas e arbustos, as árvores de menores diâmetros são eliminadas para propiciar mais luz para as gramíneas ${ }^{19}$.

Em estudo na Colômbia encontrou-se uma realidade similar, ou seja, uma abundante regeneração natural com densidades altas de plântulas e mudas (com alturas de 0,1 a 1,5 metros, média de 380 ind./ha) (CAMARGO, 2005). Porém, as plantas jovens (de 1,5 m a $5 \mathrm{~cm}$ de DAP) sofrem uma abrupta queda de densidade, com menos de $4 \mathrm{ind} / \mathrm{ha}$, justamente devido a ação dos pecuaristas de "limpar" o pasto. Já as plantas adultas

\footnotetext{
${ }^{19}$ Esta questão será melhor discutida quando da análise das respostas dos pecuaristas sobre a forma de manejar suas pastagens.
} 
(DAP > $5 \mathrm{~cm}$ ) apresentaram densidade média maior que as jovens (41,8 ind./ha), pois são as que possuem utilidades para os pecuaristas e foram deixadas nos pastos. Esta quantidade e distribuição de árvores nas pastagens indicam um potencial de desenvolver SSPs por meio do manejo da regeneração natural, porém a tendência de eliminar árvores jovens inviabiliza o processo. Embora no Cerrado tenha havido uma abrupta diminuição de indivíduos, devido ao manejo de limpeza das pastagens, ainda assim há sempre um número superior de indivíduos mais jovens do que mais velhos. Em termos práticos, isso representa a possibilidade de manutenção e inclusive o enriquecimento das árvores nas pastagens, já que 40,7\% mencionaram que gostariam de ter uma quantidade maior de árvores nos pastos do que possuem. Porém, isso depende das decisões dos pecuaristas ao manejarem estas áreas produtivas. Nas entrevistas 93\% confirmaram que selecionam, parte das árvores regenerantes para permanecer na pastagem de acordo com uma série de critérios (Tabela 3). $\mathrm{O}$ argumento mais mencionado foi o de repor as árvores que vão morrendo.

A alta capacidade de reprodução vegetativa das árvores do cerrado, especialmente a rebrota de raiz (RIZZINI, 1979; VIEIRA et al. 2006; FERREIRA et al., 2015; MEDEIROS e MIRANDA, 2008) representa uma vantagem para a arborização das pastagens no Bioma. Elas possibilitam aos pecuaristas mais oportunidades e opções ao planejar o futuro da arborização de suas pastagens a um baixo custo. Esse tipo de regeneração é mais vigorosa e apresenta maior crescimento do que as regenerantes de sementes e mudas plantadas (CARDOSO, 2012; KAMMESHEIDT, 1999). Isso é vantajoso, especialmente para sobreviver aos possíveis danos causados pelo gado. A característica das árvores de regenerarem em locais perturbados, incluindo as pastagens, demonstra ser duradoura, pois pastagens de 25 anos, localizadas no Cerrado, em ambiente de mata seca, apresentaram alta regeneração, com elevada riqueza (VIEIRA et al., 2006), inclusive, muitas das espécies encontradas em tal trabalho são as mesmas das pastagens aqui estudadas.

Um desafio a ser superado é a visão dominante, inclusive entre profissionais das ciências agrárias, de que estas rebrotas devem ser totalmente combatidas para permitir maior produtividade do sistema. Usualmente os regenerantes arbóreas são considerados plantas daninhas (LORENZI; POTT E POTT, 2006), porém este julgamento não é acompanhado de uma análise mais completa das vantagens e desvantagens que elas podem trazer dependendo das quantidades e espécies presentes e formas de manejá-las. 
A maioria (88\%) dos pecuaristas realizam o manejo das rebrotas e a metodologia adotada variou entre os entrevistados em relação a periodicidade adequada, época do ano e equipamentos utilizados, o que mostra uma diversidade de formas de ser feito. Portanto, para que esta característica da vegetação do cerrado possa ser encarada como vantajosa é preciso aprofundar estudos sobre o assunto e divulgá-los.

Outros sistemas produtivos que envolvem pastagens com árvores nativas em diferentes países relatam que a baixa quantidade de regenerantes constitui-se uma das principais preocupações acerca do tema. Tal regeneração é prejudicada pela combinação do uso de herbicidas, gramíneas de alta produtividade e o impacto dos animais (pisoteio e forrageamento) (VILLANUEVA et al., 2003; MIMENZA et al., 2011). Um desafio chave neste sistema de árvores nativas nas pastagens é manter o equilíbrio entre o recrutamento e mortalidade de árvores (MANNING, 2006). A exclusão temporária do gado dos piquetes, bem como a conscientização e capacitação dos pecuaristas quanto às práticas de manejo que permitam a regeneração natural e o estabelecimento de indivíduos jovens são urgentes para a sustentabilidade dos SSPs com esta realidade (MIMENZA et al., 2011; HARVEY et al., 2011)

Em relação à mortalidade das árvores nas pastagens, a presente pesquisa encontrou $1,9 \%$ dos indivíduos nesta categoria. Tal percentual está abaixo do encontrado em outros estudos de fitossociologia em áreas preservadas de cerrado sensu strictu que obtiveram $7 \%$ e $5,6 \%$ de indivíduos mortos, a maior parte deles nas primeiras classes diamétricas (ANDRADE et al., 2002; FELFILI \& SILVA JÚNIOR, 2001). Isso pode ser devido a retirada destas árvores para aproveitamento da madeira pelos pecuaristas, já que $60 \%$ deles citaram, ao longo das entrevistas, que priorizam usar madeira de árvores que morreram naturalmente.

\section{Motivações para ter árvores na pastagem}

Diversos trabalhos sobre motivações dos pecuaristas para ter árvores na pastagem no Panamá e Costa Rica tiveram seus argumentos principais com similaridade ao deste estudo como o fornecimento de sombra aos animais (LOVE E SPANER, 2005; HARVEY e HABER, 1999) a reserva de madeira para uso futuro (HARVEY e HABER, 1999, GAREN et al., (2011). O favorecimento do capim foi citado com percentual inferior às demais justificativas (HARVEY e HABER, 1999; GAREN et al., 2011), ou não foi mencionado (LOVE e SPANER, 2005), o que contrasta com os resultados encontrados na presente pesquisa. Isso talvez se deva a falta de consenso 
sobre os efeitos positivos das árvores sobre as gramíneas, pois variam conforme a precipitação da região, sendo mais evidentes em locais com severa restrição hídrica (BLASER et al., 2013). No presente estudo, a importância das árvores para usos madeireiros pode estar sub-estimada devido a insegurança dos pecuaristas de comentar sobre este uso, observado durante as entrevistas, já que o corte de algumas espécies é proibido e outras vezes dependem de autorização prévia, um procedimento burocrático que muitas vezes os pecuaristas não realizam. No entanto, durante a conversa sobre a utilidade de cada espécies estudada (Capítulo 3), os entrevistados demostraram conhecimento detalhado sobre o uso madeireiro das espécies nativas, principalmente em relação as madeiras com maior presteza na propriedade, com destaque para as de melhor qualidade para cercamento.

Diversos trabalhos na América Central abordam a importância das árvores nas pastagem para funcionar como cercas vivas (GUINDON, 1988; MIMENZA, 2011; CASTILHO, 2013,), quebra ventos (HARVEY e HABER, 1999; HARVEY, 2000; MURGEITIO, 2011), e forragem (GAREN et al., 2011; MIMENZA 2007), porém, estas motivações foram pouco frequentes entre os pecuaristas entrevistados. Ao analisar trabalhos que verificaram as motivações dos pecuaristas em possuir árvores em seus pastos, percebese que a importância (frequência) de cada justificativa varia bastante, isto possivelmente está relacionado às peculiaridades locais, por exemplo, condições edafo-climáticas e questões culturais (GAREN et al., 2011).

A maior parte das motivações (91\%) dos pecuaristas entrevistados para ter árvores nas pastagens está relacionada à questão produtiva, seja por gerar benefício ao capim, ao gado, ao solo, ou obter produtos das árvores, portanto, caracterizam-se como questões econômicas. Os benefícios ambientais das árvores nas pastagens parecem secundários aos pecuaristas do Cerrado, quando comparados à questão econômica. Porém, em um outro estudo realizado também no Cerrado sobre as motivações dos pecuaristas em plantar árvores, a questão ambiental foi tão citada quanto a questão econômica (DOURADO, et al., 2013). Isso pode estar relacionado ao fato que plantar árvores exige um esforço (físico e financeiro) maior que apenas mantê-las, como no caso dos SSP aqui estudados, portanto, os que plantam possivelmente estão mais motivados e conscientes dos seus benefícios, não só econômicos, mas também ambientais. 


\section{Dificuldades e desafios}

Em relação aos principais desafios e dificuldades deste tipo de sistema percebe-se que as três justificativas mais citadas estão bastante inter-relacionadas e tratam sobre a falta de maquinário apropriado, problema que afeta não apenas este tipo de sistema, mas de forma geral, cultivos mais complexos e biodiversos, assim como realidades da agricultura de pequena escala (ALBIERO et al., 2015). É importante que esta discussão ganhe força e visibilidade para pressionar a criação/adaptação e disponibilização de maquinário adequado a este tipo de sistema, de modo a melhorar o manejo do solo, a eficiência do trabalho e diminuir o tempo e esforço manual dos trabalhadores. Outra ação importante relaciona-se a capacitação e sensibilização dos tratoristas sobre seu papel para sustentabilidade das pastagens com árvores.

\section{Manejo e conhecimento envolvido}

Os pecuaristas selecionam as espécies arbóreas durante a formação das pastagens arborizadas e posteriormente, durante sua "limpeza", ao escolher as regenerantes que devem ser protegidas, portanto, realizam manejo da biodiversidade ao favorecer as espécies que julgam mais úteis, baseados em diferentes critérios (Tabelas 2 e 3). Mesmo diante desta seleção, ainda assim, a riqueza de árvores é elevada, o que favorece a conservação da biodiversidade in loco e na escala da paisagem, enfatizando o papel destas pastagens como corredores biológicos (BHAGWAT et al., 2008). Outro indício da influencia dos pecuaristas na atual composição de espécies arbóreas nas pastagens é o fato das árvores regenerantes com alta densidade encontradas no presente estudo não aparecem de forma significativa na composição de espécies maiores do que $5 \mathrm{~cm}$ de DAB, embora este fato possa ser influenciado também pela ação do gado.

O favorecimento de espécies multi-propósito, principalmente as madeireiras e frutíferas também é frequente por pecuaristas de outros países (GARENA et al., 2011; HARVEY et al. 2011; SHERREN, 2012). Além de gerar produtos, as árvores são escolhidas baseado na interação que promove com o gado e o capim, como por exemplo, a escolha de espécies altas e de grande copa. Grande parte dos pecuaristas mostrou conhecimento das árvores em relação aos benefícios ou prejuízos que causam ao capim e ao gado, seja ao mencionar as características ou exemplificar com as espécies. Várias características citadas estão de acordo com a literatura, como o benefício ao capim por copas altas e ralas, e a interferência negativa de copas baixas e densas (CARVALHO, 2001; PORFIRIO-DA-SILVA, 2015). Este é um conhecimento técnico importante para a 
produtividade e aprimoramento do sistema, mas ainda pouco disponível na literatura, sobretudo com abordagem especifica das árvores do Cerrado. São necessárias pesquisas para confirmar, além de compreender em que circunstâncias ocorrem tais interações, ou refutar certas informações citadas.

As espécies mencionadas como as mais procuradas pelo gado e também as que mais beneficiam o capim são as que apresentaram maior índice de valor de importância no levantamento realizado (Caryocar brasiliense, Pterodon sp e Dipteryx alata). Não é possível determinar se estas espécies foram as mais citadas por influencia da maior quantidade de indivíduos, por serem maiores, por estarem presentes em mais propriedades, ou por outro lado, se justamente por trazerem mais benefícios ao sistema são priorizadas no manejo. Provavelmente trata-se de interação em ambos sentidos.

A menção à aroeira, por prejudicar o capim, de acordo com alto percentual dos entrevistados, merece destaque, mesmo por que ela apresenta copa rala e alta, consideradas características vantajosas (vide Capítulo 3). Apenas uma referencia superficial sobre o assunto foi encontrada, o experimento foi realizado com extrato de folhas e ramos de aroeira em contato com sementes de braquiária, e apresentou efeito negativo na germinação e comprimento da raiz. Portanto, há indícios de alelopatia desta espécie com a braquiária (BANADIO, 2014). O assunto necessita ser aprofundado, visto que existe sistema silvipastoril com predomínio desta espécie onde não há relatos deste tipo de problema (VIANA et al., 2002).

A partir das conversas sobre a formação e o manejo das pastagens, com foco no elemento arbóreo, e suas inter-relações com os animais, as gramíneas e com os próprios pecuaristas, percebeu-se que a maior parte dos entrevistados possui conhecimento detalhado sobre o assunto. Estes aprendizados, segundo $79 \%$ dos pecuaristas, são provenientes da experimentação e observação cotidiana, do aprender por meio de tentativa e erro, do olhar atento às respostas do próprio sistema, que provavelmente, só foi possível desenvolver-se na ausência de uma assistência técnica convencional, que parece estar ausente nestes locais. Porém, um tipo de assistência técnica que respeite e valorize as preferencias destes criadores de gado, que gostam de ter árvores nativas na pastagem pode ser muito útil ao aprimoramento deste sistema. 


\section{CONSIDERAÇÕES FINAIS}

Existem diversos sistemas silvipastoris com árvores nativas dispersas nos pastos localizados no Bioma Cerrado que possuem diversas configurações, com baixa até alta densidade e riqueza de espécies. Há o predomínio de árvores multipropósito, especialmente frutíferas e madeireiras. Neste estudo houve destaque para pequi, baru, sucupira branca e preta que são espécies de madeira nobre, sendo que as duas primeiras são frutíferas, e todas quatro apresentam copa larga com farto sombreamento.

Os pecuaristas reconhecem diversos benefícios em manter árvores nativas do Cerrado na pastagem principalmente relacionadas à questão produtiva seja por beneficiar o solo, o capim, o gado ou obter produtos destas árvores. Boa parte dos pecuaristas disseram não ver problemas em adotar este sistema, porém questões relacionadas à dificuldade de mecanização para formar e manejar SSPs foram mencionadas. O encontro de soluções para este problema parece fácil caso haja interesse dos fabricantes de maquinários agrícolas já existentes em adaptar os estes equipamentos diante de tal demanda. A formação e o manejo das pastagens ocorre simultaneamente ao manejo da biodiversidade nativa, assim os pecuaristas configuram-se como importantes gestores deste patrimônio. Eles demonstram conhecimento das utilidades das árvores e acerca da sua influencia direta no sistema (gado, capim, solo) de acordo com as diferentes características que apresenta.

Um aspecto diferencial dentre os sistemas silvipastoris com árvores nativas aqui estudados e em outras partes do mundo é a capacidade das pastagens do Cerrado possibilitarem a regeneração de grande quantidade de indivíduos e riqueza de espécies arbóreas, muitas vezes, por longos períodos. A baixa quantidade de regenerantes é uma das maiores preocupações sobre a continuidade destes sistemas em outras regiões, já aqui pode ser encarado como uma vantagem, pois além de permitir perpetuação das árvores no sistema, gera inúmeras possibilidades de modificação e aperfeiçoamento do SSP. 


\section{REFERÊNCIAS BIBLIOGRÁFICAS}

AFONSO, S.R., ÂNGELO, H., Mercado dos produtos florestais não-madeireiros do Cerrado brasileiro. Ciência Florestal, v. 19, p. 315-326, 2009.

ALBIERO, D. et al. (org.) Tecnologias agroecológicas para o Semiárido. Fortaleza: Universidade Federal do Cerará, 2015. 216 p

ANDRADE, L. A.. Z; FELFILI, J. M.; VIOLATTI, L Fitossociologia de uma área de cerrado denso na RECOR-IBGE, Brasília-DF. Acta bot. bras., v. 16, n. 2, p. 225-240, 2002.

ALMEIDA, S. P. et al. Cerrado: espécies vegetais úteis. Planaltina: EMBRAPACPAC, 1998, 464p.

ALMEIDA, R. G.; et al. Brazilian agroforestry systems for cattle and sheep. Forrajes Tropicales., v. 1, p. 175-183, 2013.

BARDIN, Laurence. Análise de Conteúdo.Tradução Luís Antero Reto, Augusto Pinheiro. São Paulo: Edições 70, 2011.

BAUER, M. W.; GASKELL, G. Pesquisa qualitativa com texto, imagem e som, um manual prático. Petrópolis: Vozes. 7 ed. 2008.

BHAGWAT, S. A. et al. Agroforestry: a refuge for tropical biodiversity? Trends in Ecology \& Evolution, v. 23, p. 261-267, 2008

BORGES, H. B. N. Biologia reprodutiva e conservação do estrato lenhoso numa comunidade do cerrado. Tese de Doutorado. PPG Biologia Vegetal, Campinas: SP, 2000.

BRASIL, MINISTÉRIO DO MEIO AMBIENTE. Mapeamento do uso e cobertura da terra do Cerrado: Projeto TERRACLASS Cerrado 2013. Brasília, 2015a, 69 p.

BRASIL, MMA, Monitoramento do desmatamento nos biomas brasileiros por satélite: Cerrado 2010-2011 Brasília, 2015b, 16 p.

BRÁZ, S. P.; NASCIMENTO JR., D. N.; CANTARUTTI, R. B. Caracterização da distribuição espacial das fezes por bovinos em uma pastagem de Brachiaria decumbens. Revista Brasileira de Zootecnia. Viçosa, v. 32, n. 4, p.787-794, 2003.

BRAZIL FLORA GROUP. Growing knowledge: an overview of Seed Plant diversity in Brazil. Rodriguésia, v. 66, n. 4, p 1085-1113, 2015. 
BRANNSTROM, C., et al. Land change in the Brazilian Savanna (Cerrado), 19862002: comparative analysis and implications for land-use policy. Land Use Policy, v. 25, n.4, p. 579-595, 2008

BRIDGEWATER, S.; RATTER, J. A.; RIBEIRO, J. F. Biogeographic patterns. Betadiversity and dominance in the carrado biome of Brazil. Biodiversity and Conservation, v. 13, p. 2295-2318, 2004.

CAMARGO, A. P. Clima do Cerrado. In: Simposio sobre o cerrado. São Paulo: SP. Editora da Universidade de São Paulo: 1856, 1963. p. 93-115.

CAMARGO, J. C. et al. Silvopastoral systems with isolated timber trees within pastures in the Coffe region of Colombia. Livestock Research for Rural Development. v. 17, n. 5, 2005.

CARRAZZA, L. R,; ÁVILA, J. C. C. Manual tecnológico de aproveitamento integral do fruto do Baru (Dipteryx alata) Brasília: ISPN, 2010. 56p.

CARVAlHO, M. M.; XAVIER, D. F.; ALVIM, M. J. Características de algumas leguminosas arbóreas adequadas para a associação com pastagens. Juiz de Fora: Embrapa Gado de Leite, 2001. 24 p. (Circular Técnica, 64).

CARVAlHO, F. M. V; DE MARCO JÚNIOR, P.; FERREIRA, L. G. et al. The Cerrado into-pieces: habitat fragmentation as a function of landscape use in the savannas of central Brazil. Biological Conservation, v. 142, p. 1392-1403, 2009.

CASTRO, C. R. T; PACIULlO D. S. C. Boas práticas para a implantação de sistemas silvipastoris. Juiz de Fora: Embrapa Gado de Leite. 2006. (Comunicado Técnico, 50).

CNUC/MMA. Unidades de Conservaçao por Bioma. In: Cadastro Nacional de Unidades de Conservação/ Ministério do Meio Ambiente. 2016. Disponível em: <http://www.mma.gov.br/images/arquivo/80112/CNUC_PorBiomaFev16.pdf> Acesso em julho de 2016.

CORDEIRO, L. Caraterização de nódulos em leguminosas de Cerrado. In:

Reuniao Latino-Americano sobre rhizobium. 12. ed. Campinas.: Instituto Agronômico., 1986. p. 191-197.

CASTILLO, J. M. D. Provisión de los servicios ecosistémicos carbono y madera en pasturas activas del Corredor Biológico Volcánica Central Talamanca, Costa Rica. 
2013. 61 f.. Dissestação (Magister Scientiae en Agroforestería Tropical) Centro Agronómico Tropical e Investigación y Enseñanza Escuela de Posgrado. Turrialba, Costa Rica, 2013

DOURADO, B. F.; VIEIRA,. D. L. M.; MOREIRA, N. Porque eu, agricultor, planto árvore no Cerrado. Revista Cadernos de Agroecologia, v. 8, n. 2, p.1- 6, 2013.

EITEN, G. The cerrado vegetation of Brazil. The Botanical Review, v. 2, n. 38, p. 201$341,1972$.

EITEN, G. Vegetação do Cerrado. In: NOVAES PINTO, M., Cerrado: caracterização, ocupação e perspectivas. Brasília: Universidade de Brasília.: [s.n.], 1994.

FARIA, S. M. et al. New nodulating legume trees from south-east Brazil. New Phytologist, v. 98, p. 317-328, 1984.

FARIA, S. M. D. et al. Nodulation of legume trees from south east Brazil. Plant and soil., v. 99, p. 347-356, 1987.

FARIA, S. M. D.; LEWIS, G. P.; , J. M. Ocurrence of nodulation in Leguminosae. New Phytologist, v. 111, p. 607-619, 1989.

FEARNSIDE, P. M. Soybean cultivation as a threat to the environment in Brazil. Environmental Conservation, v. 28, p. 23-38, 2001.

FELFILI, J. M.; SILVA JR., M. C. Biogeografia do bioma Cerrado: Estudo fitofisionômico da Chapada do Espigão Mestre do São Francisco. [S.1.]: [s.n.], 2001.

FERRI, M. G.; COUTINHO, L. M. Contribuição ao conhecimento da ecologia do cerrado. Estudo comparativo da economia d'água de sua vegetação em Emas(SP), Campo Grande(MT) e Goiânia(GO). Boletim da Faculdade de Filosofia, Ciência e Letras., São Paulo: Universidade de São Paulo., 12, 1958. 103-150.

FERREIRA, L. C. B. Respostas fisiológicas e comportamentais de bovinos submetidos a diferentes ofertas de sombra, 2010. 89 f. Dissertação (mestrado). Universidade Federal de Santa Catarina, Florianópolis , 2010

FERREIRA, M. C; WALTER, B. M. T.; VIEIRA, D. L. M. Topsoil translocation for Brazilian savanna restoration: propagation of herbs, shrubs, and trees. Restoration Ecology, v. 23, n. 6, p. 723-728, nov. 2015

FORZZA, R. C.; et al. New Brazilian january floristic list highlights conservation challenges. BioScience, v. 62, n. 1, p. 39-45, Jan. 2012. 
FRANCO, A. C. Ecophysiology of wood plants. In: OLIVEIRA, P. S.; MARQUIS, R. J. The Cerrados of Brazil: ecology and natural history of a neotropical savanna. [S.1.]: Columbia University Press., 2002. p. 178-198.

FRANÇOSO, R. D. Padrões biogeográficos e composição das comunidades arbóreas do Cerrado brasileiro. 2014. 158 f. Tese (Doutorado em Ecologia) - Instituto de Ciências Biológicas, Universidade de Brasília, Brasília, 2014.

FURLEY, P.; RATTER, J. A. Soil resources and plant communities of the central brazilian cerrado and their development. Journal of Biogeography., v. 15, n. 1, p. 97 $108,1988$.

GARENA, E. J.; et al. The tree planting and protecting culture of cattle ranchers and small-scale agriculturalists in rural Panama: Opportunities for reforestation and land restoration. Forest Ecology and Management., v. 261, p. 1684-1695, 2011.

GIL, A. C. Como Elaborar Projetos de Pesquisa. São Paulo: Atlas, 2002.

GUEVARA, S.; LABORDE, J.; SANCHEZ, G. Are isolated trees in pastures a fragmentes canopy? Selbyana., v. 19, n. 1, p. 34-43, 1998.

HARIDASAN, M. Nutrição mineral das plantas ativas do Cerrado. Revista Brasileira de Fisiologia Vegetal, v. 12, n. 1, p. 54-64, 2000.

HARTEL, T.; PLIENINGER, T.; VARGA, A., Wood-pastures In: HYPERLINK "http://www.worldcat.org/search?q=au\%3AKirby\%2C+K.+J.\%2C\&qt=hot_author" Io "Buscar por mais deste autor" KIRBY, K. J.; HYPERLINK "http://www.worldcat.org/search?q=au\%3AWatkins\%2C+C.\%2C\&qt=hot_author" lo "Buscar por mais deste autor" WATKINS, C. Europe's changing woods and forests : from wildwood to cultural landscape. Boston, MA: CABI International, 2015. p.6176

GAREN, E. J.; et al. The tree planting and protecting culture of cattle ranchers and small-scale agriculturalists in rural Panama: Opportunities for reforestation and land restoration. Forest Ecology and Management., v. 261, p. 1684-1695, 2011.

GRANDE, D. et al. Importance and function of scattered trees in pastures in the Sierra Region of Tabasco, Mexico. Research Journal of Biological Sciences, v. 5, n.1, p.75 87,2010 
HARVEY, C. A.; et al. Conservation value of dispersed tree cover threatened by pasture management. Forest Ecology and Management, v. 261, p. 1664-1674, 2011.

HARVEY, C. A.; HABER, W. A. Remnant trees and the conservation of biodiversity in Costa Rican pastures. Agroforestry Systems, v. 44, p. 37-68, 1999.

HARVEY, C. A. The colonization of agricultural windbreaks by forest trees in Costa Rica: implications for forest regeneration. PhD Dissertation. Department of Ecology and Systematics, Cornell University, 1999

HARVEY, C. A.; IBRAHIM, M. Diseño y manejo de la cobertura arbórea en fincas ganaderas para mejorar las funciones productivas y brindar servicios ecológicos. Agrofloresteria en las Americas, v. 10, n. 39-40, p. 4-6, 2003.

HARVEY, C. A., Conservation value of dispersed tree cover threatened by pasture management. Forest Ecology and Management, v. 261, p. 1664 -1674, 2011

IBGE. Censo Demográfico 2010. Instituto Brasileiro de Geografía e Estatística. [S.1.]. 2010.

KLINK, C. A.; MOREIRA, A. G. Past and current human occupation, and land use. In: OLIVEIRA, P. S., MARQUIS, R. J. (Eds.), The Cerrados of Brazil: Ecology and Natural History of a Neaotropical Savanna. Columbia Univeristy Press, New York, 2002, pp. 69-88.

KLINK, C. A.; MACHADO, R. B. Conservation of the Brazilian Cerrado. Conservation Biology. v. 19, p. 707-713, 2005

LOVE, B.; SPANER, D. A survey of small-scale farmers using trees in pastures in Herrera Province, Panama, Journal of Sustainable Forestry, v. 20, p. 37-65, 2005.

MAGALHÃES, L. M. S.; FERNANDES, N. P. Plantios esperimentais de leguminosas florestais na região de Manaus. Pesquisa Agropecuária Brasileira., v. 19, p. 75-79, 1984.

MANNING, A. D.; FISCHER, J.; LINDENMAYER, D. B. Scattered trees are keystone structures - Implications for conservation. Biological Conservation, v. 132, p. 311-321, 2006.

MARTINELLI, L. A.; FILOSO, S. Expansion of sugarcane ethanol production in Brazil: Environmental and social challenges. Ecol. Appl, v. 18, p. 885-898, 2008. 
MARTINS, F. R. Estrutura de uma floresta mesófila. 2 ${ }^{\text {a }}$ Edição. Editora da Unicamp, Campinas, 1993.

MEDEIROS, M. B.; MIRANDA, H. S. Post-fire resprouting and mortality in Cerrado woody plant species over a three-year period. Edinburgh Journal of Botany, v. 65, p. 53-68, 2008.

MENDONÇA, R. C.; et al. Flora vascular do cerrado. In: SANO, M.; ALMEIDA, S. P. Cerrado ambiente e flora. Planaltina: EMBRAPA-CPAC: [s.n.], 1998. p. 287-556.

MIMENZA, H. E. Dispersed trees in pasturelands of cattle farms in a tropical dry ecosystem. Tropical and subtropical agroecosystems, v. 14 p. 933-941, 2011.

MORTON,s D. C.; DEFRIES R. S.; SHIMABUKURO, Y. E. Quantifying cropland expansion in cerrado and transition forest ecosystems with Modis satellite image time series. In: Proc. Symp. on Cerrado Land-Use and Conservation: Assessing TradeOffs Between Human and Ecological Needs, Brasília, Brazil, Society for Conservation Biology. 2005.

MÜELLER-DOMBOIS D.; ELLENBERG $\mathrm{H}$. Aims and methods of vegetation ecology. New York: Wiley and sons, 1974.

MUÑOZ, D. et al. Conocimiento local de la cobertura arbórea em sistemas de producción ganadera en dos localidades de Costa Rica. Agrofloresteria en las Americas., v. 10, n. 39-40, p. 61-68, 2003.

MURGUEITIO, R. E. et al. Native trees and shrubs for the productive rehabilitation of cattle ranching lands. Forest Ecology and Management. v. 261, p.1654-1663, 2011

MYERS, N. et al. Biodiversity hotsposts for conservation priorities. Nature., v. 403, n. 6772, p. 853-858, 2000.

OLIVEIRA, M. E. Influência de árvores das especies nativas dipteryx alata Vog. e caryocar brasiliense Camb. no sistema solo-planta em pastagem de brachiaria decumbens Stapf no cerrado. 1999. 104 p. Tese (Doutorado em Ecologia) Faculdade de Ciências Biológicas, Universidade de Brasília, Brasília, 1999.

OLIVEIRA-FILHO, A. T. Estudos ecológicos da vegetação como subsídios para programas de revegetação com espécies nativas: uma proposta metodológica. Revista Cerne, Lavras, v.1, n.1, p.64-72, jan./dez. 1994. 
OLIVEIRA-FILHO, A. T.; RATTER, J. A. Vegetation physiognomies and wood flora of the Cerrado biome. In: OLIVEIRA, O. S.; MARQUIS, R. J. The cerrados of Brazil: ecology and natural history of a neotropical savanna. New York: Columbia University Press: [s.n.], 2002. p. 91-120.

PERFECTO I.; VANDERMEER J. The agroecological matrix as alternative to the landsparing/agriculture intensification model. Proceedings of the National Academy of Sciences v. 107, p 5786-5791, 2010.

PORFÍRIO-DA-SILVA, V. Ideótipo de espécie arbórea para Sistemas de Integração Lavoura-Pecuária-Floresta. In: LAURA, V. A., ALVES, F. V., ALMEIDA, R. G. Sistemas agroflorestais: a agropecuária sustentável, Brasília : Embrapa, 2015. 208 p RANZANI, G. Solos do cerrado. In: Simposio sobre o cerrado. São Paulo: SP: [s.n.], 1963. p. 423.

RATTER, J. A.; BRIDGEWATER, S.; RIBEIRO, J. F. Analysis of the floristic composition of the brazilian cerrado vegetation III: Comparison of the woody vegetation of 376 areas. Edinburgh journal of botany., v. 60, n. 1, p. 57-109, 2003.

RATTER, J. A.; RIBEIRO, J. F.; BRIDGEWATER, S. The brazilian cerrado vegetation and threats to its biodiversity. Annals of Botany, v. 80, p. 223-230, 1997.

REID, N.; LANDSBERG, J. Tree decline in agricultural landscapes: what we stand to lose In: REID, N.; LANDSBERG, J. Temperate eucalypt woodlands in Australia: Norton: Biology, Conservation, Management and Restoration Surrey Beatty \& Sons, Chipping, 2000

REY, F. G. La investigación cualitativa en Psicología: rumbos y desafios. São Paulo: Educ, 1999.

RIBEIRO, J. F.; WALTER, B. M. T. As prinipais fitofisionomias do bioma Cerrado. In: SANO, S. M.; ALMEIRA, S. P.; RIBEIRO, J. F. Cerrado: ecologia e flora. Brasília, DF: EMBRAPA: [s.n.], 2008. p. 151-212.

RUIZ, J.; FANDIÑO, M. C.; CHAZDON, R. L. Vegetation structure, composition, and species richness across a 56-year chronosequence of dry tropical forest on Providencia Island, Colombia. Biotropica, v. 37, n. 4, p. 520-530, 2005.

SILVA-JUNIOR, M. C. 100 Árvores do Cerrado sentido restrito: guia de campo. Brasília: Rede de Sementes do Cerrado, 2012, 304p. 
SOLÓRZANI, N. et al. Inventario de árboles en potreros en fincas del municipio Guanarito, estado Portuguesa. Revista Unellez de Ciencia y Tecnología, v. 24, p. 8-16, 2006.

SANO, E. E. et al. Mapeamento semi detalhado do uso da terra do bioma cerrado. Pesquisa Agropecuária Brasileira, v. 43, n. 1, p. 153-156, 2008.

SCHIRMER, J.; DOVERS, S.; CLAYTON, H. Informing conservation policy design through an examination of landholder preferences: A case study of scattered tree conservation in Australia. Biological Conservation, v. 153, p. 51-63, 2012.

SPRENT, J. I.; CORDEIRO, L. Nodulated legume trees in the cerrado: Taxonomic distribution, infection process and nodule morphology. Ciência e cultura., v. 44, n. 53, p. 336-338, 1992.

SZYMANSKY, H. (Coord.); ALMEIDA, L. R.; BRANDINI, R. C. R. A Entrevista na pesquisa em Educação: a prática reflexiva. Brasília: Liber Livro Editora, 2004. 87p.

TOGASHI, M.; SGARBIERI, V. C. Caracterização química parcial do fruto do baru. Ciência e Tecnologia de Alimentos, Campinas, v. 14, n. 1, p. 85-95, 1994.

VILLACIS, J. et al. Relaciones entre la cobertura arbórea y el nivel de intensificación de las fincas ganaderas en Rio Frio, Costa Rica. Agroforestería en las Américas. v. 10, n. $39-40$, p. $17-23,2003$

VILLANUEVA, C.; et al. Decisiones claves que influyen sobre la cobertura arbórea en fincas ganaderas de cañas, Costa Rica. Agrofloresteria en las Americas., v. 10, n. 3940, p. 68-77, 2003.

WEISER, V. L.; GODOY, S. A. P. Florística em um hectare de cerrado stricto sensu na ARIE - Cerrado Pé-de-Gigante, Santa Rita Do Passa Quatro, SP. Acta Bot. Bras, v. 15 , n. 2, p. 201-212, 2001 


\section{CAPÍTULO 3 - POTENCIAL DE ESPÉCIES ARBÓREAS DO CERRADO PARA COMPOREM SISTEMAS SILVIPASTORIS}

\section{INTRODUÇÃO}

Por um longo período a pecuária vem sendo considerada antítese de conservação da biodiversidade e manutenção dos serviços ambientais (PERFECTO e VANDERMEER, 2010). Entretanto, trabalhos recentes tem mostrado que certos tipos de silvipastoris, são capazes de contribuir com a conservação da biodiversidade in loco (HARVEY E HABER, 1999; LUNT, 2005; HARVEY et al. 2011; MCADAM et al., 2007) e na escala da paisagem (GIBBONS e BOAK, 2002; GALINDO et al., 2000; FISCHER e LINDENMAYER, 2002; HARVEY et al., 2006; MEDINA et al., 2007;) contribuindo com o paradigma emergente de conciliação entre produção e conservação ambiental (MURGUEITIO et al, 2011; TOLEDO Y BARRERA-BASSOLS, 2010).

Entretanto estudos sobre árvores nativas para compor SSP ainda são poucos e possuem caráter exploratório; normalmente são diagnósticos de levantamento das espécies presentes em campo ou entrevistas com pecuaristas (LOVE e SPANER, 2005; FRANKE, 1999; SANTOS e MITJA, 2011; SOUTO et al., 2003). Alguns estudos avaliam a sobrevivência e o crescimento inicial de espécies plantadas para formar SSP (MELO e ZOBY, 2004; MELOTTO et al., 2009, POTT e POTT, 2003), mas poucos avaliam e descrevem um conjunto de características das espécies arbóreas que influenciam os SSP conforme Andrade, 2012; Pott e Pott, 2003.

As dúvidas mais marcantes dos pecuaristas interessados em ter o consórcio de árvores com pastagem são relacionadas à escolha das espécies arbóreas e sua densidade ideal (ANDRADE et al., 2012). A escolha das espécies deve considerar os objetivos do produtor e as características desejáveis das árvores. A arquitetura da copa e a densidade de folhagem podem ser utilizadas como bons indicadores da incidência de luz sob as árvores (KABAKOFF e CHAZDON, 1996) e irá influenciar o microclima e, provavelmente, a produtividade da pastagem e dos animais. Espécies boas para arborizar pastagens devem possuir adaptação ao solo e ao clima da região, ter produtos que possam ser comercializados, melhorar o microclima da área e, em caso de plantios, devem possuir facilidade de estabelecimento e crescimento rápido (SILVA et al., 2010; CARVALHO, 1998). Outras características desejáveis são fuste alto, copas pouco 
densas, preferencialmente perenifólia, capacidade de fixação de nitrogênio e associação com micorrizas, ausência de efeitos alelopáticos sobre a forragem e efeitos tóxicos aos animais, não possuir caráter invasor, ter resistência ao vento e ao fogo acidental, capacidade de produzir alimento palatável ao gado, gerar produtos madeireiros e não madeireiros (ANDRADE et al, 2012; CARVALHO, 1998; 2001; PORFIRIO-DASILVA, 2015). O potencial forrageiro das árvores é útil aos SSPs, especialmente em regiões onde a sazonalidade das plantas forrageiras é marcante (KU, 2005; MIMENZA, 2007; MAIA, 2004).

O Cerrado é a mais rica entre as savanas do mundo, possui 12.097 espécies de angiospermas (BRAZIL FLORA GROUP, 2015) e mais de 900 espécies de árvores (BRIDGEWATER et al. 2004; RATTER et al. 2003, FRANÇOSO, 2014). Dentre esta elevada diversidade biológica há dezenas de espécies arbóreas com potencial já reconhecido de gerar produtos de valor econômico (SILVA JÚNIOR, 2005; ALMEIDA et al., 1998; IBGE, 2002; CAMPOS FILHO e SARTORELLI, 2015, VIEIRA, et al., 2010) Todavia, ainda há poucas informações acerca das características das árvores nativas para comporem sistemas silvipastoris. Estas espécies tendem a ser mais adaptadas às condições edafo-climáticas locais e contribuírem para conservação cultural e ecológica deste ecossistema bastante ameaçado. Todavia, o aumento da área plantada, pesquisas e tecnologia dos SSP no Cerrado têm sido com foco no uso de espécies exóticas de rápido crescimento, prioritariamente do gênero Eucalipto, em contraposição ao uso de espécies nativas (BUNGENSTAB, 2012; ALVES, 2015).

Neste capítulo foram caracterizadas 23 espécies arbóreas nativas do cerrado lato sensu, frequentes em pastagens, segundo suas características funcionais relacionadas a atributos desejáveis para sistemas silvipastoris. O objetivo é subsidiar técnicos e pecuaristas a escolher as espécies para seus sistemas silvipastoris com maior segurança e embasamento, de acordo com suas realidades, objetivos e preferências. Este trabalho é parte de um objetivo maior de valorização da biodiversidade do cerrado e da agregação de valor de conservação às pastagens do Cerrado, que ocupam $68 \%$ das áreas com uso antrópico no bioma Cerrado. 


\section{MATERIAIS E MÉTODOS}

\section{Espécies estudadas}

Foram selecionadas espécies que tivessem alta frequência e área basal segundo a análise da vegetação do bioma cerrado de Bridgewater e Ratter (2004) e que alcançassem altura mínima de $6 \mathrm{~m}$ quando adultas (SILVA-JUNIOR et al., 2014). Destas, selecionou-se as espécies que se destacavam como frutíferas, madeireiras, medicinais e forrageiras (ALMEIDA et al., 1998; SIIVA-JUNIOR, 2005; IBGE, 2002; CAMPOS FILHO e SARTORELLI, 2015) resultando numa lista de 56 espécies para serem levantadas nas pastagens arborizadas. Porém, após a amostragem de campo foram selecionadas 23 espécies que eram comumente encontradas nas pastagens da região estudada. (Figura 1)

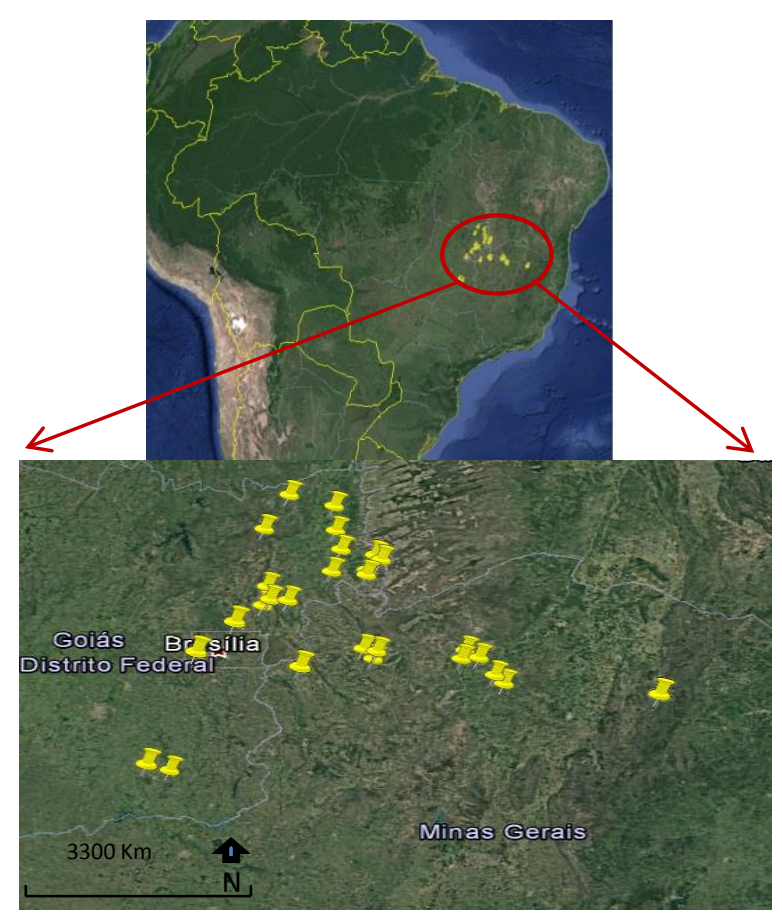

Figura 1: Localização das pastagens onde coletou-se dados das características de 23 espécies arbóreas nativas do cerrado lato sensu frequentes em pastagens, selecionadas para caracterização do potencial para arborizar pastagens.

\section{Coleta de dados}

Foi adotado como pré-requisito na escolha das pastagens que elas deveriam estar em uso e terem sido formadas, ou seja, ter havido o plantio de capim exótico em algum momento. Os dados foram coletados em 27 pastagens localizadas em 16 municípios de Minas Gerais e Goiás (Figura 1). Nas pastagens, os indivíduos das 23 
espécies eram procurados para caracterização. Foram avaliados indivíduos visualmente saudáveis com diâmetro mínimo de $20 \mathrm{~cm}$ a $30 \mathrm{~cm}$ do solo (DA30cm). Cada indivíduo teve sua coordenada geográfica registrada com GPS. O DA30cm foi medido com suta. A medida de altura total, do fuste (altura até a primeira bifurcação) e da base da copa (altura até a primeira folha) foi feita com uma régua extensível graduada em centímetro com altura total de metros. Raras vezes, quando a altura da árvore ultrapassou $12 \mathrm{~m}$ (incluído a altura do medidor com braço levantado mais total da régua), a altura que ultrapassava a régua foi estimada visualmente. Por meio de análise visual as copas das árvores foram classificadas em 8 tipos de formas de copa (colunar, elíptica horizontal, elíptica vertical, umbeliforme, caliciforme, cônica, flabeliforme, e globosa; (SILVA JUNIOR, 2015).Foram descritas a mediana ( ${ }^{\circ}$ e $3^{\circ}$ quartil), mínima e máxima para altura total, altura da base da copa, diâmetro do tronco e área da copa, paca cada uma das 23 espécies.. As análises foram conduzidas no programa Minitab 17 Statistical Software.

Foi estimada a cobertura do solo no pasto sob a copa das árvores e a pleno sol para verificar interferência da árvore em relação ao pasto. Utilizou-se o método de pontos (MANTOVANI e MARTINS, 1990). Foi lançada sobre o solo uma vareta de 2 m com marcações a cada $50 \mathrm{~cm}$; utilizou-se uma antena de TV perpendicular as marcações, para definir a cobertura do solo como: "capim" ou "ausência de capim" (solo, folha, galho, pedra, fezes, erva, regeneração de árvore ou arbusto). De acordo com o que a antena encostasse primeiro definia-se a cobertura do solo no local de cada marcação. Para cada indivíduo foram realizadas a identificação de 20 pontos sob a copa e 20 a pleno sol, com dez repetições por espécie (Figura 2). As medidas foram realizadas entre os meses de maio e setembro. A diferença da cobertura do solo dentro e fora da área de influencia da copa das árvores foi analisada pelo teste t pareado para cada espécie. 

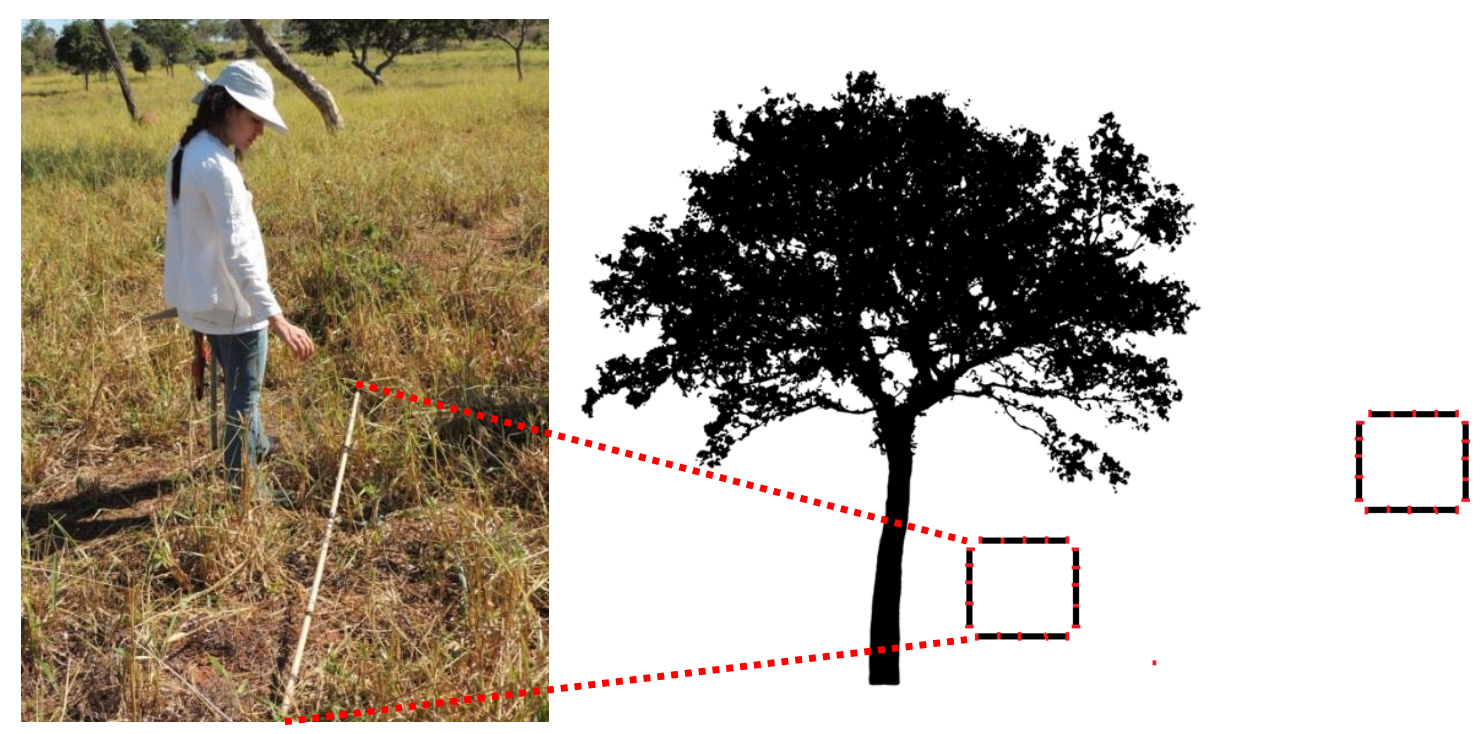

Figura 2: Método para caracterizar a cobertura do solo no pasto a pleno sol e sob as árvores de 23 espécies nativas do cerrado lato sensu frequentes em pastagens, selecionadas para caracterização do potencial para arborizar pastagens.

Para caracterização da densidade da copa, foi mensurada a Radiação Fotossintéticamente Ativa (RFA) com o uso de um sensor linear de um metro de comprimento com 80 sensores (Line Quantum Sensor - LICOR) acoplado a um medidor de luz (LI-250A, LICOR) o qual mediu a densidade de fluxo de fótons (DFF, mmol $\left.\mathrm{m}^{-1} \mathrm{~s}^{-1}\right)$. As medidas de luz foram realizadas entre $10 \mathrm{~h}$ e $14 \mathrm{~h}$, sempre em dias sem nuvens. As medições foram realizadas no auge do período da seca, entre os meses de agosto e setembro e repetida no final do período chuvoso entre os meses de abril e maio. Foram medidas 10 árvores de cada uma das 23 espécies estudadas. Adotou-se o prérequisito de medir indivíduos de grande porte, localizados sem nenhuma árvore próxima para evitar sobreposição da projeção das copas, podiam ou não estar localizadas em pastagens. Cada árvore teve a circunferência medida a $30 \mathrm{~cm}$ do solo com auxílio de fita métrica, tiveram suas coordenadas geográficas anotadas além do registro fotográfico. $\mathrm{O}$ equipamento foi posicionado horizontalmente com uma das extremidades apoiadas em um tripé com altura de $120 \mathrm{~cm}$ do solo. Para cada indivíduo foram efetuadas duas medidas de luz em pontos ao acaso sob a copa das árvores. Utilizou-se a fórmula (RFA sob árvore / RFA pleno sol) *100, para calcular a porcentagem de luz sob a copa das árvores (\%RFA).

Foram realizadas entrevistas estruturadas aos pecuaristas (proprietários ou gerentes) das áreas estudadas, bem como, a revisão de literatura (tabela 1), posteriores à coleta de dados em campo, com o propósito de complementar a caracterização das 
espécies em questão. Quando houve dúvida do entrevistado acerca da espécie a que estávamos nos referindo, o convidávamos ao campo para mostrar a espécie ou mostrávamos fotos contidas em livros. As entrevistas foram gravadas, posteriormente transcritas e organizadas de acordo com os temas e as espécies.

Tabela 1. Relação das características analisadas para as 23 espécies arbóreas estudas e a forma como cada dado será coletado: LC: levantamento em campo; E: entrevistas; RL: revisão de literatura.

\begin{tabular}{|c|c|c|}
\hline Categoria & Característica & $\begin{array}{l}\text { Coleta } \\
\text { de dados }\end{array}$ \\
\hline \multirow{8}{*}{$\begin{array}{l}\text { Potencial de influenciar } \\
\text { diretamente a pastagem }\end{array}$} & Altura total & $\mathrm{LC}$ \\
\hline & $\begin{array}{l}\text { Dimensões da copa (altura da base e } \\
\text { área) }\end{array}$ & $\mathrm{LC}$ \\
\hline & Forma da copa & $\mathrm{LC}$ \\
\hline & Densidade da copa & $\mathrm{LC}$ \\
\hline & Deciduidade & RL \\
\hline & Capacidade de fixação de $\mathrm{N}$ & RL \\
\hline & Associação com micorrizas & RL \\
\hline & Interferência no pasto sob a copa & LC \\
\hline \multirow{2}{*}{$\begin{array}{l}\text { Potencial de influenciar } \\
\text { diretamente os animais }\end{array}$} & Fornecimento de forragem & $\mathrm{E}, \mathrm{RL}$ \\
\hline & $\begin{array}{l}\text { Indícios de partes tóxicas ou } \\
\text { prejudiciais }\end{array}$ & $\mathrm{E}, \mathrm{RL}$ \\
\hline \multirow[t]{3}{*}{$\begin{array}{l}\text { Geração de produtos } \\
\text { madeireiros }\end{array}$} & $\begin{array}{l}\text { Usos na propriedade: cerca, } \\
\text { construções, móveis }\end{array}$ & $\mathrm{E}, \mathrm{RL}$ \\
\hline & Altura do fuste & $\mathrm{LC}$ \\
\hline & Densidade da madeira & $\mathrm{RL}$ \\
\hline \multirow[t]{3}{*}{ Produtos não madeireiros } & Com potencial ou já comercializados & $\mathrm{E} ; \mathrm{RL}$ \\
\hline & Frutos utilizados pelas famílias & $\mathrm{E}$ \\
\hline & Potencial apícola & RL \\
\hline
\end{tabular}

\section{RESULTADOS}

As 23 espécies selecionadas apresentam ampla distribuição nos estados abrangidos pelo bioma Cerrado (BRIDGEWATER, 2004; SILVA-JUNIOR, 2012). Todas ocorrem no cerrado sentido restrito, 3 também ocorrem em formações campestres, 17 no cerradão, 6 na mata de galeria e 4 na mata seca (SILVA-JUNIOR, 2012; ALMEIDA et al., 1998; IBGE,2002) (Tabela 2).

\section{Características das árvores}

\section{Arquitetura da copa}

As árvores mais altas foram C. langsdorffi, P. pubescens, B. virgilioides com mediana de 11,3m a primeira e 10,8 $\mathrm{m}$ as duas últimas (Figura 3). As espécies de menor porte foram $E$. dysenterica, com mediana de $6,7 \mathrm{~m}$ seguida de $A$. tomentosa e $C$. americana ambas com $7,1 \mathrm{~m}$. A altura média até a base da copa, considerando as 23 
espécies foi de 2,7 m ( $\pm 1,2)$ (As copas mais elevada foram de $M$. urundeuva, seguida por $T$. aurea e A. fraxinifolium com mediana de 3,5; 3,4 e 3,1 m respectivamente e as mais baixas foram $Q$. parviflora $(1,6 \mathrm{~m})$ A. crassiflora $(1,5 \mathrm{~m})$, C. brasiliense $(1,8 \mathrm{~m})$. A espécie C. langsdorffii apresentou a maior área de copa (237 $\mathrm{m}^{2}$ de mediana), possivelmente é uma característica dessa espécie, mas deve estar sendo influenciada neste estudo por termos amostrado indivíduos com elevados valores de diâmetro da base $(52,7 \mathrm{~cm})$, ou seja, indivíduos mais antigos. Outras duas espécies que tiveram maior área de copa foram $T$. argentea $\left(75 \mathrm{~m}^{2}\right)$ e $C$. brasiliense $\left(67 \mathrm{~m}^{2}\right)$. As menores áreas de copa foram de Q. parviflora, A. crassiflora, E. dysenterica com áreas de 19;20 e $22 \mathrm{~m}^{2}$, respectivamente (Figura 3). Houve uma grande variação dos formatos de copa entre indivíduos de uma mesma espécie, portanto, os formatos apresentados na tabela 02 são formatos mais frequentes.

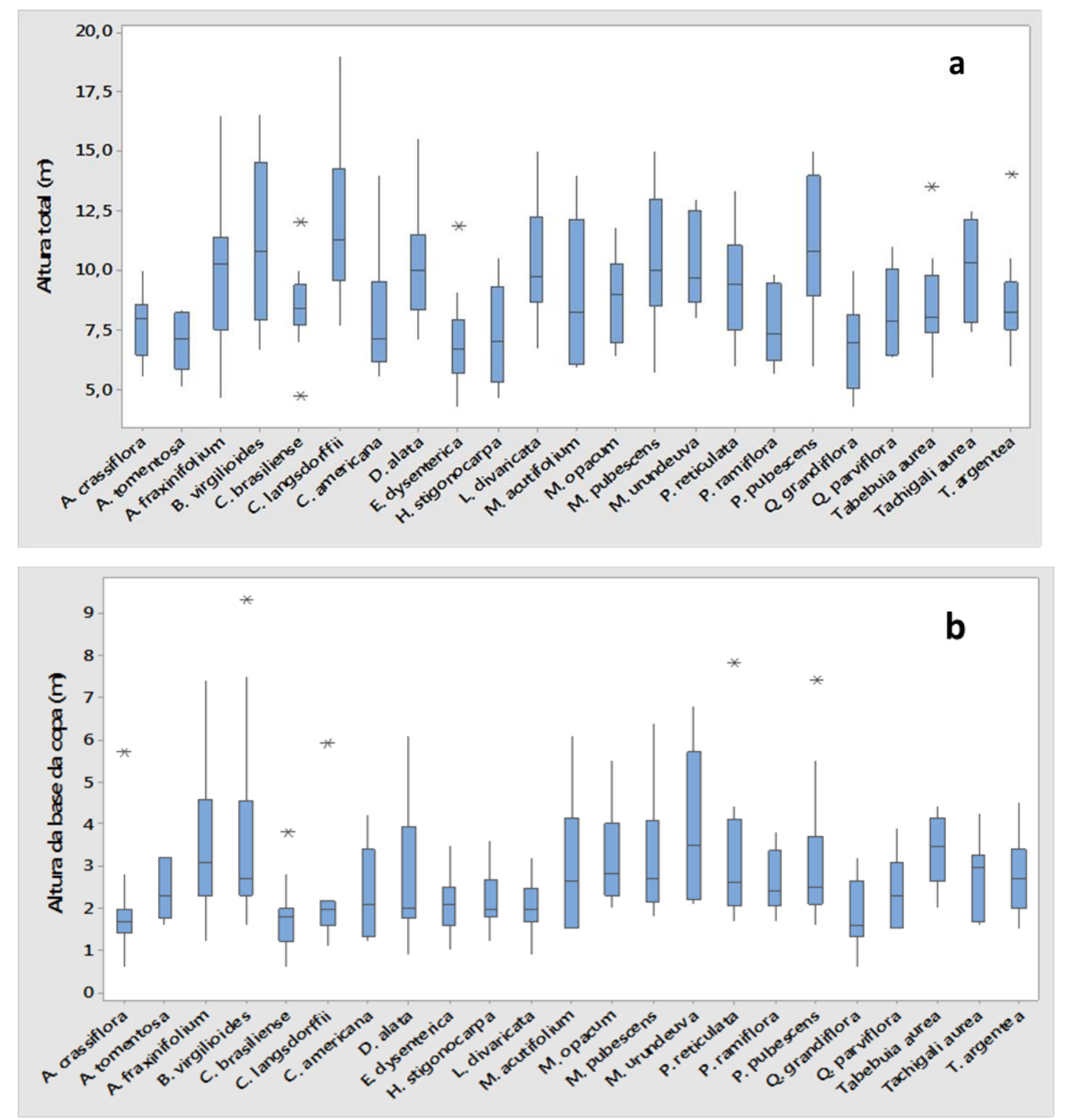



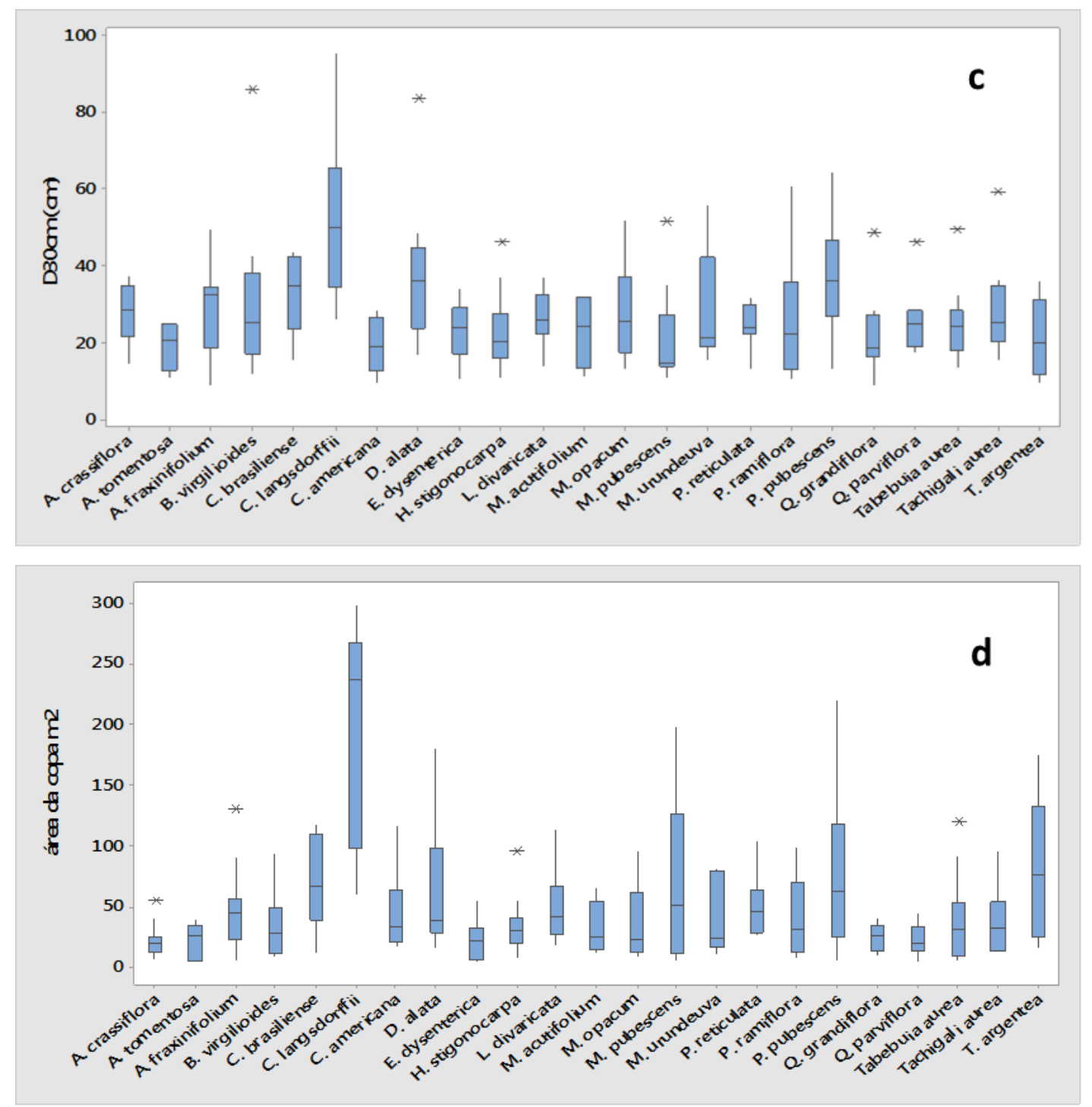

Figura 3: Característica da arquitetura de copa de 23 espécies arbóreas nativas do cerrado lato sensu, frequentes em pastagens, selecionadas para caracterização do potencial para arborizar pastagens. a- altura total das árvores; b- altura da base da copa, ou seja, das folhas mais baixas da copa; c- diâmetro medido a $30 \mathrm{~cm}$ do solo; d- área da copa. A mediana é representada pelo traço preto dentro da caixa, o $1^{\circ}$ e $3^{\circ}$ quartil os extremos da caixa, o máximo e mínimo são o extremo dos traços fora das caixas e os asteriscos são valores discrepantes. 
Tabela 2: Caracterização de 23 espécies arbóreas nativas do cerrado segundo parâmetros de interesse para arborização de pastagens.

\begin{tabular}{|c|c|c|c|c|c|c|c|c|c|}
\hline Espécie & $\begin{array}{l}\text { Nome } \\
\text { popular }\end{array}$ & Família & Habitat & Ocorrência & $\begin{array}{l}\text { Ra } \\
\text { nq. } \\
\text { IV } \\
\text { I }^{*}\end{array}$ & Fenologia & $\begin{array}{l}\text { Formato } \\
\text { predominant } \\
\text { e/secundário }\end{array}$ & Fixa $\mathbf{N}$ & $\begin{array}{l}\text { Micorrizas (sim/não) } \\
\text { Incidência (I); } \\
\text { dependência (D) }\end{array}$ \\
\hline Annona crassiflora Marti & Araticum & Annonaceae & $\begin{array}{l}\text { cer;cão; } \\
\text { car }^{1}\end{array}$ & $\begin{array}{l}\text { BA;DF;GO;MA;MG;MS; } \\
\text { MT;PA;PI;SP;TO }{ }^{1}\end{array}$ & $6^{\circ}$ & $\begin{array}{l}\text { Decídua }^{4,3,} \\
2\end{array}$ & elíp. vertical & $\bar{x}$ & $\operatorname{Sim}^{37}$ I-baixa ${ }^{37}$ \\
\hline $\begin{array}{l}\text { Aspidosperma tomentosum } \\
\text { Mart. }\end{array}$ & $\begin{array}{l}\text { Peroba do } \\
\text { cerrado }\end{array}$ & Apocynaceae & cer;cão ${ }^{1}$ & $\begin{array}{l}\text { AC,BA,DF,GO,MA;MG; } \\
\text { MS;MT;PE;PI;PR;RJ;SC; } \\
\text { SP;TO }{ }^{1}\end{array}$ & $\begin{array}{l}23 \\
0\end{array}$ & Decídua $^{4,3}$ & globosa & $\mathrm{x}$ & $\begin{array}{l}\text { I-baixa }(9 \%)^{38 ;} \mathrm{D}- \\
\text { média }^{35}\end{array}$ \\
\hline $\begin{array}{l}\text { Astronium fraxinifolium } \\
\text { Schott }\end{array}$ & $\begin{array}{l}\text { Gonçalo- } \\
\text { Alves }\end{array}$ & Anacardiaceae & $\begin{array}{l}\text { cer;cão; } \\
\text { mas }^{2}\end{array}$ & $\begin{array}{l}\text { AP,CE,DF,GO,MA;MT, } \\
\text { MS;MG;PA,PE,PI,SP,TO }{ }^{2}\end{array}$ & $8^{\circ}$ & $\begin{array}{l}\text { Decídua } \\
4,3,8\end{array}$ & $\begin{array}{l}\text { elíp. horiz./ } \\
\text { vertical }\end{array}$ & $\mathrm{x}$ & $\operatorname{Sim}^{38 ;}$ I-alta $(89 \%)^{38}$ \\
\hline $\begin{array}{l}\text { Bowdichia virgilioides } \\
\text { Kunth. }\end{array}$ & $\begin{array}{l}\text { Sucupira } \\
\text { preta }\end{array}$ & Fabaceae & $\begin{array}{l}\text { cer;cão; } \\
\text { mag }^{1}\end{array}$ & $\begin{array}{l}\text { AP,CE,DF,GO,MA,MG, } \\
\text { MS,MT,PA,PE,PI,SP,TO }\end{array}$ & $4^{\circ}$ & $\begin{array}{l}\text { Semi- } \\
\text { decídua }^{\text {a }} \\
4,10 / \text { decídua }_{11,12}\end{array}$ & $\begin{array}{l}\text { elíp. vertical/ } \\
\text { flabeliforme }\end{array}$ & $\operatorname{sim}_{27,28}^{21}$ & $\operatorname{Sim}^{38 ;}$ I-alta $(82 \%)^{38}$ \\
\hline $\begin{array}{l}\text { Caryocar brasiliense } \\
\text { Cambess }\end{array}$ & Pequi & Caryocaraceae & cer;cão $^{1}$ & $\begin{array}{l}\text { BA;CE;DF;GO;MA;MG; } \\
\text { MT;PA;RJ;SP;TO }{ }^{1}\end{array}$ & $1^{\circ}$ & $\begin{array}{l}\text { Semi- } \\
\text { decídua }^{a} \\
4,2,8 / \text { decídu } \\
a^{3}\end{array}$ & elíp. horiz. & $\mathrm{x}$ & $\begin{array}{l}\operatorname{sim}^{35,37,38} \text { I-baixa }^{35,37} \\
\text { a média }(68 \%)^{38}\end{array}$ \\
\hline Copaifera langsdorffii Desf & Copaíba & Fabaceae & $\begin{array}{l}\text { cer;cão; } \\
\text { mag }^{1}\end{array}$ & $\begin{array}{l}\text { CE;DF;MA;MG;MS;MT; } \\
\text { PA;PR;SP }\end{array}$ & $\begin{array}{l}18 \\
0\end{array}$ & $\begin{array}{l}\text { Sempre } \\
\text { verde }^{\text {a } 4,12 /} \\
\text { semi- } \\
\text { decídua } \\
11,14\end{array}$ & umbeliforme & não ${ }_{31,33,34}^{25}$ & $\begin{array}{l}\operatorname{sim}^{35,36,37} \text { I-baixa }^{37} \text { a } \\
\text { alta }(89 \%)^{38,} \text { D-não } \\
\text { possui }^{35}\end{array}$ \\
\hline Curatella americana $L$. & Lixeira & Dilleniaceae & $\begin{array}{l}\text { cer;cão;c } \\
\text { ar,cas }^{1}\end{array}$ & $\begin{array}{l}\text { AL;AM;AP;BA;CE;DF;G } \\
\text { O;MA;MG;MS;MT;PA;P } \\
\text { B;PE;PI;RN;RO;RR;SE;T } \\
\mathrm{O}^{1}\end{array}$ & 10 & $\begin{array}{l}\text { Semi- } \\
\text { decídua } \\
4,8,13 / \\
\text { decídua }^{3}\end{array}$ & globosa & $\mathrm{x}$ & $\mathrm{x}$ \\
\hline Dipteryx alata Vogel & Baru & Fabaceae & $\begin{array}{l}\text { cer;cão; } \\
\operatorname{mas}^{1}\end{array}$ & $\begin{array}{l}\text { BA;CE;DF;GO;MA;MG; } \\
\text { MS;MT;PI;SP;TO }{ }^{1}\end{array}$ & $2^{\circ}$ & $\begin{array}{l}\text { Sempre } \\
\text { verde }^{\mathrm{a}} \\
4,8,10 / \text { semi- }^{1-} \\
\text { decídua }^{14}\end{array}$ & $\begin{array}{l}\text { globosa / } \\
\text { elíp. horiz. }\end{array}$ & não $_{29,34}^{22,}$ & $\operatorname{sim}^{37}$ I-baixa ${ }^{3}$ \\
\hline Eugenia dysenterica $D C$. & Cagaita & Myrtaceae & cer;cão $^{1}$ & $\begin{array}{l}\text { BA;CE;DF;GO;MA;MG; } \\
\text { MS:MTPI;SP;TO }{ }^{1}\end{array}$ & $7^{\circ}$ & ${ }_{8}{ }^{2 e c i ́ d u a ~}{ }^{4,2}$ & $\begin{array}{l}\text { globosa / } \\
\text { elíp. vertical }\end{array}$ & $\mathrm{x}$ & $\mathrm{x}$ \\
\hline
\end{tabular}




\begin{tabular}{|c|c|c|c|c|c|c|c|c|c|}
\hline $\begin{array}{l}\text { Hymenaea stigonocarpa } \\
\text { Mart. }\end{array}$ & Jatobá & Fabaceae & cer;cão ${ }^{1}$ & $\begin{array}{l}\text { AM;BA;CE;DF;GO;MA; } \\
\text { MG;MS;MT;SP;TO }\end{array}$ & $9^{\circ}$ & Decídua $^{8,9}$ & $\begin{array}{l}\text { globosa/ } \\
\text { elíp. horiz }\end{array}$ & $\begin{array}{l}\text { não }_{21,23,24}^{20,} \\
21\end{array}$ & $\begin{array}{l}\text { Sim }^{37,38} \text { I-baixa }^{37} \text { a } \\
\text { alta }(86 \%)^{38 ;} \text { D-não } \\
\text { possui }{ }^{1}\end{array}$ \\
\hline Luehea divaricata Mart. & $\begin{array}{l}\text { Açoita } \\
\text { cavalo }\end{array}$ & Malvaceae & $\begin{array}{l}\text { cer;cão, } \\
\text { mas; } \\
\text { mag }^{3}\end{array}$ & $\begin{array}{l}\text { BA;CE;DF,ES;GO,MT;M } \\
\text { S;PE;PR;RJ;RS;SC;SP;T } \\
\mathrm{O}^{3}\end{array}$ & $\begin{array}{l}24 \\
0\end{array}$ & $\begin{array}{l}\text { Decídua } \\
15\end{array}$ & $\begin{array}{l}\text { elíp. horiz./ } \\
\text { elíp. vertical }\end{array}$ & $\mathrm{x}$ & $\operatorname{Sim}^{35}$ D-alta ${ }^{35}$ \\
\hline $\begin{array}{l}\text { Machaerium acutifolium } \\
\text { Vogel }\end{array}$ & $\begin{array}{l}\text { Jacarand } \\
\text { á bico de } \\
\text { papagaio }\end{array}$ & Fabaceae & cer;cão ${ }^{1}$ & $\begin{array}{l}\mathrm{BA} ; \mathrm{CE} ; \mathrm{DF} ; \mathrm{GO} ; \mathrm{MS} ; \mathrm{MT} ; \mathrm{S} \\
{\mathrm{P} ; \mathrm{TO}^{1}}^{1}\end{array}$ & $\begin{array}{l}54 \\
0\end{array}$ & $\begin{array}{l}\text { Sempre } \\
\text { verde }^{\text {a } 4,1 /} \\
\text { semi- } \\
\text { decídua }^{5}\end{array}$ & elíp. vertical & $\operatorname{sim}_{33}^{30}$ & Não ${ }^{37} / \mathrm{Sim}^{38}$ \\
\hline $\begin{array}{l}\text { Machaerium opacum } \\
\text { Vogel }\end{array}$ & $\begin{array}{l}\text { Jacarand } \\
\text { á } \\
\text { cascudo }\end{array}$ & Fabaceae & cer;cão ${ }^{1}$ & BA;DF;GO;MG;MT;TO ${ }^{1}$ & $\begin{array}{l}17 \\
0\end{array}$ & $\begin{array}{l}\text { Sempre } \\
\text { verde }^{1}\end{array}$ & $\begin{array}{l}\text { globosa/ } \\
\text { elíp. horiz. }\end{array}$ & $\begin{array}{l}\text { n.d. } \\
(\operatorname{sim})^{2} \\
1,25,26\end{array}$ & $\mathrm{x}$ \\
\hline $\begin{array}{l}\text { Magonia pubescens A.St.- } \\
\text { Hil. }\end{array}$ & Tingui & Sapindaceae & $\begin{array}{l}\text { cer;cão; } \\
\text { mas }^{1}\end{array}$ & $\begin{array}{l}\text { BA;CE;DF;GO;MA;MG; } \\
\text { MS; MT;PA;PI;SP;TO }{ }^{1}\end{array}$ & $5^{\circ}$ & Decídua $^{3,8}$ & $\begin{array}{l}\text { globosa / } \\
\text { elíp. horiz. }\end{array}$ & $\mathrm{x}$ & $\operatorname{Sim}^{38}$ I-alta $(89 \%)^{38}$ \\
\hline $\begin{array}{l}\text { Myracrodruon urundeuva } \\
\text { Allemão }\end{array}$ & Aroeira & $\begin{array}{l}\text { Anacardiacea } \\
\text { e }\end{array}$ & $\begin{array}{l}\text { cer;cão; } \\
\operatorname{mas}^{1}\end{array}$ & $\begin{array}{l}\text { BA;CE;DF;GO;MA;MG; } \\
\text { MS;MT;PA;PE;PI;RJ;SP; } \\
\text { TO }^{1}\end{array}$ & 13 & $\begin{array}{l}\text { Decídua }{ }^{3,2}, \\
\end{array}$ & elíp. vertical & $\mathrm{x}$ & $\operatorname{Sim}^{38,}$ I-alta $(89 \%)^{38}$ \\
\hline $\begin{array}{l}\text { Plathymenia reticulata } \\
\text { Benth. }\end{array}$ & $\begin{array}{l}\text { Vinhátic } \\
\text { o }\end{array}$ & Fabaceae & cer;cão ${ }^{1}$ & $\begin{array}{l}\text { ampla distribuição } \\
\text { nacional }^{1}\end{array}$ & $\begin{array}{l}20 \\
\text { o }\end{array}$ & ${ }_{9}^{\text {Decídua }}$ & elíp. horiz. & $\operatorname{sim}_{27,19}^{21}$ & $\mathrm{x}$ \\
\hline $\begin{array}{l}\text { Pouteria ramiflora (Mart.) } \\
\text { Radlk. }\end{array}$ & Curiola & Sapotaceae & $\begin{array}{l}\text { cer;cão; } \\
\operatorname{mag}^{1}\end{array}$ & $\begin{array}{l}\text { BA;CE;DF;GO;MA;MG; } \\
\text { MS;MT;PA;PE;PI;RJ;RO; } \\
\text { SP;TO }^{1}\end{array}$ & $\begin{array}{l}29 \\
0\end{array}$ & $\begin{array}{l}\text { Semi- } \\
\text { decídua }^{4,2,8}\end{array}$ & elíp. horiz. & $\mathrm{x}$ & $\operatorname{Sim}^{38,}$ I-alta $(80 \%)^{38}$ \\
\hline Pterodon pubescens Benth & $\begin{array}{l}\text { Sucupira } \\
\text { branca }\end{array}$ & Fabaceae & cer;cão ${ }^{1}$ & $\mathrm{DF} ; \mathrm{GO} ; \mathrm{MG} ; \mathrm{MS} ; \mathrm{SP}^{1}$ & $3^{\circ}$ & Decídua $^{9}$ & $\begin{array}{l}\text { globosa / } \\
\text { elíp. horiz. }\end{array}$ & não ${ }^{21}$ & $\operatorname{sim}^{37}$ I-baixa ${ }^{37}$ \\
\hline Qualea grandiflora Mart. & $\begin{array}{l}\text { Pau terra } \\
\text { grande }\end{array}$ & Vochysiaceae & $\begin{array}{l}\text { cer;cão; } \\
\text { cas;car }^{1}\end{array}$ & $\begin{array}{l}\text { AC;AM;BA;CE;DF;GO; } \\
\text { MA;MG;MT;PA;PI;PR;S } \\
\text { P;TO }\end{array}$ & 12 & $\begin{array}{l}\text { Decídua } \\
4,17,18\end{array}$ & globosa & $\mathrm{x}$ & $\begin{array}{l}\text { Não }{ }^{37} / \operatorname{sim}^{38} \text { I-média } \\
(68 \%)^{38}\end{array}$ \\
\hline Qualea parviflora Mart. & $\begin{array}{l}\text { Pau terra } \\
\text { roxo }\end{array}$ & Vochysiaceae & $\begin{array}{l}\text { cer;cão; } \\
\operatorname{cas}^{1}\end{array}$ & $\begin{array}{l}\text { AM;BA;CE;DF;GO;MA; } \\
\text { MG;MT;PA;PI;SP;TO }{ }^{1}\end{array}$ & $\begin{array}{l}14 \\
0\end{array}$ & $\begin{array}{l}\text { Decídua } \\
4,17,19\end{array}$ & globosa & $\mathrm{x}$ & $\mathrm{x}$ \\
\hline Tabebuia aurea & $\begin{array}{l}\text { Ipê } \\
\text { caraíba }\end{array}$ & Bignoniaceae & cer,mag ${ }^{1}$ & $\begin{array}{l}\text { AM;AP;BA;CE;DF;GO; } \\
\text { MA;MS;SP;TO }{ }^{1}\end{array}$ & 15 & Decídua $^{4,2}$ & $\begin{array}{l}\text { elíp. horiz. / } \\
\text { globosa }\end{array}$ & $\mathrm{x}$ & $\begin{array}{l}\text { Sim }^{37} \\
\text { I-alta }^{37}\end{array}$ \\
\hline Tachigali subvelutina Tul & $\begin{array}{l}\text { Carvoeir } \\
\text { o }\end{array}$ & Fabaceae & cer;cão ${ }^{1}$ & BA;GO;MG;MT;SP;TO ${ }^{1}$ & $\begin{array}{l}28 \\
0\end{array}$ & $\begin{array}{l}\text { Sempre } \\
\text { verde }^{4,1,10}\end{array}$ & $\begin{array}{l}\text { globosa/ } \\
\text { elíp. horiz. }\end{array}$ & $\operatorname{sim}_{32}^{29}$ & $\mathrm{x}$ \\
\hline Terminalia argentea & Capitão & Combretaceae & $\begin{array}{l}\text { cer;cão; } \\
\text { cas;mag }\end{array}$ & DF;GO;MG;MS;SP ${ }^{1}$ & 11 & Decídua $^{3}$ & $\begin{array}{l}\text { elíp. horiz / } \\
\text { caliciforme }\end{array}$ & $\mathrm{x}$ & $\mathrm{x}$ \\
\hline
\end{tabular}




\begin{tabular}{|c|c|c|c|c|c|c|c|c|c|}
\hline Espécie & $\begin{array}{l}\text { Forrageira - } \\
\% \text { dos } \\
\text { pecuaristas que } \\
\text { citaram }\end{array}$ & $\begin{array}{l}\text { Proteín } \\
\text { a } \\
\text { bruta( } \\
\%)\end{array}$ & OBS forrageiras & $\begin{array}{l}\text { Usos -\% dos } \\
\text { pecuaristas que } \\
\text { citaram / } \\
\text { consomem (C) }\end{array}$ & $\begin{array}{l}\text { Densi } \\
\text { d.bási } \\
\text { ca } \\
\text { (g.c } \\
\text { m3) }\end{array}$ & $\begin{array}{l}\text { Alt } \\
\text { fust } \\
\text { e } \\
\text { (m) }\end{array}$ & $\begin{array}{l}\text { OBS. } \\
\text { madeiras }\end{array}$ & $\begin{array}{l}\text { Usos não } \\
\text { madeireiro } \\
\text {-\% } \\
\text { pecuaristas } \\
\text { que } \\
\text { consomem }\end{array}$ & $\begin{array}{l}\text { Obs. } \\
\text { melíferas }\end{array}$ \\
\hline $\begin{array}{l}\text { Annona crassiflora } \\
\text { Marti }\end{array}$ & Fruto-7\% & $1,3^{49}$ & & & & & & $\begin{array}{l}\text { Fruto }^{60,94,59}- \\
39 \%\end{array}$ & \\
\hline $\begin{array}{l}\text { Aspidosperma } \\
\text { tomentosum Mart. }\end{array}$ & $\mathrm{x}$ & $\mathrm{x}$ & $\mathrm{x}$ & $\begin{array}{l}\text { Cerca }^{8,3,45}-20 \% \\
\text { Construçãoo } \\
\text { móveis }^{3,67}-20 \%\end{array}$ & $\begin{array}{l}0,6- \\
0,8^{8,78}\end{array}$ & 3,0 & $\begin{array}{l}\text { Fácil de } \\
\text { trabalhar }^{3} \\
\text { Flexível }^{67}\end{array}$ & $\operatorname{Mel}^{1}$ & \\
\hline $\begin{array}{l}\text { Astronium } \\
\text { fraxinifolium Schott }\end{array}$ & Folha ${ }^{39,54}$ & $12^{54}$ & & $\begin{array}{l}\text { Cerca }{ }^{5,3,7}-40 \% \\
\text { construção }^{5,3,7}-20 \% \\
\text { móveis }^{3,7}-10 \% \\
\text { ponte, cocho, curral }^{3}\end{array}$ & $\begin{array}{l}0,9- \\
1^{5,77}\end{array}$ & 4,0 & $\begin{array}{l}\text { Resistente } \\
\text { a } \\
\text { microrganis } \\
\text { mos }^{3,6} \text {; } \\
\text { muito } \\
\text { durável }^{5,62}\end{array}$ & $\mathrm{Mel}_{3,21}^{80,81,45,82,8}$ & $\begin{array}{l}\text { Grande } \\
\text { potencial } \\
\text { apícola }\end{array}$ \\
\hline $\begin{array}{l}\text { Bowdichia virgilioides } \\
\text { Kunth. }\end{array}$ & $\begin{array}{l}\text { Folha }^{45,54,55-} \\
13 \%\end{array}$ & $18^{54}$ & Pouco pastada ${ }^{45.55}$ & $\begin{array}{l}\text { Cerca }^{75}-20 \% \\
\text { Construção } \\
\text { Móveis }{ }^{1,9,7,74}-30 \%\end{array}$ & $0,9^{76}$ & 3,9 & $\begin{array}{l}\text { Resistência } \\
\text { xilófagos } \\
\text {; muito } \\
\text { durável }^{5}\end{array}$ & $\underset{6}{\operatorname{Mel}^{81,84,85,93,6}}$ & $\begin{array}{l}\text { Produz pólen }{ }^{\mathrm{c}} \\
\text { e néctar }\end{array}$ \\
\hline $\begin{array}{l}\text { Caryocar brasiliense } \\
\text { Cambess }\end{array}$ & $\begin{array}{l}\text { Fruto }^{45,58}-43 \% * \\
\text { Flor - 30\% } \\
\text { Folha }^{39,2}-20 \%\end{array}$ & $\begin{array}{l}6^{60,61} \\
\text { casca } \\
\text { do } \\
\text { fruto }\end{array}$ & $\begin{array}{l}\text { Pode influenciar o } \\
\text { cheiro e a cor do } \\
\text { leite }^{55}\end{array}$ & $\begin{array}{l}\text { Cerca }^{3}-70 \% \\
\text { Construção } \\
\text { móveis }{ }^{3}-30 \% \\
\text { curral, cocho } \\
3\end{array}$ & $\begin{array}{l}0,6- \\
0,9^{3,69,7} \\
8\end{array}$ & 2,7 & $\begin{array}{l}\text { Boa } \\
\text { durabilidad } \\
\text { e natural }^{5,3}\end{array}$ & $\begin{array}{l}\text { Mel }^{81,82,86,92,6} \\
\text { Fruto } \\
: 89,60,94,95 \\
: 82 \%\end{array}$ & \\
\hline $\begin{array}{l}\text { Copaifera langsdorffii } \\
\text { Desf. }\end{array}$ & Folha $^{54}-15 \%$ & $11^{54}$ & & $\begin{array}{l}\text { Construção }{ }^{1,5},-40 \% \\
\text { móveis }^{1,5}-20 \%\end{array}$ & $0,7^{69}$ & 4,0 & $\begin{array}{l}\text { Resistente } \\
\text { a fungos } \\
\text { mas não a } \\
\text { cupins } 63\end{array}$ & $\begin{array}{l}\mathrm{Mel}^{81,86,87,88,9} \\
\text { Medicinal } \\
\text { 6,97 }\end{array}$ & $\begin{array}{l}\text { Produz néctar } \\
\text { e muito pólen } \\
\text { (1, }\end{array}$ \\
\hline Curatella americana $\mathrm{L}$. & $\begin{array}{l}\text { Folha }{ }^{40,44,45,30,54,} \\
55-7 \%\end{array}$ & 8 a $9^{45,54}$ & $\begin{array}{l}\text { Folhas novas bem } \\
\text { aceitas }\end{array}$ & & & & & $\operatorname{Mel}^{81,48}$ & $\begin{array}{l}\text { Grande } \\
\text { potencial } \\
\text { apícola }^{48,92}\end{array}$ \\
\hline Dipteryx alata Vogel & $\begin{array}{l}\text { Fruto } 42,44,45,55, \\
56-73 \% \\
\text { Folha }{ }^{42,44,45,55,} \\
56-32 \%\end{array}$ & $\begin{array}{l}12,4 \\
\text { folha }^{56} \\
5,6 \\
\text { polpa }^{49}\end{array}$ & $\begin{array}{l}\text { Folhas bem } \\
\text { aceitas } 45,55 \\
\text { Ingerem fruto e } \\
\text { eliminam o }\end{array}$ & $\begin{array}{l}\text { Cerca }^{5,65,70}-100 \% \\
\text { construção } \\
\text { móveis- }^{5,70}-40 \% \\
\text { ponte }^{7}\end{array}$ & $0,9^{69}$ & 4,1 & $\begin{array}{l}\text { Alta } \\
\text { resistência } \\
\text { a } \\
\text { xilófagos } 5,\end{array}$ & $\begin{array}{l}\text { mel }^{64,92} ; \\
\text { fruto } \\
-28,60,94,95 \\
-28 \%\end{array}$ & \\
\hline
\end{tabular}




\begin{tabular}{|c|c|c|c|c|c|c|c|c|c|}
\hline & & & $\begin{array}{l}\text { caroço }{ }^{30} \text { Polpa } \\
\text { boa para ração }\end{array}$ & & & & 63,70 & & \\
\hline $\begin{array}{l}\text { Eugenia dysenterica } \\
\text { DC. }\end{array}$ & $\begin{array}{l}\text { Fruto }^{39,51,47}- \\
60 \% \\
\text { Folha }^{39,51,47}-7 \%\end{array}$ & $\begin{array}{l}0,1 \\
\text { fruto }^{60}\end{array}$ & & & & & & $\begin{array}{l}\text { Fruto }^{60}, 94,59- \\
40 \% \\
\mathrm{mel}^{81,89,48,}\end{array}$ & \\
\hline $\begin{array}{l}\text { Hymenaea } \\
\text { stigonocarpa Mart. }\end{array}$ & $\begin{array}{l}\text { Fruto - } 47 \% \\
\text { Folha } 39,40,45,54,55- \\
10 \%\end{array}$ & $\begin{array}{l}13,8 \\
\text { folha }^{54} \\
6,4 \\
\text { fruto }^{60}\end{array}$ & Pouco pastada ${ }^{45,55}$ & $\begin{array}{l}\text { Cerca }^{1,7}-50 \% \\
\text { Construção } \\
40 \% \\
\text { Móveis }^{76}-30 \% \\
\text { Curral, ponte }^{1}\end{array}$ & $\begin{array}{l}0,8- \\
0,9^{9,69,7} \\
8\end{array}$ & 2,9 & $\begin{array}{l}\text { Moderadam } \\
\text { ente durável } \\
\text { quando } \\
\text { exposto } \\
\text { resistente a } \\
\text { xilófogos } \\
63\end{array}$ & $\begin{array}{l}\text { Fruto }^{59,60,94,97,} \\
98-21 \% \\
\text { mel }^{9,66} \\
\text { medicinal }\end{array}$ & \\
\hline $\begin{array}{l}\text { Luehea divaricata } \\
\text { Mart. }\end{array}$ & Folha ${ }^{45,56^{*}}-10 \%$ & & Pouco pastada ${ }^{46}$ & $\begin{array}{l}\text { Cerca }{ }^{64,70}-0 \% \\
\text { Construção }^{5,74}-30 \%{ }^{\mathrm{d}} \\
\text { Móveis }^{3,64,70,74}-20 \%\end{array}$ & $\begin{array}{l}0,6- \\
0,7^{69,70}\end{array}$ & 3,7 & $\begin{array}{l}\text { Muito } \\
\text { flexível }{ }^{5,3,74} \text {, } \\
\text { pouco } \\
\text { resistente ao } \\
\text { apodrecime } \\
\text { nto }\end{array}$ & $\mathrm{mel}^{81,64,90,66}$ & $\begin{array}{l}\text { Muito } \\
\text { frequentd }^{3} ; \\
\text { Produz pólen }^{\text {c }} \\
\text { e néctar } \\
\text { medicinal }^{64}\end{array}$ \\
\hline $\begin{array}{l}\text { Machaerium } \\
\text { acutifolium Vogel }\end{array}$ & $\mathrm{x}$ & $\mathrm{x}$ & $\mathrm{x}$ & $\begin{array}{l}\text { Cerca-30\% } \\
\text { construção } 5,7,67,71-0 \% \\
\text { móveis }{ }^{5,7,67,71-}-30 \%\end{array}$ & $1,1^{5,1}$ & 3,5 & $\begin{array}{l}\text { Durável e } \\
\text { resistente } \\
71\end{array}$ & $\mathrm{Mel}^{48}$ & \\
\hline $\begin{array}{l}\text { Machaerium opacum } \\
\text { Vogel }\end{array}$ & $\mathrm{x}$ & $\mathrm{x}$ & $\mathrm{x}$ & $\begin{array}{l}\text { Cerca }{ }^{1-} 20 \% \\
\text { Construçãa } 5,67 \\
\text { Móveis }^{1,67}-80 \%\end{array}$ & $0,9^{69}$ & 3,2 & Durável $^{1}$ & & \\
\hline $\begin{array}{l}\text { Magonia pubescens } \\
\text { A.St.-Hil. }\end{array}$ & $\begin{array}{l}\text { Folha }{ }^{39,45} 20 \% \\
\text { Semente } 20 \%\end{array}$ & $\mathrm{x}$ & $\mathrm{x}$ & $\begin{array}{l}\text { Cerca } 5,3,67,72-30 \% \\
\text { construção } \\
5,3,70-0 \%\end{array}$ & $0,8^{3,72}$ & 2,9 & $\begin{array}{l}\text { Resistente a } \\
\text { xilófagos } 5,3\end{array}$ & $\operatorname{Mel}^{81,1,66}$ & Mel tóxico ${ }^{45,91}$ \\
\hline $\begin{array}{l}\text { Myracrodruon } \\
\text { urundeuva Allemão }\end{array}$ & $\begin{array}{l}\text { Folha }{ }^{41,42,45,46,52-} \\
20 \%\end{array}$ & $\begin{array}{l}18 \mathrm{a} \\
20,5 \\
52,54\end{array}$ & $\begin{array}{l}\text { Regularmente } \\
\text { podada para } \\
\text { forragem, pode } \\
\text { ser mantida na } \\
\text { forma arbustiva } \\
54\end{array}$ & $\begin{array}{l}\text { Cerca, }{ }^{3,64,46,68}-100 \% \\
\text { construçãa }^{3,64,46,70}- \\
0 \% \\
\text { móveis }^{3,64,46,70} \text { - } \\
0 \% ; \text { curral, cocho, }^{3,46}\end{array}$ & $\begin{array}{l}1- \\
1,2^{46,68}\end{array}$ & 4,8 & $\begin{array}{l}\text { Das mais } \\
\text { resistentes } \\
\text { do Brasil e } \\
\text { do mundo } \\
3,46,70,5,68\end{array}$ & $\begin{array}{l}\text { Mel }^{81,68,48,64,46,} \\
\text { Medicinal }^{97,99}\end{array}$ & $\begin{array}{l}\text { grande } \\
\text { potencial } \\
\text { apícola }^{48} \text {; } \\
\text { Importante } \\
\text { para abelhas } \\
\text { nativas }^{46}\end{array}$ \\
\hline $\begin{array}{l}\text { Plathymenia reticulata } \\
\text { Benth. }\end{array}$ & $\begin{array}{l}\text { Folha }{ }^{39,41,45,57}- \\
15 \%\end{array}$ & $14,9^{54}$ & Pouco pastada ${ }^{45}$ & $\begin{array}{l}\text { cerca }^{46,45,70,74-100 \%} \\
\text { construção } \\
20 \% \\
\text { móveis }^{5,15,67,70-67,70-} 50 \% \text {; } \\
\text { curral }^{45}\end{array}$ & $0,6^{1,70}$ & 3,6 & $\begin{array}{l}\text { Muito } \\
\text { resistente a } \\
\text { xilófago }\end{array}$ & $\mathrm{Mel}^{86,48,1}$ & \\
\hline
\end{tabular}




\begin{tabular}{|c|c|c|c|c|c|c|c|c|c|}
\hline $\begin{array}{l}\text { Pouteria ramiflora } \\
\text { (Mart.) Radlk. }\end{array}$ & $\begin{array}{l}\text { Folhas }^{45} \\
\text { Fruto } 20 \%\end{array}$ & $9,5^{54}$ & Pouco pastada ${ }^{45}$ & & & & & Fruto $^{59}$ & \\
\hline $\begin{array}{l}\text { Pterodon pubescens } \\
\text { Benth }\end{array}$ & $\begin{array}{l}\text { Folha }^{45,52,547}- \\
14 \%\end{array}$ & $\begin{array}{l}15,6 \\
\text { folhas } \\
54\end{array}$ & $\begin{array}{l}\text { De pouco } \\
\text { pastada }^{45} \\
\text { a muito } \\
\text { apreciada } \\
\text { (para } P \text {. } \\
\text { emarginatus) }\end{array}$ & $\begin{array}{l}\text { Cerca }^{7}-100 \% \\
\text { Construção } \\
70 \% \\
\text { móveis,74-30\% } \\
\text { ponte }^{7,74}\end{array}$ & $0,1^{69}$ & 3,7 & $\begin{array}{l}\text { Longa } \\
\text { durabilidade } \\
7,74 \text { muito } \\
\text { resistente a } \\
\text { xilófagos } 63\end{array}$ & $\begin{array}{l}\text { Mel }^{81,66} \\
\text { Medicinal }^{97,99}\end{array}$ & $\begin{array}{l}\text { Grande } \\
\text { produtora de } \\
\text { néctar e pólen } \\
81\end{array}$ \\
\hline $\begin{array}{l}\text { Qualea grandiflora } \\
\text { Mart. }\end{array}$ & Folha ${ }^{39,45}-10 \%$ & $9,6^{54}$ & Pouco pastada ${ }^{45}$ & & & & & $\mathrm{Mel}^{81,86,92,66}$ & \\
\hline $\begin{array}{l}\text { Qualea parviflora } \\
\text { Mart. }\end{array}$ & Folha ${ }^{39,45}-15 \%$ & $7,5^{54}$ & Pouco pastada ${ }^{45,55}$ & & & & & $\mathrm{Mel}^{81,45,92,93}$ & $\begin{array}{l}\text { Produz pólen }{ }^{\mathrm{c}} \\
\text { e néctar }\end{array}$ \\
\hline Tabebuia aurea & $\begin{array}{l}\text { Flor }^{43,45,47}-36 \% \\
\text { Folha }^{55} 15 \%\end{array}$ & & Bem aceita ${ }^{55}$ & $\begin{array}{l}\text { Construção }{ }^{3,6,7,70}- \\
30 \%{ }^{d} \\
\text { Móveis }^{3,6-} 0 \%\end{array}$ & $0,8^{5,2}$ & 4 & $\begin{array}{l}\text { Muito } \\
\text { flexível }^{5,6,7} \\
\text { Não aguenta } \\
\text { contato com } \\
\text { terra }^{73}\end{array}$ & $\operatorname{Mel}^{81,92,1,66}$ & \\
\hline $\begin{array}{l}\text { Tachigali subvelutina } \\
\text { Tul }\end{array}$ & Folha $^{45,55}$ & $14,8^{54}$ & Pouco pastada ${ }^{45,55}$ & $\begin{array}{l}\text { Cerca }^{79}-30 \%{ }^{\mathrm{d}} \\
\text { construção }^{79}-20 \%\end{array}$ & $0,7^{78}$ & & $\begin{array}{l}\text { Baixa } \\
\text { resistência } \\
\text { ao } \\
\text { apodrecime } \\
\text { nto } 64\end{array}$ & $\mathrm{Mel}^{81,66}$ & \\
\hline Terminalia argentea & $\mathrm{Nao}^{39}$ & & & $\begin{array}{l}\text { Cerca }^{5,3,6,67}-60 \% \\
\text { Construção }^{67}-10 \%\end{array}$ & $0,7^{69}$ & 3 & $\begin{array}{l}\text { Média a boa } \\
\text { durabilidade } \\
\text { natural }^{5,3,1}\end{array}$ & $\operatorname{Mel}^{81,86,48,1}$ & \\
\hline
\end{tabular}


Dentre as 23 espécies estudadas, considerando as classificações mais frequentes, encontrou-se 14 espécies decíduas, 4 semi-decíduas e 5 sempre verdes (tabela 2). No período seco, $P$. reticulata, $T$. aurea e A. fraxinifolium apresentaram os maiores percentuais de RFA em relação aos valores de pleno sol (figura 4). Essas espécies são decíduas e no momento das medições estavam praticamente sem folhas. No período chuvoso, as espécies com copas mais ralas foram M. opacum, A. fraxinifolium e P.reticulata (figura 4). As espécies que tiveram copas mais densas, ou seja, menor porcentagem de RFA, foram $C$. langsdorffi; $L$. divaricata e $C$. americana no período seco, e E. dysenterica, $C$. langsdorffi e $D$. alata no período chuvoso.

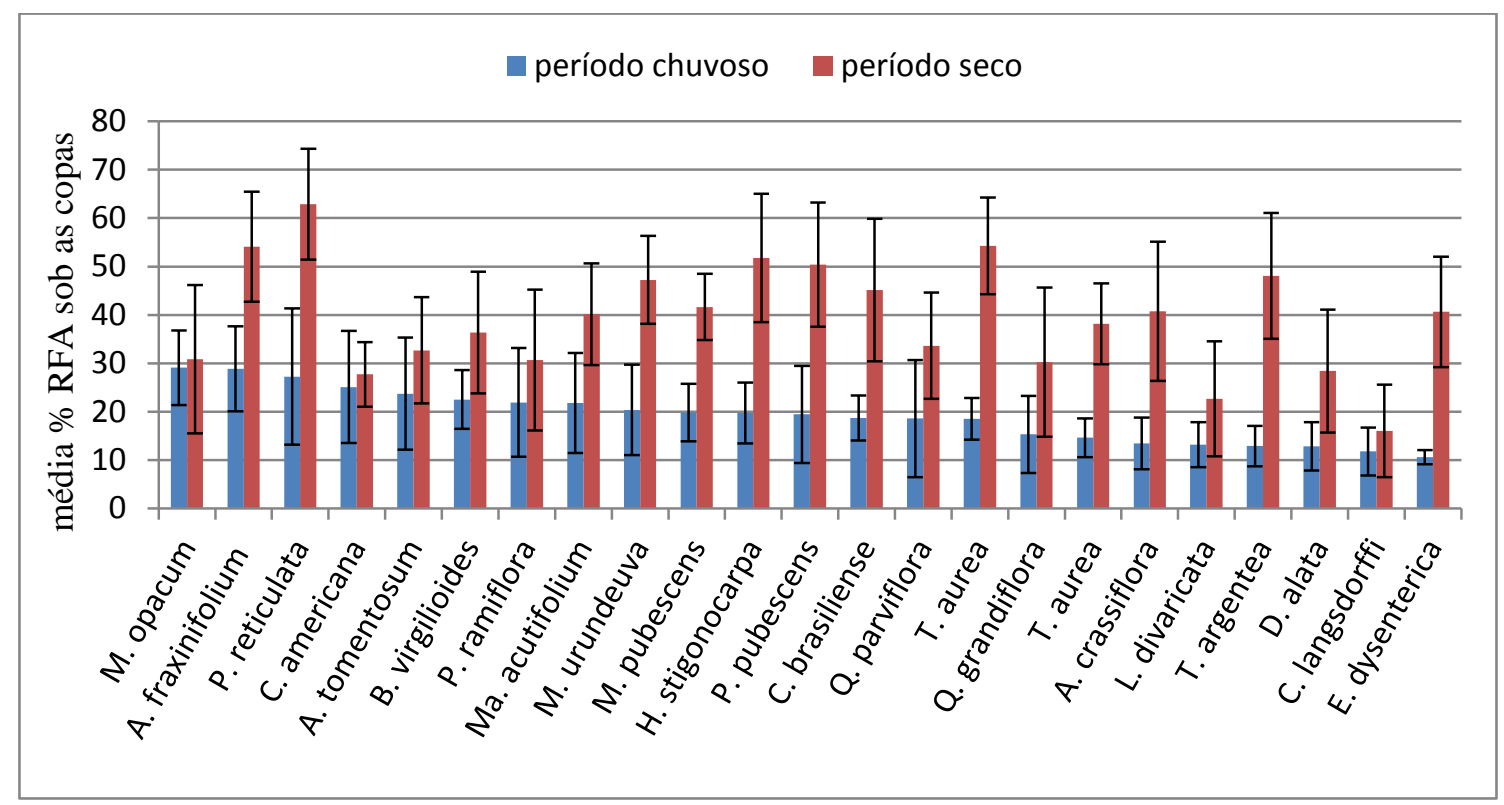

Figura 4 - Percentual médio da radiação fotossinteticamente ativa (\% RFA), durante o período chuvoso e seco, sob a copa de 23 espécies nativas do cerrado selecionadas para caracterização do potencial para arborizar pastagens. Colunas mostram média e barras mostram o erro padrão

\section{Associações simbióticas}

Das 23 espécies estudadas, oito $(39,1 \%)$ são da família Fabaceae, constituindose a família com maior número de espécies. A simbiose entre as bactérias que formam nódulos nas raízes capazes de fixar nitrogênio ocorrem nas três subfamílias. Porém muitas destas espécies não possuem esta capacidade (Tabela 2). Das oito espécies leguminosas, quatro (P. reticulata, B. virgilioides, T. subvelutina e M. acutifolium) apresentam estudos que confirmam sua capacidade de fixar nitrogênio, elas se associam ao Rhyzobium, sendo que a primeira forma nódulos do tipo muconóides e a segunda 
crotalóides. Para M. opacum não existem informações a esse respeito. Entretanto, de 20 espécies analisadas de Machaerium, 16 apresentaram nodulação (FARIA et al., 1989). A espécie $C$. langsdorffii, embora não nodule, associa-se ao Rhyzobium (CARVALHO, 2003). Foram encontradas informações acerca da associação com micorrizas para 16 espécies dentre as 23 aqui estudadas, sendo que 14 apresentam esta associação simbiótica e para duas espécies ( $M$. acutufolium, $Q$. grandiflora) houve divergências nas referencias consultadas (tabela 2).

\section{Cobertura do solo por capim}

As diferentes características das árvores estudadas podem interferir na produção de capim sob suas copas, constituindo-se uma variável de grande interesse para SSP. D. alata teve significativamente menos capim sob a copa das árvores, enquanto $B$. virgilioidese e $M$. acutifolum, tiveram maior cobertura de capim sob suas copas. As demais espécies não tiveram diferença entre a cobertura de capim dentro e fora de suas copas (figura 5).

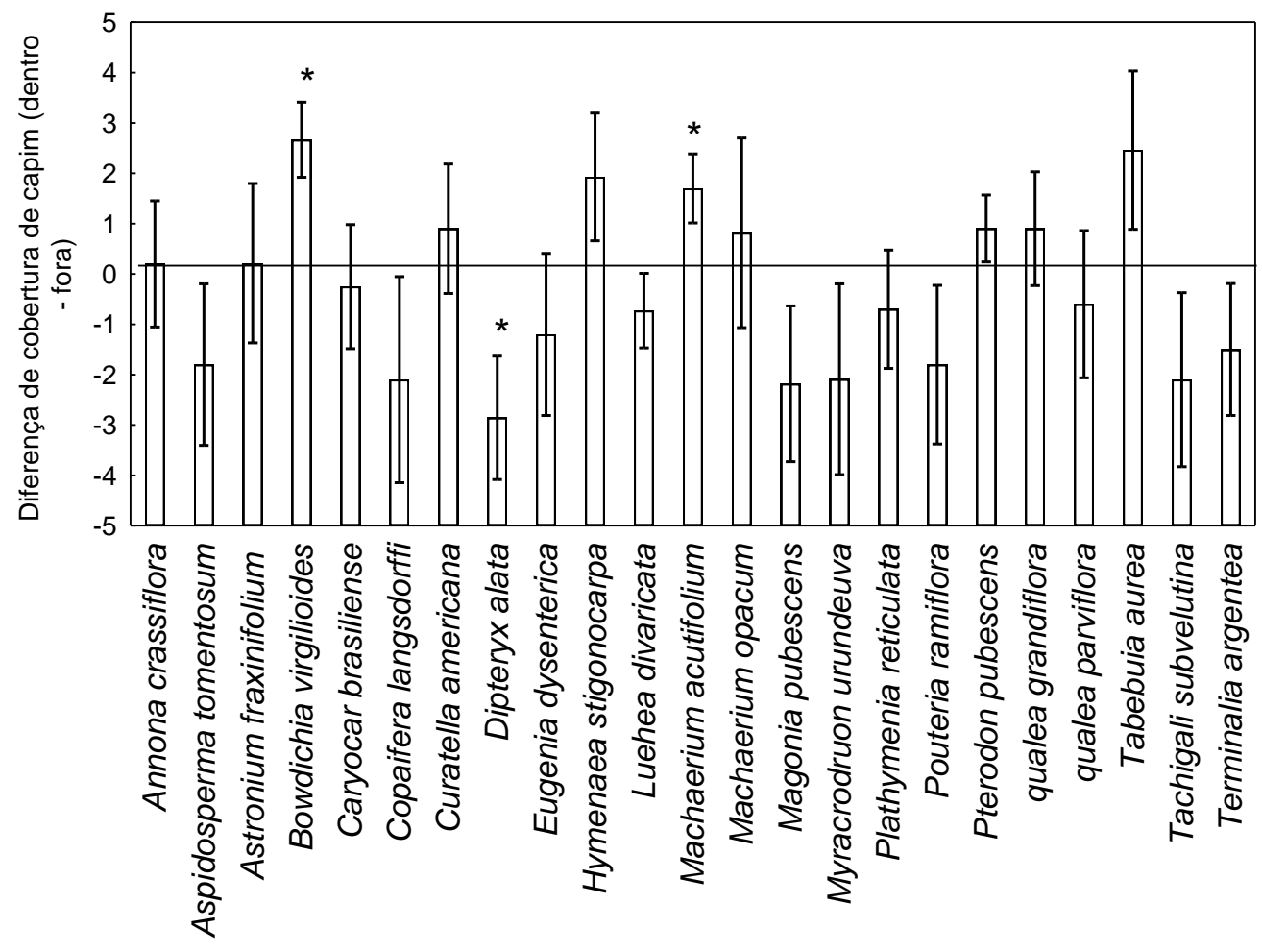

Figura 5: Diferença da cobertura do solo por capim dentro e fora da área de influencia da copa das árvores medidos entre os meses de junho a setembro, considerando 20 pontos para cada individuo, com dez repetições. Análises teste t pareado para cada espécie. Apenas as espécies com asterisco diferiram significativamente 


\section{Potencial de Influenciar diretamente os animais}

\section{Fornecimento de forragem}

Dentre as espécies estudadas, várias foram citadas pelos pecuaristas por fornecerem alimento ao gado (Tabela 2). A maioria das espécies é relatada como forrageira, seja pelos entrevistados, seja pela escassa literatura acerca do assunto. As árvores mais citadas pelos pecuaristas foram os frutos de D. alata (72\%) e E. dysenterica (60 \%). Em relação às folhas, em geral, foram citadas em baixo percentual, sempre por menos de $20 \%$ dos entrevistados, exceto as folhas de D. alata, mencionadas por $36 \%$ dos pecuaristas. Todavia, 31\% dos entrevistados admitem que o gado consome grande diversidade de folhas, mas não se atentaram à preferência por espécies. Encontrou-se bibliografia para todas as espécies citadas como forrageiras pelos entrevistados, exceto para o fruto de A. crassiflora, mencionado por 7\% dos pecuaristas. O nível de proteína relatado na literatura para as espécies estudadas variou bastante, sendo maior para as leguminosas e para o $M$. urundeuva, que apresentou o maior percentual proteico (18 a 20\%) (NASCIMENTO, 2008; CONCEIÇÃO, 2012).

\section{Efeitos indesejáveis das plantas aos animais}

Dentre os entrevistados, 33\% citaram não haver árvores que causem problemas ao gado, $11 \%$ mencionaram ao menos uma espécie, mas esclarece que nunca teve problema com nenhuma, apenas ouviu dizer. O fruto de $E$. dysenterica foi citado por $26 \%$ dos entrevistados por causar algum tipo de problema, como aborto (17\%), desinteira (25\%), emagrecimento (25\%), e “azedar" o leite mais rápido (33\%). Entretanto, vários dos agricultores comentaram que este efeito prejudicial só ocorre se o animal ingerir uma grande quantidade do fruto. A flor de pequi foi mencionada por $11 \%$ dos pecuaristas por causar emagrecimento no gado, pois devido sua alta palatabilidade o animal fica muito tempo embaixo da árvore aguardando a queda da flor. Apenas um agricultor $(2,5 \%)$ citou o fruto do baru e um outro a semente do tingui como indesejáveis ao gado (5\%). Outras espécies muito mencionadas (frutos de Enterolobium ssp, 38\%; de Dimorphandra mollis, 20\%; de Buchenavia tomentosa, 11\%) não estão entre as aqui estudadas.

$\mathrm{Na}$ literatura foi encontrado apenas um comentário sobre a toxidez dos frutos

de E. dysenterica. Ela foi responsabilizada por produtores como causadora de 
intoxicação em ruminantes, provavelmente por causar acidose ruminal quando os frutos são ingeridos em grandes quantidades, assim como outras frutas (BEZERRA et al., 2012). Embora os pecuaristas não tenham relatado problemas com D. alata e C. brasiliense, há relato na literatura de que os frutos de D. alata podem causar lesões na parede do rúmen e o caroço (endocarpo) de C. brasiliense possuem pequenos espinhos que podem provocar ferimentos na boca e órgãos anexos (AFONSO E POTT, 2001). Foi encontrada uma citação sobre a toxidez de $M$. pubescens para o gado, devido a presença de saponinas encontradas nas sementes e em menor quantidade nas folhas, porém, não foram apresentados dados experimentais sobre sua toxidez (ALMEIDA, 1998).

Embora pouco relatado na literatura, folhas de Pterodon emarginatus podem ser tóxicas para o gado (CRUZ et al., 2012). Esta espécie é frequente no Cerrado e tem aspecto parecido com sua congênere aqui estudada, Pterodon pubescens, ambas conhecidas popularmente como sucupira branca (SILVA JUNIOR, 2010). Ocorreram três surtos de intoxicação, supostamente causado por Pterodon emarginatus, no período de seca, em pastagens dos estados Mata Grosso e Mato Grosso do Sul, após consumo excessivo de suas folhas de árvores e galhos caídos (CRUZ et al., 2012). Após tais relatos, reproduziu-se a intoxicação com administração de folhas de $P$. emarginatus, e verificou-se por meio de dados epidemiológicos e sinais clínicos a toxidez desta espécie, principalmente ao fígado, podendo levar a morte dos animais (CRUZ et al., 2012). Entretanto, esta espécie não foi citada entre os pecuaristas entrevistados mesmo sendo uma das espécies mais frequentes nas pastagens estudadas.

\section{Geração de produtos madeireiros}

Diversas espécies do cerrado contidas nas pastagens possuem usos madeireiros, algumas delas geram matéria prima bastante valorizada pelos pecuaristas para estacas e cercas, construções e móveis (tabela 2). Pode-se perceber que o uso da madeira mais citado pelos pecuaristas foi para fabricação de cerca. Houve unanimidade em reconhecer o potencial para esta finalidade das espécies D. alata, M. urundeuva, P. pubescens e P. reticulata. Frequentemente, foi comentado que a aroeira seria a melhor dentre todas as espécies existentes. Também foi muito mencionado $(80 \%)$ o uso de $B$. virgilioides e M. opacum para fabricação de móveis. As citações dos entrevistados, de forma geral, estão em concordância com as referencias pesquisadas, porém o uso de $T$. argentea e $M$. acutifolium para confecção de estacas para cercas não foi encontrada na 
literatura, por outro lado, outras espécies com usos reconhecidos não foram citadas pelos pecuaristas. A maior altura do fuste foi de $M$. urundeuva, mediana de 4,6 m, seguida por $T$. aurea, e $C$. langsdorffii, ambas com 4,2 m. No outro extremo, $Q$. parviflora, Q. grandiflora, tiveram a menor altura do fuste com valor de 1,9 m (Tabela 2).

\section{Geração de produtos não madeireiros}

A possibilidade de uso de produtos não madeireiros das árvores nativas nas pastagens é uma vantagem dos SSPs. Exemplos desses produtos são frutos, medicamentos e exploração apícola. Os pecuaristas declararam consumir cinco espécies frutíferas dentre as 23 espécies estudadas (tabela 2). Dentre as frutíferas utilizadas, três delas, pequi (23\%), baru (13\%) e araticum (13\%), chegam a ser comercializadas por parte dos entrevistados ou, por terceiros que entram nas propriedades para colher tais frutas como o pequi (17\%). A maioria (87\%) das espécies estudadas apresenta potencial apícola (tabela 2).

\section{DISCUSSÃO}

\section{Influencia das Árvores na Pastagem}

\section{- $\quad$ Arquitetura da copa das árvores}

O capim sob copas de árvores em regiões de savana podem ter produção de biomassa maior (SOUSA, 2010), menor (MORDELET e MENAUT, 1995) ou semelhante (OLIVEIRA et al., 2005; LUDWIG et al., 2004) a áreas vizinhas sem árvores. Esta variação está relacionada a fatores ambientais como a precipitação da região (DOHN et al., 2013). As árvores influenciam positivamente o capim sob elas na medida em que aumentam a fertilidade e umidade do solo neste micro-ambiente, porém podem também influenciar negativamente por diminuir a radiação solar disponível, o efeito líquido será influenciado de acordo com os recursos mais limitantes, ou seja, em locais mais áridos e de solos pobres as árvores tendem a aumentar a produção de capim e em locais mais úmidos elas tendem a diminuir (DOHN et al., 2013; BLASER et al., 2013; MOUSTAKAS et al., 2013) . Mas estas variáveis não explicam totalmente os resultados, outros fatores correlacionados são características das árvores, como a 
capacidade de fixar nitrogênio e sua arquitetura (MAESTRE et al., 2009; BLASER et al., 2013).

A arquitetura das árvores, como a área e formato da copa, a altura total e da base da copa, RFA sob a árvore alteram consideravelmente o microclima para os animais, a quantidade de luz disponível e o potencial de evapotranspiração para as gramíneas (CARVALHO, 2002; CARON et al., 2012; SILVA, 2006). Poucos estudos abordam a influencia da altura das árvores no sombreamento e produção de capim (MOUSTAKAS et al., 2013). Existem orientações de que árvores altas são as mais indicadas para SSP, porém, raramente especifica-se a faixa de altura ideal reportando-se a experimentos científico (ANDRADE, 2012; CARVALHO, 1998; 2001; PORFIRIODA-SILVA, 2015). Na savana africana encontrou que a produção de matéria seca de seis capins nativos foi maior sob a copa das árvores com mais de $7 \mathrm{~m}$ de altura (MUOGHALU, 1995). No Brasil 7 metros também é citado como a altura mínima ideal (PORFIRIO da SILVA, 2015). As espécies aqui estudadas tiveram mediana superior a 7 metros, exceto $E$. desinterica $(6,7 \mathrm{~m})$, mas $30 \%$ apresentaram valores entre 7 e $8 \mathrm{~m}$. No bioma Amazônico, árvores consideradas altas, portanto ideais para SSPs, são as que possuem a partir de $15 \mathrm{~m}$ (ANDRADE et al., 2012). Em experimento realizado em 4 localidades da savana africana com precipitação média anual variando de 496 a 737 mm, a altura (mediana > 4,5 e < que 6 m) e diâmetro da copa das árvores influenciou positivamente a produção de biomassa do capim abaixo dela em três localidades e na outra localidade não houve correlação (MOUSTAKAS et al., 2013). Neste estudo a altura das árvores explicou em partes (até $21 \%$ ) a variação da produção de biomassa das gramíneas, porém isto precisa ser melhor investigado isolando outras variáveis ambientais como a precipitação, diferenças ao longo do tempo decorrentes de variações sazonais ou pressão de pastejo, diferenças entre espécies (MOUSTAKAS et al., 2013).

Copas baixas atrapalham a ventilação, logo a dissipação do calor dos bovinos (MARTIN, 2002), dificultam a secagem do solo no período chuvoso, que pode formar barro e constituir ambiente propício para bernes e doenças nos animais (FRANKE, 2001); além de diminuírem a radiação solar sob a copa (CARVALHO et al., 2001; 2002). Em estudo de meta- analise que abrangeu 36 pesquisas em um gradiente de precipitação, as árvores com copas próximas ao solo, diminuíram a produtividade do capim sob elas comparativamente a áreas sem árvores, mesmo em locais áridos (BLASER et al., 2013) Este autor fala da necessidade de mais estudos para determinar 
a altura da base da copa a partir da qual as árvores passam de competidores para facilitadores. A espécie do cerado que apresentou copa mais baixa, Q. grandiflora, com mediana de 1,6 metros, seria considerada copa alta de acordo com o critério adotado por Blaser (2013), que neste caso, apresentaram maior biomassa de capim sob as árvores do que longe delas. A altura média da base da copa de 2,7 m encontrada na presente pesquisa dificulta a passagem de tratores sob a árvore, sendo a altura mínima para não atrapalhar este procedimento de 3,5 m (PORFIRIO DA SILVA, 2015). As únicas espécies que apresentaram valor superior a 3,5 m foram Myracrodruon urundeuva e Bowdichia virgilioides. Entretanto, estas copas podem ser manejadas com facilidade por meio da poda dos galhos inferiores, prática já realizada por alguns dos entrevistados (capítulo 2). Apesar das copas das espécies avaliadas serem baixas para SSP comparativamente às espécies de ambientes florestais, muitas delas são também estreitas e pouco densas, portanto, tendem a permitir a entrada de luminosidade e circulação do vento.

Nas recomendações gerais de características desejáveis das árvores para SSP, poucas vezes há citações sobre o diâmetro ou área da copa (SILVA, 2006; SANFORD et al. 1982). Na savana africana, a produção de biomassa de gramíneas não diferiu significativamente em área aberta e sob copas de árvores pequenas $\left(12 \mathrm{~m}^{2}\right)$, médias (77 $\mathrm{m}^{2)}$ e grandes $\left(286 \mathrm{~m}^{2}\right)$ de Acacia tortilis. Neste trabalho, concluiu-se que sob a copa das árvores os solos são mais férteis, entretanto, há maior competição por água o que não permite maior produção de biomassa das gramíneas como ocorreu sob árvores mortas da mesma espécie (LUDWIG et al., 2004). Em outro trabalho, também na savana africana a produtividade de gramíneas (predomínio de Panicum maximum Jacq) sob diferentes dimensões de copas de árvores de Colophospermum mopane, mostrou maior produtividade de massa seca sob copas médias (3 a $6 \mathrm{~m}$ de diâmetro) e grandes (maior que $6 \mathrm{~m}$ ), comparativamente as copas pequenas (entre 2 e $3 \mathrm{~m}$ de diâmetro) e observou-se também maior infiltração de água no solo sob copas grandes (MLAMBO et al., 2005).

Característica marcante da vegetação lenhosa do cerrado é a ocorrência de diferentes grupos fenológicos em relação à produção e queda de folhas (FRANCO et al. 2005; LENZA \& KLINK, 2006). Pode-se observar uma grande variação de RFA entre os períodos seco e chuvoso, especialmente para as 14 espécies decíduas, mesmo que alguns indivíduos não estivessem em seu maior grau de deciduidade no momento das 
medições. As espécies de árvores com copas ralas ou pouco densas são ideias para sombrear pastagens por permitir o bom desenvolvimento do capim (CARVALHO, 2002; PORFÍRIO, 2015; ANDRADE et al., 2012; OLIVEIRA et al., 2003). Contudo, os animais preferem árvores com copas densas e altas (LEME et al, 2005; BENNETT et al., 1985) já que copas ralas, como Leucaena leucocephala, podem apresentar parâmetros de conforto animal inferiores a copas mais densas, como Terminalia catappa (chapéu de coro) e Melia azedarache (santa barbára) e com maior altura como Bambusa vulgaris (bambu) (GUISELINI et al., 1999). Árvores de 51 espécies da Amazônia foram categorizadas segundo a densidade das copas por análise visual e posteriormente confirmaram-se estas categorias com as medidas de RFA (\%), com média de 9\%; 29\%, 36\% e 49\% para copas muito densas, densas, pouco densas e ralas, respectivamente (ANDRADE et al., 2012). Das espécies de cerrado estudadas, $70 \%$ no período seco e $26 \%$ no período chuvoso tiveram copas correspondentes a ralas ou pouco densas de acordo com a classificação de Andrade et al. (2012). Estes valores devem ser ponderados com as outras características das árvores como a largura da copa, portanto, espécies com copa densa e estreita, limitam menos a penetração de luz do que árvores com copas densas e largas. A alta diversidade de espécies nas pastagens permite a presença de árvores sempre verdes que garante o sombreamento no auge da estação seca, época de maior deciduidade das árvores (GOUVEIA e FELFILI, 1998; LENZA e KLINK, 2006), portanto garantir um número mínimo destas espécies deve ser um critério na escolha das árvores na pastagem.

A única espécie que teve significativamente menos capim sob sua copa do que em área vizinha sem árvores foi $D$. alata. Sua copa é considerada densa durante todo ano, não é estreita (valores superiores á mediana), ela não fixa nitrogênio ao solo, portanto, estas características podem explicar tal resultado. Esta espécie apresenta vantagens como fruto muito forrageiro e a qualidade da madeira e representa a quarta espécie com maior densidade nas pastagens. Por outro lado, B. virgilioidese e $M$. acutifolum, tiveram maior cobertura de capim sob suas copas (figura 5). Ambas espécies são fixadoras de nitrogênio, possuem copas pouco densa (valores de \%RFA inferiores à mediana) estreitas (valores inferiores a mediana) e base elevada (valores superiores à mediana), todas estas características são desejáveis para arborização de pastagens. 


\section{- Densidade de árvores e sombreamento das pastagens}

Definir a quantidade de árvores no pasto, o percentual de cobertura arbórea ou o nível total de sombreamento estão entre as principais dúvidas dos pecuaristas (ANDRADE et al, 2012). Existe grande amplitude de valores indicados, para o número de árvores dispersas por hectare pode variar entre 30 e 160, pois depende da arquitetura das árvores, tolerância ao sombreamento das espécies de capim e do déficit hídrico e insolação na pastagem (MURGETIO, 2004; MARTIN, 2002; SOUSA et al., 2010; PACIULLO et al., 2011). O nível ideal de cobertura de copas varia de 15 a 50\% da área do pasto (CARVALHO et al., 2002; MARTIN, 2002; MIMENZA, 2007). Outros trabalhos se referem ao nível de sombreamento ideal de 20 a 70\% (MARTUSCELLO et al., 2009; CARVALHO et al. 2002; CASASOLA, 2005; SOUSA et al., 2010; SAMARAKOON et al., 1990). A densidade de árvores na pastagem também pode variar com sua distribuição espacial, pois a arquitetura das copas pode mudar segundo maior ou menor competição por luz com as árvores vizinha, de tal modo que o número de árvores pode ser maior em SSPs em linhas ou faixas do que com árvores dispersas (CASTRO e PACIULLO, 2006; CARVALHO, 2002). Árvores com copa rala, estreita e base alta podem ter maior densidade no pasto e isto tende a ser vantajoso em termos econômicos, por exemplo, se utilizar espécies madeireiras. No cerrado lato senso as árvores nativas são de menor porte comparativamente a ambientes florestais, portanto, a densidade de indivíduos lenhosos tende a ser maior. Por exemplo, 240 árvores/ha no município de Goiás-GO, aumentou comprovadamente o conforto térmico dos animais embora a produção de leite de gado mestiço tenha sido a mesma comparativamente a área em pleno sol ou com sobra artificial (FERREIRA, 2010).

O nível de sombreamento benéfico para os animais pode não ser para as gramíneas conforme experimento no sul de Minas Gerais (PACIULLO, 2011), portanto análises integradas são importantes. Trabalhos em áreas tropicais com forte sazonalidade mostram que diferentes níveis de sombreamento de pastagens trazem melhorias fisiológicas e comportamentais ao gado e podem aumentar sua produtividade, mas não medem a influencia sobre o capim (FERREIRA, 2010; YAMAMOTO et al., 2007). Por outro lado, são frequentes trabalhos, inclusive no Cerrado, que mostram a influência do grau de sombreamento na produtividade do pasto mas não averiguam os efeitos sobre os animais (SOUSA, 2010; OLIVEIRA et al., 2005) Embora ainda faltem pesquisas mais integradas, existem evidencias que, em áreas tropicais com sazonalidade 
climática, para níveis de sombreamento moderado, por volta de $20 \%$ a $50 \%$, há benefícios produtivos aos animais em consequência do aumento do seu conforto térmico, somado, algumas vezes, a maior produtividade e/ou qualidade da forragem, principalmente no período seco (YAMAMOTO et al., 2007; BETANCOURT et al. 2003; RESTREPO, 2002; SOUSA, 2010; PACIULLO et al., 2008; DA SILVA, 2008;).

\section{- $\quad$ Fixação de N e associação com micorrizas}

As gramíneas beneficiam-se do $\mathrm{N}_{2}$ fixado por plantas leguminosas, seja pela excreção direta de compostos nitrogenados pelas raízes, seja pela decomposição dos nódulos das raízes e das folhas (BRONSTEIN, 1984; WEARNER, 1988). Estudos demonstram que a biomassa de árvores leguminosas aumenta a disponibilidade de nitrogênio no solo para as forrageiras herbáceas e melhora a qualidade e a quantidade da forragem produzida (CASTRO et al., 2009; PACIULLO et al., 2008; ANDRADE et al., 2002;). Essa característica é altamente vantajosa para a recuperação e melhoria do solo em áreas de SSP, em regiões tropicais esse nutriente é o que mais afeta a produtividade das pastagens e sua degradação (BODDEY et al., 2004). A associação das plantas às micorrizas arbusculares é também benéfica à fixação biológica de $\mathrm{N}$ pelas leguminosas (CARDOSO, 1985; JESUS, 2005). A associação simbiótica das plantas com fungos micorrízicos arbusculares (FMA) é caracterizada pelo movimento bidirecional, nutrientes são absorvidos pelos fungos e transferidos à planta e essa transfere fotossintatos aos fungos (ORTAS \& VARMA, 2007). Os benefícios dos FMA não se limitam às plantas em associação, estende-se a comunidade vegetal e ao ambiente, melhora a fertilidade, a estrutura e a retenção de umidade no solo (AUGÉ et al., 2001). Portanto, espécies arbóreas com associação micorrízica são importantes nos sistemas silvipastoris, pois promovem o enriquecimento das camadas superficiais do solo, por meio da ciclagem de nutrientes e podem aumentar a eficiência das gramíneas no uso de eventuais fertilizações, principalmente fosfatadas. (DA SILVA PORFIRIO, 2015). Para as espécies de cerrado em SSPs, é necessário avaliar o potencial de nodulação e de associação com micorrizas das espécies em condições locais e os efeitos de cada espécie nosolo e no capim, em termos de produtividade e qualidade nutricional.

\section{Árvores forrageiras e as que podem prejudiciais os animais}

Os resultados da presente pesquisa sugerem potencial forrageiro de diversas árvores nativas. A forragem proveniente das árvores e de seus regenerantes são 
relevantes para manter o gado, principalmente durante o período seco, segundo declararam $65 \%$ dos entrevistados. A maioria dos experimentos no Cerrado foram realizados a partir de fistula esofágica para conhecer a dieta alimentar do gado, a maioria das vezes em pastagem nativas, com posterior análise do valor nutricional das plantas consumidas, e reiteram a afirmação dos entrevistados citada acima (MACEDO et al., 1978; SILVA, 1986; SANTOS, 2002). Publicações sobre caracterização de árvores que ocorrem no cerrado citam o valor forrageiro de algumas espécies, baseandose em conhecimento popular ou nas referencias acima (ALMEIDA et al., 1998; SILVAJUNIOR, 2005; IBGE, 2002; CARVALHO, 2008; POTT e POTT, 1994). Existem estudos sobre o uso forrageiro de árvores em outros Biomas como Caatinga (MAIA, 2004; NASCIMENTO, 2008) e Pantanal (POTT e POTT, 1987; 2003; SANTOS et al. 2003; POTT, 1998), com um enfoque similar, ressaltando a importância e potencial destes frutos e folhas para complementar a alimentação dos animais, especialmente no período de estiagem, inclusive com citações de espécies que ocorrem no Cerrado (tabela $2)$.

Durante o período seco diversas árvores, especialmente espécies leguminosas, apresentam maior porcentagem de proteína e digestibilidade da matéria seca comparadas ao capim (KU, 2005; SOLORIO et al., 2000; GUIMARÃES FILHO e SOARES, 1997). As gramíneas representam a principal fonte de alimentos para bovinos (BÓO et al., 1993; LIMA et al., 1998; SANTOS et al., 2002), embora esses animais apreciem maior variedade em sua dieta (SANTOS et al., 2002; USDA, 2005). A diversidade de forragens representa uma dieta mais balanceada, otimização do forrageamento e do tempo de ruminação e manutenção de microflora diversificada (SANTOS et al., 2003; SANCHEZ, 2001). Diversificar forrageiras arbóreas em pastagens demanda estudos sobre as espécies mais palatáveis e nutritivas ao gado nativas de cada região, para que possam ser cultivadas por meio de práticas de manejo. A capacidade de diversas espécies do cerrado de rebrotar após o corte ou danos às raízes (RIZZINI e HERINGER, 1966; FERREIRA et al., 2015; APEZZATO DA GLÓRIA, 2000; VIEIRA et al., 2006;) pode ser uma vantagem para o manejo visando o cultivo. Por exemplo, a aroeira (Myracrodruon urundeuva), considerada em diferentes regiões do bioma Cerrado como espécie difícil de controlar por sua alta capacidade de regeneração (POTT et al., 2006; VIEIRA et al., 2006), pode ser mantida em porte arbustivo por meio de constantes podas, permitindo o direto ramoneio dos animais, o 
que representa uma grande vantagem devido ao elevado valor proteico de suas folhas (MAIA, 2004, NASCIMENTO, 2008). O baru já possui seu valor forrageiro conhecido, foi a espécie forrageira mais citada entre os entrevistados. Além do seu fruto ser consumido pelo gado, suas folhas parecem ter grande potencial forrageiro por serem bem aceitas, aguentarem bem o ramoneio e serem bastante nutritivas (POTT, 1988; MELOTTO et al., 2012).

Algumas espécies, embora forrageiras, podem ser prejudiciais aos animais. Identificar estas espécies é importante, porém também é preciso compreender a atuação de cada uma delas e conhecer a dose em que determinada espécie torna-se tóxica. Por exemplo, no caso de Pterodon emarginatus, os casos de consumo das folhas se deram em situações especiais, como a derrubada da árvore e forte ventania com queda de galhos, o que possibilitou aos animais acesso a grande quantidade de folhas (CRUZ et al., 2012). Assim como neste trabalho, em outros pesquisados (TOKARNIA et al., 2000; 2002; AFONSO e POTT, 2001; MELLO et al., 2010; POTT, 1982.) não encontrou-se relatos sobre a intoxicação por essa espécie, mesmo ela sendo muito frequente nas pastagens. Os escassos relatos na literatura sobre efeitos indesejáveis de espécies arbóreas importantes para a pecuária, como é o caso dos possíveis danos mecânicos do pequi e do baru, e efeitos tóxicos do tingui e da sucupira branca, são exemplos de que pesquisas nesta área precisam ser aprofundadas e disponíveis aos agricultores para que eles possam aproveitar os múltiplos usos das espécies e realizar o manejo correto em relação à toxidez, evitando a frequente ação de eliminar tais árvores dos pastos.

\section{Produtos madeireiros e não-madeireiros}

A utilização das árvores nas pastagens para fins madeireiros, principalmente de caráter eventual e doméstico, é uma das principais motivações dos pecuaristas para mantê-las (capítulo 2). A maior porcentagem de citações para o uso da madeira para cerca sugere que este produto é bastante valorizado pelos agricultores. Em sistemas de pastagens na região do Cerrado, são encontrados $842 \mathrm{~m}$ de cerca por ha, e o uso de cercas vivas ou postes de cimento é pouco frequente no Brasil (HERMUCHE et al., 2013, NASCIMENTO, 2007). Por isso o uso das espécies arbóreas para instalação de cercas mortas tem diminuído a cobertura vegetal das propriedades (HERMUCHE et al., 2013; NASCIMENTO, 2007) e ao se tornarem escassas esta matéria prima tem sido 
substituída de forma crescente por estacas de eucalipto tratado (GERALDO, 2008; VIDA et al., 2015). É importante investir esforços para orientar o correto manejo dessas espécies na pastagem para possibilitar o atendimento dessa demanda sem prejuízo dos outros usos das árvores nas pastagens.

O consumo dos frutos do cerrado pode estar ligado à questão cultural, ou seja, pessoas que conviveram por longos períodos em contato com este ambiente, tendem a apreciar seus frutos. Durante as entrevistas $20 \%$ dos entrevistados comentaram, embora esta não fosse uma pergunta da entrevista, que não tem costume de comer frutos do cerrado pois em sua região de origem não haviam estas espécies. Os frutos do cerrado possuem grande valor nutritivo (ALMEIDA et. al., 1998; 2008) e sua utilização e comercialização pode ser ampliada por meio de políticas públicas. O caso do Programa Nacional de Alimentação Escolar - PNAE, que compra no mínimo 30\% de produtos da agricultura familiar para a merenda escolar, é um exemplo que vem contribuindo para ampliação do consumo destes frutos. Essas frutíferas também vêm sendo utilizadas em um mercado promissor de comidas gourmet (MEDEIROS, 2011; DAMASCENO JUNIOR e SOUZA, 2010) A valorização destes produtos no mercado pode representar um estímulo adicional à manutenção e enriquecimento destas árvores nos pastos.

Diferentes árvores nativas localizadas nas pastagens também podem ser úteis para atrair polinizadores, dentre eles as abelhas e assim gerar renda por meio da exploração apícola. O pólen e o néctar constituem a única fonte de alimento das abelhas, sendo que o pólen é fonte concentrada de proteína e o néctar importante fornecedor de energia (DE ALMEIDA et al., 2003). O valor de uma planta apícola é medido pela concentração de açúcares em seu néctar (variações de 2 a 77\%), pelo valor proteico do pólen (variações de 10 a 36\%) e pela quantidade produzida de néctar e pólen (DE ALMEIDA et al., 2003). A diversidade de espécies representa potencial para oferecer sucessivas florações ao longo do ano gerando alimento às abelhas em diferentes períodos (DE ALMEIDA, 2003). Existem indícios da compatibilidade entre as atividades econômicas de pecuária e apicultura, uma vez que apiários localizados próximos a pastagens com árvores nativas tiveram similaridade nas quantidades e tipos polínicos presentes no mel, com destaque para aroeira, comparativamente aos localizados em áreas de Cerrado nativo (DOS SANTOS, 2011). Há mercado promissor já que o consumo de produtos apícolas no Brasil ainda é baixo (SEBRAE, 2009), mas com indícios de aumento (BUAINAIN e BATALHA, 2007). A produção e 
lucratividade desse tipo de produto vêm crescendo, principalmente voltado para o mercado externo (SEBRAE, 2009). A região centro-oeste é responsável por apenas $4,4 \%$ da produção nacional, o que mostra como este setor no Cerrado ainda precisa ser desenvolvido (IBGE, 2012).

\section{CONSIDERAÇÕES FINAIS}

A caracterização das 23 espécies arbóreas nativas do cerrado pode subsidiar as decisões dos pecuaristas na escolha das árvores que desejam ter em suas pastagens. Preferi não ranquear as espécies, mas apenas gerar elementos que contribuam para que os próprios pecuaristas, junto aos assessores técnicos, analisem de acordo com suas preferencias, realidades e objetivos. É necessário ressaltar que as árvores citadas são apenas uma amostra dentre a grande diversidade de espécies nativas que podem compor sistemas silvipastoris. Em 47 pastagens do cerrado, encontramos 145 espécies de árvores dispersas (capítulo 2). Outros atributos ainda podem complementar este estudo, como a alelopatia entre as árvores e o capim, o ciclo de vida das espécies, a resistência ao vento. Em algumas situações os pecuaristas podem optar em plantar estas árvores, portanto informações sobre a germinação das sementes, a sobrevivência e o crescimento em campo por semeadura direta ou plantio de mudas, e a possibilidade de propagação vegetativa podem ser úteis.

Fica evidente o potencial das árvores nativas não apenas para sombrear os pastos, mas também para gerar uma diversidade de outras vantagens e produtos, constituindo-se em espécies multi-propósito. Os produtos provenientes destas espécies (madeira, lenha, forragem, frutos, medicamentos, mel) contribuem economicamente na renda familiar, seja por sua venda, seja por evitar gastos para estes fins. A possibilidade de diversificar as atividades no meio rural, principalmente com a utilização da mesma área produtiva e agregando renda, representa vantagem aos pecuaristas, sobretudo aos de maior vulnerabilidade econômica. 


\section{REFERENCIAS BIBLIOGRAFICAS}

APEZZATO DA GLÓRIA, B. Raízes gemíferas: Uma abordagem anatômica e ecológica. In: CAVALCANTE, T. B.; WALTER, B. M. T. (ORG) Tópicos atuais em botânica. Brasília: Sociedade Botânica do Brasil: Embrapa Recursos Genéticos e Biotecnologia, 2000, p.73-77.

AFONSO, E.; POTT, A. Plantas no pantanal tóxicas para bovinos. Campo Grande, MS: EMBRAPA/Gado de corte, 2001, 51p.

ALLEM, A. C. Estudos da biologia reprodutiva de duas espécies florestais (aroeira e gonçado-alves) da região do Cerrado. Brasília, DF: EMBRAPA-CENAGEN, 1991. 5p. (EMBRAPA-CENAGEN. Pesquisa em andamento, 2)

ALMEIDA, S. P. de.; et al. Cerrado: espécies vegetais úteis. EMBRAPA, DF, 1998, p. 464.

ALMEIDA, M. A. D. DE.; CARVALHO, C. M. S. Apicultura: uma oportunidade de negócio sustentável. SEBRAE, Salvador: SEBRAE Bahia, 2009, p.52.

ALMEIDA, S. P.; COSTA, T. S. A.; SILVA, J. A. Frutas nativas do Cerrado: caracterização físico-químico e fonte potencial de nutrientes . 2008, 1279p. in: SANO, S. M.; ALMEIDA, S. P.; RIBEIRO, J. F. (eds.). Cerrado: ecologia e flora. EMBRAPA Informação Tecnologia, Brasília-DF.

ALTIERI, M. Agroecologia: a dinâmica produtiva da agricultura sustentável. 5 ed. Porto Alegre: UFRGS, 2008. 120p.

ALTIERI, M. \& TOLEDO V.M.. The agroecological revolution of Latin America: rescuing nature, securing food sovereignity and empowering peasants. Journal of Peasant Studies, v. 38, n. 3, 2011

ANDRADE, C. M. S. Guia arbopasto: manual de identificação e seleção de espécies arbóreas para sistemas silvipastoris, Brasília, DF : Embrapa, 2012, 345p.

AUGÉ, R.M., et al. Moisture retention properties of a mycorrhizal soil. Plant and Soil, v. 230, p.87-97. 2001.

BALA, A.; et al. Nodulation of tree legumes and the ecology of their native rhizobial populations in tropical soils. Applied Soil Ecology, v.22, p.211- 223, 2003.

BARBERI, A.; et al. Nodulação em leguminosas florestais em viveiros no sul de minas gerais. CERNE, v.4, n.1, p.145-153. 1998. 
BARBOSA, R. R.; et al. Plantas tóxicas de interesse pecuário: importância e formas de estudo. Acta Veterinaria Brasílica, v.1, n.1, p.1-7. 2007.

BAREA, J. M.; AZCÓN-AGUILAR, C. Mycorrhizas and their significance in nodulating nitrogen-fixing plants. Advances in Agronomy, v. 36, p. 1-54. 1983.

BASTOS, E.; BRANDÃO, M.; FERREIRA, J. A. Inventário da flora apícola do Município de Bom Jesus do Amparo, Minas Gerais - II. Daphne, Belo Horizonte, v. 3, n. 4, p. 21-31, out. 1993.

BASTOS, E. M.; et al. Inventário da flora apícola do Cerrado no Estado de Minas Gerais: I. Município de Cardeal Mota. Daphne, Belo Horizonte, v. 8, n. 3, p. 44-50, jul, 1998.

BELSKY, A.J.; MWONGA, S. M.; DUXBURY, J. M.; Effects of widely spaced trees and livestock grazing on understory environments in tropical savannas. Agroforestry Systems, 1993, v.24 p.1-20.

BENNETT, I. L.; FINCH, V. A.; HOLMES, C. R. Time spend in shade and its relationship with physiological factors of thermoregulation in three breeds of cattle. Applied Animal Behaviour Science, Amsterdam, v. 13, p. 227-236, 1985.

BETANCOURT, K. et al. Efecto de la cobertura arbórea sobre el comportamiento animal en fincas ganaderas de doble propósito em Matiquas. Agroflorestería en las Américas, Matagalpa: Nicaragua, v. 10, p. 47-51, 2003

BLASER, W. J. et al. Facilitative or competitive effects of woody plants on understorey vegetation depend on $\mathrm{N}$-fixation, canopy shape and rainfall. Journal of Ecology, v. 101, p. 1598-1603, 2013

BODDEY, R. M. et al. Nitrogen Cycling in Brachiaria pastures: the Key to understanding the process of pasture decline. Agriculture Ecosystems e Environment. v.103, n. 2, p.389-403, 2004

BORCHERT, R. Responses of tropical trees to rainfall seasonality and its long-term changes. Climate Change, v.39, p.381-393. 1998.

BRAGA, R. Plantas do nordeste, especialmente do Ceará. Fortaleza: Depto. Nacional de Obras Contra as Secas, 1960. 540 p.

BRANDÃO, M.; FERREIRA, F. B. D. Flora apícola do Cerrado. Informe Agropecuário, Belo Horizonte, v.15, n. 168, p. 5-7, 1991. 
BRANDÃO, M.; GAVILANES, M. L.; ARAÚJO, M. G. de. Cobertura vegetal do Município de Prudente de Morais, MG. Daphne, Belho Horizonte, v. 6, n. 2, p. 40-58, abr. 1996.

BRASIL. Produção da pecuária municipal. Disponível em: <http://ibge.gov.br/Producao_Pecuaria/Producao_da_Pecuaria_Municipal/2012/ppm201 2.pdf $\geq$. Acesso em: 07 out 2014.

BRIDGEWATER S.; RATTER J. A.; RIBEIRO J. F. Biogeographic patterns, Betadiversity and dominance in the cerrado biome of Brazil. Biodiversity and Conservation, v. 13, n.12, p. 2295-2318. 2004.

BUAINAIN, A. M.; BATALHA, M. O. Cadeias produtivas de flores e mel. Brasília: MAPA. 2007

BULHÃO, C. F.; FIGUEIREDO. P. S. Fenologia de leguminosas arbóreas em uma área de cerrado marginal no nordeste do Maranhão Revista Brasil. Bot., v. 25, n.3, p.361369 , set. 2002

CALLAWAY, R. M.; NADKARNI, N. M.; MAHALL, B. E, Facilitation and interference of Quercus douglasii on understory productivity in Central California. Ecology. v. 72, p. 1484-1499, 1991.

CAMPOS FILHO, E. M.; SARTORELLI, P. A. R.; Guia de árvores com valor econômico. São Paulo: INPUT - AGROICONE. nov. 2015, v.1, p. 141.

CARDOSO, E. J. B. N. Efeito de micorriza vesículo-arbuscular e fosfato-de-rocha na simbiose Soja-Rhizobium. Revista Brasileira de Ciência do Solo, v. 9, p.125-130. 1985.

CARDOSO, P. Pantanal Brasil: um universo natural em suas mãos. Cuiabá, MS. 2008, $184 \mathrm{p}$.

CARON, B. O. et al. Interceptação da radiação luminosa pelo dossel de espécies florestais e sua relação com o manejo das plantas daninhas. Ciência Rural, vol. 42, n.1, p. 75-82, 2012.

CARVALHO, P. E. R. Espécies arbóreas brasileiras. Brasília, DF: Embrapa Informação Tecnológica; Colombo: Embrapa Florestas, 2003. v. 1.

CARVALHO, M. M. Recuperação de pastagens degradadas em áreas de relevo acidentado. In: DIAS, L. E.; MELO, J. W. V. (ed.) Recuperação de Áreas 
Degradadas. Viçosa: UFV, Departamento de Solos; Sociedade Brasileira de Recuperação de Áreas Degradadas, 1998. p. 149-161.

CARVAlHO, M. M.; XAVIER, D. F.; ALVIM, M. J. Características de algumas leguminosas arbóreas adequadas para a associação com pastagens. Juiz de Fora: Embrapa Gado de Leite, 2001. 24 p. (Circular Técnica, 64).

CARVALHO, M. M. et al. Estabelecimento de sistemas silvipastoris: ênfase em áreas montanhosas e solos de baixa fertilidade. Juiz de Fora: Embrapa Gado de Leite. 2002 (Circular Técnica, 68)

CARVALHO, P. E. R. Espécies arbóreas Brasileiras. EMBRAPA Informação Tecnologia: Brasília - DF, 2003, v. 1, p. 435.

CARVALHO, P. E. R. Espécies arbóreas Brasileiras. EMBRAPA Informação Tecnologia: Brasília - DF, 2006, v. 2, p. 435.

CARVALHO, P. E. R. Espécies arbóreas Brasileiras. EMBRAPA Informação Tecnologia: Brasília - DF, 2008, v. 3, p. 435.

CARVALHO, P. E. R. Espécies arbóreas Brasileiras. EMBRAPA Informação Tecnologia: Brasília - DF, 2010, v. 4, p. 435.

CARVALHO, P. E. R. Espécies arbóreas Brasileiras. EMBRAPA Informação Tecnologia: Brasília - DF, 2014, v. 5, p. 435.

CASTRO, C. R. T. et al. Características agronômicas, massa de forragem e valor nutritivo de Brachiaria decumbens em Sistema Silvipastoril. Pesquisa Florestal Brasileira, n. 60, p.19-25, 2009.

CASTRO, C. R. T; PACIULlO D. S. C. Boas práticas para a implantação de sistemas silvipastoris. Juiz de Fora: Embrapa Gado de Leite. 2006. (Comunicado Técnico, 50).

CEMIG. Guia ilustrado de plantas do Cerrado de Minas Gerais. Belo Horizonte: Empresa de Artes, 2001.

CRESTANA, C. de S. M. Biologia de polinização Copaifera langsdorffi Desf. (Leguminosae - caesalpinoideae), o “óleo-de-copaíba”. Revista do Instituto Florestal, São Paulo, v. 1, n. 1, p. 201-214, 1989. 
CONCEIÇÃO, G. M. da. Caracterização botânica e fitossociologia de uma área de cerrado, no Maranhão, sob pastejo por Bovinos. 2012. 113 f. Tese (doutorado em Zootecnia) - Faculdade de Ciências Agrárias e Veterinárias, UNESP, Jaboticabal, 2012

DALMOLIN, A. C. et al. Is the dry season an important driver of phenology and growth for two Brazilian savanna tree species with contrasting leaf habits? Plant Ecol v. 216, p.407-417, 2015

DAmASCEnO JUniOR, G. A.; DE SOUZA, P. R. (org). Sabores do Cerrado e Pantanal: receitas e boas práticas de aproveitamento. Campo Grande: UFMS, 2010, $141 \mathrm{p}$.

DA SILVA, L. L. M. G. Influência da Arborização de Pastagens no Sistema SoloPlanta-Animal. 2008. 77 f. Tese (Doutorado em Ciências) - Instituto de Agronomia, Universidade Federal Rural do Rio de Janeiro, Seropédia, 2008.

DE ALMEIDA, D. et al. Plantas visitadas por abelhas e polinização. Série Produtor Rural, Edição Especial. Piracicaba: ESALQ - Divisão de Biblioteca e Documentação, 2003. $40 \mathrm{p}$.

DOS SANTOS, M. F. Relação entre a diversidade polínica e a produção de mel de Apis melífera L. frente às atividades antrópicas no sudoeste de Mato Grosso. 2011. 111f. Dissertação (mestrado em Ciências Ambientais) - Universidade do Estado de Mato Grosso, Cáceres, MT, 2011

DURR, P. A; RANGEL J.. Enhanced forage production under Samanea saman in a subhumid tropical grassland. Agroforestry Systems, v. 54, p.99-102, 2002.

FERREIRA, L. C. B. Respostas fisiológicas e comportamentais de bovinos submetidos a diferentes ofertas de sombra, 2010. 89 f. Dissertação (mestrado). Universidade Federal de Santa Catarina, Florianópolis , 2010

FARIA, S.M.; et al. Occurrence of nodulation in the Leguminosae. New Phytologist, v.11 p.607-619. 1989.

FRANCO, A. C.; et al. Leaf functional traits of Neotropical savanna trees in relation to seasonal water deficit. Trees Structure and Function, v. 19, n. 3, p. 326-335, 2005

FRANKE, I. L. \& FURTADO, S. C. Sistemas silvipastoris: fundamentos e aplicabilidade. Rio Branco: Embrapa Acre; 2001: 51p. (Documentos, 74). 
GERALDO, F. C. Mourões para cercas: a renovação necessária. Revista da madeira, Curitiba, PR, n. 115, jul., 2008.

GUISELINI, C.; SILVA, I. J. O.; PIEDADE, S. M. Avaliacao da qualidade do sombreamento arboreo no meio rural. Rev. Brasileira de Engenharia Agrícola e Ambiental, v.3, n.3, p.380-384, 1999.

HARVEY, C. A. Windbreaks enhance seed dispersal into agricultural landscapes in Monteverde, Costa Rica. Ecol. Application, v.10, p.155-173, 2000.

HERINGER, E. P.. FERREIRA, M. B. Árvores úteis da região geo-econômica do DF: aroeira , gonçalo e gibatão, o gênero Astronium e sua importância florestal. Cerrado, Brasília, v.5, n22, p.24-33, 1973.

HUECK, K. Florestas da América do Sul. São Paulo: Polígono, 1972. 466 p. il.

IBGE. Árvores do Brasil Central: espécies da região geoeconômica de Brasília. Rio de Janeiro, 2002. v.1, p. 417.

JESUS, E. da C.; SCHIAVO, J. A.; FARIA, S. M. de. Dependência de micorrizas para a nodulação de leguminosas arbóreas tropicais. Rev. Árvore, v.29, n.4. jul/ago. 2005.

KABAKOFF, R.P.; CHAZDON, R.L. Effects of canopy species dominance on unerstory light availability in low, elevation secondary forest stands in Costa Rica. Trop. Ecol., v.12, p.779- 788, 1996.

KU J. Nutritive value of trees and shrubs for ruminants. In: Mosquera-Losada et al. (eds). Silvopastoralism and sustainable land management. CABI publishing. pp 83$86,2005$.

LEAL, I. R.; VICENTE, A.; TABARELLI, M. Herbivoria por caprinos na Caatinga da Região de Xingó: uma análise preliminar. In LEAL, I. R.; TABARELLI, M.; SILVA, J. M. C. da (Ed.). Ecologia e conservação da Caatinga. Recife: Universidade Federal de Pernambuco, 2003. p. 695-715.

LEME, et al. Comportamento de vacas mestiças holandês x zebu, em pastagem de Brachiaria decumbens em sistema silvipastoril, Ciênc. agrotec., Lavras, v. 29, n. 3, p. 668-675, maio/jun., 2005

LENZA, E. e KLINK, C. A, Comportamento fenológico de espécies lenhosas em um cerrado sentido restrito de Brasília, DF. Revista Brasil. Bot., v. 29, n.4, p.627-638, out.-dez. 2006 


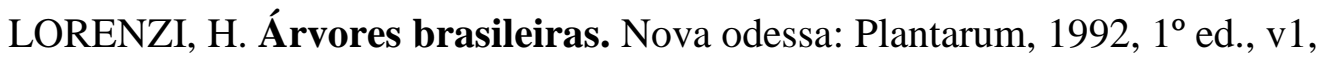

LORENZI, H. Árvores brasileiras: Manuel de identificação e cultivo de plantas arbóreas do Brasil. Nova Odessa. São Paulo: Instituto Plantarum, 2000, $4^{\circ}$ ed., v.1, , p. 368.

LORENZI, H. Árvores brasileiras: Manual de identificação e cultivo de plantas

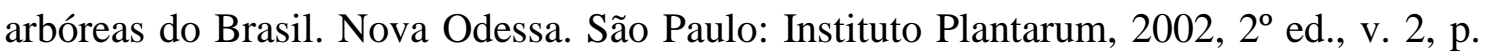
368.

LUDWIG, F. et al. The influence of savanna trees on nutrient, water and light availability and the understorey vegetation. Plant Ecology, v. 170, p. 93-105, 2004

LUNT, D. Technical Report 18. Effects of Stock Grazing on Biodiversity Values in Temperate Native Grasslands and Grassy Woodlands in SE Australia: A Literature Review. Environment ACT, Canberra. 2005.

MACEDO, G. A. R. Dieta de novilho em pastagem nativa de Cerrado - Fazenda Santa Rita - Município de Prudente de Morais. Belo Horizonte, EPAMIG, 1978. $27 \mathrm{p}$.

MAESTRE, F.T. et al., Refining the stress-gradient hypothesis for competition and facilitation in plant communities. Journal of Ecology, n. 97, p.199-205, 2009

MAIA, G. N. Caatinga: árvores e arbustos e suas utilidades. $1^{\circ}$ edição, São Paulo: D\&Z Computação gráfica e editora. 2004.

MAINIERI, Calvino; CHIMELO, Joao Peres. Fichas de caracteristicas das madeiras brasileiras. 2. ed. São Paulo: Instituto de Pesquisas Tecnológicas do Estado de São Paulo, 1989. 418 p.

MARTIN, G. O. Mantenga la sombra en sus potreros y reduzca el estrés animal. Revista Producción , 2002

MARTUSCELLO, J. A. et al. Produção de gramíneas do gênero Brachiaria sob níveis de sombreamento. R. Bras. Zootec., v.38, n.7, p.1183-1190, 2009.

MELLO G. W. S. et al., Plantas tóxicas para ruminantes e eqüídeos no Norte Piauiense. Pesq. Vet. Bras. v. 30, n. 1, p. 1-9, 2010.

MELO, J. T.; ZOBY, J. L. F. Espécies para arborização de pastagem. Planaltina: Embrapa, 2004. (Comunicado técnico 113). 
MELOTTO, A. et al. Sobrevivência e crescimento inicial em campo de espécies florestais nativas do Brasil central indicadas para sistemas silvipastoris. Revista Árvore, Viçosa, v. 33, n. 3, p. 425- 432, 2009.

MENDONÇA R. C, FELFILI J. M., WALTER B. M. T., et al., 2008. Flora vascular do bioma Cerrado: checklist com 12.356 espécies. In: Sano, S. S.; Almeida; Ribeiro, J. (eds.), Cerrado: ecologia e flora. Brasília, DF: Embrapa Informação Tecnológica, p. $423-1279$.

MLAMBO, D.; NYATHI, P.; MAPAURE, I. Influence of Colophospermum mopane on surface soil properties and understorey vegetation in a southern African savanna. Forest Ecology \& Management, v. 212, p.394-404, 2005

MIMENZA, H. E. Tree resources in tradicional silvopastoral, systems and their impact on productivity and nutritive value of pastures in the dry tropics of Costa Rica. Tropical agriculture research and higher education center, Turrialba, p. 160, 2007

MONTAGNINI, F.; FANZERES, A. DA VINHA, S. G. Studies on Restoration Ecology in the Atlantic Forest region of Bahia, Brazil. Interciencia, v. 19, p.323-330, 1994

MOUSTAKAS, A. et al. Facilitation or competition? Tree effects on grass biomass across a precipitation gradient. Plos One, v. 8, n. 2, e57025, 2013

MUOGHALU, J. I.; ISICHEI, A. O. Effect of tree canopy cover on grass species in Nigerian Guinea savanna. Tropical Agriculture, Trinidad, v. 71, n. 2, p.97-101, 1995

MURGUEITIO, R.E.; IBRAHIM, M. Ganadería y medio ambiente en América Latina. In: MURGUEITIO, E.; CUARTAS, C.; NARANJO, J. F (eds.). Ganadería del futuro: Investigación para el desarrollo. CIPAV, Cali, Colombia. 2008, p. 19-40.

MURGUEITIO, R.E. et al. Native trees and shrubs for the productive rehabilitation of cattle ranching lands. Forest Ecology and Management. v. 261, p.1654-1663, 2011

NASCIMENTO, M. P. S. C. B. Plantas do Semi-Árido: Conhecimento e uso no Assentamento Marrecas. Teresinha: EMBRAPA Meio-Norte, 2008. 180 p.: il.

NASCIMENTO, V. T. Estratégias rurais de uso e manejo de plantas para construções de cercas em uma área de Caatinga no município de Caruaru, Pernambuco. Recife, 2007. Dissertação: Pós Graduação em Botânica, Universidade Federal Rural de Pernambuco, 2007. 
NICODEMO, M. L. F. et al. Sistemas Silvipastoris - Introdução de Árvores na Pecuária do Centro-Oeste Brasileiro. Campo Grande: Embrapa Gado de Corte, 2004 OLIVEIRA, D. M. T. Morfologia de plântulas e plantas jovens de 30 espécies arbóreas de Leguminosae. Acta Bol. Bras, v.13, n.3, p.263-269. 1999.

PACIULLO, D.S.C.; CAMPOS, N.R.; GOMIDE, C.A.M. et al. Crescimento do pasto de capim braquiária influenciado pelo nível de sombreamento e pela a estação do ano. Pesquisa Agropecuária Brasileira, v.43, n.7, p.317-323, 2008.

PACIUllo D. S. C., CASTRO, C. R. T., GOMIDE, C. A. M. et al. Performance of dairy heifers in a silvopastoral system. Livestock Science, v.141, p.166-172, 2011

PAUlA, J. E. de.; ALVES, J. L. de H. Madeiras nativas: anatomia, dendrologia, dendrometria, produção e uso. Brasília: Gutemberg, 1997. 543p.

PAULA, J. E. de.; COSTA, K. P. Densidade da madeira de 932 espécies nativas do Brasil. Porto Alegre, Cinco continentes, 2011.

PEDRONI, F.; SANCHEZ, M. e SANTOS, F. A. M. Fenologia da copaíba (Copaifera langsdorffii Desf. - Leguminosae, Caesalpinioideae) em uma floresta semidecídua no sudeste do Brasil Revista Brasil. Bot., v.25, n.2, p.183-194, jun. 2002

PIRANI, J. R.; CORTOPASSI-LAURINO, M. Flores e abelhas em São Paulo. São Paulo: EDUSP: FAPESP, 1993. 192 p.

PIRANI, F. R. ET AL., Fenologia de uma comunidade arbórea em cerrado sentido restrito, Barra do Garças, MT, Brasil Acta bot. bras. v.23, n. 4, p.1096-1109, 2009.

PORFÍRIO-DA-SILVA, V. Ideótipo de espécie arbórea para Sistemas de Integração Lavoura-Pecuária-Floresta. In: LAURA, V. A., ALVES, F. V., ALMEIDA, R. G. Sistemas agroflorestais: a agropecuária sustentável, Brasília : Embrapa, 2015. 208 p POTT, A.; POTT, V. J. Inventário da flora apícola do pantanal em Mato Grosso do Sul. Corumbá, MS: EMBRAPA-CPAP, 1986. 16 p. (EMBRAPA-CPAP. Pesquisa em andamento, 3)

POTT, E. B.; POTT, A. Níveis de nutrientes em plantas não-gramíneas pastejadas por bovinos na sub-região dos paiaguãs, do Pantanal Mato-grossense. Pesq. Agropec. Bras., Brasília, v.22, n.(11/12): 1293-1299, nov./dez. 1987.

POTT, A. Pastagens no Pantanal. Corumbá-MS, EMBRAPA-CPAP, 1988. 58p. (EMBRAPA-CPAP. Documentos, 7) 
POTT, A.; POTT, V. J. Plantas do Pantanal. Corumbá: EMBRAPA-CPAP; Brasília, DF: EMBRAPA-SPI, 1994. 320p.

POTT, A.; POTT, V. J. Plantas Nativas potenciais para sistemas agroflorestais em Mato Grosso do Sul. In: SEMINÁRIO SISTEMAS AGROFLORESTAIS E DESENVOLVIMENTO SUSTENTÁVEL, 2003, Campo Grande. Anais: Campo Grande: Embrapa, 2003.

POTT, A.; POTT, V. J.. SOUZA, T. W. Plantas daninhas de pastagem na Região dos Cerrados. Campo Grande, MS: EMBRAPA Gado de Leite,2006. p.336.

RAMOS, A.; et al. Levantamento florestal da Estação Experimental Morretes I do Instituto Agronômico do Paraná. In: CONGRESSO FLORESTAL E DO MEIO AMBIENTE DO PARANÁ, 3., 1991, Curitiba. Anais. Curitiba: Instituto Florestal do Paraná: Associação Paranaense de Engenharia Florestais, 1991. p. 113 - 124.

RATTER J. A., BRIDGEWATER S. \& RIBEIRO J. F. Analysis of the Floristic Composition of the Brazilian Cerrado Vegetation III: Comparison of the Woody Vegetation of 376 Areas. Edinburgh Journal of Botany, v 60 n. 01, p.57-109, 2003

RESTREPO, C. Relaciones entre la cobertura arbórea en potreros y la producción bovina em fincas ganaderas em el trópico seco, Cañas, Costa Rica. 2002, 102p. Dissertação: CATIE, Turrialba, Costa Rica, 2002

RIZZINI, C. T. Aspectos ecológicos da regeneração em algumas plantas do cerrado. In: SIMPÓSIO SOBRE O CERRADO, 3., 1971, São Paulo. Anais. São Paulo: Ed; Blücher/USP, 1971 p.61-64. Editado por M. G. Ferri.

RIZZINI, C. T.; MORS, W. B. Botânica econômica brasileira. São Paulo, EPU, Ed. da Universidade de São Paulo, 1976. p.206.

ROCHA, F. T.; et al. Durabilidade natural de madeiras em contato com o solo: V avaliação final (20 anos). Revista do Instituto Florestal, São Paulo, v. 12, n. 1, p. 5966, 2000.

SAlOMÃO, A. N. et al. Germinação de Sementes E Produção de Mudas de Plantas Do Cerrado. Brasília, DF: Rede de Sementes do Cerrado. 2003.

SAMARAKOOM, S. P.; WILSON, J. R.; SHELTON, H. M. Growth, morphology and nutritive value of shaded Stenotaphrum secundatum, Axonopus compressus and 
Pennisetum clandestinum. Journal of Agricultural Science, Cambridge, v.114, p. 161$169,1990$.

SANTOS, S. A.; et al. Composição Botânica da Dieta de Bovinos em Pastagem Nativa na Sub-Região da Nhecolândia, Pantanal. Rev. Bras. Zootecnia, v.31, n.4, p.16481662,2002

SANTOS, S. A.; et al. Grau de Preferência e Índice de Valor Forrageiro das Pastagens Nativas Consumidas por Bovinos no Pantanal. Corumbá, MS 2003. EMBRAPA: Boletim de Pesquisa e Desenvolvimento 49.

SANTOS, S. A. et al. Sistemas Silvipastoris Naturais e Alterados no Pantanal. Rev. Bras. de Agroecologia, v. 4, n. 2, p. 1556-1559, 2009.

SHANLEY, P., SERRA, M., MEDINA, G. (ed.) Frutíferas e plantas úteis na vida amazônica. CIFOR, 2010, 320p.

SILVA, J. A. Gado come folhas de árvores e arbustos dos cerrados. Planaltina, EMBRAPA-CPAC, 1986. 2p. (EMBRAPA-CPAC. Noticiário, 136).

SILVA, R. G. Predição da configuração de sombras de árvores em pastagens para bovinos. Eng. Agrícola, Jaboticabal, v. 26, n.1, p.268-281. Jan-abr, 2006.

SILVA, J. A. R. et al. Conforto térmico de búfalas em sistema silvipastoril na Amazônia Oriental. Pesquisa Agropecuária Brasileira, Brasília, v. 46, n. 10, p. 1364-1371, 2011. SILVA JUNIOR, M. C. 100 árvores do cerrado: guia de campo. Brasília: Rede de Sementes do Cerrado, 278 p. il. 2005.

SILVA JUNIOR, M. C. da. 100 árvores urbanas - Brasília: guia de campo. Brasília. Ed. Rede de Sementes do Cerrado, 2010. p.: il

SILVA JUNIOR, M. C. et al. Guia dos observadores de árvores: tronco, copa e folha. Brasília: Rede de Sementes do Cerrado, 252 p. il. 2014.

SILVÉRIO, D. V.; E LENZA, E. Fenologia de espécies lenhosas em um cerrado típico no Parque Municipal do Bacaba, Nova Xavantina, Mato Grosso, Brasil. Biota Neotrop., v. 10, n. 3, 2010

SOLORIO, J.; ARMENDARIZ, I.; Ku, J. Chemical composition ad in vitro dry matter digestibility of some fodder trees from South-East Mexico. Livestock Research for Rural Development. 2000. 
SOUSA, L. F. et al.. Nutritional evaluation of "Braquiarão" grass in association with "Aroeira" trees in a silvopastoral system. Agroforestry Systems. v. p. 79, 179-189. 2010

TEIXEIRA, S. S.; MACHADO, A. L. T.; REIS, A. V.; OLDONI, A. Caracterização da produção agroecológica do sul do Rio Grande do Sul e sua relação com a mecanização agrícola. Engenharia Agrícola, Jaboticabal, v. 29, p. 162-171, 2009.

TOKARNIA, C. H.; DÖBEREINER J.; PEIXOTO, P. V. Poisonous plants affecting livestock in Brazil. Toxicon, v. 40, n. 12, p. 1635-1660, 2002.

TOLEDO, V. M.; BARRERA-BASSOLS, N. A etnoecologia: uma ciência pós-normal que estuda as sabedorias tradicionais. In: SILVA, V. A.; ALMEIDA, A. L. S.; ALBUQUERQUE, U. P. Etnobiologia e Etnoecologia: pessoas \& natureza na América Latina. Recife: NUPPEA, 2010. p.13- 36

URBANO, D.; DÁVILA, C.. Leguminosas arbóreas para optimizar la producción de leche y Carne. In: González C. y E. Soto. (Eds.). Manual de Ganadería Doble Propósito. Maracaibo: Fundación GIRARZ. Editorial Astro data, 2005, p. 213-218.

VALE, A. T.; BRASIL, M. A. M.; LEÃO, A. L. Quantificação e caracterização energética da madeira e casca de espécies do cerrado. Ciência Florestal. v. 12, n. 1, p. 71-80, 2002.

VALlilO, M. I.; TAVARES, M.; AUED, S. Composição química da polpa e da semente do fruto do cumbaru (Dipteryx alata Vog.) - caracterização do óleo da semente. Revista do Instituto Florestal, São Paulo, v. 2, n. 2, p. 115-125, 1990.

VIDA, J. M. et al. Preservação De Madeiras No Brasil: Histórico, Cenário Atual E Tendências. Ciência Florestal, v. 25, n. 1, p. 257-271, 2015

VIEIRA, D. L. M. Tropical dry-forest regeneration from root suckers in Central Brazil. Journal of Tropical Ecology, n. 22, p. 353-357, 2006.

VIEIRA, R. F.; et al. Frutas nativas da região Centro-Oeste do Brasil. Brasília, DF, EMBRAPA Informação Tecnológica, 2010. 322 p.: il.

YAMAMOTO, W., DEWI, I. A., IBAHIM, M., Effects of silvopastoral areas on milk production at dual-purpose cattle farms at the semi-humid old agricultural frontier in central Nicaragua. Agroforestry Systems. v. 94, p. 368-375, 2007. 


\section{CAPÍTULO 4}

\section{SEMEADURA DIRETA DE ÁRVORES DE CERRADO PARA ESTABELECIMENTO DE SISTEMAS SILVIPASTORIS: EMERGÊNCIA, SOBREVIVÊNCIA E CRESCIMENTO AOS 42 MESES}

\section{INTRODUÇÃO}

Os sistemas silvipastoris - SSP encontrados no Cerrado são geralmente formados por árvores remanescentes da vegetação original, deixadas pelo desmatamento seletivo para formação das pastagens e também pela regeneração natural de indivíduos arbóreos mantidos durante a "limpeza" destes pastos. Esta tem sido a maneira mais frequente entre os SSPs que possuem diversidade de árvores nativas no Cerrado. Porém, o tipo de produção pecuária que domina no Brasil e no Cerrado são grandes áreas com cultivo de gramíneas exóticas (DIAS FILHO, 2011; BRASIL, 2015). Muitas destas áreas, principalmente as mais antigas e tecnificadas, possuem baixa ou nenhuma regeneração natural de espécies arbóreas. Nessas áreas, para reintroduzir árvores será necessário plantá-las por sementes ou mudas, com métodos baratos e efetivos para que sejam convidativos aos pecuaristas.

Em pastagens sem árvores, o mais comum entre os pecuaristas que desejam ter SSPs, tem sido o plantio de mudas de uma ou poucas espécies madeireiras de rápido crescimento, com maior frequência de espécies exóticas, como Eucalyptus sp, Pinus sp e Khaya ivorensis (RIBASKI e RIBASKI, 2015; GONTIJO NETO et al., 2015). No Cerrado, poucas vezes as espécies nativas são incluídas quando se trata de plantios de SSPs, pois são priorizadas as espécies de silvicultura conhecida, com mercado estabelecido e de rápido crescimento e retorno econômico (MONTOYA e BAGGIO, 2000). Porém, as espécies nativas do Cerrado são mais resistentes à forte sazonalidade climática e a solos ácidos e de baixa fertilidade, o que diminui a demanda de insumos externos e possibilita maior conservação da biodiversidade local (CASTRO e PACIULLO, 2006; OLIVEIRA-FILHO, 1994).

O plantio de mudas, seja para compor os sistemas produtivos ou recuperar áreas degradas, apresenta algumas dificuldades, como: o alto custo de produção e 
transporte (CAMARGO et al. 2002, COLE et al. 2011); pouca diversidade de espécies nos viveiros locais (FONSECA et al., 2001; BARBOSA et al., 2003) danos das mudas com o transporte e mortalidade após o plantio em campo, devido a mudança de ambiente, ataque de formigas, passagem de fogo, falta de chuvas. Um método promissor para reintroduzir árvores é a semeadura direta. O plantio tende a ser menos trabalhoso, apresenta menor custo de implementação (ENGEL e PARROTTA, 2001; COLE ET AL., 2011; PALMA e LAURANCE, 2015; CAMPOS-FILHO et al., 2013) e há viabilidade de mecanização (CAMPOS-FILHO et al., 2013). Os plantios tendem a ser mais biodiversos e adensados (PALMA e LAURANCE, 2015; CAMPOS-FILHO et al., 2013). A planta já cresce em ambiente definitivo, portanto não sofre com a adaptação em campo, e há possibilidade de selecionar os indivíduos mais vigorosos, e bem posicionados, já que costuma-se plantar as sementes em abundancia. Dentre as desvantagens, pode-se citar a necessidade de maior tempo de acompanhamento e manejo (ARAKI, 2005; SILVA et al., 2015;), a baixa germinação e estabelecimento para algumas espécies, principalmente as com sementes pequenas, além da predação das plântulas e sementes (DOUST et al., 2006; PALMA e LAURANCE, 2015).

A semeadura direta de árvores e arbustos vem sendo mais praticada para restauração da vegetação original (principalmente em ambientes florestais) e em plantios de sistemas agroflorestais, mas ainda é pouco frequente sua utilização para plantio de sistemas silvipastoris. Para formar SSP por meio da semeadura direta há gargalos adicionais como a competição severa com espécies de gramíneas exóticas adensadas (HOOPER et al., 2002; SUN e DICKINSON, 1996; DOUST et al., 2008) e a necessidade do rápido crescimento das árvores para atingir o porte mínimo que permita o retorno do gado ao pasto. Existem diversos estudos desta técnica em diferentes ambientes que tiveram sucesso (BONILLA-MOHENO e HOLL, 2010; DOUST et al, 2006), inclusive em pastagem abandonada (AGUIRRE et al, 2015) e no bioma Cerrado usando espécies nativas (SILVA et al., 2015; LIMA, 2016; PELLIZARO, 2016).

Neste capítulo pretendeu-se conhecer a emergência, o estabelecimento e o crescimento de 10 espécies arbóreas de valor econômico, especialmente dos frutos, a partir da semeadura direta. Os resultados servirão para subsidiar o planejamento de plantios de reintrodução de espécies de árvores nativas em SSP, para fins de aumento de biodiversidade, serviços ambientais e funcionalidade às pastagens, estabelecendo sombra para o gado e produção de frutos e madeira. Espera-se que as espécies semeadas 
sejam estabelecidas com sucesso por meio da semeadura direta, pois têm sementes médias e grandes (PALMA e LAURANCE, 2015, CECCON et al. 2016).

\section{MATERIAIS E MÉTODOS}

\section{Área de estudo}

O experimento foi implantado em novembro de 2012 na Fazenda Entre Rios, na região do PAD-DF, zona rural de Planaltina, sudeste do DF (1556'43" S; 47²8'04" W). O clima é do tipo Aw (Köppen), tropical com duas estações bem definidas, verão chuvoso, inverno seco, a precipitação média anual entre os anos de 2013 e 2015 foi de 1256 mm (INMET, 20017) e o solo é do tipo neossolo litólico (REATTO et al., 2000). A área de pastagem de 2 ha, estava ativa e bem formada por capim braquiária (Urochloa decumbens), tinha apenas uma árvore isolada de angico (Anadenanthera colubrina (Vell.) Brenan.) Desde a implantação do experimento a área encontra-se sem pastoreio de gado.

\section{Espécies estudadas}

As espécies selecionadas para o experimento atenderam ao critério de ser nativa do cerrado sentido restrito e possuir valor econômico (frutos, madeira, resina). Foram plantadas 10 espécies arbóreas (Tabela 1).

Tabela 1- Espécies arbóreas nativas do Cerrado utilizadas em experimentos de semeadura direta para formar SSP realizados em Planaltina, DF.

\begin{tabular}{|c|c|c|c|c|}
\hline Espécie & Família & $\begin{array}{l}\text { Nome } \\
\text { popular }\end{array}$ & Usos & $\begin{array}{l}\text { Peso fresco } \\
\text { de } 1000 \\
\text { sementes } \\
\text { (g) }\end{array}$ \\
\hline $\begin{array}{l}\text { Anacardium occidentale } \\
\text { L. }\end{array}$ & Anacardiaceae & Caju & $\begin{array}{l}\text { Frutífera }{ }^{4,6} \\
\text { Melífera }^{8,9}\end{array}$ & $4480^{3}$ \\
\hline $\begin{array}{l}\text { Anonoa crassiflora } \\
\text { Marti* }\end{array}$ & Anacardiaceae & Araticum & Frutífera ${ }^{4,22,24}$ & $680^{1}$ \\
\hline $\begin{array}{l}\text { Byrsonima verbascifolia } \\
\text { (L.) DC. }\end{array}$ & Malpighiaceae & Murici & $\begin{array}{l}\text { Frutífera }{ }^{4,22,25} \\
\text { Melífera }^{8,30}\end{array}$ & $820^{1}$ \\
\hline $\begin{array}{l}\text { Caryocar brasilienses } \\
\text { Cambess* }\end{array}$ & Caryocaraceae & Pequi & $\begin{array}{l}\text { Frutífera }^{4,5,22} \\
\text { Madeireira }^{6,7} \\
\text { Melífera }^{8,9}\end{array}$ & $4850^{1}$ \\
\hline $\begin{array}{l}\text { Copaifera langsdorffi } \\
\text { Desf.* }\end{array}$ & Fabaceae & Copaíba & $\begin{array}{l}\text { Madeireira } \\
\text { Melífera }^{8,12}\end{array}$ & $470^{1}$ \\
\hline
\end{tabular}




\begin{tabular}{|c|c|c|c|c|}
\hline & & & Medicinal $^{5,13}$ & \\
\hline Dipteryx alata Vogel & Fabaceae & Baru & $\begin{array}{l}\text { Forrageira }{ }^{4,26,27} \\
\text { Frutífera }^{4,24,25} \\
\text { Madeireira }^{15,28} \\
\text { Melífera }^{29,30}\end{array}$ & $1200^{1}$ \\
\hline $\begin{array}{l}\text { Eugenia dysenterica } \\
\text { DC.* }\end{array}$ & Myrtaceae & Cagaita & $\begin{array}{l}\text { Frutífera }{ }^{4,22,25} \\
\text { Melífera }^{8,25}\end{array}$ & $750^{1}$ \\
\hline $\begin{array}{l}\text { Hymenaea stignocarpa } \\
\text { Mart.* }\end{array}$ & Fabaceae & Baru & $\begin{array}{l}\text { Madeireira }{ }^{17,18} \\
\text { Frutífera }^{4,14,22} \\
\text { Melífera }^{18,20}\end{array}$ & $3900^{1}$ \\
\hline Syagrus oleracea Becc & Arecaceae & Gueroba & $\begin{array}{l}\text { Frutífera }^{22,23} \\
\text { Forrageira }^{23}\end{array}$ & $33810^{2}$ \\
\hline $\begin{array}{l}\text { Tachigali subvelutina } \\
\text { Tul* }\end{array}$ & Fabaceae & Carvoeiro & $\begin{array}{l}\text { Madeireira } \\
\text { Melífera }^{8,20}\end{array}$ & $90^{1}$ \\
\hline
\end{tabular}

*Espécies estudadas no capítulo 3 desta tese. 1-SALOMÃO et al. 2003; 2-NASCENTE et al. 2000; 3PELLIZZARO, 2016. 4-VEIRA et al., 2010; 5-IBGE, 2015; 6-IBGE, 2002; 7-CORRÊA, 1974; 8- de BRANDÃO \& FERREIRA, 1991; 9-de BASTOS et al., 1998; 10-SILVA-JUNIOR, 2012; 11- LORENZI, 2000; 12- BASTOS et al., 1993; 13-SHANLEY et al., 2010; 2013; 15-CAMPOS FILHO \& SARTORELLI, 2015; 17- RIZZINI e MORS, 1976; 18- CARVALHO, 2006; 19-CARVALHO. 2014; 20- DE ALMEIDA et al., 2003; 21-JENRICH,1989; 22-ALMEIDA, 1998; 23- DE ALMEIDA, 2000; 24ALMEIRA et al., 2008, 25- ALMEIDA et al., 1998; 26-POTT e POTT, 2003, 27- SANTOS, 2003; 28MAINIERI \& CHIMELO, 1989; 29- CARVALHO, 2003; 30- POTT \& POTT, 1986

\section{Estabelecimento do experimento}

O plantio foi realizado ao longo de 12 linhas posicionadas no sentido leste-oeste, com 60 metros de comprimento, distantes 20 metros entre si (Figura 1). Primeiramente, toda a área do experimento foi roçada com trator, o local das linhas de plantio foi gradeado e, em seguida, um sulcador acoplado ao trator, sulcou as linhas a $30 \mathrm{~cm}$ de profundidade. Nas linhas realizou-se o destorroamento e retirada de torrões muito grandes dos sulcos, manualmente com enxadões. O capim roçado nas entrelinhas de 20 metros foi enleirado com rastelo e disposto ao longo das linhas, de ambos os lados, numa faixa de $50 \mathrm{~cm}$ de cada lado da linha, se tocando no centro da linha, mas permitindo abertura para a emergência das plântulas. A cobertura do solo com palhada foi feita para protegê-lo de erosão, manter sua umidade e dificultar a germinação da braquiária. Não foram utilizados fertilizantes.

As sementes foram enterradas a uma profundidade de aproximadamente duas vezes sua espessura. As sementes foram plantadas nas 12 linhas, sendo uma semente de cada espécie por metro linear, em ordem aleatória, totalizando 10 sementes por metro linear. Portanto, o desenho experimental teve 12 repetições (linhas), cada uma com 60 
sementes de cada espécie. O plantio foi realizado em novembro de 2012, exceto $A$. crassiflora, $C$. brasilienses, $B$. verbascifolia que foram plantadas no mês de fevereiro do ano sequente, época de sua dispersão. Sementes de $S$. oleracea foram deixadas de molho em cresol, popularmente chamado de creolina, por 24 horas, para prevenir ataque de insetos. Sementes de D. alata e S. oleracea foram plantadas sem retira-las do fruto, sementes de T. subvelutina foram retiradas do fruto.

As sementes foram coletadas em áreas de cerrado do DF e para cada espécie coletou-se as sementes de no mínimo 5 árvores matrizes. A germinabilidade foi também avaliada no laboratório de sementes da EMBRAPA Cerrados. As sementes foram colocadas para germinar em papel germitest, exceto caju que foi colocado em gerbox com vermiculita, em câmera de germinação com 12 horas luz e $30{ }^{\circ} \mathrm{C}$ de temperatura. Para A. crassiflora, $C$. brasilienses, B. verbascifolia infelizmente não foram realizados estes testes em laboratório.

O experimento foi manejado no início do período chuvoso nos anos de 2013, 2014 e 2015, quando as entre linhas eram roçadas com trator e a linha do plantio capinada manualmente, $50 \mathrm{~cm}$ de cada lado aproximadamente. Em um metro de cada lado das linhas foi aplicado o herbicida glifosato com pulverizador costal para controlar o capim. As formigas foram controladas sempre que se percebia sua presença no experimento.

A emergência e a sobrevivência das espécies foram avaliadas mensalmente em todas as linhas de plantio, durante os cinco primeiros meses. Após este período muitas plântulas perderam suas folhas, portanto, optou-se em retomar as medidas em dezembro de 2013, 8 meses após a última medição, e a partir daí as medidas foram feitas anualmente. Todos indivíduos que emergiram tiveram suas posições anotadas, que correspondia a distância do início da linha até a planta, medidos por uma trena de 100 metros. Com isso, foi possível verificar a emergência e a sobrevivência das plântulas. Anualmente foram medidos a altura total das plântulas com régua graduada em milímetros, o diâmetro do colo com paquímetro digital, e número de folhas. 


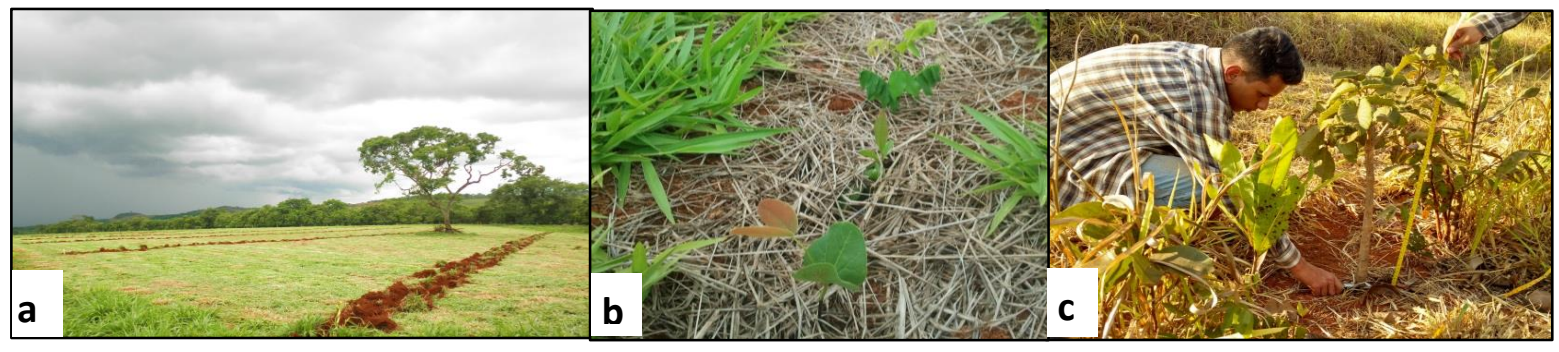

Figura 1: Experimento de semeadura direta de árvores nativas do cerrado para formar SSP, localizado em Planaltina, DF. a: preparo da área para implantar o experimento; b: plântulas em solo coberto com palhada; c: medidas de diâmetro e altura das plantas.

\section{RESULTADOS}

Foram plantadas 7.200 sementes, das quais $47,8 \%$ emergiram e $26,5 \%$ estavam vivas após 42 meses do plantio. Eugenia dysenterica, D. alata, H. stigonocarpa, A. occidentale, S. oleracea, C. langsdorffii tiveram emergência superior a 50\%. Caryocar brasiliense e A.crassiflora tiveram porcentagem intermediário de emergência, $40 \%$ e $35 \%$ respectivamente, mas seus valores de estabelecimento foram 51 e $60 \%$ (tabela 2). As espécies $T$. subvelutina e $B$. verbascifolia tiveram baixa porcentagem de emergência (7\% e zero, respectivamente) e o estabelecimento de ambas foi nulo. Eugenia dysenterica teve a maior porcentagem de estabelecimento (79\%), por outro lado, $C$. langsdorffii teve alta mortalidade (85\%). Após 42 meses da semeadura direta havia 1909 indivíduos estabelecidos, o que representa 2,7 plantas por metro linear. Dentre as dez espécies utilizadas, sete apresentaram estabelecimento superior a $20 \%$ das sementes plantadas.

Tabela 2: Valores de emergência em campo, geminação em laboratório e sobrevivência de dez espécies arbóreas nativas do Cerrado com valor econômico plantadas em área de pastagem para formar SSPs, em Planaltina, DF.

\begin{tabular}{|l|c|c|c|c|c|l|c|}
\hline Espécie & \multicolumn{2}{|l|}{$\begin{array}{l}\text { Emergência } \\
\text { em campo }\end{array}$} & $\begin{array}{l}\text { Ger } \\
\text { mina } \\
\text { ção } \\
\text { em } \\
\text { lab. }\end{array}$ & $\begin{array}{l}\text { Estabelecime } \\
\text { nto após 42 } \\
\text { meses } \\
\text { /emergência }\end{array}$ & $\begin{array}{l}\text { Estabeleci } \\
\text { mento } \\
\text { após 42 } \\
\text { meses/ } \\
\text { sementes } \\
\text { plantadas }\end{array}$ & $\begin{array}{l}\text { Representati } \\
\text { vidade das } \\
\text { sp. dentre as } \\
\text { plantas } \\
\text { estabelecida } \\
\text { s após 42 } \\
\text { meses }\end{array}$ \\
\hline & $\mathrm{n}$ & $\%$ & $\%$ & $\mathrm{n}$ & $\%$ & $\%$ & $\%$ \\
\hline Eugenia dysenterica & 678 & 93,7 & $0 *$ & 538 & 79,4 & 73,3 & 28,2 \\
\hline $\begin{array}{l}\text { Dipteryx alata } \\
\text { Hymenaea }\end{array}$ & 550 & 76,1 & 71 & 185 & 33,6 & 25,2 & 9,7 \\
\hline stigonocarpa & 479 & 65,3 & 44 & 297 & 62,0 & 40,5 & 15,6 \\
\hline Syacardium occidentale & 429 & 58,6 & 53 & 212 & 49,4 & 28,9 & 11,1 \\
\hline
\end{tabular}




\begin{tabular}{|l|c|c|c|c|c|c|c|}
\hline Copaifera langsdorffii & 374 & 51,5 & 98 & 57 & 15,2 & 7,8 & 3,0 \\
\hline Caryocar brasiliense & 295 & 40,3 & -- & 150 & 50,8 & 20,4 & 7,9 \\
\hline Annona crassiflora & 257 & 35,1 & -- & 154 & 60,0 & 21,0 & 8,1 \\
\hline Tachigali subvelutina & 52 & 7,1 & 46 & 0 & 0 & 0,0 & 0,0 \\
\hline Byrsonima verbascifolia & 2 & 0,0 & -- & 2 & 0 & 0,3 & 0,1 \\
\hline Total & 3443 & -- & -- & 1909 & 47,8 & 26,5 & 100 \\
\hline
\end{tabular}

*sementes fungadas

As espécies D. alata, A. occidentale, H.stigonocarpa e C. langsdorffii apresentaram emergência rápida (figura 2). No primeiro censo (30 dias após o plantio), a maior parte das sementes destas espécies já havia emergido. Syagrus oleracea e E. dysenterica apresentaram emergência mais demorada e distribuída ao longo dos meses com um pico de emergência 3 meses após o plantio. Caryocar brasiliensis e A. crassiflora, que foram plantados em fevereiro de 2013, emergiram na estação chuvosa seguinte, sendo que em dezembro de 2013 a maior parte já havia emergido.
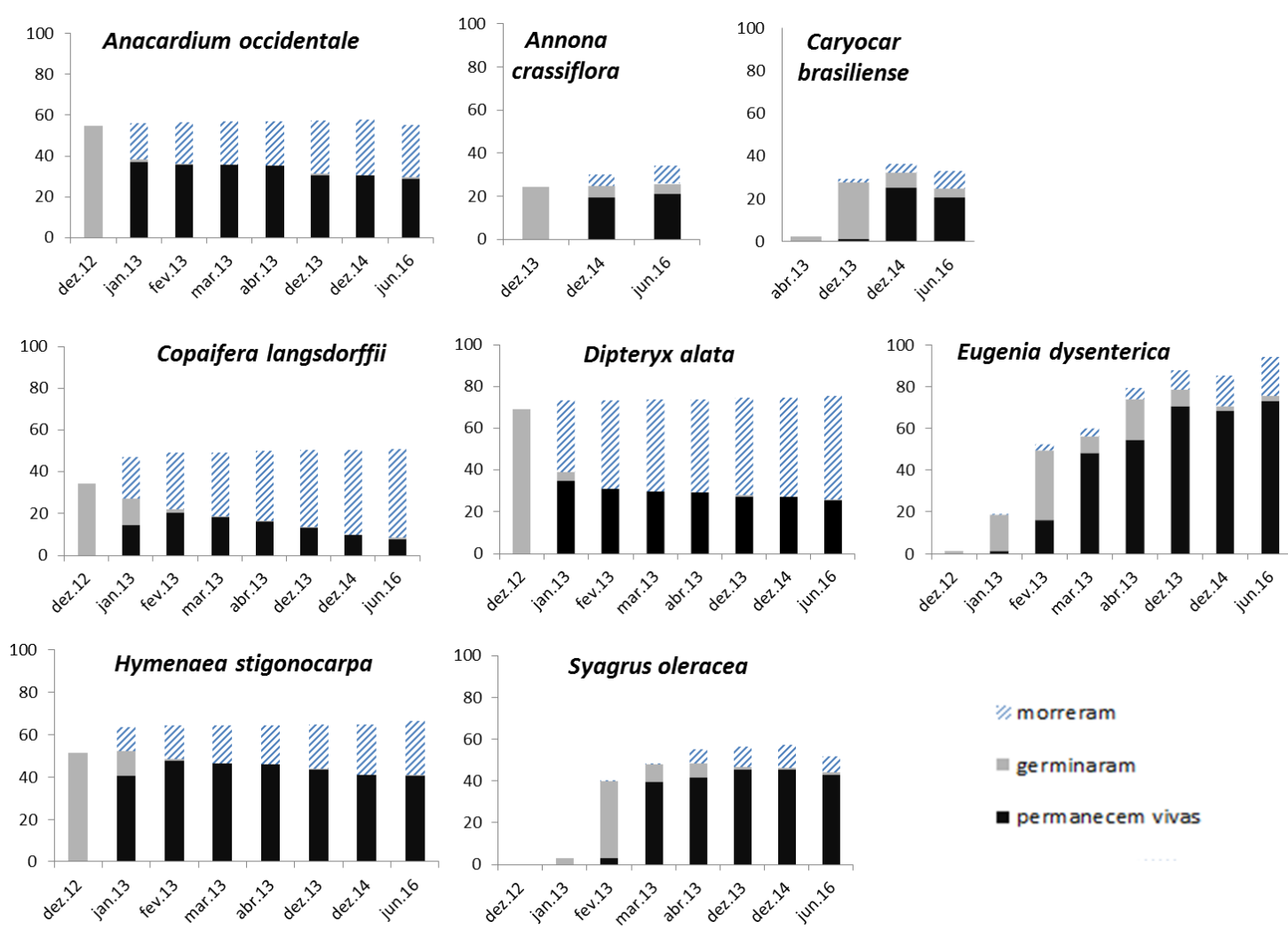

Figura 2: Porcentagem de sementes que emergiram, se mantiveram vivas e morreram em experimento de semeadura direta com espécies de cerrado sentido restrito em pastagem localizada em Planaltina, DF.

Anacardium occidentale e Caryocar brasiliense apresentaram os maiores valores de crescimento para diâmetro, altura e numero de folhas, enquanto Eugenia dysenterica e Copaifera langsdorffii tiveram os menores valores de diâmetro e altura. De modo geral, o crescimento das plantas até os 42 meses de idade foi muito lento, 
atingindo em média para as espécies de crescimento mais rápido ( $C$. brasiliensis, $A$. occidentale) 28 e $26 \mathrm{~cm}$ de altura, respectivamente.
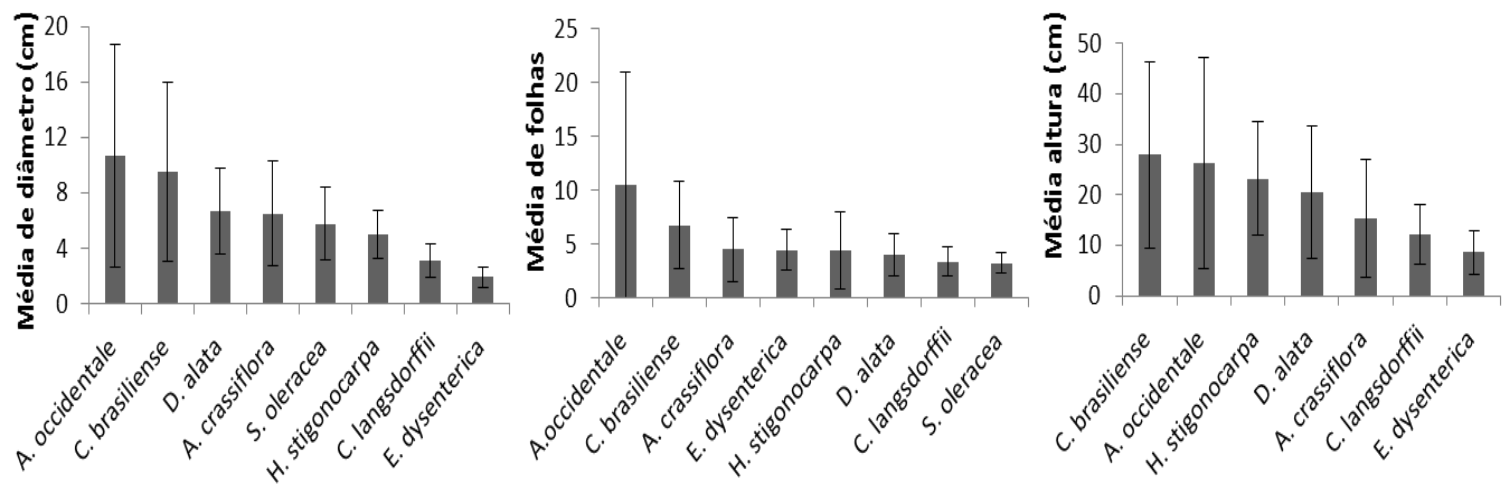

Figura 3: Crescimento (altura, diâmetro e número de folhas) de oito espécies nativas do cerrado, plantadas por semeadura direta em área de pastagem localizada em Planaltina, DF. * A altura de Syagrus oleracea não foi medida devido sua gema apical estar muito próxima ao solo.

\section{DISCUSSÃO}

A alta porcentagem de emergência e estabelecimento de sete das dez espécies plantadas são fortes indícios do potencial da semeadura direta de árvores nativas com sementes grandes, como alternativa que parece ser mais barata que o uso de mudas para arborização de pastagens. O espaçamento de $10 \mathrm{~cm}$ entre sementes nas linhas de plantio proporcionou alta densidade de plantas por metro linear, o que representa uma vantagem pois admite fazer escolhas dos indivíduos mais vigorosos e bem posicionados em relação as outras espécies e ao sombreamento do SSP como um todo, permitindo opções de seleção de indivíduos de acordo com as preferencias dos pecuaristas. O manejo de raleamento pode ser realizado em diferentes momentos à medida que as árvores crescem e interferem negativamente entre elas e com o capim. Uma possibilidade é selecionar apenas os maiores indivíduos para permanecer no sistema. Por exemplo, em um espaçamento final de 8 metros entre plantas, e 20 metros entre linhas, teria-se 90 indivíduos na área de estudo (1,3 ha). Se fossemos fazer hoje esta seleção dos 90 maiores indivíduos, eles teriam média de $63 \mathrm{~cm}$ de altura e contemplariam 5 espécies. Portanto, já estariam próximos a ultrapassar a altura do 
capim $^{20}$, fase mais crítica ao seu desenvolvimento por sofrer forte competição e estar mais vulnerável aos danos provocados pelo gado (PORFÍRIO-DA-SILVA, 2010).

O baixo crescimento da parte aérea nos primeiros anos é uma característica das espécies de cerrado sentido restrito, principalmente quando comparadas com espécies pioneiras de ambientes florestais (ARASAKI e FELIPPE, 1990; SILVA e CORREA, 2008; SILVA et al., 2015). O crescimento pode ter sido mais lento devido à forte competição com o capim adjacente, devido ao seu rápido crescimento e dificuldade de controlá-lo, o que gera grande demanda de mão de obra, e encarece as operações de manejo (PORFÍRIO-DA-SILVA, 2010; RIGINOS, 2009). A velocidade de crescimento das espécies arbóreas é um fator importante para compor SSP já que elas precisam atingir um porte mínimo para que o gado possa retornar ao pasto sem causar danos físicos que comprometam sua sobrevivência (PORFIRIO-SILVA, 2015). O crescimento vagaroso também faz com que os benefícios das árvores ao sistema seja lento.

As espécies do cerrado investem primeiramente no crescimento das raízes para alcançar umidade do solo em maior profundidade e armazenar energia para rebrotar após o fogo (HOFFMANN e FRANCO, 2003). Elas são adaptadas a solos ácidos e de baixa fertilidade (HARIDASAN, 2000). Apesar do crescimento lento, atendem outros critérios vantajosos para arborizar pastagens comparativamente a espécies florestais, como a adaptação ao ambiente (período de estiagem, solos ácidos e baixa fertilidade), resistência ao fogo, raízes profundas (buscam água em profundidade), alta capacidade de rebrotar após danos causados pelos animais, copas pouco densas e estreitas (para as duas últimas características ver capítulo 3) (CARVALHHO, 2001; PORFIRIO-SILVA, 2015; BAGGIO E CARPANEZZI, 1988).

\footnotetext{
${ }^{20}$ Porém pode ocorrer das árvores maiores estarem mal distribuídas, portanto, o posicionamento deve ser ponderado o que pode a diminuir a altura média.
} 
Possíveis soluções para lidar com o baixo crescimento das árvores nos SSP são o consórcio com espécies agrícolas anuais, de mais fácil manejo que o capim braquiária, durante os primeiros anos de implantação do sistema (PORFIRIO-DA-SILVA et al., 2009). Existem diversas experiências exitosas deste tipo de sistema, embora a maioria delas, com o uso de uma ou poucas espécies arbóreas (principalmente eucalipto) (GONTIJONETO et al., 2015). É viável consociar plantas agrícolas com o plantio de árvores (BRIENZA JUNIOR, 2011), principalmente em locais de menor precipitação, onde as espécies agrícolas podem favorecer as árvores (HOLMGREN, 1997). Mesmo em situações em que as plantas agrícolas não interferem no comportamento das plântulas de espécies arbóreas já é vantajoso, pois enquanto elas crescem a área continua gerando renda (SILVA et al., 2015). Proteção física das mudas, que neste caso, poderia ser feita com cerca elétrica, protegendo toda a linha de plantio (MELADO, 2002) ou com o uso de cercas vivas utilizando espécies forrageiras de rápido crescimento (VILLANUEVA, 2008). Em ambos os casos os custos e eficiência precisam ser avaliados. Outra alternativa é a entrada do gado com as árvores pequenas, antes do porte mínimo recomendado $(6 \mathrm{~cm}$ de diâmetro a altura do peito) PORFÍRIODA-SILVA et al., 2012), para testar a hipótese de que estas são mais rústicas, e por já possuírem raízes bem estabelecidas e alta capacidade de rebrota seriam capazes de tolerar possíveis danos causados pelos animais.

As espécies que apresentaram valores de germinação muito baixos, Tachigali subvelutina e Byrsonima verbascifolia, possuem dormência nas sementes, que não foram quebradas para plantio em campo. Para o carvoeiro, o teste de germinação em laboratório, com quebra de dormência por escarificação, obteve $55 \%$ de germinação, o que está e acordo com a literatura que cita percentuais entre 50 a 100\% (CARVALHO, 2003), portanto, valor bastante superior aos $7 \%$ apresentados no campo. Como as 
sementes apresentaram-se viáveis em laboratório, pressupõe-se que pode ter havido predação das mesmas no campo (HULME, 1998) ou uma emergência seguida de morte (por dessecação ou herbivoria), sem que este evento tenha sido diagnosticado devido ao intervalo entre as coletas de campo ser de um (01) mês. A dificuldade de germinação de Byrsonima verbascifolia está registrada na literatura, inclusive quando testados diferentes métodos de quebra de dormência (ALBERTO et al., 2011). Já Copaifera langsdorffii apresentou boa emergência, porém alta mortalidade que pode ser devido sua suscetibilidade às condições microclimáticas, competição com o capim e ataque de formigas. Alta mortalidade para a espécie também foi encontrada em Silva e colaboradores (2015), porém não se confirma em Pellizzaro (2016). Para estas três espécies sugere-se aumentar o número de espécies semeadas.

As dificuldades relatadas de incluir árvores em áreas de pastagens por meio de semeadura direta salientam a relevância e o potencial de manter as árvores nativas ainda remanescentes nas pastagens e manejar a regeneração natural de rebrotas do Cerrado, pois é um método barato de renovar as árvores na pastagem. A oportunidade de possuir estas árvores sem custos adicionais e ainda desfrutar das vantagens econômicas que elas podem oferecer precisa estar clara previamente à decisão de desmatamento e formas de manejo que cessem a regeneração natural da área. 


\section{REFERENCIAS BIBLIOGRAFICAS}

AGUIRRE, A. G. Potencial da semeadura direta na restauração florestal de pastagem abandonada no município de Piracaia, SP, Brasil. Hoehnea, v..42, n. 4, 2015.

ALBERTO, P. S. et al. Métodos para superação da dormência de sementes de murici (Byrsonima verbascifolia Rich). Semina: Ciências Agrárias, Londrina, v, 32, n. 3, p. 1015-1020, 2011

ALMEIDA, S. P. de.; et al. Cerrado: espécies vegetais úteis. EMBRAPA, DF, 1998, p. 464.

AlMEIDA, S. P.; COSTA, T. S. A.; SILVA, J. A. Frutas nativas do Cerrado: caracterização físico-químico e fonte potencial de nutrientes . 2008, 1279p. In: SANO, S. M.; ALMEIDA, S. P.; RIBEIRO, J. F. (eds.). Cerrado: ecologia e flora. EMBRAPA Informação Tecnologia, Brasília-DF.

ARASAKI, F. R. \& FELIPPE, G. M. Crescimento inicial de Kielmeyera coriacea. Ciência e Cultura, v. 42, p. 715-720, 1990

ARAKI, D. F. Avaliação da semeadura a lanço de espécies florestais nativas para recuperação de áreas degradadas. 2005. Dissertação de Mestrado, Universidade de São Paulo, Piracicaba. 2005.

BAGGIO, A. J.; CARPANEZZI, O. B. Alguns sistemas de arborização de pastagens. Boletim de Pesquisa Florestal, Curitiba, n. 17, p. 47-60, 1998

BARBOSA, L. M. et al. Recuperação florestal com espécies nativas no Estado de São Paulo: pesquisas apontam mudanças necessárias. Florestar Estatístico, v.6, p.28-34, 2003.

BASTOS, E.; BRANDÃO, M.; FERREIRA, J. A. Inventário da flora apícula do Município de Bom Jesus do Amparo, Minas Gerais - II. Daphne, Belo Horizonte, v. 3, n. 4, p. 21-31, out. 1993.

BASTOS, E. M.; et al. Inventário da flora apícola do Cerrado no Estado de Minas Gerais: I. Município de Cardeal Mota. Daphne, Belo Horizonte, v. 8, n. 3, p. 44-50, jul, 1998.

BASTOS, E. M.; et al. Inventário da flora apícola do Cerrado no Estado de Minas Gerais: I. Município de Cardeal Mota. Daphne, Belo Horizonte, v. 8, n. 3, p. 44-50, jul, 1998. 
BRANDÃO, M.; FERREIRA, F. B. D. Flora apícola do Cerrado. Informe Agropecuário, Belo Horizonte, v.15, n. 168, p. 5-7, 1991.

BRASIL, MINISTÉRIO DO MEIO AMBIENTE. Mapeamento do uso e cobertura da terra do Cerrado: Projeto TERRACLASS Cerrado 2013. Brasília, 2015, 69 p.

BRIENZA JÚNIOR, S. et al. Plantio de árvores de crescimento rápido para recuperação de áreas agrícolas na Amazônia Brasileira: estudo de caso com produção de milho e mandioca. Pesquisa Florestal Brasileira, v.31, n. 68, pg. 347-353, out/dez. 2011. BONILLA-MOHENO, M.; HOLL, K. D. Direct seeding to restore tropical matureforest species in areas of slashand-burn agriculture. Restoration Ecology v.18, p. 438$445,2010$.

CAMARGO, J. L. C., FERRAZ I. D. K., IMAKAWA, A. M. Rehabilitation of degraded areas of central Amazonia using direct sowing of forest tree seeds. Restoration Ecology, v. 10, p. 636-644. 2002.

CAMPOS FILHO, E. M.; SARTORELLI, P. A. R.; Guia de árvores com valor econômico. São Paulo: INPUT - AGROICONE. nov. 2015, v.1, p. 141.

CAMPOS-FILHO, E. M. et al. Mechanized direct-seeding of native forests in Xingu, Central Brazil. Journal of Sustainable Forestry, v. 32, p. 702-727. 2013.

CARVAlHO, M. M.; XAVIER, D. F.; ALVIM, M. J. Características de algumas leguminosas arbóreas adequadas para a associação com pastagens. Juiz de Fora: Embrapa Gado de Leite, 2001. 24 p. (Circular Técnica, 64).

CARVALHO, P. E. R. Espécies arbóreas Brasileiras. EMBRAPA Informação Tecnologia: Brasília - DF, 2003, v. 1, p. 435.

CARVALHO, P. E. R. Espécies arbóreas Brasileiras. EMBRAPA Informação Tecnologia: Brasília - DF, 2006, v. 2, p. 435.

CARVALHO, P. E. R. Espécies arbóreas Brasileiras. EMBRAPA Informação Tecnologia: Brasília - DF, 2014, v. 5, p. 435.

CASTRO, C. R. T; PACIULLO D. S. C. Boas práticas para a implantação de sistemas silvipastoris. Juiz de Fora: Embrapa Gado de Leite. 2006. (Comunicado Técnico, 50). CECCON, E.; GONZALEZ, E. J.; MARTORELL, C. Is Direct Seeding a Biologically Viable Strategy for Restoring Forest Ecosystems? Evidences from a Meta-analysis. Land Degradation e Development, v. 27, p. 511-520, 2016. 
COLE R. J., et al. Direct seeding of late-successional trees to restore tropical montane forest. Forest Ecology and Management, v. 261, p. 1590-1597, 2011

CORREA, M. P. Dicionário das plantas úteis do Brasil e das exóticas cultivadas. Rio de Janeiro: Ministério da Agricultura, v. 5, 1974.

DE ALMEIDA, S. P. ET AL. A gueroba (syagrus oleracea Becc.) nas comunidades rurais I: aproveitamento agroindustrial. Planaltina: Embrapa Cerrados, 2000, 37p.

DE ALMEIDA, D. et al. Plantas visitadas por abelhas e polinização. Piracicaba: ESALQ- Divisão de biblioteca e Documentação, 2003, 40p.

DIAS FILHO, M. B. Degradação de pastagens: processos, causas e estratégias de recuperação. Revista atual e ampliada, Belém, n. 4, p. 216, 2011.

DOUST, S. J., ERSKINE, P. D., LAMB, D. Direct seeding to restore rainforest species: Microsite effects on the early establishment and growth of rainforest tree seedlings on degraded land in the wet tropics of Australia. Forest Ecology and Management v. 234: p. 333-343, 2006.

DOUST, S. J., ERSKINE, P. D.; LAMB, D. Restoring rainforest species by direct seeding: tree seedling establishment and growth performance on degraded land in the wet tropics of Australia. Forest Ecology and Management. v. 256, p.1178-1188. 2008.

ENGEL V. L., PARROTTA J. A. An evaluation of direct seeding for reforestation of degraded lands in central Sao Paulo state, Brazil. Forest Ecology and Management v. 152 , p.169-181, 2001

FONSECA, C. E. L. et al. Recuperação da vegetação de matas de galeria: estudos de caso no Distrito Federal e entorno. In: RIBEIRO, J. F.; FONSECA, C.E.L. da; SOUZASILVA, J. C. (Eds.). Cerrado - caracterização e recuperação de matas de galeria. Planaltina: [s. n.], 2001. v. 1, p.815-867.

GONTIJO NETO, M. M. et al. Integração Lavoura-Pecuária Floresta em Minas Gerais. In: ALVES, F. V.; LAURA, V. A.; ALMEIDA, R. G. DE (Eds.). Sistemas Agroflorestais: A agropecuária sustetável. 1. ed. Brasília, DF: Embrapa, 2015. p. 29-43 RIBASKI, J., RIBASKI, S. G. Sistemas agroflorestais na região Sul do Brasil. In: ALVES, F. V.; LAURA, V. A.; ALMEIDA, R. G. DE (Eds.). Sistemas Agroflorestais: A agropecuária sustetável. 1. ed. Brasília, DF: Embrapa, 2015. p. 45-68. 
HARIDASAN, M. Nutrição mineral de plantas nativas do cerrado. Rev. Bras. Fisiol. Veg., v. 12, n. 1, p. 54-64, 2000.

HOFFMANN, W. A.; FRANCO, A. C. Comparative growth analysis of tropical forest and savanna woody plants using phylogenetically-independent contrasts. Journal of ecology. v. 91, n. 3, p. 475-484, 2003.

HOLMGREN, M.; SCHEFFER, M.; HUSTON, M. A. The interplay of facilitation and competition in plant communities. Ecology, v. 78, n. 7, p. 1966-1975, 1997.

HOOPER, E., CONDIT, R., LEGENDRE, P., Responses of 20 native tree species to reforestation strategies for abandoned farmland in Panama. Journal of Applied Ecology. 12, 1626-1641, 2002.

HULME, P. E. Post-dispersal seed predation: consequences for plant demography and evolution. Perspectives in Plant Ecology, Evolution and Systematics, v.1, p.32-46, 1998.

IBGE - Instituto Brasileiro de Geografia e Estatística. Anuário Estatístico do Brasil. Rio de Janeiro: v. 75. 2015, 456p.

IBGE. Árvores do Brasil Central: espécies da região geoeconômica de Brasília. Rio de Janeiro, 2002. v.1, p. 417.

INMET - Instituto Nacional de Meteorologia. Banco de dados Metereológicos para Ensino e Pesquisa - BDMEP. Disponível em http://www.inmet.gov.br/portal/index.php?r=bdmep/bdmep>. Acesso em março de 2017.

JENRICH, H. Vegetação arbórea e arbustiva nos altiplanos das chapadas do Piauí central: características, ocorrência e empregos. Teresina: GTZ, 1989. 70 p.

LIMA, I. L. P.. Manejo de produtos florestais por agricultores tradicionais visando o enriquecimento de uma paisagem de Cerrado no norte de Minas Gerais. 141f. tese (doutorado em Ecologia) - Instituto de Ciências Biológicas, Universidade de Brasília, Brasília, 2016.

LORENZI, H. Árvores brasileiras: Manuel de identificação e cultivo de plantas arbóreas do Brasil. Nova Odessa. São Paulo: Instituto Plantarum, 2000, 4º ed., v.1, , p. 368.

MAINIERI, Calvino; CHIMELO, Joao Peres. Fichas de caracteristicas das madeiras brasileiras. 2. ed. São Paulo: Instituto de Pesquisas Tecnológicas do Estado de São Paulo, 1989. $418 \mathrm{p}$. 
MELADO, J. Pastagens ecológicas: o habitat natural do bovino orgânico. Conferência Virtual Global sobre Produção Orgânica de Bovinos de Corte, Universidade do Contestado (ed), Concordia - SC e Embrapa Pantanal - Corumbá - MS, nov, 2002.

MONTOYA VILCAHUAMAN, L. J.; BAGGIO, A. J. Guia prático sobre arborização de pastagens. Colombo-PR: Embrapa Florestas, 2000. 16p. (Embrapa Florestas. Documentos, 49).

NASCENTE, S. N., PEIXOTO, N., DOS SANTOS, C. W. F. Peso de sementes e emergência de Plântulas de guariroba (Syagrus oleracea Becc). Pesquisa Agropecuária Tropical, v.30, n. 2, p.77-79, jun/dez 2000

OLIVEIRA-FILHO, A. T. Estudos ecológicos da vegetação como subsídios para programas de revegetação com espécies nativas: uma proposta metodológica. Revista Cerne, Lavras, v.1, n.1, p.64-72, jan./dez. 1994.

PALMA, A. C.; .LAURANCE, S. G. W. A review of the use of direct seeding and seedling plantings in restoration: what do we know and where should we go? Applied Vegetation Science, v. 18, p. 561-568, 2015

PELLIZZARO, K. F.. Restauração ecológica por meio de semeadura direta no Cerrado: avaliando espécies de diferentes formas de vida e densidades de plantio. 2016. 75 f., Dissertação (Mestrado em Ecologia)—Universidade de Brasília, Brasília, 2016.

PORFÍRIO-DA-SILVA, V.; MEDRADO, M. J. S.; NICODEMO, M. L. F.; DERETI, R. M. Arborização de pastagens com espécies florestais madeireiras: implantação e manejo. Colombo: Embrapa Florestas, 2009. 48p.

PORFÍRIO-DA-SILVA, V. et al. Danos causados por bovinos em diferentes espé- cies arbóreas recomendadas para sistemas silvipastoris. Pesquisa Florestal Brasileira, v.32, n.70, p. 67-76, abr/jun. 2012

PORFÍRIO-DA-SILVA, V. Ideótipo de espécie arbórea para Sistemas de Integração Lavoura-Pecuária-Floresta. In: LAURA, V. A., ALVES, F. V., ALMEIDA, R. G. Sistemas agroflorestais: a agropecuária sustentável, Brasília : Embrapa, 2015. 208 p. POTT, A.; POTT, V. J. Inventário da flora apícola do pantanal em Mato Grosso do Sul. Corumbá, MS: EMBRAPA-CPAP, 1986. 16 p. (EMBRAPA-CPAP. Pesquisa em andamento, 3) 
POTT, A.; POTT, V. J. Plantas Nativas potenciais para sistemas agroflorestais em Mato Grosso do Sul. In: SEMINÁRIO SISTEMAS AGROFLORESTAIS E DESENVOLVIMENTO SUSTENTÁVEL, 2003, Campo Grande. Anais: Campo Grande: Embrapa, 2003.

REATTO et al. Levantamento semidetalhado dos solos da Bacia do rio Jardim-DF, escala 1:50.000. Planaltina : Embrapa Cerrados, 2000. 63p.

RIGINOS, C. Grass competition suppresses savanna tree growth across multiple demographic stages. Ecology, v. 90, n. 2, p. 335-340, 2009.

RIZZINI, C. T.; MORS, W. B. Botânica econômica brasileira. São Paulo, EPU, Ed. da Universidade de São Paulo, 1976. p.206.

SAlOMÃO, A. N. et al. Germinação de Sementes E Produção de Mudas de Plantas Do Cerrado. Brasília, DF: Rede de Sementes do Cerrado. 2003.

SANTOS, S. A.; et al. Grau de Preferência e Índice de Valor Forrageiro das Pastagens Nativas Consumidas por Bovinos no Pantanal. Corumbá, MS 2003. EMBRAPA: Boletim de Pesquisa e Desenvolvimento 49

SASSAKI, R. M.; FELIPPE, G. M. Remoção dos cotilédones e desenvolvimento inicial de Dalbergia miscolobium. Revista Brasileira de Botânica, v. 15, p. 5-16, 1992

SHANLEY, P., SERRA, M., MEDINA, G. (ed.) Frutíferas e plantas úteis na vida amazônica. CIFOR, 2010, 320p.

SILVA, J. C. (Ed.). Caracterização e recuperação de matas de galeria. Planaltina: Embrapa Cerrados. 2001. p.815-870.

SILVA-JUNIOR, M. C. 100 Árvores do Cerrado sentido restrito: guia de campo. Brasília: Rede de Sementes do Cerrado, 2012, 304p.

SILVA, R. R. P. et al., Direct seeding of Brazilian savanna trees: effects of plant cover and fertilization on seedling establishment and growth. Restoration Ecology. 23, n.4, p.393-401, 2015

SILVA, L. C. R; CORRÊA, R. S. Sobrevivência e crescimento de seis espécies arbóreas submetidas a quatro tratamentos em área minerada no cerrado. Rev. Árvore, ViçosaMG, v.32, n.4, p.731-740, 2008 
SUN, D.; DICKINSON, G. R.. The competition effect of Brachiaria decumbens on the early growth of direct-seeded trees of Alphitonia petriei in tropical north Australia.

Biotropica v. 28. p. 272-276. 1996

VIEIRA, R. F.; et al. Frutas nativas da região Centro-Oeste do Brasil. Brasília, DF, EMBRAPA Informação Tecnológica , 2010. 322 p.: il.

VILLANUEVA, C.; IBRAHIM, M.; CASASOLA, F. Valor economico y ecológico de las cercas vivas en fincas y paisajes ganaderos, 1ed. Turrialba, Costa Rica: CATIE, 2008 


\section{CONSIDERAÇÕES FINAIS}

O tema abordado é de grande relevância, pois trata da pecuária, principal atividade de uso do solo do Planeta e também do Cerrado. Bioma este reconhecido como um hotspot mundial, e a pecuária conhecida por sua grande "pegada" ambiental. Em um momento histórico que as questões ambientais estão em foco e mobilizam a sociedade global, falar da possibilidade de fazer pecuária no Cerrado capaz de gerar serviços ambientais, com conservação da biodiversidade local, parece demandar uma nova e grandiosa tecnologia. Mas não necessariamente, talvez perpasse em reconhecer e valorizar tecnologias e conhecimentos locais que vem sendo desenvolvidos e aperfeiçoados ao longo do tempo, porém, ignorados e por vezes desvalorizados.

Pecuaristas no Cerrado que possuem SSP com árvores nativas estão conservando a biodiversidade, muitas vezes, além do exigido por lei, já que as áreas de estudo não estavam, segundo dados dos entrevistados, em Áreas de Preservação Permanente, nem de Reserva Legal. Portanto, muitos proprietários ainda possuem o direito de retirar diversas árvores das suas pastagens, logo, torna-se essencial valorizar e fomentar este tipo de sistema, já que ele traz benefícios locais e para toda sociedade. Esta valorização seria uma maneira de incentivar estes pecuaristas a não mudar de ideia e seguir firme aperfeiçoando este tipo de sistema. Mecanismos de pagamento por serviços ambientais podem ter um papel importante.

Novos estudos com o mesmo enfoque são indicados em outras partes do Cerrado que ajudarão a abastecer um banco de dados para compreender a temática de forma mais global. Esclarecer como as características e arranjos destes sistemas podem estar relacionadas a fatores ambientais, como a precipitação por exemplo, e às características socioeconômicas dos pecuaristas, bem como aos tipos de criação e manejo adotados, às espécies de gramíneas. Também é importante compreender a dinâmica destes sistemas ao longo do tempo na escala da paisagem por meio de análises que envolvam geoprocessamento. Propor melhorias e inovações a estes sistemas é desejável, porém, demanda a compreensão aprofundada dos mesmos, inclusive em relação a seus parâmetros produtivos.

Diversos setores da sociedade como a academia, as instituições de ensino, os profissionais de assistência técnica, os formuladores de políticas publicas, precisam 
reconhecer a existência (e sobrevivência) dos sistemas silvipastoris com árvores nativas no Cerrado e agirem de forma conjunta para fortalecer os sistemas existentes e pensar em futuros SSP com características similares. Colocar em diálogo o conhecimento científico e o conhecimento dos pecuaristas que aprendem cotidianamente por meio experimentações e observações atentas do ambiente, pode gerar sinergias que contribuam para aperfeiçoar um modelo de produção compatível com a biodiversidade do Cerrado. Assim, será possível avançar rumo a modelos de agricultura sustentável que compatibilizem a produção com conservação.

Ao longo da pesquisa, questões que podem ser úteis a este tipo de sistema foram diagnosticadas como ainda pouco exploradas nos locais estudados. Como exemplo, o uso de cercas vivas, inclusive para formar piquetes com menor custo, produzir forragem e poupar árvores estabelecidas nas pastagens; o manejo das árvores incluindo práticas de poda para adequar sua arquitetura em benefício do sistema; o esclarecimento sobre a legalidade e o potencial de uso das madeiras dentro das pastagens, baseado em um manejo sustentável, que aproveita e conduz as regenerantes, sem comprometer os benefícios da arborização destas pastagens; a capacitação e divulgação de técnicas praticadas por Jurandir Melado ${ }^{21}$ na formação e manejo deste tipo de sistema, baseado no pastoreio rotacional VOSIN, tecnologia adaptada a biodiversidade do Cerrado, que inova ao formar as pastagens com gramíneas exóticas mantendo grande quantidade de árvores sem danificar o solo com a entrada de maquinário. Todas questões acima merecem ser estudadas e podem ser úteis ao futuro dos SSPs no Cerrado.

\footnotetext{
${ }^{21}$ Mais detalhes em http://www.fazendaecologica.com.br/pastagem_ecologica
} 


\section{ANEXO 1}

\section{Roteiro da entrevista semi estruturada}

Dados gerais:

- Nome da fazenda, chácara, assentamento:

- Localização

- Nome do entrevistado

- Desde quando possui a propriedade

- Tamanho da propriedade

- Tamanho da área com pastagem arborizada

- Quando foram formadas

- Espécie de capim

- Raça do animal

- Objetivo da criação do gado? (leite, corte, recria, aluga pasto...)

- Quantidade total de animais? lotação por ha (carga animal)

- Histórico de uso da área

\section{Questões norteadoras:}

\section{Motivações, potencialidades, desafios}

- Por que decidiu formar a pastagem mantendo estas árvore? Percebe vantagens? Quais?

- Quais as dificuldades ou desafios desta técnica?

\section{Compreensão da técnica e seu embasamento, da formação ao manejo}

- Como foi feita a escolhas das arvores para serem deixadas na pastagem? Por quê? (espécies, porte, posicionamento das árvores).

- A quantidade de árvores que tem hoje na sua pastagem você acha que é ideal, ou poderia ter mais ou menos?

- São realizadas podas nas árvores que ficam? Com que frequência? Como?

- Como é feito o manejo das rebrotas ("Limpeza”)? com que frequência? Quando? Equipamentos?

- No momento da limpeza deixa ficar algumas rebrotas? Que quantidade? Como seleciona?

- Estas rebrotas trazem algum benefícios ou era preferível que não rebrotassem mais?

- Estas rebrotas influenciam o capim? Por que?

- Percebe se o gado tem preferência pela sombra de determinada espécie? Por quê?

- Percebe se o capim fica mais bonito próximo a determinada espécies? Por quê?

- Já percebeu algum efeito tóxico destas árvores para os animais?

- Alguma espécie de árvore após a formação do pasto se espalha muito e chega a ser problema? Qual?

- Alguma espécie após formação do pasto sofre muito com o vento? Chega a morrer?

Principais produtos úteis 
- As árvores geram alimentos para os animais (folhas, flores, frutos)? Quais? Qual a importância disso em termos quantidade e qualidade?

- Você consome ou comercializa algum fruto das espécies nativas que estão na pastagem. Quais?

- Utiliza as árvores para algum outro uso (medicinal, artesanato)? Quais?

- Utiliza a madeira na propriedade numa necessidade? Quais? Para quê?

- Cite três espécies que você considera as melhores para ter nas pastagens. 


\section{ANEXO 2:}

Tabela com listagem das Famílias e espécies de árvores nativas encontradas no estudo de 47 pastagens arborizadas( 1 ha) na área central do Cerrado.

\section{Famílias/Espécies}

\section{Anacardiaceae}

Anacardium humile A.St.-Hil.

Astronium fraxinifolium Schott

Myracrodruon urundeuva Allemão

Tapirira guianensis Aubl.

\section{Annonaceae}

Annona coriacea Mart.

Annona crassiflora Mart.

Xylopia aromatica (Lam.) Mart.

\section{Apocynaceae}

Aspidosperma cuspa (Kunth) S.F.Blake ex Pittier

Aspidosperma macrocarpon Mart.

Aspidosperma sp.

Aspidosperma subincanum Mart. ex A.DC.

Aspidosperma tomentosum Mart.

Himatanthus obovatus (M.Arg.)Woods

Himathantus glomerulatus Less.

\section{Araliaceae}

Schefflera macrocarpa

Schefflera spl

\section{Arecaceae}

Acrocomia aculeata (Jacq.) Lodd. ex Mart.

Attalea speciosa Mart.

Syagrus cearensis Noblick

Syagrus oleracea (Mart.) Becc.

\section{Asteraceae}

Piptocarpha rotundifolia (Less.) Baker

\section{Bignoniaceae}

Cybistax antisyphilitica (Mart.) Mart.

Handroanthus impetiginosus (Mart. ex DC.) Mattos

Handroanthus ochraceus (Cham.) Mattos

Handroanthus serratifolius (A.H.Gentry) S.Grose

Jacaranda brasiliana (Lam.) Pers.

Tabebuia aurea (Silva Manso) Benth. \& Hook.f. ex S.Moore

Tabebuia roseoalba (Ridl.) Sandwith

\section{Boraginaceae}

Cordia glabrata (Mart.) A.DC.

Cordia trichotoma (Vell.) Arráb. ex Steud.

\section{Burseraceae}

Protium heptaphyllum (Aubl.) Marchand

Tetragastris altissima (Aubl.) Swart 


\section{Calophyllaceae}

Kielmeyera speciosa St. Hil.

Kielmeyera coriacea Mart. \& Zucc.

\section{Caryocaraceae}

Caryocar brasiliense Camb.

\section{Celastraceae}

Plenckia populnea

Salacia crassiflora

Chrysobalanaceae

Licania sp1

\section{Combretaceae}

Buchenavia grandis Ducke

Buchenavia tomentosa Eichler

Terminalia argentea Mart.

Terminalia fagifolia Mart.

terminália $s p$

\section{Connaraceae}

Connarus suberosus Planch.

\section{Dilleniaceae}

Curatella americana $L$.

Davilla eliptica

\section{Ebenaceae}

Diospyros burchellii Hiern

\section{Erythroxylaceae}

Erythroxylum deciduum A.St.-Hil.

Erythroxylum sp1

Erythroxylum sp2

Erythroxylum suberosum A.St.-Hil.

Erythroxylum tortuosum Mart.

\section{Fabaceae}

Acacia farnesiana (L.)Willd.

Acacia glomerosa Benth.

Amburana cearensis (Allemão) A.C.Sm.

Anadenanthera colubrina (Vell.) Brenan

Anadenanthera peregrina (L.) Speg.

Andira vermifuga (Mart.) Benth.

Bauhinia rufa (Bong.) Steud.

Bowdichia virgilioides Kunth.

Chloroleucon tortum (Mart.) Pittier

Copaifera langsdorffii Desf.

Dalbergia miscolobium Benth.

Dimorphandra mollis Benth.

Dipteryx alata Vogel

Enterolobium contortisiliquum (Vell.) Moronga

Enterolobium gummiferum (Mart.) J.F.Macbr

Fabaceae 
Hymenaea courbaril L.

Hymenaea stigonocarpa Mart. ex Hayne

Inga sp.

Leptolobium dasycarpum Vogel

Luetzelburgia auriculata (Allemao) Ducke

Machaerium acutifolium Vogel

Machaerium hirtum (Vell.) Stellfeld

Machaerium opacum Vogel

Machaerium sp.

Machaerium stipitatum (DC.) Vogel

Plathymenia reticulata Benth.

Pterodon sp

Stryphnodendron adstringens (Mart.) Coville

Stryphnodendron polyphyllum Mart.

Tachigali aurea Tul.

Tachigali paniculata Aubl.

Vatairea macrocarpa (Benth.) Ducke

\section{Icacinaceae}

Emmotum nitens (Benth.) Miers

\section{Indeterminada 1}

Indet 1

\section{Lamiaceae}

Hyptidendron sp1

\section{Loganiaceae}

Strychnos pseudoquina

\section{Lythraceae}

Lafoensia pacari A.St.-Hil.

Physocalymma scaberrimum Pohl

\section{Malpighiaceae}

Byrsonima coccolobifolia

Byrsonima crassifolia (L.) Kunth

Byrsonima pachyphylla A.Juss.

Byrsonima verbascifolia (L.) DC.

Malpiguiaceae 2

\section{Malvaceae}

\section{Eriotheca gracilipes}

Eriotheca pubescens (Mart. \& Zucc.) Schott \& Endl.

Guazuma ulmifolia Lam.

Luehea candicans

Luehea divaricata Mart.

Luehea paniculata Mart. \& Zucc.

Luehea speciosa Willd

Pseudobombax longiflorum (Mart. \& Zucc.) A. Robyns

Pseudobombax tomentosum (Mart. \& Zucc.) A.Robyns

Sterculia striata A.St.-Hil. \& Naudin

\section{Melastomataceae}


Miconia albicans (Sw.) Triana

\section{Moraceae}

Brosimum gaudichaudii Trécul

Ficus enormis Mart. ex Miq.

\section{Myrtaceae}

Eugenia dysenterica DC.

Psidium myrsinites DC.

Psidium sp.

\section{Nyctaginaceae}

Guapira noxia

Neea theifera Oerst.

\section{Ochnaceae}

Ouratea hexasperma

\section{Opiliaceae}

Agonandra brasiliensis Miers ex Benth. \& Hook.f.

\section{Polygonaceae}

Triplaris gardneriana Wedd.

\section{Proteaceae}

Roupala montana Aubl.

Rourea induta

\section{Rubiaceae}

Alibertia edulis (Rich.) A.Rich.

Genipa americana $L$.

Simira sp.

Tocoyena formosa (Cham. \& Schltdl.) K.Schum.

\section{Rutaceae}

Zanthoxylum rhoifolium Lam.

Zanthoxylum riedelianum Engl.

\section{Sapindaceae}

Dilodendron bipinnatum Radlk.

Magonia pubescens A.St.-Hil.

Matayba guianensis Aubl.

Sapindacea

Talisia esculenta (A. St.-Hil.) Radlk.

Sapotaceae

Pouteria ramiflora (Mart.) Radlk.

Pouteria torta

Simaroubaceae

Simarouba versicolor A. St.-Hil.

\section{Solanaceae}

Solanum lycocarpum A.St.-Hil

\section{Styracaceae}

Styrax ferrugineus

\section{Urticaceae}

Cecropia pachystachya Trécul

Vochysiaceae 
Callisthene fasciculata Mart.

Qualea grandiflora Mart.

Qualea multiflora Mart.

Qualea parviflora Mart.

Salvertia convallariodora A.St.-Hil. 


\section{ANEXO 3}

Tabela com os parâmetros fitossociológicos de espécies arbóreas encontradas em 47 pastagens arborizadas de 1 ha no Cerrado. Valores decrescentes de IVI (Índice de Valor de Importância), onde: $\mathrm{DR}=$ densidade relativa $(\%), \mathrm{FR}=$ frequência relativa (\%),DoR = dominância relativa $(\%)$.

\section{Espécie}

Caryocar brasiliense

Pterodon sp

Bowdichia virgilioides

Dipteryx alata

Eugenia dysenterica

Qualea grandiflora

Magonia pubescens.

Astronium fraxinifolium

Hymenaea stigonocarpa

Curatella americana

Terminalia argentea

Annona crassiflora

Qualea parviflora

Machaerium opacum

Myracrodruon urundeuva

Copaifera langsdorffii

Eriotheca gracilipes

Tabebuia aurea

Eriotheca pubescens

Plathymenia reticulata

Andira vermifuga

Leptolobium dasycarpum

Simarouba versicolor

Tachigali paniculata

Callisthene fasciculata

Roupala montana

Lafoensia pacari

Dalbergia miscolobium

Dimorphandra mollis

Qualea multiflora

Aspidosperma tomentosum

Xylopia aromatica

Cordia glabrata

Machaerium acutifolium

Handroanthus ochraceus

Acrocomia aculeata

Luehea paniculata

Anacardium humile

Zanthoxylum rhoifolium

$\begin{array}{rrrr}\text { DoF } & \text { DR } & \text { FR } & \text { IVI } \\ 15,5 & 12,0 & 3,8 & 31,4 \\ 10,5 & 3,8 & 3,2 & 17,5 \\ 5,6 & 6,2 & 3,6 & 15,4 \\ 6,1 & 5,3 & 3,2 & 14,7 \\ 6,0 & 3,9 & 3,4 & 13,3 \\ 2,9 & 6,7 & 2,9 & 12,6 \\ 4,2 & 4,1 & 2,9 & 11,2 \\ 3,2 & 3,7 & 3,3 & 10,2 \\ 2,7 & 3,4 & 3,3 & 9,5 \\ 3,7 & 2,6 & 2,7 & 9,0 \\ 3,0 & 2,8 & 2,8 & 8,6 \\ 2,4 & 2,9 & 2,4 & 7,7 \\ 1,8 & 2,6 & 2,7 & 7,1 \\ 1,2 & 3,3 & 1,9 & 6,4 \\ 2,4 & 1,5 & 1,8 & 5,7 \\ 2,8 & 0,6 & 1,5 & 4,9 \\ 0,4 & 3,5 & 0,3 & 4,2 \\ 1,0 & 1,2 & 1,9 & 4,0 \\ 1,6 & 0,8 & 1,2 & 3,7 \\ 0,9 & 0,9 & 1,6 & 3,4 \\ 0,8 & 1,0 & 1,5 & 3,4 \\ 0,3 & 2,2 & 0,8 & 3,3 \\ 0,7 & 0,8 & 1,6 & 3,1 \\ 1,0 & 0,7 & 1,4 & 3,1 \\ 0,8 & 0,6 & 1,6 & 3,0 \\ 0,7 & 1,0 & 1,0 & 2,7 \\ 0,1 & 1,0 & 1,4 & 2,6 \\ 0,8 & 1,3 & 0,5 & 2,6 \\ 0,3 & 0,6 & 1,4 & 2,3 \\ 0,2 & 0,6 & 1,4 & 2,2 \\ 0,3 & 0,7 & 1,1 & 2,1 \\ 0,3 & 0,6 & 1,2 & 2,1 \\ 0,3 & 0,4 & 1,2 & 1,9 \\ 0,4 & 0,3 & 1,1 & 1,8 \\ 0,2 & 0,6 & 1,0 & 1,8 \\ 0,3 & 0,4 & 1,0 & 1,6 \\ 0,4 & 0,3 & 0,8 & 1,5 \\ 0,4 & 0,4 & 0,7 & 1,5 \\ 0,2 & 0,4 & 0,8 & 1,5\end{array}$


Emmotum nitens

Stryphnodendron adstringens

Physocalymma scaberrimum

Pseudobombax tomentosum

Guapira noxia

Pouteria ramiflora

Hymenaea courbaril

Buchenavia grandis

Buchenavia tomentosa

Tapirira guianensis

Connarus suberosus

Salvertia convallariodora

Tachigali aurea

Handroanthus serratifolius

Byrsonima pachyphylla

Neea theifera Oerst.

Brosimum gaudichaudii Trécul

Vatairea macrocarpa

Byrsonima verbascifolia

Aspidosperma subincanum

Piptocarpha rotundifolia

Alibertia edulis

Machaerium stipitatum

Aspidosperma macrocarpon

Agonandra brasiliensis

Hyptidendron spl

Psidium myrsinites

Syagrus cearensis

Pseudobombax longiflorum

Luetzelburgia auriculata

Terminalia fagifolia

Annona coriacea

Schefflera macrocarpa

Enterolobium gummiferum

Strychnos pseudoquina

Luehea speciosa

Erythroxylum deciduum

$\mathrm{NiO1}$

Erythroxylum suberosum

Byrsonima coccolobifolia

Stryphnodendron polyphyllum

Diospyros burchellii

Matayba guianensis

Aspidosperma sp.

Syagrus oleracea

Dilodendron bipinnatum $\begin{array}{llll}1,3 & 0,2 & 0,0 & 1,4\end{array}$

$\begin{array}{llll}0,1 & 0,7 & 0,6 & 1,4\end{array}$

$0,6 \quad 0,6 \quad 0,2 \quad 1,4$

$\begin{array}{llll}0,5 & 0,2 & 0,7 & 1,4\end{array}$

$\begin{array}{llll}0,1 & 0,9 & 0,3 & 1,3\end{array}$

$\begin{array}{llll}0,3 & 0,3 & 0,7 & 1,3\end{array}$

$0,5 \quad 0,2 \quad 0,6 \quad 1,3$

$\begin{array}{llll}0,6 & 0,4 & 0,2 & 1,3\end{array}$

$\begin{array}{llll}0,2 & 0,3 & 0,8 & 1,3\end{array}$

$0,5 \quad 0,1 \quad 0,5 \quad 1,1$

$\begin{array}{llll}0,0 & 0,3 & 0,7 & 1,1\end{array}$

$0,3 \quad 0,2 \quad 0,6 \quad 1,1$

$0,1 \quad 0,2 \quad 0,7 \quad 1,1$

$0,2 \quad 0,2 \quad 0,6 \quad 1,0$

$0,1 \quad 0,2 \quad 0,6 \quad 0,9$

$\begin{array}{llll}0,0 & 0,2 & 0,7 & 0,9\end{array}$

$\begin{array}{llll}0,1 & 0,2 & 0,6 & 0,9\end{array}$

$\begin{array}{llll}0,1 & 0,2 & 0,6 & 0,9\end{array}$

$\begin{array}{llll}0,1 & 0,2 & 0,6 & 0,9\end{array}$

$\begin{array}{llll}0,2 & 0,2 & 0,5 & 0,9\end{array}$

$\begin{array}{llll}0,5 & 0,2 & 0,1 & 0,8\end{array}$

$\begin{array}{llll}0,1 & 0,1 & 0,5 & 0,8\end{array}$

$\begin{array}{llll}0,2 & 0,2 & 0,3 & 0,7\end{array}$

$\begin{array}{llll}0,1 & 0,1 & 0,5 & 0,7\end{array}$

$\begin{array}{llll}0,1 & 0,2 & 0,4 & 0,7\end{array}$

$\begin{array}{llll}0,1 & 0,4 & 0,2 & 0,7\end{array}$

$\begin{array}{llll}0,0 & 0,2 & 0,4 & 0,7\end{array}$

$\begin{array}{llll}0,1 & 0,1 & 0,4 & 0,6\end{array}$

$0,3 \quad 0,1 \quad 0,2 \quad 0,6$

$\begin{array}{llll}0,1 & 0,3 & 0,2 & 0,6\end{array}$

$\begin{array}{llll}0,3 & 0,1 & 0,2 & 0,6\end{array}$

$0,1 \quad 0,2 \quad 0,3 \quad 0,6$

$\begin{array}{llll}0,1 & 0,2 & 0,3 & 0,6\end{array}$

$\begin{array}{llll}0,0 & 0,1 & 0,4 & 0,6\end{array}$

$\begin{array}{llll}0,0 & 0,2 & 0,3 & 0,6\end{array}$

$0,2 \quad 0,1 \quad 0,2 \quad 0,5$

$\begin{array}{llll}0,0 & 0,1 & 0,3 & 0,5\end{array}$

$\begin{array}{llll}0,2 & 0,1 & 0,2 & 0,4\end{array}$

$\begin{array}{llll}0,1 & 0,1 & 0,3 & 0,4\end{array}$

$\begin{array}{llll}0,0 & 0,1 & 0,3 & 0,4\end{array}$

$\begin{array}{llll}0,1 & 0,1 & 0,3 & 0,4\end{array}$

$\begin{array}{llll}0,0 & 0,1 & 0,3 & 0,4\end{array}$

$0,1 \quad 0,1 \quad 0,2 \quad 0,4$

$\begin{array}{llll}0,1 & 0,1 & 0,2 & 0,4\end{array}$

$\begin{array}{llll}0,1 & 0,1 & 0,2 & 0,4\end{array}$

$\begin{array}{llll}0,2 & 0,1 & 0,1 & 0,3\end{array}$ 
Anadenanthera peregrina

Amburana cearensis

Jacaranda brasiliana

Cecropia pachystachya

Sapindacea

Plenckia populnea

Guazuma ulmifolia

Miconia albicans

Tabebuia roseoalba

Cybistax antisyphilitica

Byrsonima crassifolia

Protium heptaphyllum

Erythroxylum sp2

Pouteria torta

Attalea speciosa

Genipa americana

Anadenanthera colubrina

Tetragastris altissima

Solanum lycocarpum

Fabaceae

Machaerium sp.

Salacia crassiflora

Psidium sp.

Talisia esculenta

Luehea divaricata

Acacia glomerosa

Luehea candicans

Himathantusglomerulatus

Tocoyena formosa

Machaerium hirtum

Sterculia striata

Enterolobium contortisiliquum

Inga sp.

Chloroleucon tortum

Erythroxylum tortuosum

Ficus enormis

Zanthoxylum riedelianum

Triplaris gardneriana

Acacia farnesiana

Kielmeyera coriacea

Licania sp1

Erythroxylum spl

Davilla eliptica

Rourea induta

Malpiguiaceae 2

Kielmeyera speciosa $\begin{array}{llll}0,2 & 0,0 & 0,1 & 0,3\end{array}$

$\begin{array}{llll}0,1 & 0,1 & 0,2 & 0,3\end{array}$

$\begin{array}{llll}0,0 & 0,1 & 0,2 & 0,3\end{array}$

$\begin{array}{llll}0,0 & 0,1 & 0,2 & 0,3\end{array}$

$\begin{array}{llll}0,1 & 0,1 & 0,1 & 0,3\end{array}$

$\begin{array}{llll}0,0 & 0,2 & 0,1 & 0,3\end{array}$

$\begin{array}{llll}0,0 & 0,1 & 0,2 & 0,3\end{array}$

$0,0 \quad 0,1 \quad 0,2 \quad 0,3$

$\begin{array}{llll}0,0 & 0,1 & 0,2 & 0,3\end{array}$

$\begin{array}{llll}0,0 & 0,1 & 0,2 & 0,3\end{array}$

$\begin{array}{llll}0,0 & 0,1 & 0,2 & 0,3\end{array}$

$\begin{array}{llll}0,0 & 0,1 & 0,2 & 0,3\end{array}$

$\begin{array}{llll}0,0 & 0,1 & 0,2 & 0,3\end{array}$

$0,0 \quad 0,1 \quad 0,1 \quad 0,2$

$\begin{array}{llll}0,0 & 0,1 & 0,1 & 0,2\end{array}$

$0,1 \quad 0,1 \quad 0,1 \quad 0,2$

$0,1 \quad 0,0 \quad 0,1 \quad 0,2$

$0,1 \quad 0,0 \quad 0,1 \quad 0,2$

$0,0 \quad 0,1 \quad 0,1 \quad 0,2$

$\begin{array}{llll}0,0 & 0,1 & 0,1 & 0,2\end{array}$

$0,1 \quad 0,0 \quad 0,1 \quad 0,2$

$\begin{array}{llll}0,0 & 0,1 & 0,1 & 0,2\end{array}$

$\begin{array}{llll}0,0 & 0,0 & 0,1 & 0,2\end{array}$

$\begin{array}{llll}0,0 & 0,0 & 0,1 & 0,2\end{array}$

$\begin{array}{llll}0,0 & 0,0 & 0,1 & 0,2\end{array}$

$\begin{array}{llll}0,0 & 0,1 & 0,1 & 0,2\end{array}$

$\begin{array}{llll}0,0 & 0,1 & 0,1 & 0,2\end{array}$

$\begin{array}{llll}0,0 & 0,0 & 0,1 & 0,2\end{array}$

$\begin{array}{llll}0,0 & 0,0 & 0,1 & 0,2\end{array}$

$\begin{array}{llll}0,0 & 0,0 & 0,1 & 0,2\end{array}$

$0,0 \quad 0,0 \quad 0,1 \quad 0,1$

$0,0 \quad 0,0 \quad 0,1 \quad 0,1$

$0,0 \quad 0,0 \quad 0,1 \quad 0,1$

$0,0 \quad 0,0 \quad 0,1 \quad 0,1$

$0,0 \quad 0,0 \quad 0,1 \quad 0,1$

$0,0 \quad 0,0 \quad 0,1 \quad 0,1$

$0,0 \quad 0,0 \quad 0,1 \quad 0,1$

$0,0 \quad 0,0 \quad 0,1 \quad 0,1$

$\begin{array}{llll}0,0 & 0,0 & 0,1 & 0,1\end{array}$

$\begin{array}{llll}0,0 & 0,0 & 0,1 & 0,1\end{array}$

$0,0 \quad 0,0 \quad 0,1 \quad 0,1$

$\begin{array}{llll}0,0 & 0,0 & 0,1 & 0,1\end{array}$

$0,0 \quad 0,0 \quad 0,1 \quad 0,1$

$0,0 \quad 0,0 \quad 0,1 \quad 0,1$

$\begin{array}{llll}0,0 & 0,0 & 0,1 & 0,1\end{array}$

$0,0 \quad 0,0 \quad 0,1 \quad 0,1$ 
Schefflera sp1

Styrax ferrugineus

Bauhinia rufa

Himatanthus obovatus

Handroanthus impetiginosus

Aspidosperma cuspa

Indet 1

Ouratea hexasperma

Cordia trichotoma

Terminalia sp.

Simira sp.

$\begin{array}{llll}0,0 & 0,0 & 0,1 & 0,1 \\ 0,0 & 0,0 & 0,1 & 0,1 \\ 0,0 & 0,0 & 0,1 & 0,1 \\ 0,0 & 0,0 & 0,1 & 0,1 \\ 0,0 & 0,0 & 0,1 & 0,1 \\ 0,0 & 0,0 & 0,1 & 0,1 \\ 0,0 & 0,0 & 0,1 & 0,1 \\ 0,0 & 0,0 & 0,1 & 0,1 \\ 0,0 & 0,0 & 0,0 & 0,1 \\ 0,0 & 0,0 & 0,0 & 0,0 \\ 0,0 & 0,0 & 0,0 & 0,0\end{array}$


